DOE/ORP-2000-19

Revision 0

\title{
Annual Summary of ILAW Performance Assessment
}

Prepared for the U.S. Department of Energy

Assistant Secretary for Environmental Management

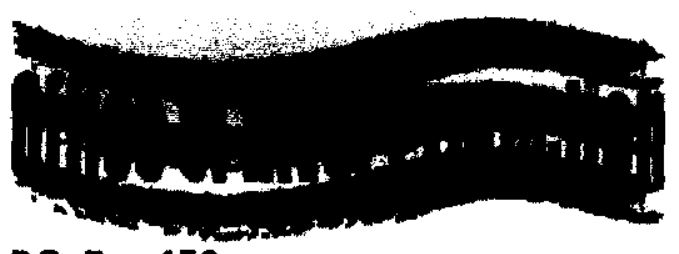

P.O. Box 450

Richland, Washington 99352 
DOE/ORP-2000-19

Revision 0

\title{
Annual Summary of ILAW Performance Assessment
}

\author{
F. M. Mann \\ Fluor Federal Services \\ R. J. Puigh \\ Fluor Federal Services
}

Date Published

May 2000

Prepared for the U.S. Department of Energy

Assistant Secretary for Environmental Management

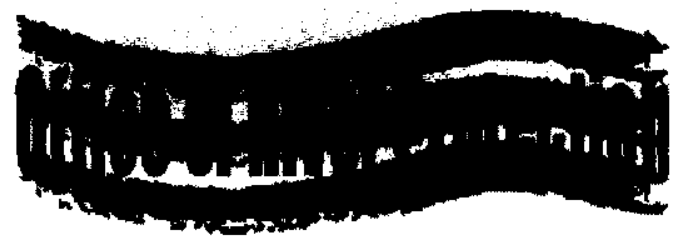

P.O. Box 450

Richland, Washington 99352 
LEGAL DISCLAIMER

This report was prepared as an account of work sponsored by an agency of the United States Government. Neither the United States GoverAment nor any agency thereof, nor any of their employees, nor any of their contractors, subcontractors or their employees, makes any warranty, express or implied, or assumes any legal liability or responsibility for the accuracy, completeness, or any third party's use or the results of such use of any information, apparatus, product, or process

disclosed, or represents that its use would not infringe privately owned rights. Reference herein to any specific commercial product, process, or service by trade name, trademark, manufacturer, or otherwise, does not necessarily constitute or imply its endorsement, recommendation, or favoring by the United States Government or any agency thereof or its contractors or subcontractors. The views and opinions of authors expressed herein do not necessarily state or reflect those of the United States Government or any agency thereof.

This report has been reproduced from the best available copy.

Printed in the United States of America 


\section{INFORMATION CLEARANCE FORM}

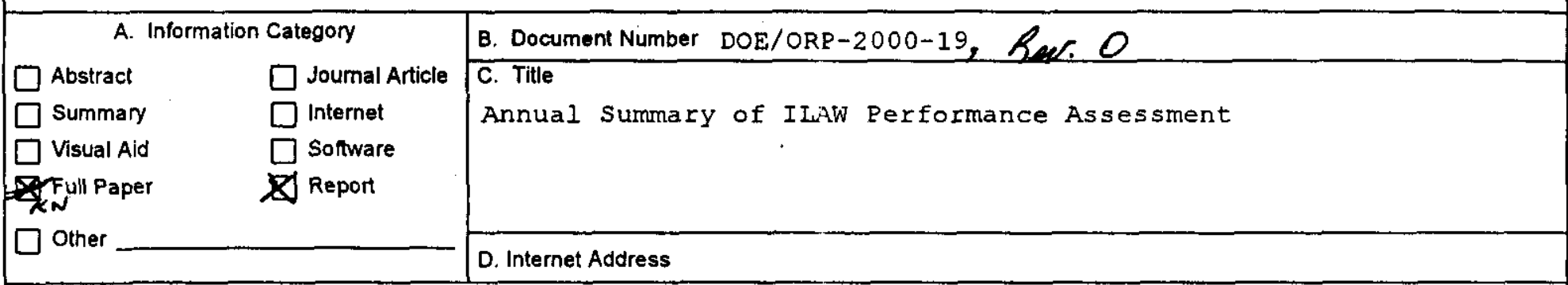

E. Required Information

1. Is document potentially Classified? $\square$ No $\square$ Yes (MANDATORY)

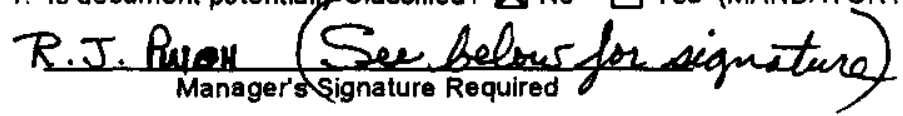

If Yes ADC Signature Required

$\square$ No $\square$ Yes Classified

2. Internal Review Required?

If Yes, Document Signatures Below

$\bigotimes$ No $\square$ Yes

Counsel

Program

3. References in the Information are Applied Technology $\bigotimes_{\text {No }} \square$ Yes Export Controlled Information $\bigotimes_{\text {No }} \square$ Yes
4. Does Information Contain the Following: (MANDATORY)

a. Now or Novel (Patentable) Subject Matter? $\square$ No $\square$ Yes If "Yos", Disclosure No.:

b. Information Received in Confidence, Such as Proprietary and/or Inventions? $\square$ No $\square$ Yes If "Yes", Affix Appropriate Legends/Notices.

c. Copyrights? $\bigotimes$ No $\square$ Yes If "Yes", Attach Permission.

d. Trademarks? $\square$ No $\square$ Yes If "Yes", Identify in Document.

5. Is Information requiring submission to OSTI? $\quad \square$ No $\square$ Yes

If Yes UCand $B \& R-$

6. Release Level? $\bigotimes$ Public $\square$ Limited

7. Charge Code 105867

1. Title of Journat $\mathrm{N} / \mathrm{A}$

\section{G. Complete for a Presentation}

1. Title for Conference or Meeting N/A

2. Group Sponsoring $N / A$

3. Date of Conference $N / A$

5. Will Information be Published in Proceedings? $\square$ No $\square$ Yes

4. City/State $\mathrm{N} / \mathrm{A}$

6. Will Material be Handed Out? $\square$ No $\square$ Yes

H. Author/Requestor

F.M. Mann (Print and Sign)

\begin{tabular}{lll}
\hline I. Reviewers Pes Print &
\end{tabular}

General Counsel

Office of External Affairs

DOE-PLORP

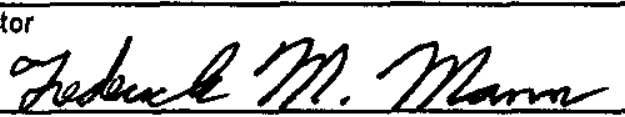

Yes Print

D

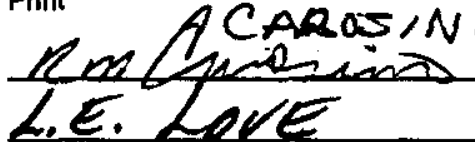

区

P.E.LaMont

Other

other- LMSI W

凶. R. W. Root H.G. NoLAN

\section{Responsible Manager}
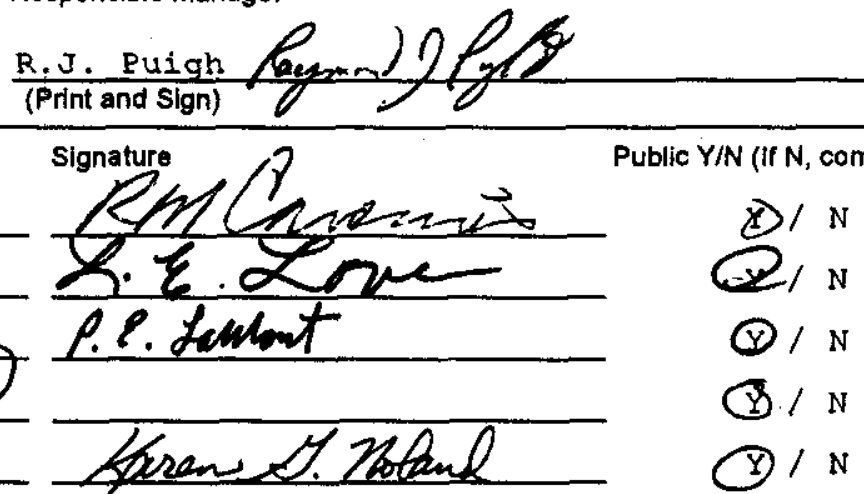

J. If Information Includes Sensitive Information and is not to be released to the Public indicate category below.

$\square$ Applied Technology $\square$ Protected CRADA

$\square$ Personal/Private $\square$ Export Controlled

$\square$ Proprietary

$\square$ Procurement-Sensitive

$\square$ Business-Sensltive

$\square$ Patentable

$\square$ Predecisional

$\square$ other (Specify)

$\square$ UCNI

K. If Additional Comments, Please Attach Separate Sheet

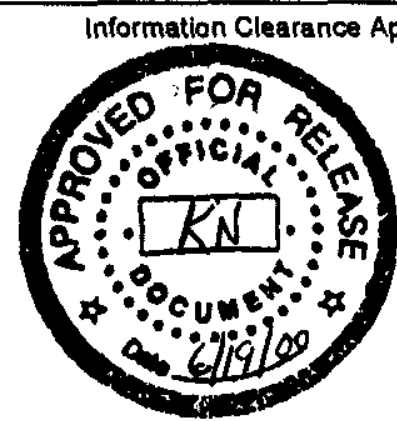




\section{RELEASE AUTHORIZATION}

Document DOE/ORP-2000-19, Revision 1

Number :

Document Annual summary of ILAW Performance Assessment Title:

This document, reviewed in accordance with DOE Order 241.1, "Scientific and Technical Information Management, "and 241.1-1, "Guide to the Management of Scientific and Technical Information," does not contain classified or sensitive unclassified information and is:

\section{APRROVED FOR PUBIIC RELEASE}

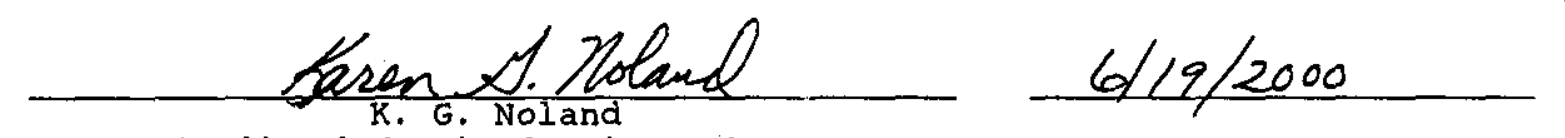

Lockheed Martin Services, Inc.

Document Control/Information Clearance

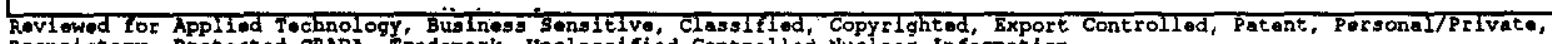
Proprietary, Protected CrADA, Trademark, Unclassified Controlled Nuclear information.

Irademark Disclaimer. Reference horoin to any specific commereiel product, process, or gervice by trade name, trademark, manufacturer, or otherw1se, doos not necessarily constitute or lmply its endorsomont, recomuendation, or favoring by the United States Government or any agency thoreof or lts contractors or subcontractors. The views and opinions of authors has been roproduced from the best available copy.

Printed in the United states of America.

Avallable to the U.S. Department of Energy and its contractors from the U.S. Department of Energy office of Scientific and Technlcal Information, P.0. Box 62, Oak Rldge, TH 37831; Telophene: 423/576-8101.

Avallable to the public from the U.s. Departmont of Commerce National Tochnical Information Service, 5285 port Royal Road, Apringtiold, VA 22161; Telephono: i03/187-4650. 


\section{Table of Contents}

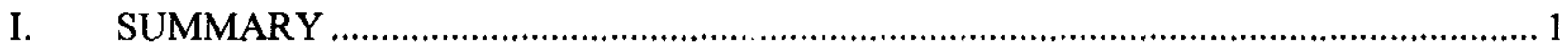

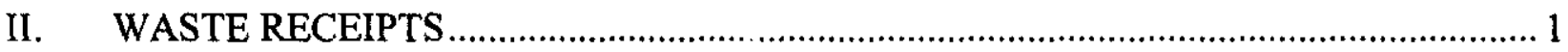

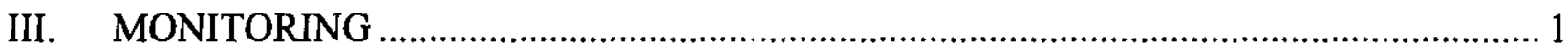

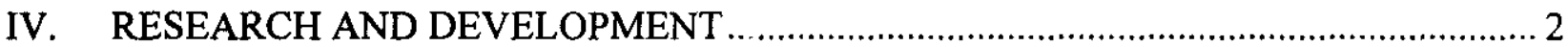

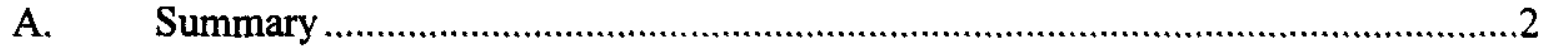

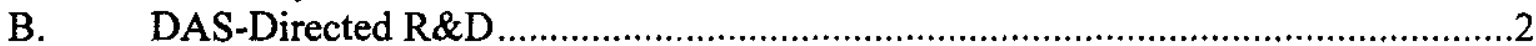

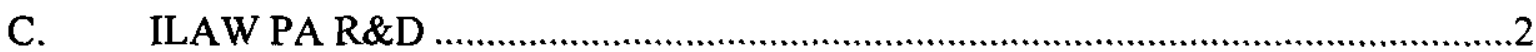

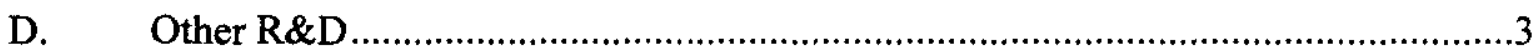

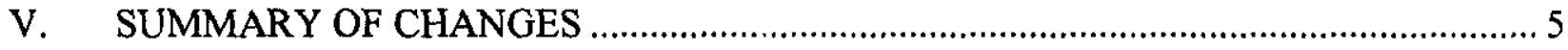

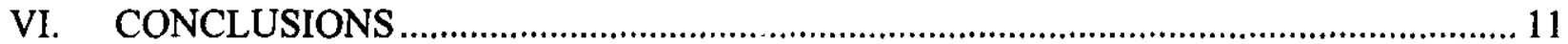

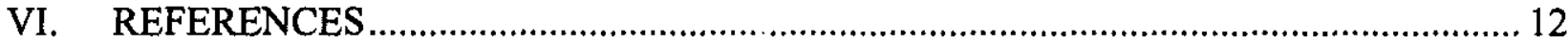

Appendix

A. WHITE PAPER UPDATING CONCLUSIONS OF 1998 ILAW PERFORMANCE ASSESSMENT (DOE/ORP-2000-07) …………………............................................

List of Figures

1. Comparison of Glass Corrosion Rate

List of Tables

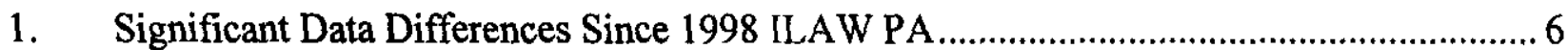

2. Comparison Of Estimated Impacts With Performance Objectives For A Time Of Compliance Of 1,000 Years .......................................................................................... 7

3. Effect of Updated Model Inputs on the Estimated Beta/Gamma Drinking Water Dose at 10,000 Years. 
DAS disposal authorization statement, equivalent of a license for disposing of radioactive wastes.

DOE Department of Energy

EMSP Environmental Management Science Program, a DOE organization supporting scientific research in cleaning up DOE sites.

EPA Environmental Protection Agency

ILAW immobilized low-activity tank waste

LFRG Low Level Waste Disposal Federal Review Group, DOE headquarters group which reviews PAs.

PA performance assessment

PCT product consistency test, a standardized glass test for measuring contaminant release under saturated conditions in a closed system

PUF pressurized unsaturated flow test, a glass test for measuring contaminant release under unsaturated hydraulic conditions

RCRA Resource, Conservation, and Recovery Act

R\&D research and development

SPFT single-pass flow through test, a glass test which measures the maximum rate of contaminant release

SUBCON Subsurface Focus Area, a DOE organization supporting technology development is the area of contaminants moving through the subsurface

TFA Tank Focus Area, a DOE organization supporting technology development in support of high-level waste

VHT vapor hydration test, an accelerated glass test for measuring the formation of secondary phases 


\section{SUMMARY}

As required by the Department of Energy (DOE) order on radioactive waste management (DOE 1999a) as implemented by the Maintenance Plan for the Hanford Immobilized Low-Activity Tank Waste Performance Assessment (Mann 2000a), an annual summary of the adequacy of the Hanford Immobilized Low-Activity Tank Waste Performance Assessment (ILAW PA) must be submitted to DOE headquarters each year that a performance assessment is not submitted. Considering the results of data collection and analysis, the conclusions of the 1998 version of the ILAW PA (Mann 1998) as conditionally approved (DOE 1999b) remain valid, but new information indicates more conservatism in the results than previously estimated. A white paper (Mann 2000b) is attached as Appendix A to justify this statement.

The format for this summary follows that required by the maintenance plan as directed by the DOE guidance on PA maintenance plans.

\section{WASTE RECEIPTS}

The facility is currently scheduled to become operational and receive the initial ILAW waste packages in 2007.

\section{MONITORING}

Since the disposal facility has not been constructed, pre-operational monitoring is being performed to establish a baseline. The Hanford Site has a groundwater-monitoring program, with the results for FY 1999 just released (Hartman 2000). Groundwater underneath of the proposed disposal facility has been impacted from previous discharges from Hanford Site operations, primarily liquid discharges to cribs associated with the PUREX plant. Although these cribs are down-gradient from the proposed disposal site, the plumes from these cribs spread up-gradient to underneath the disposal site due to the amount of material disposed in the cribs. The level of groundwater contamination for tritium is above drinking water standards $(20,000 \mathrm{pCi} /$ liter $)$ over some of the disposal site. Groundwater contamination from other materials (mainly ${ }^{129} \mathrm{I}$ and nitrate) are below drinking water standards.

Hanford Site records indicate no significant operational activities have been performed at the disposal site. Thus, no vadose zone contamination is expected and none has been found in the one ILAW borehole to date. 


\section{RESEARCH AND DEVELOPMENT}

\section{A. Summary}

Research and development (R\&D) for the ILAW PA is conducted in several programs. The ILAW PA activity directly funds selected research and development as documented in its annual update of its statement of work (Puigh 1999a). The ILAW program is also associated with the Hanford Groundwater / Vadose Zone Integration Project. As one of the "core projects" of the Hanford Groundwater / Vadose Zone Integration Project, the ILAW PA activity maintains close contacts with the Integration Project's Science and Technology activity as well as with EM-50 groups (the Environmental Management Science Program [EMSP], the Tank Focus Area [TFA], and the Subsurface Contamination Focus Area [SUBCON]). These other programs provide additional data and information that are directly utilized in developing a more complete understanding of the mechanisms that impact the ILAW disposal system performance.

\section{B. DAS-Directed R\&D}

No research and development activities were directly required by the facility's disposal authorization statement (DAS). However, the DAS did require that research on glasses be sent to the Low Level Waste Disposal Federal Review Group (LFRG). Such documentation has been sent (French 1999 and French 2000).

\section{ILAW PA R\&D}

The ILAW PA activity has sponsored many research and development activities. Only a few dealing with waste form performance and geology will be presented here.

Waste form performance is one of the important drivers in the ILAW PA. Substantial research and development effort has been pursued in this area. Before the ILAW PA program activities, the major glass tests were performed under saturated hydrologic conditions. Yet the moisture content expected in the disposal facility is only 5\%. Therefore, PNNL (McGrail) developed the pressurized unsaturated flow (PUF) test that can simulate and monitor the conditions in the disposal facility. Based on this effort, they were awarded Patent \#5974859, "Method and Apparatus for Measuring Coupled Flow and Reaction Processes" last year. Based on the work of Pete McGrail and his staff at the Pacific Northwest National Laboratory and Bill Ebert and his staff at the Argonne National Laboratory, the importance of the sodium-hydrogen ion exchange reaction is now acknowledged. Moreover, glass compositions developed by this team have led the way to better performing low-level radioactive waste glasses. In addition, by combining computer simulations with waste form measurements, a better understanding of how secondary glass phases influence the rate of glass dissolution and hence of long-term glass performance is obtained. 
Although thousands of boreholes have been drilled at the Hanford Site, few of these were designed to bring minimally disturbed vadose zone samples to the surface. The ILAW borehole was one of the first to do so. Based on the analysis of these samples, an important geologic unit was reinterpreted and new deposition timelines were established. For example, even though the last glacier floods were $\sim 13,000$ years ago, a significant depth of glacial deposited material has existed since the last flip of the magnetic poles $(770,000$ years ago).

Other research including moisture dependence of geochemical retardation, plant transpiration rates during winter months has also been supported by the ILAW PA activity. These efforts are expected to continue (Puigh 1999a).

\section{Other R\&D}

The ILAW PA program maintains important ties with TFA and EMSP efforts on glass performance and with EMSP and various Hanford Site efforts on site characterization.

As shown in the 1998 ILAW PA (Mann 1998) and the white paper (Mann 2000b), waste form performance is a major element driving the results. The immobilization team of the Tank Focus Area has been extremely supportive of the Hanford Site needs. TFA is sponsoring the testing of a large number of glasses to help determine the compositional space of acceptable glasses. The initial results of this multi-laboratory effort (Vienna 2000) document product consistency tests (PCT) and vapor hydration tests (VHT) are pointing to improved test methods and to glass composition areas to avoid. In addition, TFA sponsored an international panel of experts to review the approach of the ILAW PA team (McGrail 1998a) in estimating waste form performance over thousands of years based on short-term (few day to few year) laboratory data.

The Environmental Management Science Program is also supporting important research into glass performance. At higher temperatures, the breaking of Si bridging bonds is the rate-determining step. At temperatures corresponding to soil conditions and with high sodium content glasses, a second reaction (the ion exchange of hydrogen and sodium) becomes significant (McGrail 2000). The EMSP activity in this area has provided important data and understanding on how this formerly overlooked reaction affects glass dissolution.

In 1998, the ILAW PA activity drilled a borehole whose main purpose was to characterize the vadose zone. Based on the borehole data and the assumption that the disposal site is uncontaminated, several EMSP tasks are using the disposal site for field experiments. Moreover, at the kick-off meeting for principal investigators of FY99 EMSP subsurface awards, details of the ILAW site were described and many contacts established. In particular, the ground penetrating radar task of Rosemary Knight is being joined with ILAW-specific work to better characterize the disposal site as well as an 
adjoining site that will be used by the Science and Technology activity of the Hanford Groundwater / Vadose Zone Integration Project for research and development activities.

The major "core projects" prioritized science and technology needs. The major needs identified were

1) development and determination of long-term performance of surface barriers

2) development of remote sensing of contaminants $\left({ }^{99} \mathrm{Tc}\right.$, nitrates, uranium) in the subsurface

3) development and testing of materials that will chemically bind contaminants

4) improved understanding of long-determine recharge rates, and

5) improved understanding of moisture movement under arid conditions.

Interestingly, the first three of these are also major needs identified by a recent National Research Council panel on subsurface research needs (NRC 2000). 


\section{SUMMARY OF CHANGES}

The 1998 ILAW PA will be revised next year (2001). In preparation, data packages were developed and a limited number of analyses were conducted. This section outlines the changes to the information base, the consequences of the changed information base, and recommendations for the next performance assessment.

Reports were created in the following areas to document the data that will be used in the next performance assessment:

- $\quad$ Performance Objectives (Mann 1999a)

- $\quad$ Scenarios (Mann 1999b)

- $\quad$ Selection of a Waste Form Release Computer Code (McGrail 1998b)

- Verification of Selected Waste Form Release Code (Bacon 2000)

- Selection of a Vadose Zone Simulation Compute Code (Voogd 1999)

- Verification and Validation of Vadose Zone Code (Finfrock 2000)

- $\quad$ Geology (Reidel 1999)

- Inventory (Wootan 1999)

- $\quad$ Facility Data (Puigh 1999b)

- $\quad$ Recharge (Fayer 1999)

- $\quad$ Waste Form Release (McGrail 1999)

- $\quad$ Near-Field Hydrology (Meyer 1999)

- $\quad$ Far-Field Hydrology (Khaleel 1999)

- $\quad$ Geochemistry (Kaplan 1999)

- Dosimetry (Rittmann 1999)

- Future Potential Agricultural Uses of the Hanford Site (Evans 2000)

These documents are summarized and contained as appendices in Mann/Puigh 2000. In general, each of the above reports underwent multi-layered peer review. In almost all cases, this included peer review by experts outside of the Hanford Site.

There are many differences between these data packages and those used in the 1998 ILAW PA. The most important are contained in Table I and are described below. The impacts of these changes are analyzed in the White Paper Updating Conclusions of the 1998 ILAW Performance Assessment (Mann 2000b) which is included as Appendix A.

As in the 1998 ILAW PA, the performance objectives established in DOE orders as well as state and federal regulations were reviewed. The most important changes are those required by the new DOE order on radioactive waste management and by having the performance assessment activity support Resource, Conservation, and Recovery Act (RCRA) permitting activities. 
Table 1. Significant Data Differences Since 1998 ILAW PA

\begin{tabular}{|c|c|c|}
\hline Area & Difference & Impact \\
\hline $\begin{array}{l}\text { Performance } \\
\text { Objectives }\end{array}$ & $\begin{array}{l}\text { DOE O } 435.1 \text { requires a } 1,000 \text {-year time of } \\
\text { compliance. The analysis has continued } \\
\text { calculations out to } 20,000 \text { years as well as } \\
\text { introduced chemicals. }\end{array}$ & $\begin{array}{l}\text { At } 1,000 \text { years, there } \\
\text { is negligible impact to } \\
\text { the environment. } \\
\text { Chemicals are not } \\
\text { significant }\end{array}$ \\
\hline Scenarios & None & None \\
\hline Location & $\begin{array}{l}\text { All facilities will now be in the south central } \\
\text { part of the } 200 \text { East Area. Before, } 10 \% \text { of the } \\
\text { waste was to be disposed in the eastern part of } \\
\text { the } 200 \text { East Area. }\end{array}$ & $\begin{array}{l}\text { Much higher } \\
\text { groundwater dilution } \\
\text { at present site }\end{array}$ \\
\hline Facility Design & $\begin{array}{l}1998 \text { ILAW PA used underground concrete } \\
\text { vaults. Present baseline is trench disposal }\end{array}$ & $\begin{array}{l}\text { New design performs } \\
\text { better }\end{array}$ \\
\hline Inventory & $\begin{array}{l}\text { New data are based on current best inventory } \\
\text { of wastes in tanks and newer data on } \\
\text { separations between high-level and low- } \\
\text { activity fraction of wastes. New (longer) } \\
\text { values for the half-life of }{ }^{79} \mathrm{Se} \text { and }{ }^{126} \mathrm{Sn} \text { were } \\
\text { used. }\end{array}$ & $\begin{array}{l}\text { Overall, lower } \\
\text { impact. } \\
\text { Contributions from } \\
\text { some contaminants } \\
\text { increased. }\end{array}$ \\
\hline Waste Form & $\begin{array}{l}\text { Greater expanded data base, particularly on } \\
\text { waste forms private vendor is likely to } \\
\text { produce }\end{array}$ & $\begin{array}{l}\text { Expected lower } \\
\text { impact. Calculations } \\
\text { presently only } \\
\text { available for forward } \\
\text { rate reactions. }\end{array}$ \\
\hline Recharge & $\begin{array}{l}\text { Based on surface soils, two natural recharge } \\
\text { rates are expected ( } 4.2 \mathrm{~mm} / \mathrm{yr} \text { and } 0.9 \mathrm{~mm} / \mathrm{yr}) \\
\text { which bracket value used in } 1998(3 \mathrm{~mm} / \mathrm{yr})\end{array}$ & Little \\
\hline Geology & $\begin{array}{l}\text { Better understanding of geologic units based } \\
\text { on site-specific data }\end{array}$ & Little \\
\hline Hydrology & Have site-specific data & Little \\
\hline Geochemistry & $\begin{array}{l}\text { Have site-specific data (Kd for Se increased } \\
\text { from } 0 \text { to } 3 \mathrm{ml} / \mathrm{g} ; \mathrm{Kd} \text { for I decreased from } 3 \text { to } \\
0 \text {, and } \mathrm{Np} \text { decreased from } 15 \text { to } 0.6 \text { ). } \\
\text { Additional information on other features. }\end{array}$ & $\begin{array}{l}\text { Little overall. Se } \\
\text { becomes less } \\
\text { important, I and } \mathrm{Np} \\
\text { become more } \\
\text { important }\end{array}$ \\
\hline $\begin{array}{l}\text { Groundwater } \\
\text { transport }\end{array}$ & Used the Hanford Site Groundwater Model & $\begin{array}{l}\text { Little because of } \\
\text { model change. }\end{array}$ \\
\hline Dosimetry & $\begin{array}{l}\text { Now using EPA conversion coefficients. } \\
\text { Made intruder parameters more conservative. }\end{array}$ & $\begin{array}{l}\text { Little on groundwater } \\
\text { scenarios. Increased } \\
\text { intruder results are } \\
\text { balanced by lower } \\
\text { inventories. }\end{array}$ \\
\hline
\end{tabular}


The 1998 ILAW PA used a time of compliance of 10,000 years based on the requirement that the Nuclear Regulatory Commission (NRC) must determine whether ILAW is incidental waste. Since then, DOE O 435.1 (DOE 1999a) has defined the time of compliance for performance assessments to be 1,000 years. Current evaluations now use this shorter time, while still performing calculations to later times to maintain consistency and to provide the NRC with information. Because the average travel time for the thick vadose zone under the arid conditions of the Hanford Site is about 1,200 years, this shortening of the time of compliance greatly reduces the impact of ILAW disposal. For example, the all-pathways dose for time periods of less than 1,000 years is a factor of 100 times smaller than for times less than 10,000 years. Alpha-emitters (such as uranium and neptunium) do not even reach groundwater in 1,000 years. A comparison of the results from the latest analysis to the performance objectives is shown in Table 2.

Table 2. Comparison of estimated impacts with performance objectives for a time of compliance of 1,000 years.

\begin{tabular}{|l|l|l|}
\hline Performance Measure & $\begin{array}{l}\text { Performance } \\
\text { Objective }\end{array}$ & $\begin{array}{l}\text { Estimated Impact } \\
\text { at } 1,000 \mathrm{y}\end{array}$ \\
\hline All-pathways [mrem in a y] & 25.0 & 0.0061 \\
\hline Drinking Water & \multicolumn{2}{|l|}{} \\
\hline Beta/photon emitters [mrem in a y] & 4.0 & 0.0017 \\
\hline Alpha emitters [pCi/L] & 15.0 & $4.2 \times 10^{-14}$ \\
\hline Radium [pCi/L] & 5.0 & 0.0 \\
\hline Surface waters & 1.0 & \\
\hline Beta/photon emitters [mrem in a y] & 15.0 & $1.4 \times 10^{-4}$ \\
\hline Alpha emitters [pCi/L] & 0.3 & $6.8 \times 10^{-16}$ \\
\hline Radium [pCi/L] & 0.0 \\
\hline
\end{tabular}

Because, ILAW will contain hazardous waste, it must be managed under the requirements of RCRA. The Washington State Department of Ecology has requested that the supporting information for the RCRA permits for disposal be based on the same information and analyses as for regulation under the Atomic Energy Act (i.e., DOE orders). Therefore, performance objectives have been established for chemicals as well as radionuclides. The analysis shows that the impacts from chemicals are far lower (by many orders of magnitude) than the impacts of the radionuclides.

The scenarios remain unchanged from the 1998 ILAW PA. However, many parameters have changed. These are discussed below.

The 1998 ILAW PA assumed that all of the facilities holding the waste would be underground concrete vaults, somewhat similar to those constructed for disposal of the tank waste as a grout waste form. In 1999, the Office of River Protection (Taylor 1999) decided that trenches similar to those currently being used for Hanford Site mixed waste disposal would cost less and would accelerate schedules. At the time, the environmental impact was thought to be small. The white paper in appendix A actually shows that trench disposal is actually more protective of the environment, by a factor of about 2 . 
The reason for this reduction is that as the concrete vaults degrade, the $\mathrm{pH}$ of the pore water passing through the degraded structure increases. Such an increase in $\mathrm{pH}$ greatly increases the release rate of the contaminants from the glass waste form. In addition, the ratio of ILAW packages to soil is lower in the trench concept, which allows the soil to have a greater $\mathrm{pH}$ buffering effect that again lowers the contaminant release rate.

The 1998 ILAW PA assumed that a Hanford Barrier would be used as the surface barrier. This barrier has a design life of 1,000 years. Given the material resources required for the Hanford barrier, most disposal projects at Hanford are now moving away from the Hanford Barrier. The current plan is to use a modified RCRA C Barrier, which has a design life of 500 years. There is little environmental impact with this change.

In general, the inventory of materials in the tanks has not greatly changed. However, what has changed is the separation of the tank wastes into the two waste streams (low-activity and high-level), some half-life information, and which contaminants are now thought important. The 1998 ILAW PA showed that ${ }^{99} \mathrm{Tc}$ was by far the most important contaminant for water scenarios (followed by ${ }^{79} \mathrm{Se}$ ), and ${ }^{126} \mathrm{Sn}$ was the most important for intruder scenarios. The present plan is to limit the amount of ${ }^{99} \mathrm{Tc}$ in ILAW to $20 \%$ of the tank inventory, the rest going to the high-level stream. The halflife of ${ }^{79} \mathrm{Se}$ has now been measured multiple times to be much longer than previously believed. In combination with site-specific geochemical measurements that show that $\mathrm{Se}$ is retarded in Hanford soils, ${ }^{79} \mathrm{Se}$ is now considered unimportant. Similarly, the half-life of ${ }^{126} \mathrm{~S} n$ has also been found to be much longer. This reduces its contribution. As will be discussed below in geochemistry, iodine and neptunium are much more mobile in Hanford soils than previously thought and hence their importance increases.

The base analysis case of the 1998 ILAW PA was based on the specifications of the request for proposal with a sensitivity case modeling LD6-5412 glass, a borosilicate glass. Subsequent to the issuance of the PA, BNFL, Inc. announced that they were going to use a glass of significantly different composition. The performance assessment activity ran a large series of tests (short- and long-term product consistency tests [PCT], pressurized unsaturated flow tests [PUF], single-pass flow through tests [SPFT], and vapor hydration tests [VHT]) on BNFL, Inc. and similar glasses. Special emphasis was placed on LAWABP1, a glass composition developed by the Pacific Northwest National Laboratory based on proprietary BNFL, Inc. compositions. At the current time, only calculations using the fastest rate of glass dissolution (that is, the forward rate) have been done. The results of these calculations show that the fastest rate of release of LAWABP1 is only 3.6 times faster than the constant release rate assumed in the 1998 ILAW PA. Based on relative performance between LAWABP1 and LD6-5412 (see, for example, Figure 6.4 of Appendix A, reproduced below as Figure 1), the expected long-term release rate of the new glasses will be far better than analyzed in the 1998 ILAW PA. 
Figure 1. Comparison of Glass Corrosion Rate in PUF Tests at $99^{\circ} \mathrm{C}$ and VHT Tests at $200^{\circ} \mathrm{C}$.

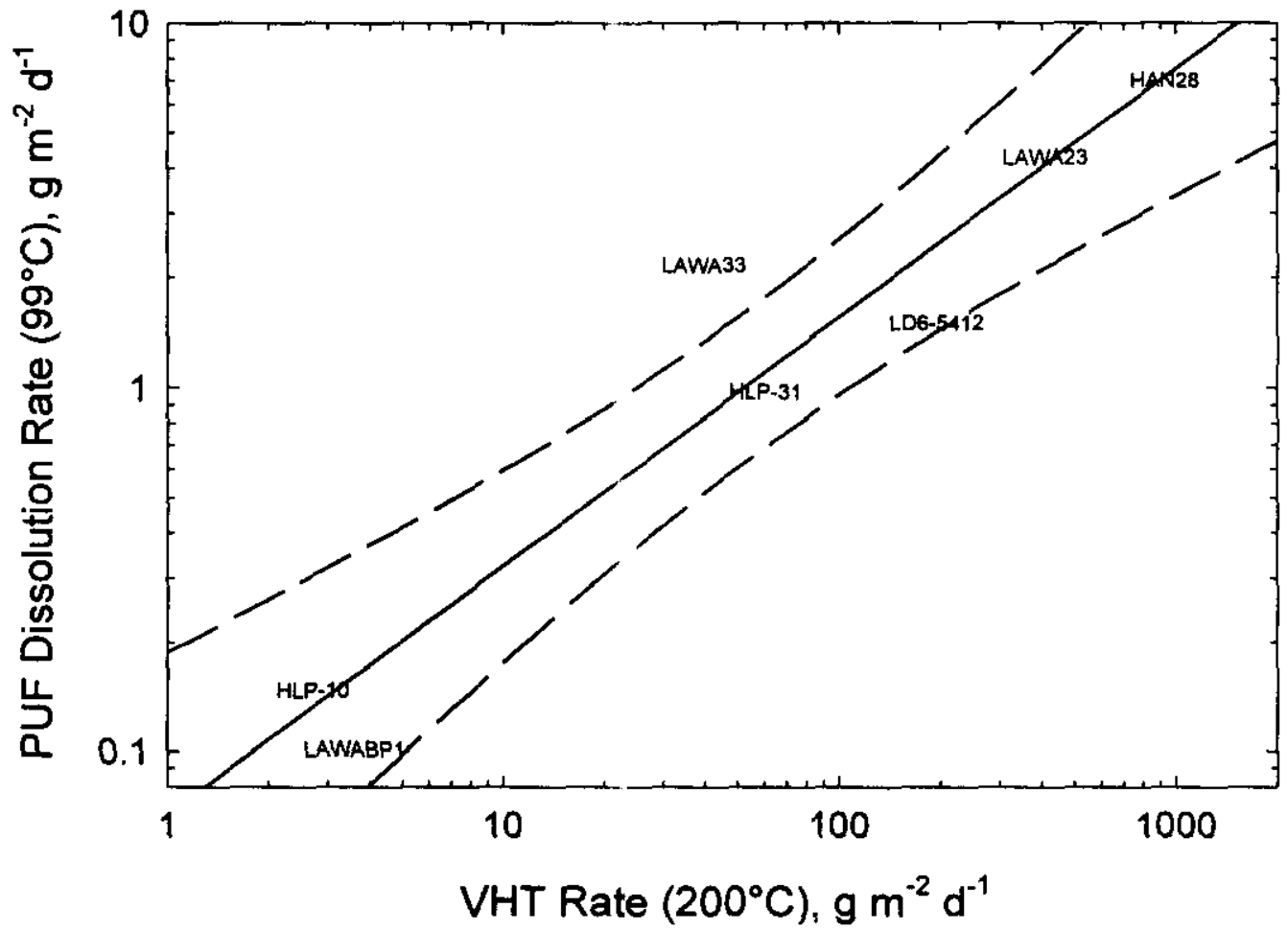

In addition, the Tank Focus Area ran short-term PCT and VHT measurements on 55 glasses (Vienna 2000). As seen in the discussion in section 6.3 of Appendix A, there now exist many glasses of excellent quality. LAWABP1 is in the middle of these glasses and hence is representative of the performance expected of the waste form.

Based on non-site specific data for the 200 East Area, the 1998 ILAW PA used a long-term natural recharge rate of $3 \mathrm{~mm} /$ year with a 1,000 year infiltration rate through a surface barrier of $0.5 \mathrm{~mm} / \mathrm{yr}$. It has been long known that surface soils affect the amount of recharge. Based on site specific data, the northern part of the disposal area is expected to have a recharge rate of $4.2 \mathrm{~mm} / \mathrm{yr}$, while the southern part will have a recharge rate of $0.9 \mathrm{~mm} / \mathrm{yr}$. In addition, based on lysimetry measurements and simulations, barrier performance is now expected to be better, yielding only $0.1 \mathrm{~mm} / \mathrm{yr}$. There is relatively little impact from these changes.

The geology used in the 1998 ILAW PA was based on boreholes in the eastern part of the 200 East Area, which is typical of the 200 East Area. Since then, a new highquality borehole has been placed in the area of the disposal site and data from old boreholes near the disposal site have been reinvestigated. It is now realized that the disposal site is squarely over the old channel of the Columbia River. Thus, the hydraulic conductivity (and hence groundwater flow) is much higher in this region than is true in general for the 200 East Area, resulting in lower contaminant groundwater concentrations. In addition, it is now realized that the lower Hanford gravel unit is 
unconsolidated gravels, where previously more fines were expected to be present. This new understanding has little impact on the PA results, since the mobility of contaminants is controlled by the recharge rate rather than the hydraulic properties of this layer.

Many high-quality vadose zone samples were taken from the new borehole. Many hydraulic measurements were taken on these samples, significantly increasing the general Hanford Site hydraulic database. In addition, correlations between samples were measured. However, the impacts of these changes are small.

Samples from the new borehole were also investigated for their geochemical properties as well as their joint hydraulic/geochemical properties. Also, non-borehole samples provided a greater understanding of other geochemical areas. The major changes from the 1998 ILAW PA were the changes in the mobility of 3 key contaminants, Se, I, and Np. In the 1998 ILAW PA, Se was assumed to move with water, but new measurements showed that it is significantly retarded. On the other hand, site-specific measurements for the retardation of I and $\mathrm{Np}$ show greater mobility because of the lack of certain key minerals at the disposal site. Overall, there is a slight increase in impact.

The 1998 ILAW PA used the Hanford site groundwater model developed by the Hanford Site Environmental Restoration Contractor. Since then, the site has gone to another model developed by the Pacific Northwest National Laboratory. The impact of changing models on the results was small. The bigger change was the inclusion of the old channel of the Columbia River into the new model, which reduced impacts by about a factor of 10 .

A series of mostly minor changes have occurred in dosimetry parameters since the 1998 ILAW PA. The current analysis now uses the Environmental Protection Agency (EPA) dose conversion factors, while the 1998 ILAW PA used a mixture of the EPA and DOE. There is little impact from this change. A bigger impact results from reducing the size of the garden in the inadvertent intruder scenario from 2,000 to 200 square feet. Such a reduction places the inadvertent intruder closer to larger amounts of contamination. However, when the reduction in the ${ }^{126} \mathrm{Sn}$ inventory and the smaller height of the waste containers are also included in the calculation, the overall impact was negligible.

In summary, the overall change in the groundwater scenarios from the 1998 ILAW PA result in a lower estimation of impacts. Table 3 summarizes the results of the most important changes. The results for the inadvertent intruder are basically the same as for the 1998 ILAW PA. 
Table 3. Effect of Updated Model Inputs on the Estimated Beta/Gamma Drinking Water Dose at 10,000 Years. (1998 ILAW PA estimated this dose as $2.0 \mathrm{mrem} / \mathrm{y}$ )

\begin{tabular}{|l|r|r|}
\hline Updated Model Input & \multicolumn{2}{|c|}{ Beta/Gamma Drinking Water Dose } \\
\cline { 2 - 3 } & White Paper (mrem/y) & Ratio to 1998 ILAW PA \\
\hline Facility Design & 1.18 & 0.59 \\
\hline Tc Inventory & 0.52 & 0.26 \\
\hline Other Mobile Contaminants (1) & 3.16 & 1.58 \\
\hline Waste Form Release Rate & 7.20 & 3.6 \\
\hline Groundwater Dilution & 0.196 & 0.098 \\
\hline All Inputs & 0.170 & 0.085 \\
\hline
\end{tabular}

(1) based on updated $\mathrm{K}_{d}$ values for $\mathrm{Se}$, I, and $\mathrm{Np}$.

\section{CONCLUSIONS}

Recent ILAW performance estimates used on the waste form and geochemical data have resulted in increased confidence that the disposal of ILAW will meet performance objectives.

The ILAW performance assessment program will continue to interact with science and technology activities, disposal facility design staff, and operations, as well as to continue to collect new waste form and disposal system data to further increase the understanding of the impacts of the disposal of ILAW. The next full performance assessment should be issued in the spring of 2001 . 


\section{REFERENCES}

Bacon 2000, D.H. Bacon, M.D. White, and B.P. McGrail, Subsurface Transport Over Reactive Multiphases (STORM): A General, Coupled Nonisothermal Multiphase Flow, Reactive Transport, and Porous Medium Alteration Simulator, Version2, User's Guide, PNNL-13108, Pacific Northwest National Laboratory, February 2000.

DOE 1999a, "Radioactive Waste Management", DOE O 435.1, U.S. Department of Energy, Washington, D.C., July 9, 1999. This order is implemented in Manual for DOE O 435. I", DOE M 435.1, U.S. Department of Energy, Washington, D.C., July 9, 1999.

1. Performance assessment requirements are presented in Chapter IV (LowLevel Waste), section P (disposal).

DOE 1999b, "Conditional Acceptance of the Immobilized Low-Activity Tank Waste Disposal Facility Performance Assessment and the Hanford Site 200 Plateau Composite Analysis", Memorandum from James J. Fiore and Mark W. Frei to Richard French and Keith A. Klein, U.S. Department of Energy, Washington, D.C., October 20, 1999.

Evans 2000, R.G. Evans, M.J. Hattendorf, and C.T. Kincaid, Evaluation of the Potential for Agricultural Development at the Hanford Site, PNNL-13125, Pacific Northwest National Laboratory, Richland, Washington, January 2000. This work was performed by the Washington State University.

Fayer 1999, M.J. Fayer, Recharge Data Package for the Immobilized Low-Activity Waste 2001 Performance Assessment, PNNL-13033, Pacific Northwest National Laboratory, Richland, Washington, December 1999. Also Appendix J of Mann/Puigh 2000.

Finfrock 2000, S.H. Finfrock, Verification and Validation for VAM3DF, Version 1.00 (FFS Version 1.00), HNF-5769, Rev. 0, Fluor Federal Services, Richland, Washington, January 2000.

French 1999, R.T. French, "Disposal Authorization for the Hanford Site Low-Level Waste Disposal Activities", memorandum to Mark W. Frei, 99-DPD-071, Office of River Protection, U.S. Department of Energy, Richland, Washington, December 29, 1999.

French 2000, R.T. French, "Initial Data Package from the Tank Focus Area on 55 Test Glasses for Hanford Immobilized Low-Activity Waste (ILAW) Studies," memorandum to Mark W. Frei, 00-DPD-018, Office of River Protection, U.S. Department of Energy, Richland, Washington, March 10, 2000. 
Hartman 2000, M.J. Hartman, L.F. Morasch, and W.D. Webber (editors), Hanford Site Groundwater Monitoring for Fiscal Year 1999, PNNL-13116, Pacific Northwest National Laboratory, Richland, Washington, March 2000.

Kaplan 1999, D.L. Kaplan And R.J. Serne, Geochemical Data Package For The Immobilized Low-Activity Waste Performance Assessment, PNNL - 13037, Pacific Northwest National Laboratory, Richland, Washington, December 1999. Also Appendix N of Mann/Puigh 2000.

Khaleel 1999, R. Khaleel, Far-Field Hydrology Data Package For The Immobilized Low-Activity Waste Performance Assessment, HNF-4769, Rev. 2, Fluor Federal Services, Richland, Washington, December 1999. Also Appendix M of Mann/Puigh 2000.

Mann 1998, F. M. Mann, R. J. Puigh II, P. D. Rittmann, N. W. Kline, J. A. Voogd, Y. Chen, C. R. Eiholzer, C. T. Kincaid, B. P. McGrail, A.H. Lu, G.F. Williamson, N. R. Brown, and P. E. LaMont, Hanford Immobilized Low-Activity Tank Waste Performance Assessment, DOE/RL-97-69, Rev. 0, U.S. Department of Energy, Richland, Washington, March 1998.

Mann 1999a, F. M. Mann, Performance Objectives for the Hanford Immobilized LowActivity Waste (ILAW) Performance Assessment, HNF-EP-0826, Revision 3, Fluor Daniel Northwest, Inc., Richland, Washington August 1999. Also Appendix A of Mann/Puigh 2000.

Mann 1999b, Scenarios for the Hanford Immobilized Low-Activity Waste (ILAW) Performance Assessment, HNF-EP-0828, Rev. 3, Lockheed Martin Hanford Company, Richland, Washington, August 1999. Also Appendix B of Mann/Puigh 2000 .

Mann 2000a, F.M. Mann, Maintenance Plan for the Hanford Immobilized Low-Activity Tank Waste Performance Assessment, DOE/ORP-2000-01, Rev. 0, Department of Energy, Office of River Protection, Richland, Washington, February 2000. This plan was formally by the ORP Field Manager in a memorandum to Mark W. Frei (Office of Projection Completion), Department of Energy) dated March 7, 2000, 00-DPD-015.

Mann 2000b, F.M. Mann, S.H. Finfrock, E.J. Freeman, R.J. Puigh II, D.H. Bacon, M.P. Bergeron, B.P. McGrail, and S.K. Wurstner, White Paper Updating the Conclusions of 1998 ILAW Performance Assessment, DOE/ORP-2000-07, Office of River Protection, Department of Energy, Richland, Washington, April 2000.

Mann/Puigh 2000, F. M. Mann and R. J. Puigh II, Data Packages for the Hanford Immobilized Low-Activity Tank Waste Performance Assessment: 2001 Version, HNF-5636, Fluor Federal Services, Richland, Washington, February 2000. 
McGrail 1998a, B. P. McGrail, W. L. Ebert, D. H. Bacon, and D. M. Strachan. $A$ Strategy to Conduct an Analysis of the Long-Term Performance of Low-Activity Waste Glass in a Shallow Subsurface Disposal System at Hanford, PNNL-11834, Pacific Northwest National Laboratory, Richland, Washington.

McGrail 1998b, B. P. McGrail and D. H. Bacon, Selection Of A Computer Code For Hanford Low-Level Waste Engineered-System Performance Assessment, PNNL10830 Rev. 1, Pacific Northwest National Laboratory, Richland, Washington, March 1998.

McGrail 1999, B. P. McGrail, D. H. Bacon, J. P. Icenhower, W. L. Ebert, P. F. Martin, H. T. Schaef, and E. A. Rodriguez, Waste Form Release Data Package for the 2001 Immobilized Low-Activity Waste Performance Assessment, PNNL-13043, Pacific Northwest National Laboratory, Richland, Washington, December 1999. Also Appendix K of Mann/Puigh 2000.

McGrail 2000, B. P. McGrail, J. P. Icenhower, D. K. Shuh, J. G. Darab, D. R. Baer, S. Thevuthasen, V. Shutthanandan, and M.H. Englehard. 2000. "The Structure of $\mathrm{Na}_{2} \mathrm{O}-\mathrm{Al}_{2} \mathrm{O}_{3}-\mathrm{SiO}_{2}$ Glasses and Its Impact on Sodium Ion Exchange in $\mathrm{H}_{2} \mathrm{O}, \mathrm{D}_{2} \mathrm{O}$, and $\mathrm{D}_{2}{ }^{18} \mathrm{O}$. Submitted to J. Non-Cryst. Solids.

Meyer 1999, P. D. Meyer and R. J. Serne, Near Field Hydrology Data Package for the Immobilized Low-Activity Waste 2001 Performance Assessment, PNNL-13035, Revision 1, Pacific Northwest National Laboratory, Richland, Washington, December 1999. Also Appendix L of Mann/Puigh 2000.

NRC 2000, National Research Council, Research Needs in Subsurface Science, National Academy Press, Washington, D.C., 2000.

Puigh 1999a, R.J. Puigh II and F.M. Mann, Statements of Work for FY2000 to 2005 for the Hanford Low-Activity Tank Waste Performance Assessment Program, HNFSD-WM-PAP-062, Rev. 4, Lockheed Martin Hanford Corporation, July 1999.

Puigh 1999b, R. J. Puigh II, Disposal Facility Data for the Hanford Immobilized LowActivity Tank Waste, HNF-4950, Rev. 1, Fluor Federal Services, Richland, Washington, December 1999. Also Appendix I of Mann/Puigh 2000.

Reidel 1999, S. P. Reidel and D. G. Horton, Geologic Data Packages for 2001 Immobilized Low-Activity Waste Performance Assessment, PNNL-12257, Rev. 2, Pacific Northwest National Laboratory, Richland, Washington, December 1999. Also Appendix G of Mann/Puigh 2000.

Rittmann 1999, P. D. Rittmann, Exposure Scenarios And Unit Dose Factors For The Hanford Immobilized Low-Activity Tank Waste Performance Assessment, HNFSD-WM-TI-707, Rev. 1, Fluor Federal Services, Richland, Washington, December 1999. Also Appendix O of Mann/Puigh 2000. 
Taylor 1999, W. J. Taylor, Contract No. DE-AC06-99RL14047 - Decision to Change the Immobilized Low-Activity Waste (ILAW) Disposal Baseline to Proceed with the Remote-Handled Trench Alternative, letter 99-DPD-066 (correspondence control number 9958849), Department of Energy, Richland, Washington, December 1, 1999.

Vienna 2000, J.D. Vienna, A. Jircka, B.P. McGrail, B.M. Jorgensen, D.E. Smith, B.R. Allen, J.C. Marra, D.K. Peeler, K.G. Brown, I.A. Reamer, and W.L. Ebert, Hanford Immobilized LAW Product Acceptance: Initial Tank Focus Area Testing Package, PNNL-13101, Pacific Northwest National Laboratory, Richland, Washington, February 2000.

Voogd 1999, J. A. Voogd, F. M. Mann, and A. J. Knepp, Recommendations for Computer Code Selection of a Flow and Transport Code to be Used in Undisturbed Vadose Zone Calculations for TWRS Immobilized Wastes, HNF4356, Lockheed Martin Hanford Corporation, Inc., April 1999.

Wootan 1999, D. W. Wootan, Immobilized Low Activity Tank Waste Inventory Data Package, HNF-4921, Rev. 0, Fluor Daniel Northwest, Inc., September 1999. Also appendix $\mathrm{H}$ of Mann/Puigh 2000. 
DOE/ORP-2000-19, REV. 0

This page intentionally left blank 
DOEKRP+2000-19, REV.0

DOE/ORP-2000-07, REV. 0

Appendix A

\section{WHITE PAPER \\ UPDATING CONCLUSIONS OF 1998 \\ ILAW \\ PERFORMANCE ASSESSMENT}

F.M. Mann ${ }^{1}$, R.J. Puigh $\mathrm{II}^{1}$, E.J. Freeman
Bacon
, S.H. M.P. Bergeron

April, 2000

Fluor Federal Services, P.O. Box 1050, Richland, Washington

Pacific Northwest National Laboratory, P.O. Box 999, Richland, Washington 
DOE/ORP-2000-19, Revision 0

Reference: DOE/ORP-2000-07

Revision 0

\section{WHITE PAPER \\ UPDATING CONCLUSIONS OF 1998 ILAW PERFORMANCE ASSESSMENT}

F. M. Mann

Fluor Federal Services

S. H. Finfrock

E. J. Freeman

R. J. Puigh II

Fluor Federal Services

D. H. Bacon

M. P. Bergeron

B. P. McGrail

S. K. Wurstner

Pacific Northweat National Laboratory

Date Published

April 2000

Prepared for the U.S. Department of Energy

Assistant Secretary for Environmental Management

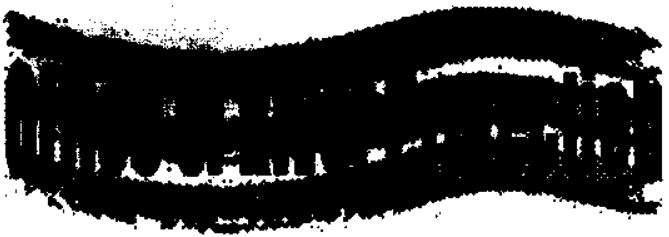

P.O. Bon 480

Aichland, Washington 99352 
This report wes prepered es an ecooum of work sponeorad by en agency of the Unilied states Govemmint. Nelliner the United state Governinent nor any egenty thereot, nor any of thelr employese, nor any of their contrectipe, subcontractors or their employees, makes any werrarty, os preses or impliod, of

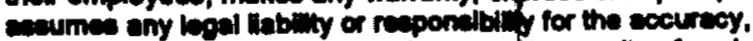
complatenes, or any third pertys une of the resulis of ewch une of any information, eppartis, prodult, or proceses

cincloesed, or repreasitis that lis vise worly not infitinge privately owned itots. Reference herein to any becific commencled product, proceses, or servios by trede nayse, tredemark, mienufecturex, or othenwite, does not ned wicarthy conethute or inply the endoresement, recommendetion, or favoring by the United state covernment of any eaeno thereof of the contructors or eubeontructors. The vinim and opinions of euthore expreseed herein do not moevendry etate or refiect thoes of the United stetes Covemment of any arency thereof.

This report hes been reproduced from the beat avallable copy. 


\section{RELEASE AUTHORIZATION}

Document DOEJORP-2000-07, Rev. 0

Number:

Document THte: White Paper Updating Conclusions of 1998 ILAW Performance Assessment

\section{This document, reviewed in accordance with DOE Order 241.1, "Scientific and Technical Information Management," and DOE G 241.1-1, "Guide to the Management of Sclentific and Technical information," does not contain classified or sensitive unclassified information and is:}

\section{APPROVED FOR PUBLIC RELEASE}

\section{Chistivic Ytillengend \\ C. Willinginem \\ Lockheod Mertin Services, Inc. \\ Document Controlinformation Charance}

$5 / 11 / 100$

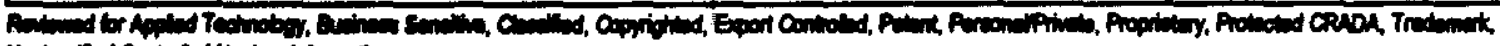

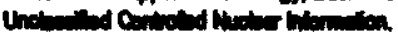

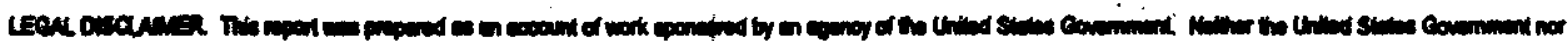

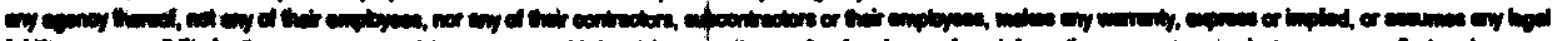

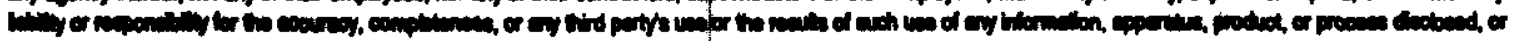

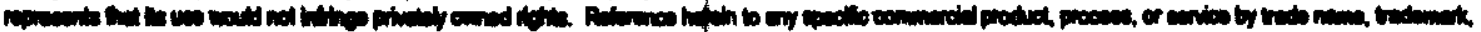

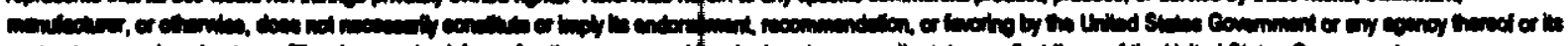

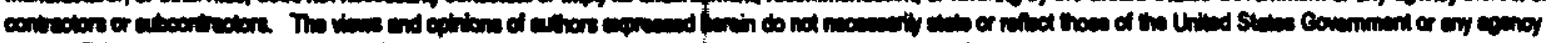

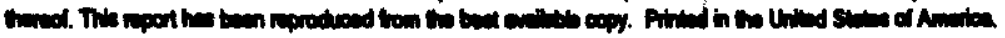




\section{WHITE PAPER \\ UPDATING CONCLUSIONS OF 1998 ILAW PERFORMANCE ASSESSMENT}

April 2000

Pepared by:

Prepared by:

Prepared by:

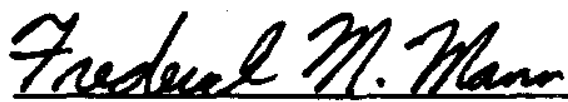

F.M. Mann

R.p. 11 Puigh If

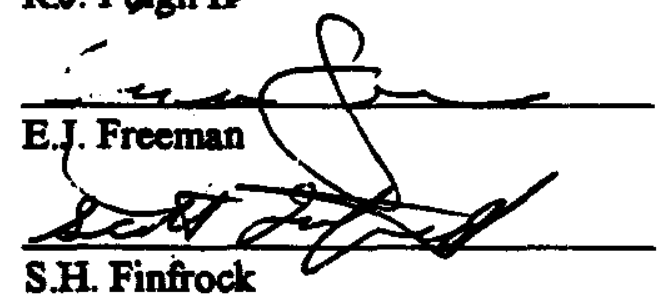

Prepared by: $\frac{D_{\text {Uara }} * \text { B Becou }}{\text { D.H. Bacon }}$

Prepared by: $\frac{\text { WPR herger }}{\text { M.P. Bergeron }}$

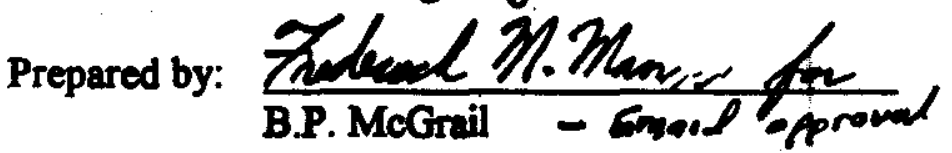

Prepared by: $\frac{\text { SigmeK. Wunothut }}{\text { S.K. Wurtner }}$

Reviewed by:

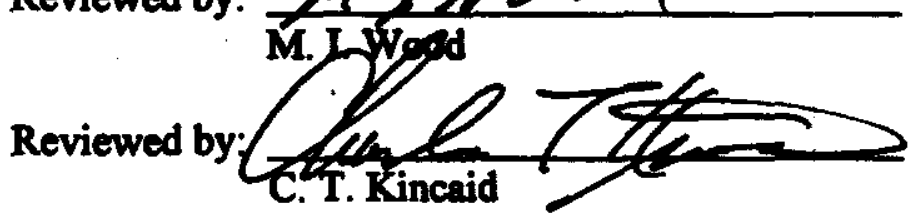

Date: $4 / 24 / 00$

Date: $4 / 24 / 00$

Date: $4 / 24 / 00$

Date: $4 / 34 / 60$

Date: $4-24-00$

Date: $4-24-00$

Date: $4 / 24100$

Date: $4 / 2+13000$

Date: $y / 24 / 00$

Date: $4 / 24 / 100$. 


\section{WHITE PAPER \\ UPDATING CONCLUSIONS OF 1998 ILAW PERFORMANCE ASSESSMENT}

F.M. Mann ${ }^{1}$, R.J. Puigh $\Pi^{1}$, E.J. Freeman ${ }^{1}$, S.H. Finfrock', D.H. Bacon', M.P. Bergeron ${ }^{2}$, B.P. MeGrail', and S.K. Wurstner ${ }^{2}$

April, 2000

1 Fluor Federal Services, P.O. Bax 1050, Richland, Washington

2 Pacific Northwest National Leberwery, P.O. Box 999, Richland, Washington 
DOE/ORP-2000-19, REV. 0

Reference: DOE/ORP-2000-07, REV. 0

This page intentionally left blank 


\author{
DOE/ORP-2000-19, REV. 0 \\ Reference: DOE/ORP-2000-07, REV. 0
}

\title{
EXTCUTIVE SUMMARY
}

The Hanford Immobilized Low-Activity Tank Waste Performance Assessment (ILAW PA) provides an analysis of the long-term environmental and health impacts of the onsite disposal of Hanford immobilized low-activity tank waste packages. The purpose of the 1998 version ${ }^{1}$ was to provide an assessment that would bound the impacts given the limited sitespecific and waste-specific data available. ${ }^{2}$ The assessment was based on the requirements of DOE Order 5820.2a (Radioactive Waste Management) with the acknowledgment that the order was undergoing revision. The 1998 ILAW PA was conditionally accepted by the Department of Energy and formed part of the basis for the issuance of a Disposal Authorization Statement for the Hanford Site, including the disposal of Immobilized Low-Activity Waste (ILAW). ${ }^{3}$ The conditions of acceptance were to document the waste form release testing conducted in fiscal year 1999 (completed) and to address their "secondary" issues in future performance assessments.

Since the release of the 1998 version of the Hanford Immobilized Low-Acthity Tank Waste Performance Assessment, a significant data collection activity has been undertaken to support the next performance assessment analysis scheduled to be released in 2001 . Specific new data since the last performance assessment include: new glass corrosion data on more relevant glass compositions, site-specific hydrology and geochemical data, and a revised model for the groundwater flow underneath the Hanford Site. Also, programmatic direction is leading to the eelection of a trench design concept as the preferred approach for ILAW disposal. In addition, DOE finalized its new order on radioactive waste management (DOE O 435.1)4. The impacts of the new Order have been fairly small (mainly the time of compliance changed to 1,000 years).

This report documents the performance of the proposed disposal action given the new data that have been collected during the data collection process since the last PA in 1998. The performance of the system is compared to performance objectives that have been developed for the proposed disposal option. Only a limited analysis is given here. The revision of the 1998 IIAW PA, scheduled for next year, will analyze more cases and present a greater depth of material.

In general, the present analysis shows better performance, i.e. lower impacts, when compared to the last performance assessment. The main reasons for lower impacts are increased groundwater flow beneath the disposal facility, better understanding of the waste inventory, and new information about reterdation of importent radionuclides in the vadose zone. For this analysis, the contaminant release data from a relevant glass form composition were used rather than draft procurement limits or contaminant release data from a higher-temperature glass.

' F.M. Mamn, RJ. Puigh II, P.D. Ritumm, N.W. Klipe, J.. Voogd, Y. Chen, C.R. Eiholzer, C.T. Kincaid, B.P. MCOnil, A. LI, G.F. Williameon, N.R. Erown, and P.E. LaMont, Hanford Immobilized Low-Acthity Tank Wasts Performenar Asecesement, DOERL-97-69, U.S. Depertment of Energy, Richlend, Wenhington, Minch 1998.

${ }^{2}$ F.M. Mann and RJ. Puigh II, Data Pacilages for the Hanford Low-lovel Tank Waste Interim Performance Asceasment, WHC-SD-WM-RPT-166, Rev. 0, Westinghouse Fanford Company, Richland, Washington, Jaly 1995.

${ }^{3}$ C.L. Huntoon (Asistant Secretary for Environmertal Management), letter to John T. Conway (Chnirman, Defense Nuclear Facilitien Safety Bourd) U.S. Depertment of Bnergy, Washington, D.C., October 25, 1999.

‘DOE 0 435.1, "Radioactive Waste Managemme", DOS ONm, U.S. Department of Energy, Washington, D.C., July 7, 1999. 


\section{DOE/ORP-2000-19, REV. 0 \\ Refcence: DOE/ORP-2000-07, REV. 0}

These estimated rates are based on a large experimental database and use conservative assumptions. The rate of groundwater flow at the Hanford Site is known to be location specific. Such site-specific geology was used in this analysis. The earlier analysis did not have this site specific information. As the processing of waste is better understood, this information has been added to the inventory information used in this analysis. Finally new, site specific, geochemical information has added to our understanding of mobility for several key radionuclides.

Table ES-1 compares the performance objectives for protecting the general public with the results from the base analysis case calculations for the DOE time of compliance (1,000 years) and for 10,000 years after facility closure (2030). A time of 10,000 years was also used because the NRC has indicated that the performance assessment must also meet their requirements for the ILAW product to be ruled "incidental waste." The estimated all-pathways doses are significantly lower than the performance objectives for ILAW disposal. The point of compliance is a well 100 meters downgradient of the facility.

At 1,000 years, the estimated all-pathways dose is more than a factor of 4,000 less than the performance objective. Even during the first 10,000 years, the estimated doses are approximately a factor of 35 less than the performance objective (25 mrem in a year as stated in the DOE order). Technetium-99 and iodine-129 are estimated to contribute 60 and 25 percent, respectively, of this dose at 10,000 years. The Composite Analysis for Low-Level Waste Dispasal in the 200-Area Plateau of the Hanford Site ${ }^{3}$ which analyzed the impacts from the releases of all activities shows that the impact of ILAW disposal is insignificant during the DOE time of compliance (1,000 years after facility closure). Moreover, the Composite Analysis shows that during the DOE time of compliance, the peak all-pathways dose from all 200 Area sources is less than $10 \mathrm{mrem} / \mathrm{yr}$. Therefore, the composite peak all-pathways dose is less than the performance objective of $100 \mathrm{mrem}$ in a year.

Table.ES-1 Comparison of estimated impacts with performance objectives for protecting the public. The DOE time of compliance is 1,000 years. The point of compliance is a well 100 meters downgradient of the facility.

\begin{tabular}{|l|l|l|l|l|}
\hline Performance Measure & $\begin{array}{l}\text { Performance } \\
\text { Objective }\end{array}$ & $\begin{array}{l}\text { Estimated Impact } \\
\text { at 1,000 y }\end{array}$ & $\begin{array}{l}\text { Estimated Impact at 10,000 y } \\
\text { 1998 ILAW PA Updated Result }\end{array}$ \\
\hline All-pathways [mrem in a y] & 25.0 & 0.0061 & 6.4 & 0.72 \\
\hline
\end{tabular}

Table ES-2 compares the estimated impacts to the performance objectives for protecting the inadvertent intruder. A one-time dose (an acute exposure) scenario and a continuous exposure scenario (a chronic exposure) are defined. The acute dose, estimated by assuming that a person drills a well through the disposal facility and is directly exposed to the drill cuttings, is much less than the performance objective. At the time of compliance, 500 years, ${ }^{126} \mathrm{Sn}$ contributes more than $70 \%$ percent of the acute exposure dose. The continuous exposure, which includes the ingestion of contaminated food and water, the inhalation of air, and direct radiation exposure, is almost a factor of 4 lower than the performance objective. At the time of

\footnotetext{
${ }^{5}$ Kincaid 1998, Kincaid C. T., M. P. Bergeron, C. R. Cale, M. D. Preshley, N. L. Hacxig V. G. Johneon, D. I. Keplen, R J. Serne, G. P. Streile, D. L. Srenge, P. D. Thome, L. W. Vail, G. A. Whyth, S. K. Wurtener. 1998. Compastite Analysts fir Lom fowd Waste Dispasal in the 200-Area Platean of the

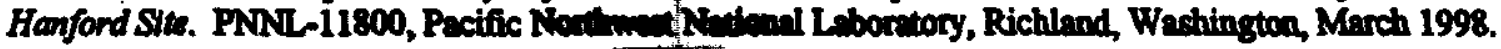
A-viii
} 
compliance (500 years) ${ }^{120} \mathrm{Sn},{ }^{211} \mathrm{Am}$, and ${ }^{239} \mathrm{Pu}$ provide approximately equal contributions to the continuous exposure dose.

The estimated impact for the continuous exposure scenario is closest to the performance objectives in this analysis update. In the 1998 ILAW performance assessment the estimated impact for the continuous exposure scenario was $27.5 \mathrm{mrem}$ in a year. This estimated impact is based on four packages having average inventories of the II.AW radionuclides. These estimated impacts can be mitigated through operational controls based on projected container inventories. Such operational controls will be better defined as the project matures.

Table ES-2 Comparison of estimated impacts with performance objectives for protecting the inadvertent intruder. The time of compliance is $\mathbf{5 0 0}$ years after facility closure.

\begin{tabular}{|l|l|l|c|}
\hline Performance Measure & $\begin{array}{l}\text { Performance } \\
\text { Objective }\end{array}$ & $\begin{array}{l}\text { Estimated Impacts } \\
\text { 1998 LAW PA }\end{array}$ Updated Results \\
\hline Acute exposure [mrem] & 500.0 & 5.5 & 0.9 \\
\hline Continuous exposure [mrem in a year] & 100.0 & 27.5 & 27. \\
\hline
\end{tabular}

Table ES-3 compares the estimated impacts to the performance objectives for protecting the groundwater resources. These performance objectives are based on the federal drinking water standards. At the DOE time of compliance (1,000 years) and the point of compliance (at a well 100 meters downgradient of the disposal facility), the groundwater impacts are not significant (factor of more than 2,000 less). At 10,000 years technetium-99 and iodine-129 are estimated to contribute 57 and $43 \%$, respectively, to the beta-photon emitter dose. Aleo, neptunium-237, and uranium-233, -238 , and -234 are estimated to contribute $22,44,15$, and $17 \%$, respectively, to the alpha emitter concentration in the groundwater. At 10,000 years the estimated impact from beta emitters is a factor of 24 less than the performance objective and the estimated impact from alpha emitters is a factor of approximately 120 less than the performance objective. The radium concentration in the groundwater is estimated to remain insignificant at 10,000 years. The current estimated impacts for protecting the groundwater resources for the RH trench are a factor of 10 less than the impacts estimated in the 1998 IL.AW PA.

The most important drivers for determining peak groundwater concentrations are the following: the inventory of technetium and iodine for beta/photon emitters and neptunium and uranium for alpha emitters, the release rate from the waste form, the amount of mixing in the aquifer, and the geometry of the disposal facility relative to the direction of groundwater flow.

Table LS-3 Comparison of estimated impacts with performance objectives for protecting groundwater resources. The DOE time of compliance is 1,000 years. The point of compliance is a well 100 meters downgradient of the facility.

\begin{tabular}{|l|l|l|l|l|}
\hline Performance Measure & $\begin{array}{l}\text { Performance } \\
\text { Objective }\end{array}$ & $\begin{array}{l}\text { Estimated Impact } \\
\text { at 1,000 y }\end{array}$ & $\begin{array}{l}\text { Estimated Impact at 10,000 y } \\
1998 \text { ILAW PA Updated Results }\end{array}$ \\
\hline $\begin{array}{l}\text { Beta/photon emitters } \\
\text { [mrem in a y] }\end{array}$ & 4.0 & 0.0017 & 2.0 & 0.17 \\
\hline $\begin{array}{l}\text { Alpha emitters } \\
\text { [pCiL] }\end{array}$ & 15.0 & $4.2 \times 10^{-14}$ & 1.7 & 0.13 \\
\hline Radium [pCi/L] & 5.0 & 0.0 & $<0.001$ & 0.0 \\
\hline
\end{tabular}




\section{DOE/ORP-2000-19, REV. 0 \\ Refremce: DOE/ORP-2000-07, REV. 0}

Table ES -4 compares the estimated impacts to the performance objectives for protecting the surface water resources. The DOE time of compliance is 1,000 years and the point of compliance is at a well intersecting the groundwater just before the groundwater mixes with the Columbia River.

Table ES-4 Comparison of estimated impacts with performance objectives for protecting surface water resources. The DOE time of compliance is 1,000 years. The point of compliance is a well located just before the groundwater mixes with the Columbia River.

\begin{tabular}{|l|l|l|l|l|}
\hline Performance Measure & $\begin{array}{l}\text { Performance } \\
\text { Objective }\end{array}$ & $\begin{array}{l}\text { Estimated Impact } \\
\text { at } 1,000 \mathrm{y}\end{array}$ & \multicolumn{2}{|l|}{$\begin{array}{l}\text { Estimated Impact at 10,000 y } \\
1998 \text { IAW PA Updated Results }\end{array}$} \\
\hline $\begin{array}{l}\text { Beta/photon emitters } \\
\text { [mrem in a y] }\end{array}$ & 1.0 & $1.4 \times 10^{-4}$ & 0.07 & 0.014 \\
\hline Alpha emitters [pCi/L] & 15.0 & $6.8 \times 10^{-16}$ & 0.058 & 0.011 \\
\hline Radium [pCi/L] & 0.3 & 0.0 & $<0.001$ & 0.0 \\
\hline
\end{tabular}

At 10,000 years the relative contributions to the beta-photon emitter dose or alpha emitter concentration in the groundwater at a well just before it mixes with the Columbia River are equivalent to the contributions identified in protecting the groundwater resources (see discussion preceding Table ES-3). The only difference is the associated lower magnitude due to the additional dilution that occurs in the groundwater as the contaminants are transported to the river. The estimated impacts at 10,000 years are over a factors of 70 and 1,350, respectively, lower than the performance objectives for beta/photon emitters and alpha emitters, respectively. The calculations are also a factor of 5 lower than the impacts estimated in the 1998 IIAW PA. Because of the large flow of the Columbia River, mixing occurs in the river and the predicted impacts in the River would actually be far lower.

Table ES-5 compares the estimated impacts to the performance objectives for protecting air resources (the values for which are given in federal clean air regulations). The DOE time of compliance is 1,000 years and the point of conpliance is just above the disposal facility. The estimated impacts are significantly lower than the values prescribed in the performance objectives. The other radionuclides that can potentially contribute to the air dose are tritium (as water vapor) and carbon-14 (as carbon dioxide). However, these two radionuclides are not expected to be in ILAW waste packages.

Table ES-5 Comparison of estimated impacts with performance objectives for protecting air resources. The DOE time of compliance is 1,000 years. The point of compliance is just above the disposal facility.

\begin{tabular}{|l|l|l|l|}
\hline Performance Measure & $\begin{array}{l}\text { Performance } \\
\text { Objective }\end{array}$ & $\begin{array}{l}\text { Estimated Impact } \\
1998 \text { IIAW PA Updated Results }\end{array}$ \\
\hline Radon [pCi $\mathrm{m}^{-2} \mathrm{~s}^{-1}$ ] & 20.0 & $<0.001$ & $<0.001$ \\
\hline Other radionuclides [mrem in a y] & 10.0 & $<10^{-2}$ & 0.0 \\
\hline
\end{tabular}

Estimates for the impacts of other hazardous materials in the ILAW waste were investigated. The resulting concentrations in the groundwater near the site or in the groundwater just before it enters the Columbia River were more than a factor of 2,000 less than the 


\section{DOE/ORP-2000-19, REV. 0 Reference: DOE/ORP-2000-07, REV. 0}

performance goals for these materials at 10,000 years after facility closure when the upper bound estimates for inventory were used.

The uncertainties in the ILAW inventory, and facility design were investigated to a limited extent. The estimated impacts from this proposed disposal action are sensitive to these parameters. The investigation of their effect on the estimated impacts provide additional assurance that the performance objectives can be met. The uncertainty in the ILWW inventory for the key radionuclides is typically bounded by the contract limits or the tank nominal inventory. Even if all the technetium were included in the ILAW, the corresponding impacts provided in the tables above would increase by at most a factor of 5 for the remote handled trench design concept. The estimated impact is still below the performance objectives.

The uncertainties in the facility design that were investigated included changing the infiltration rate into the facility, and consideration of an altemate facility design (concrete vault). Changing the water infiltration rate into the facility from $4.2 \mathrm{~mm} / \mathrm{y}$ to $0.9 \mathrm{~mm} / \mathrm{y}$ reduced the estimated impact by more than a factor of 10 for the RH trench. The estimated release rate from a concrete vault design concept was significantly higher than the estimated release rates from the $\mathrm{RH}$ trench. The higher rates are attributed to a larger fraction of the glass exposed to higher $\mathrm{pH}$ than in the trench calculations. Although the release rate from the concrete vault facility was approximately $70 \%$ greater than the trench sipulation at its peak release rate, the estimated impacts for the concrete vault are approximately a factor of 2 or more greater than the estimated impacts for the RH trench. The estimated impacts for protecting the groundwater resource for the concrete vaults are still below the performance objectives for this proposed disposal action.

In summary, based on the new site specific data and improved analytical methods this analysis shows that the conclusion reached in the 1998 ILAW PA that the disposal of ILAW can be performed in a manner that can be reasonably expected to be protective of long-term human health and environmental protection remains valid. This analysis shows that the system has increased its margin of protection for all-pathways and drinking water by a factor greater than 20 for the base analysis case defined for the RH trench and a recharge of $4.2 \mathrm{~mm} / \mathrm{y}$. This calculation is conservative but not bounding. The values for intruder protection remain about the same as identified in the 1998 ILAW PA. 
DOE/ORP-2000-19, REV. 0

Reference: DOE/ORP-2000-07, REV. 0

This page intentionally left blank 
DOE/ORP-2000-19, REV. 0

Reference: DOE/ORP-2000-07, REV. 0

TABLE OF CONTENTS

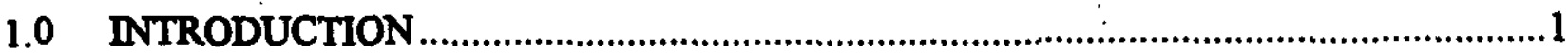

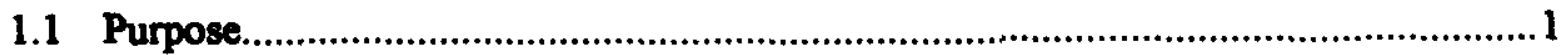

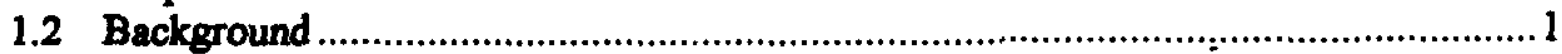

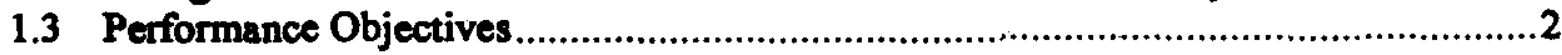

1.4 Approach and Major Data Sources ............................................................................

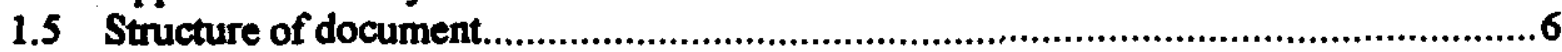

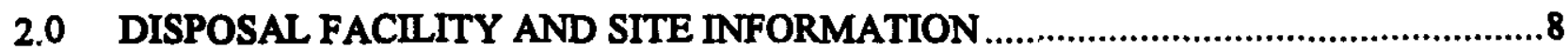

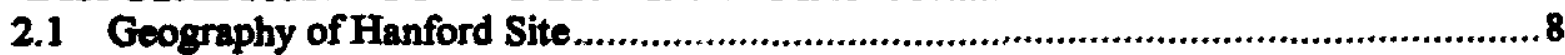

2.2 Disposal Facility Design .................................................................................................

2.2.1 Remote Handled Trench Pre-Conceptual Design.............................................8

2.2.2 Concrete Vault Conceptual Design..............................................................11

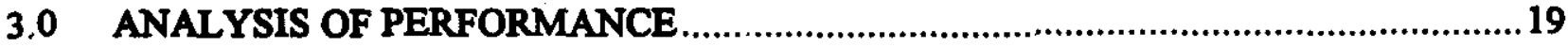

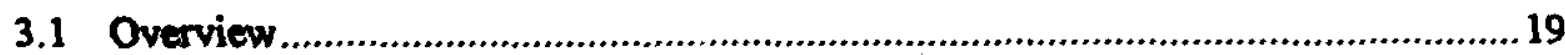

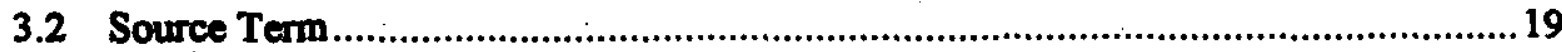

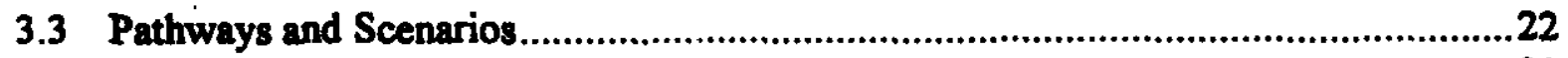

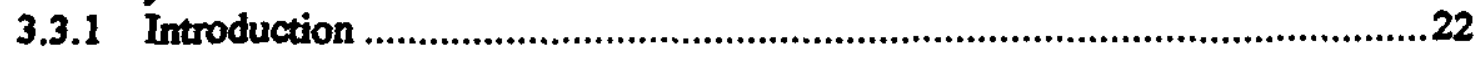

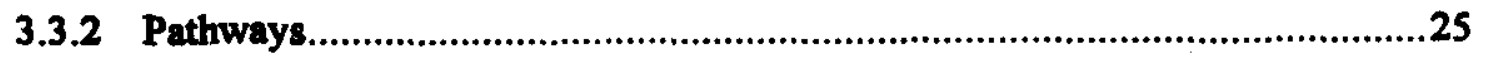

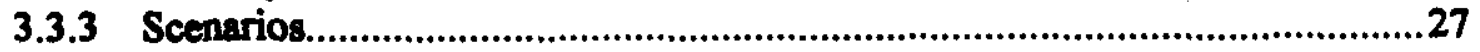

3.3.4 Natural Events .........................................................................................27

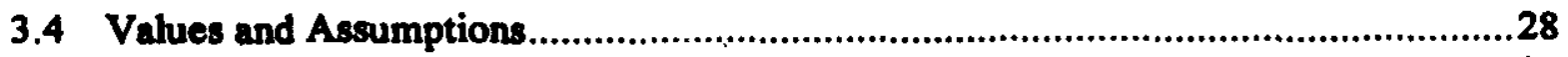

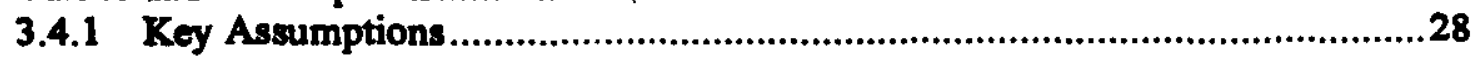

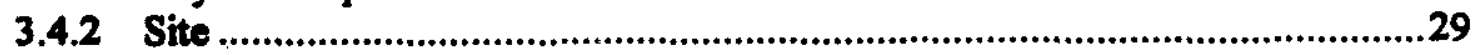

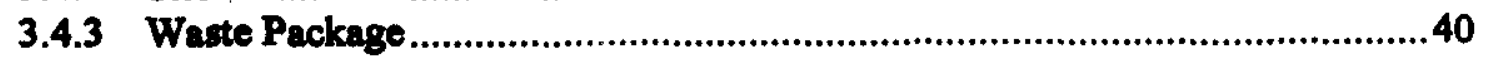

3.4.4 Disposal Facility ......................................................................................43

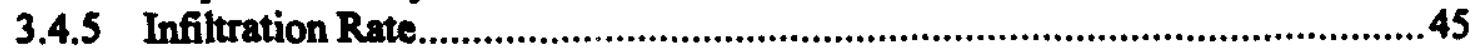

3.4.6 Exposure Parameters ......................................................................................46

3.5 Performance Assessment Methodology ..................................................................47

3.5.1 Introduction ..............................................................................................47

3.5.2 Base Analysis Case and Sensitivity Case Deseriptions ..................................48

3.5.3 Waste Form Release and Near-Field Contaminant Transport Code Calculations ................................................................................................50

3.5.4 Far Field Moisture Flow and Contaminant Transport Code Calculations .......54

3.5.5 Groundwater Flow and Contaminant Transport Code Calculations.................57

3.5.6 Integration Calculations ................................................................................64

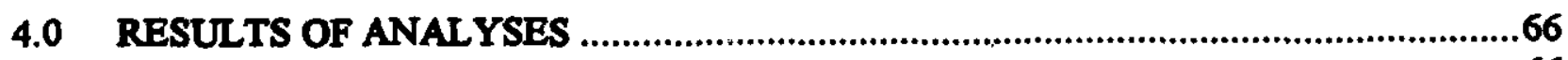

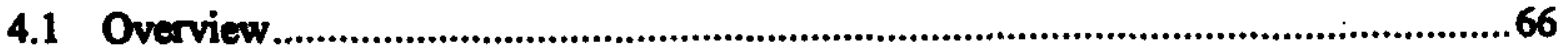

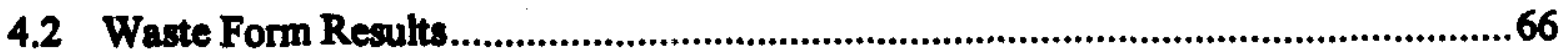

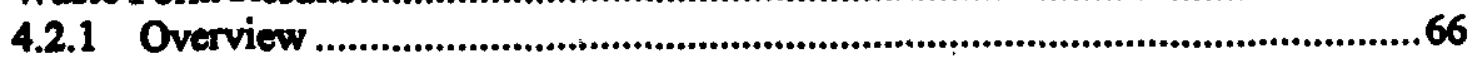

4.2.2 Unsaturated Flow Field Used in Waste Form Release Calculations ................66

4.2.3 RH Trench Simulation with $4.2 \mathrm{~mm} / \mathrm{y}$ Recharge Rate ..................................67

4.2.4 RH Trench Simulation with $0.9 \mathrm{~mm} / \mathrm{y}$ Recharge Rate ....................................67

4.2.5 New II.AW Vault Simulation with $4.2 \mathrm{~mm} / \mathrm{y}$ Recharge Rate..........................68

4.2.6 Discussion of Waste Form Release Calculations .............................................68 
4.3 Far-Field Results

4.3.1 Contaminant Transport through the Far Field .........................................81

4.3.2 Geochemical $\left(\mathrm{K}_{\mathrm{d}}\right)$ Impact on Far Field Contaminant Transport ....................8.82

4.3.3 Recharge Impacts on Far Field Contaminant Transport ..............................83

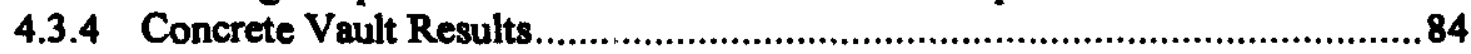

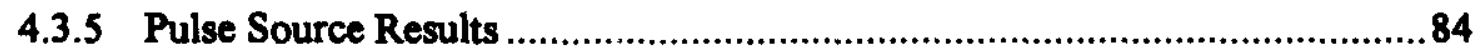

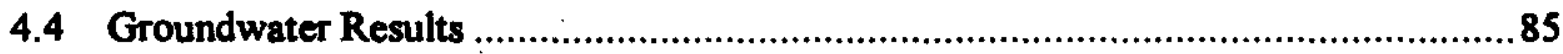

4.4.1 Simulated Results at $100 \mathrm{~m}$ Downgradient Well..........................................85

4.4.2 Well-Intercept Factor at Distant Downgradient Wells...............................89

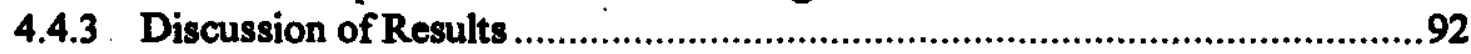

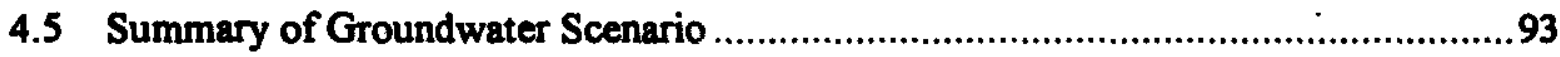

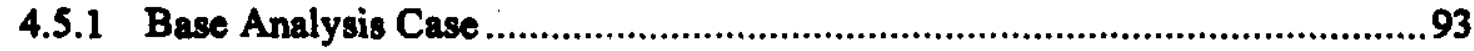

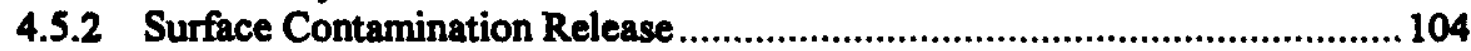

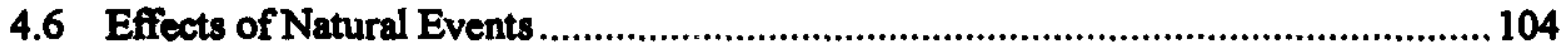

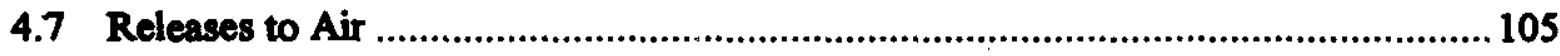

5.0 RESULTS FOR INADVERDENT INTRUDER SCENARIO .....................................107

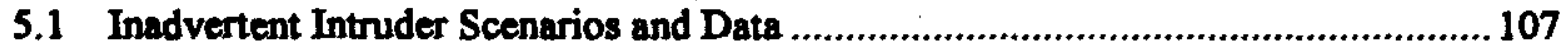

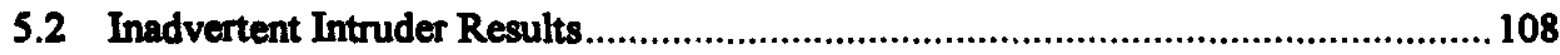

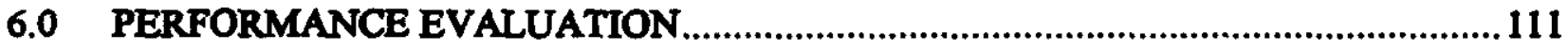

6.1 Comparison of Estimated Impacts to Performance ............................................111

6.1.1 Protection of General Public.....................................................................111

6.1.2 Protection of Inadvertent Intruders .......................................................111

6.1.3 Protection of Groundwater Resources ....................................................112

6.1.4 Protection of Surface Water Resources..........................................................113

6.1.5 Protection of Air Resources......................................................................113

6.1.6 Summary..................................................................................113

6.2 Performance Sensitivity to Key Parameter Uncertainties.........................................114

6.3 Uncertainties Regarding Glass Pefformance ........................................................115

6.4 Summary of the Impact of Differences Between the 1998 ILAW PA and This Document .......................................................................................................119

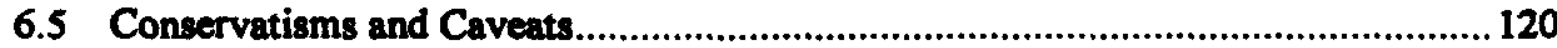

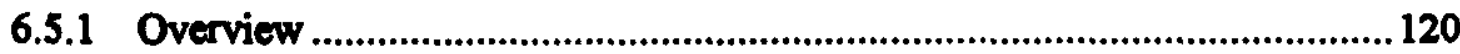

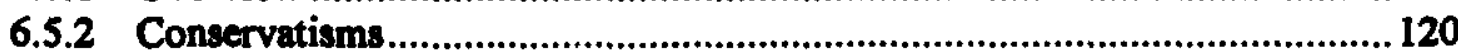

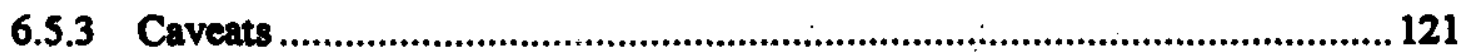

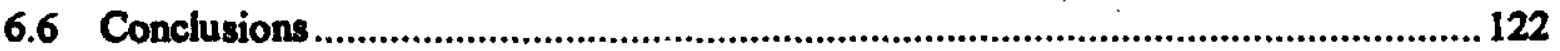

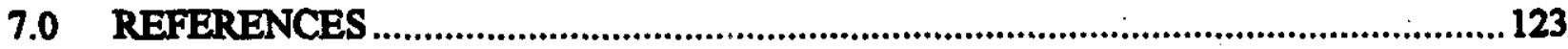

8.0 PEER REVIEW

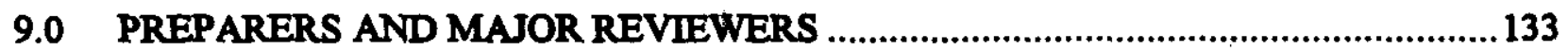




\section{LST OF TABLES}

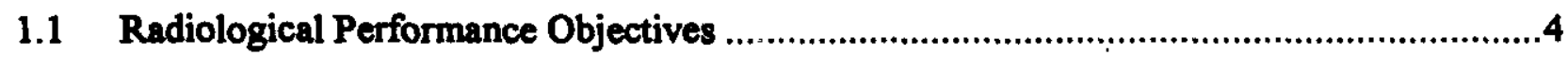

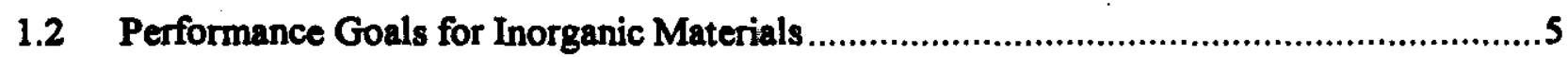

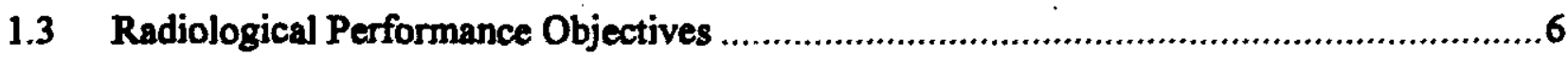

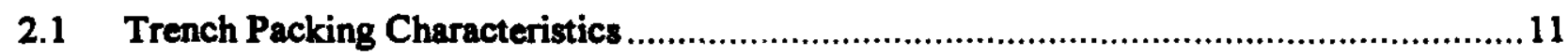

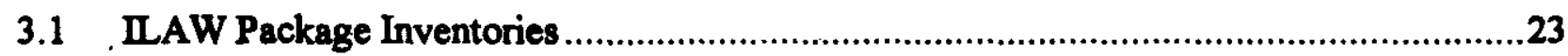

3.2 Best-Estimate Hydraulic Parameter Values For Near-Field Materials..............................31

3.3 Best-Estimate Hydraulic Parameter Values For Far-Field Layers .....................................32

3.4 Best-Estimate $\mathbf{K}_{\mathbf{d}}$ Values For The Chemically Impacted Far-Field Sand Sequence ...........34

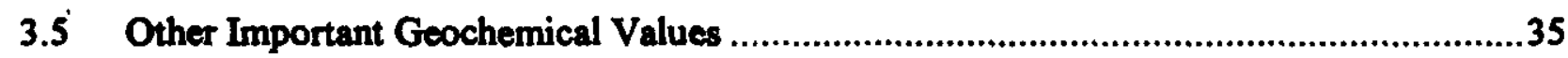

3.6 Summary of Best Estimate Parameters for LAWBP1 Glass ...........................................44

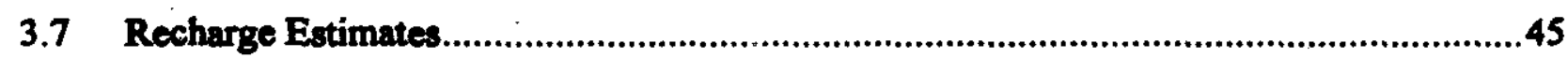

3.8. Annual Unit Dose Factors for Post-Intrusion Resident ...............................................46

3.9 Total Annual Unit Dose Factors for Low-Water Infiltration Cases .................................47

3.10 Far-Field Transport Parameters...................................................................................57

4.1 Well Intercept Factors at $100 \mathrm{~m}$ and $1000 \mathrm{~m}$ for the Remote Handled Trench Disposal

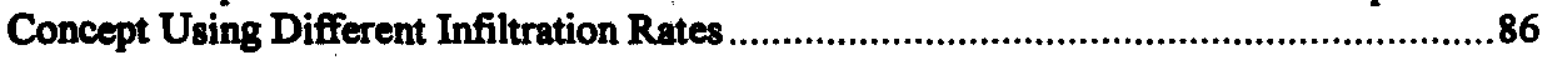

4.2 Well Intercept Factors at $100 \mathrm{~m}$ and $1000 \mathrm{~m}$ for the Concrete Vault Disposal Concept Using Different Infiltration Rates.

4.3 Well Intercept Factors at Several Downgradient Well Locations for Remote Handled Trench Disposal Concept Using Different Infiltration Rates..............................................90

4.4 Well Intercept Factors at Several Downgradient Well Locations for Concrete Vault Disposal Concept Using Different Infilitration Rates.

4.5 Estimated Impact from the RH Trench Base Analysis Case at a Well 100 Meters Downgradient from the Disposal Facility

4.6 RH Trench Base analysis case - Major Contributors at 10,000 Years to the Estimated Beta/Photon Drinking Water Dose at a Well 100 Meters Downgradient from the Disposal Facility .

4.7 Major Contributors at 10,000 Years to the Alpha Emitting Radionuclide Concentration at

a Well 100 Meter Downgradient from the Disposal Facility

4.8 Major Contributors at 10,000 Years to the All Pathways Dose at a Well 100 Meter Downgradient from the RH Trench Disposal Facility.

4.9 Estimated Impact from the Base Analysis Case from Groundwater Just Before Mixing with the Columbia River.

4.10 Comparison of Groundwater Hazardous Chemical Concentrations to Performance Goals (Impacts in units of $\mathrm{mg} / \mathrm{L}$ ). 


\section{DOE/ORP-2000-19, REV. 0 \\ Referenc: DOE/ORP-2000-07, REV. 0}

4.11 Comparison of Hazardous Material Concentrations in the Well Next to the Columbia River Compared to Performance Goals (Impacts in units of $\mathrm{mg} / \mathrm{L}$ ). 104

4.12 Estimated Impact from the RH Trench Base Analysis Case at a Well 100 Meters Downgradient from the Disposal Facility Using Upper Bound ILAW Inventory ............ 106

4.13 Estimated Impact from the Alternate Disposal Facility Design Case (Concrete Vault Design) at a Well 100 Meters Downgradient from the Disposal Facility Facility Using the Nominal IIAW Inventory............................................................................................. 106

4.14 Estimated Impact from the Waste Form Sensitivity Case (Recharge $=0.9 \mathrm{~mm} / \mathrm{y}$ ) at a Well 100 Meters Downgradient from the Disposal Facility........................................................106

5.1 Facility Dimensions and Waste Volume Exhumed …................................................112

5.2 Doses at Compliance Date (500 Years after Facility Closure) .....................................112

6.1 Comparison of Estimated Impacts with Performance Objectives for Protecting the Public. .115

6.2 Comparison of Estimated Impacts with Performance Objectives for Protecting the Inadvertent Intruder

6.3 Comparison of Estimated Impacts with Performance Objectives for Protecting Groundwater Resources.

6.4 Comparison of Estimated Impacts with Performance Objectives for Protecting Surface Water Resources

6.5 Comparison of Estimated Impacts with Performance Objectives for Protecting Air Resources

6.6 Impact of Inventory Uncertainty on Groundwater Scenarios at 10,000 Years After Facility Closure

6.7 Impact of Inventory Uncertainty on Inadvertent Intruder Scenarios............................118

6.8 Impact of Disposal Facility Uncertainty on Groundwater Scenarios ................................119

6.9 Effect of Updated Model Inputs on the Estimated Beta/Gamma Drinking Water Dose at 10,000 Years.

\section{LIST OF FIGURES}

Figure 2.1 Map of the Hanford Site and Its Location Within Washington ..........................................9 Figure 2.2 Locations of the ILAW Disposal Site in the Southeast Quadrant of the 200 East Area

Figure 2.3 RH Trench Pre-Conceptual Layout at the IIAW Disposal Site......................................13

Figure 2.4 RH Trench Pro-Conceptual Design,

Figure 2.5 Pro-Conceptual RH Trench Liner System Detail.................................................................15

Figure 2.6 Concrete Vault Conceptual Design Layout at the ILAW Disposal Site ........................16

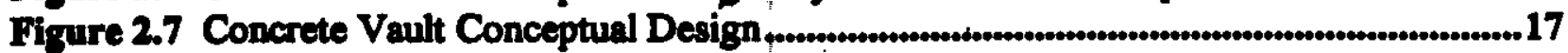

Figure 3.1 Eight Sequential Steps for the Groundwater Pathway .............................................................27

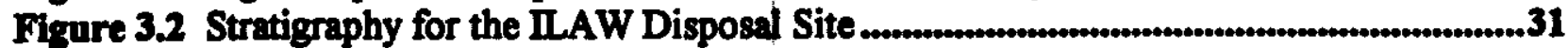

Figure 3.3 Comparison of Generalized Geology and Hydrostratigraphic Columns........................40 


\section{DOE/ORP-2000-19, REV. 0 Referace: DOE/ORP-2000-07, REV. 0}

Figure 3.4 Hydraulic Conductivity Distribution Obtained for the Uppermost Unconfined Aquifer from Inverse Calibration for 1979 Conditions . 41

Figure 3.5 Modeling Strategy for Assessing II.AW Disposal System.............................................51

Figure 3.6 Material Zones for Remote Handled Trench Waste Form Release Simulations........55

Figure 3.7 Material Zones for New ILAW Vault Waste Form Release Simulations.....................56

Figure 3.8 Predicted Water Table for Post-Hanford Conditions for Assumed Steady-State

Conditions (as Simulated after 350 Years) .

Figure 3.9 Predicted Water Table for Post-Hanford Conditions for Assumed Steady-State Conditions between ILAW Disposal Facility and Columbia River (as Simulated after 350 Yers).

Figure 3.10 Finite Element Grid Used in Local -Scale Model

Figure 3.11 Three-Dimensional Distribution of Major Hydrogeologic Units in the Local-Scale Model

Figure 3.12 Distribution and Hydraulic Conductivities of Major Hydrostratigraphic Units in Local-scale Model.

Figure 4.1 Steady-state Moisture Content for the RH Trench 1-D Waste Form Release Model at Different Recharge Rates (horizontal dotted lines represent boundaries between material zones and material names shown along the right axis).

Figure 4.2 Calculated Steady-state Moisture Content for the Vault 1-D Waste Form Release Model (horizontal dotted lines represent boundaries between material zones and material names are shown along right axis)

Figure 4.3 Technetium Flux Across Bottom Boundary of Model, Normalized to Amount of Technetium Originally in Waste Form ......................................................................................73

Figure 4.4 TcO; Concentrations for RH Trench Simulation With Recharge Rate of $4.2 \mathrm{~mm} / \mathrm{y}$ (Horizontal Dotted Lines Represent Boundaries Between Material Zones And Material Names Are Shown Along Right Axis).

Figure 4.5 LAWABP1 Dissolution Rate for RH Trench Simulation With Recharge Rate of 4.2 $\mathrm{mm} / \mathrm{y}$ (Horizontal Dotted Lines Represent Boundaries Between Material Zones And Material Names Are Shown Along Right Axis). 75

Figure4.6 pH for RH Trench Simulation With Recharge Rate of $4.2 \mathrm{~mm} / \mathrm{y}$ (Horizontal Dotted Lines Represent Boundaries Between Material Zones And Material Names Are Shown Along Right Axis).

Figure 4.7 TOO; Concentrations for RH Trench Simulation With Recharge Rate of $0.9 \mathrm{~mm} / \mathrm{y}$ (Horizontal Dotted Lines Represent Boundaries Between Material Zones And Material Names Are Shown Along Right Axis).

Figure 4.8 LAWABP1 Dissolution Rate for RH Trench Simulation With Recharge Rate of 0.9 mm/y (Horizontal Dotted Lines Represent Boundaries Between Material Zones And Material Names Are Shown Along Right Axis).

Figure4.9 pH for RH Trench Simulation With Recharge Rate of $0.9 \mathrm{~mm} / \mathrm{y}$ (Horizontal Dotted Lines Represent Boundaries Between Material Zones And Material Names Are Shown Along Right Axis).

Figure 4.10 TcO; Concentrations for New II.AW Vault Simulation With Recharge Rate of 4.2 mm/y (Horizontal Dotted Lines Represent Boundaries Between Material Zones And Material Names Are Shown Along Right Axis).

Figure 4.11 LAWABP1 Dissolution Rate For New ILAW Vwult Simulation With Recharge Rate of $4.2 \mathrm{~mm} / \mathrm{y}$ (Horizontal Dotted Lines Represent Boundaries Between Material Zones And Material Names Are Shown Alone Right Axis) 


\section{DOE/ORP-2000-19, REV. 0 \\ Refreac: DOE/ORP-2000-07, REV. 0}

Figure 4.12 pH for New ILAW Vault Simulation With Recharge Rate of $4.2 \mathrm{~mm} / \mathrm{y}$ (Horizontal Dotted Lines Represent Boundaries Between Material Zones And Material Names Are

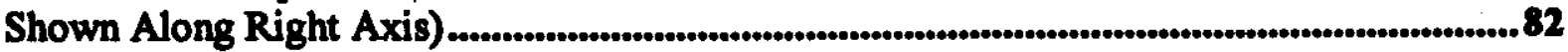

Figure 4.13 Normalized Contaminant Flux to the Aquifer for the RH Trench and a Recharge of

$4.2 \mathrm{~mm} / \mathrm{y}$ (Linear Scale for Release Fraction) ........................................................................84

Figure 4.14 Effect of Recharge Rate on the Normalized Contaminant Flux to the Aquifer for the

RH Trench (Logarithmic Scale for Release Fraction) .............................................................85

Figure 4.15 Release Rate from a 1 Curie Source for One Year from the RH Trench .................87

Figure 4.16 Distribution of Hydraulic Head in Unconfined Aquifer in Local-Scale Model .......88

Figure 4.17 Areal Distribution of Contaminant Plume Resulting the Remote-Handled Trench

Concept

Figure 4.18 Vertical Distribution of a Contaminant Plume Resulting the Remote-Handled

Trench Concept Along the Approximate Centerline of the Plume ...........................................90

Figure 4.19 Concentration History at $100 \mathrm{~m}$ and $1000 \mathrm{~m}$ wells, Local Scale Model (Note the

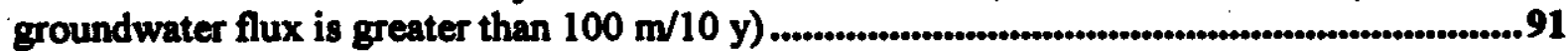

Figure 4.20 Areal Distribution of Contaminant Plume between ILAW New Facility and

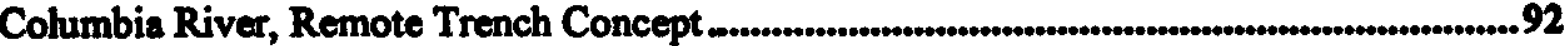

Figure 4.21 Concentration History at Selected Well Locations, Site-Wide Model.......................93

Figure 4.22 Time Dependence for RH Trench Beta/Photon Drinking Water Dose to 10,000

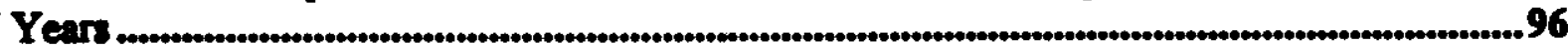

Figure 4.23 Time Dependence for Alpha Emitting Radionuclide Concentrations...0......................97

Figure 4.24 Time Dependence for All Pathway Doses for RH Trench ........................................... 100

Figure 5.1 Acurte Dose at RHT .........................................................................................................................113

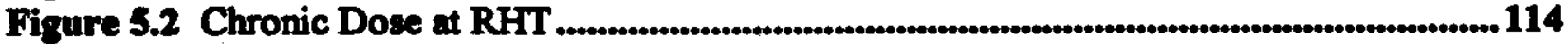

Figure 6.1 Radial Distribution Plot of $200^{\circ} \mathrm{C}$ VHT Corrosion Rates for HLP Series of ILAW

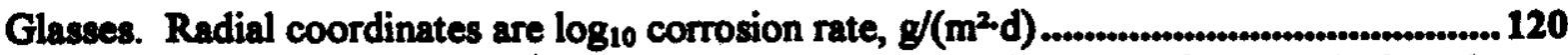

Figure 6.2 Cumulative Distribution Plot of $200^{\circ} \mathrm{C}$ VHT Corrosion Rates for HLP Series of

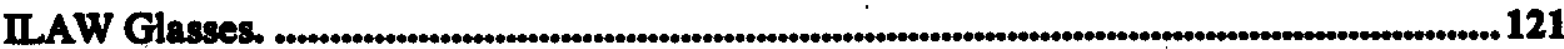

Figure 6.3 Comparison of Glass Corrosion Rate in PUF Tests at $99^{\circ} \mathrm{C}$ and $2 \mathrm{~mL} / \mathrm{d}$................ 121 Figure 6.4 Comparison of Glass Corrosion Rate in PUF Tests at $99^{\circ} \mathrm{C}$ and VHT Tests at $200^{\circ} \mathrm{C}$. 


\author{
DOE/ORP-2000-19, REV. 0 \\ Reference: DOE/ORP-2000-07, REV. 0
}

\title{
1.0 INTRODUCTION
}

\subsection{Purpose}

The purpose of this document is to provide a comparison of the estimated immobilized low-activity waste (ILAW) disposal system performance against established performance objectives using the best estimates for parameters and models to describe the system. The principal advances in knowledge since the last performance assessment (known as the 1998 IIAW PA [Mann 1998a]) have been in site specific information and data on the waste form performance for BNFL, Inc. relevant glass formulations. The white paper also estimates the maximum release rates for technetium and other key radionuclides and chemicals from the waste form. Finally, this white paper provides limited information on the impact of changes in waste form loading.

\subsection{Background}

The Hanford Site, in south-central Washington State has been used extensively for producing defense materials by the Department of Energy (DOE) and its predecessors, the U.S. Atomic Energy Commission and the U.S. Energy Research and Development Administration. Starting in the 1940s, Hanford Site operations were dedicated primarily to producing muclear weapons materials. In the 1960s, operations were expanded to producing electricity from a dual-purpose reactor, conducting diverse research projects, and managing waste. In the late 1980, the Site's original mission ended. This mission left a large inventory of radioactive and mixed hazardous waste stored in underground single- and double-shell tanks in the Hanford Site 200 Areas.

Today, the Site's missions are environmental restoration, energy-related research, and tochnology development. As part of its environmental restoration mission, DOE is proceeding with plans to permanently dispose of the waste stored on site. These plans are based on the Hanford Federal Facility Agreement and Cotesent Order (Tri-Party Agreement) (Ecology 1998) and the Record of Decision for the Tank Waste Remediation Systems Envirommental Impact Statement (DOE 1997a). These documents chll for the waste to be retrieved from the Hanford Site's single- and doublo-shell tanks, then trented to separate the low-level fraction (now called the low-activity fraction) from the high-level (including transuranic) fraction. Both fractions will then be immobilized.

The two immobilized products (the small volume of high-level immobilized waste and the much larger volume of low-activity waste) will be disposed of in different locations. The high-level waste will be storid on the Hanford Site until sent to a federal geologic repository. The low-activity immobilized waste will be placed in a near-surface disposal system in the 200 East Area of the Hanford Site. On the order of $160,000 \mathrm{~m}^{3}\left(5,600,000 \mathrm{ft}^{3}\right)$ of low-activity immobilized waste will be disposed of under this plan. This is among the largest amounts of waste in the DOE Complex (DOE 1997b) and has one of the largest inventories of long-lived radiomuclides to be placed in a low-level watte disposal facility. 
The DOE is proceeding (DOE/RL 1996a) to procure privatized services for treating and immobilizing the tank waste. In August 1998, DOE placed a contract with BNFL, Inc. (DOE/BNFL 1998) to produce the ILAW with the first delivery currently scheduled in 2008. The first phase of the effort would extend for about a decade. The contract for the second phase, in which most of the waste will be processed, will be awarded in the second half of the decade.

In 1998, the first version of the Hanford Immobilized Low-Activity Tank Waste Performance Assessment (Mann 1998a) was issued and submitted to the Low-Level Waste Federal Review Group (LFRG) for review and action. The Low-Level Waste Federal Review Group has completed their review. Based on this review the DOE has accepted the ILAW Performance Assessment (DOE 1999d). This acceptance is contingent upon the following actions: providing the LFRG with documentation of the near-term glass test results to provide confidence that the glass performance assumed in the performance assessment can actually be achieved, and addressing the secondary issues identified by the review team in future revisions to the performance assessment. Documentation on relevant glass performance has been provided to the LFRG for their review (French 1999). The secondary issues identified by the LFRG will be addressed in the next iteration of the ILAW PA scheduled for release in 2001.

Most of the data in the 1998 ILAW PA comes from the Data Packages for the Hanford Low-level Tank Waste Interim Performance Assessment (Mann 1995), although some data were updated to reflect more current values. Data to support the planned 2001 ILAW PA have been assembled and documented in Mann/Puigh (2000). The major advances in understanding or programmatic changes since the 1998 II AW PA have been:

- Waste form release data from BNFL, Inc. relevant glass formulations

- New borehole providing ILAW site specific geologic, chemical, and hydraulic data

- New groundwater model

- Expanded understanding to extrapolate laboratory measurements to field conditions

- Selection of a different disposal facility conceptual design (Taylor 1999a).

\subsection{Performance Objectives}

Performance objectives are the standards against which the effect of the disposal action will be compared. The manual (DOE 1999b -1$)$ for the new DOE order on radioactive waste management, DOE 0435.1 (DOE 1999a) provides performance objectives for a performance assessment as

(1)(a) "25 mrem in a year total effective dose equivalent from all exposure pathways"

(1)(b) " 10 mrem in a year total effective dose equivalent " via the air pathway

(1)(c) "Release of radon shall not exceed 10 mrem in a year total effective dose equivalent"

(2)(g) "include an assessment of impacts to water resources"

(2)(h) "The intruder analysis shall use performance measures for chronic and acute exposures, respectively, of $100 \mathrm{mrem}$ in a year and $500 \mathrm{mrem}$ in a year total effective dose equivalent. 


\section{DOE/ORP-2000-19, REV. 0 \\ Beference: DOENORP-2000-07, REV. 0}

(2)(b) "The point of compliance shall correspond to the point of highest projected dose or concentration beyond a 100 meter buffer zone surrounding the disposal waste."

(2) "include calculations for a 1,000 year period after closure"

The proposed disposal action will also require a Resource Conservation and Recovery Act (RCRA) Part B permit and concurrence from the U.S. Nuclear Regulatory Commission (NRC) on the waste classification of ILAW. Therefore, additional constraints were considered in the establishment of the performance objectives used in the ILAW PAs. Specifically, the RCRA concerns bring in the impacts of hazardous wastes. The NRC has indicated that the ILAW would be considered "incidental waste" (Paperello 1997) if the following three conditions are met: 1) DOE follows its program plan for separating and immobilizing the waste to the maximum extent possible that is technically and economically possible, 2) the wastes meet Class C standards of 10 CFR 61, and 3) the performance assessments continue to indicate that public health and safety would be protected to standards comparable to those established by the NRC for the disposal of low-level waste. The first two conditions are built into the current contract for the immobilization of the ILAW. Also, the 1998 ILAW performance assessment has shown that the public and safety are protected. As "incidental waste," the IAW would not fall under the licensing authority of NRC. This position does require the assessment of estimated impacts at 10,000 years after closure of the disposal site.

Therefore, as documented in Mann (1999a), the various requirements noted above have been merged into a unified set of performance objectives for the ILAW PA. Table 1.1 presents the performance objectives for radionuclides. Table 1.2 presents the performance objectives for chemicals identified as most important by the data quality objectives (DQO) process performed for the low activity and high level waste feed delivery (Patello 1999).

\subsection{Approach and Major Data Sources}

This assessment is being performed to incorporate the most recent data and information into the disposal system performance calculations. The calculations are built around a base analysis case that reasonably describes our understanding of the system's components and how they will interact. This step starts with the known conditions and estimates the impacts from those conditions (i.e. a forward calculation). This calculation and the limited sensitivity calculations are based on the latest information and data that have been developed for the 2001 ILAW PA (Mann/Puigh 2000).

Because of the long timeframes involved in this analysis, estimates of impacts require computer simulations, rather than rely on direct observations. The models used in the analyses are very flexible and should be adequate to describe the evolving features of the disposal system. The major sources of information for the base analysis case are presented in Table 1.3. Selected sensitivity cases were performed to determine the impact of selected assumptions or data uncertainties. Among the most important were the following:

- A different recharge rate was considered

- A different facility design was considered

- Different amounts of key radionuclides were included (e.g., inventory uncertainty). 
DOE/ORP-2000-19, REV. 0

Reference: DOE/ORP-2000-07, REV. 0

Table 1.1 Radiological Performance Objectives

\begin{tabular}{|c|c|}
\hline \multicolumn{2}{|c|}{ Protection of General Public and Workers ab } \\
\hline $\begin{array}{l}\text { All-pathways dose from only this facility } \\
\text { All-pathways dose including other Hanford Site sources }\end{array}$ & $\begin{array}{l}25 \text { mrem in a year }{ }^{\text {hb }} \\
100 \mathrm{mrem} \text { in a year }\end{array}$ \\
\hline \multicolumn{2}{|c|}{ Protection of an Inadvertent Intruder ${ }^{a}$} \\
\hline $\begin{array}{l}\text { Acute exposure } \\
\text { Continuous. exposure }\end{array}$ & $\begin{array}{r}500 \text { mrem } \\
100 \text { mrem in a year }\end{array}$ \\
\hline \multicolumn{2}{|c|}{ Protection of Groundwater Resources ${ }^{\text {W }}$, } \\
\hline $\begin{array}{l}\text { Alpha emitters } \\
{ }_{226} \mathrm{Ra} \text { plus }{ }^{228} \mathrm{Ra} \\
\text { All others (total) } \\
\text { Beta and photon emitters }\end{array}$ & $\begin{array}{r}5 \mathrm{pCi} / \mathrm{L} \\
15 \mathrm{pCi} / \mathrm{L} \\
4 \mathrm{mrem} \text { in a year }\end{array}$ \\
\hline \multicolumn{2}{|c|}{ Protection of Surface Water Resources b. } \\
\hline $\begin{array}{l}\text { Alpha emitters } \\
{ }_{226}{ }_{\mathrm{R} a} \text { plus }{ }^{222} \mathrm{Ra} \\
\text { All others (total) } \\
\text { Beta and photon emitters }\end{array}$ & $\begin{array}{r}0.3 \mathrm{pCi} / \mathrm{L} \\
15 \mathrm{pCi} / \mathrm{L} \\
1 \mathrm{mrem} \text { in a year }\end{array}$ \\
\hline \multicolumn{2}{|c|}{ Protection of Air Resource wh, } \\
\hline $\begin{array}{l}\text { Radon (flux through surface) } \\
\text { All other radionuclides }\end{array}$ & $\begin{array}{l}20 \mathrm{pCi} \mathrm{m}^{-2} \mathrm{~s}^{-1} \\
10 \mathrm{mrem} \text { in a year }\end{array}$ \\
\hline
\end{tabular}

- All doses are calculated as effective dose equivalents; all concentrations are in water taken from a well. Values given are in addition to any existing amounts or background.

bvaluated for 1,000 and 10,000 years, but calculated to the time of peak or 10,000 years, whichever is longer.

c Evaluated for 500 years, but calculated to 1,000 years.

- Evaluated at the point of maximal exposure, but no closer than 100 meters (328 feet) from the disposal facility.

- Evaluated at the 200 East Area fence (assumed future boundary of the DOE site).

Evaluated at the disposal facility.

- Evaluated at the Columbia River, no mixing with the river is assumed.

h Main driver is DOE Orders on Radioactive Waste Management (DOE 1988 and DOE 1999a)

i Main driver is DOE Order 5400.5, Radiation Protection of the Public and the Environment (DOE 1993).

J Main driver is National Primary Drinking Water Regulations (40 CFR 141).

kain driver is Washington State Surface Water Standards (WAC 173-201A)

${ }^{1}$ Main driver is National Emission Standards for Hazardous Air Pollutants (40 CFR 61H and 40 CFR 610). 
Table 1.2 Performance Goals for Inorganic Materials (See Mann 1999a for Source of Performance Goals)

\begin{tabular}{|c|c|c|c|}
\hline \multicolumn{4}{|c|}{ Inorganics } \\
\hline \multicolumn{2}{|c|}{ Chemical } & Groundwater & Surface Waters \\
\hline \multicolumn{2}{|c|}{ Ammonia (NH3) } & & $\mathrm{mg} / \mathrm{L}$ \\
\hline \multicolumn{2}{|c|}{ Antimony (Sb) } & $0.006 \mathrm{mg} / \mathrm{L}$ & 0.006 \\
\hline \multicolumn{2}{|c|}{ Arsenic (As) } & $0.00005 \mathrm{mg} / \mathrm{L}$ & $\mathrm{mg} / \mathrm{L}$ \\
\hline \multicolumn{2}{|c|}{ Barium (Ba) } & $1.0 \mathrm{mg} / \mathrm{L}$ & $\mathrm{mg} / \mathrm{L}$ \\
\hline \multicolumn{2}{|c|}{ Beryllium (Be) } & $0.004 \mathrm{mg} / \mathrm{L}$ & 0.004 \\
\hline \multicolumn{2}{|c|}{ Cadmium (Cd) } & $0.005 \mathrm{mg} / \mathrm{L}$ & $0.00077 \mathrm{mp} / \mathrm{L}$ \\
\hline \multicolumn{2}{|c|}{ Chlorine (C) } & $\mathbf{m} \mathbf{L} \mathbf{L}$ & $m g / L$ \\
\hline \multicolumn{2}{|c|}{ Chromium (Cr) } & $\mathrm{mg} / \mathrm{L}$ & 0.011 \\
\hline \multicolumn{2}{|c|}{ Copper (Cu) } & $\mathrm{mg} / \mathrm{L}$ & 0.0078 \\
\hline \multicolumn{2}{|c|}{ Cyanide (CN) } & $\mathrm{mg} / \mathrm{L}$ & 0.0052 \\
\hline \multicolumn{2}{|c|}{ Fluoride (F-) } & $\mathrm{mg} / \mathrm{L}$ & $\mathrm{mg} / \mathrm{L}$ \\
\hline \multicolumn{2}{|l|}{ Iron (Fe) } & $\mathrm{mg} / \mathrm{L}$ & \\
\hline \multicolumn{2}{|l|}{ Lead (Pb) } & $\mathrm{mg} / \mathbf{L}$ & $0.0015 \mathrm{mg} / \mathrm{L}$ \\
\hline \multicolumn{2}{|c|}{ Manganese (Mn) } & $\mathrm{mg} / \mathrm{L}$ & \\
\hline \multicolumn{2}{|c|}{ Mercury (Hg) } & $0.002 \mathrm{mg} / \mathrm{L}$ & $0.000012 \mathrm{mg} / \mathrm{L}$ \\
\hline \multicolumn{2}{|c|}{ Nickel (Ni) } & & 0.115 \\
\hline \multicolumn{2}{|c|}{ Nitrate as N (NO2) } & $\mathrm{mg} / \mathrm{L}$ & $\mathrm{mg} / \overline{\mathrm{L}}$ \\
\hline \multirow{2}{*}{\multicolumn{2}{|c|}{ Nitrite as N (NO3) }} & $\mathrm{mg} / \mathrm{L}$ & $\mathrm{mg} / \mathrm{L}$ \\
\hline & Nitrite plus Nitrate & $\mathrm{mg} / \mathrm{L}$ & $\mathrm{mg} / \mathrm{L}$ \\
\hline \multicolumn{2}{|c|}{ Selenium (Se) } & $\mathrm{mg} / \mathrm{L}$ & 0.005 \\
\hline \multicolumn{2}{|c|}{ Silver $(A x)$} & $\mathrm{mg} / \mathrm{L}$ & \\
\hline \multicolumn{2}{|c|}{ Sulfate (SO4) } & $\mathrm{mg} / \mathrm{L}$ & \\
\hline \multicolumn{2}{|c|}{ Thallium (TI) } & $0.002 \mathrm{mg} / \mathrm{L}$ & \\
\hline Zinc (Zn) & & $\mathrm{m} g / \mathrm{L}$ & 0.072 \\
\hline Orranics & & & \\
\hline CAS\# & Constituent (a) & Groundwater & Surface Waters \\
\hline $56-23-5$ & Carbon tetrachloride & $0.0003 \mathrm{mg} / \mathrm{L}$ & 0.005 \\
\hline $67-66-3$ & Chloroform & $0.007 \mathrm{mg} / \mathrm{L}$ & \\
\hline $71-43-2$ & Benzene & $0.001 \mathrm{~m} / \mathrm{L}$ & 0.005 \\
\hline $71-55-6$ & 1,1,1-Trichloroethane & $0.003 \mathrm{mg} / \mathrm{L}$ & $\mathrm{m} \mathrm{g} / \mathrm{L}$ \\
\hline $75-09-2$ & \begin{tabular}{|l} 
Dichloromethane (Methylene Chloride) \\
\end{tabular} & $0.005 \mathrm{mg} / \mathrm{L}$ & 0.005 \\
\hline $79-00-5$ & 1,1,2-Trichloroethane & $0.005 \mathrm{mg} / \mathrm{L}$ & 0.005 \\
\hline $79-01-6$ & 1,1,2-Trichloroethylene & $0.005 \mathrm{mg} / \mathrm{L}$ & 0.005 \\
\hline $95-47-6$ & o-Xylene & $\mathrm{mg} / \mathrm{L}$ & $\mathrm{m} / \mathrm{L}$ \\
\hline $100-41-4$ & Ethyl benzene & $\mathrm{mg} / \mathrm{L}$ & $\mathrm{m} / \mathrm{L}$ \\
\hline $106-46-7$ & 1,4-Dichlorobenzene & $0.004 \mathrm{mg} / \mathrm{L}$ & 0.075 \\
\hline $108-88-3$ & Toluene & $\mathrm{mg} / \mathrm{L}$ & $\mathrm{mg} / \mathrm{L}$ \\
\hline $127-18-4$ & 1,1,2,2-Tetrachloroethene & $0.005 \mathrm{mg} / \mathrm{L}$ & 0.005 \\
\hline
\end{tabular}

- No entry in a cell indicates that no limit was found. 
DOE/ORP-2000-19, REV. 0

Reference: DOE/ORP-2000-07, REV. 0

Table 1.3 Major Sources of Information for the Base Analysis Case

\begin{tabular}{|c|c|c|}
\hline Data Type & Major Source & Data Base Reference \\
\hline Location & $\begin{array}{l}\text { The new facilities are just southwest of the PUREX } \\
\text { Facility (in the } 200 \text { East Area). }\end{array}$ & Rutherford 1997 \\
\hline Waste Form & $\begin{array}{l}\text { Waste package design based on early BNFL, Inc. } \\
\text { documentation and River Protection Project } \\
\text { planning. }\end{array}$ & $\begin{array}{l}\text { Puigh 1999; also in } \\
\text { Mann/Puigh } 2000 \\
\text { Appendix I }\end{array}$ \\
\hline Inventory & $\begin{array}{l}\text { Based on Best Basis Inventory estimates (calculated } \\
\text { from modeling Hanford Site production reactors } \\
\text { corrected for off-site transfers, and discharges to the } \\
\text { ground and biased to tank measurements). } \\
\text { ASSUMED separations into high- and low-activity } \\
\text { fractions, and off-gas generation. }\end{array}$ & $\begin{array}{l}\text { Wootan 1999; also in } \\
\text { Mann/Puigh 2000 } \\
\text { Appendix H }\end{array}$ \\
\hline $\begin{array}{l}\text { Long-term } \\
\text { waste form } \\
\text { performance }\end{array}$ & $\begin{array}{l}\text { Based on data collected on BNFL, Inc. relevant } \\
\text { glass formulations. }\end{array}$ & $\begin{array}{l}\text { McGrail 1999; also } \\
\text { in Mann/Puigh } 2000 \\
\text { Appendix K }\end{array}$ \\
\hline $\begin{array}{l}\text { Disposal } \\
\text { facility design: }\end{array}$ & $\begin{array}{l}\text { ASSUMED from preconceptual ideas for the } \\
\text { remote handled trench and preliminary design for } \\
\text { the concrete vault. }\end{array}$ & $\begin{array}{l}\text { Puigh 1999; also in } \\
\text { Mann/Puigh } 2000 \\
\text { Appendix I }\end{array}$ \\
\hline Recharge & $\begin{array}{l}\text { Estimates were derived from lysimeter and tracer } \\
\text { measurements collected by the ILAW PA activity } \\
\text { and by other projects combined with a modeling } \\
\text { analysis. }\end{array}$ & $\begin{array}{l}\text { Fayer 1999; also in } \\
\text { Mann/Puigh } 2000 \\
\text { Appendix J }\end{array}$ \\
\hline Geotechnical & $\begin{array}{l}\text { Taken from geotechnical measurements studies of } \\
\text { Il.AW site borehole and other locations in the } \\
\text { Hanford Site } 200 \text { East Area. }\end{array}$ & $\begin{array}{l}\text { Khaleel 1999, Meyer } \\
1999, \text { and Kaplan } \\
1999 ; \text { also in } \\
\text { Mann/Puigh } 2000 \\
\text { Appendiced L, M, } \\
\text { and N, respectively }\end{array}$ \\
\hline$\overline{\text { Expc }}$ & $\begin{array}{l}\text { Taken from past Hanford Site documents and } \\
\text { experience and DOE Order } 435.1 \text { direction. }\end{array}$ & $\begin{array}{l}\text { Rittmann 1999; also } \\
\text { in Mann/Puigh 2000 } \\
\text { Appendix O }\end{array}$ \\
\hline
\end{tabular}

\subsection{Structure of document}

The structure of this document follows the general format of the 1998 IIAW PA (Mann 1998a). Section 2.0 provides an overview of the Hanford Site and description of the disposal facility design. Section 3.0 provides a description of the source term associated with the proposed disposal action, a description of the pathways and scenarios that lead to exposure or environmental impact, the data used in estimaing the impacts, and the performance assessment methodology. Section 4.0 provides the results from the application of the assessment methodology to the system. These results are provided for the near field, waste form, far field, and groundwater calculations. Section 5.0 provides the results for the inadvertent intruder 


\section{DOE/ORP-2000-19, REV. 0 \\ Reference: DOE/ORP-2000-07, REV. 0}

scenarios. Section 6.0 provides an evaluation of the disposal system performance against the performance objectives listed in Section 1.0. Section 7.0 lists the references and section 8.0 documents the results of the peer review. Finally, section 9.0 provides a brief resume for the authors and reviewers. 
DOE/ORP+2000-19, REV. 0

Beference: DOE/ORP-2000-07, REV. 0

\subsection{DISPOSAL FACILITY AND SITE INFORMATION}

\subsection{Geography of Hanford Site}

The Hanford Site is a $1450-\mathrm{km}^{2}$ (560- $\left.\mathrm{mi}^{2}\right)$ area of semiarid land located in south-central Washington State. The Hanford Site is owned by the U.S. Government and restricted to uses approved by the DOE. Figure 2.1 shows the Hanford Site in relation to the rest of the state. The major cities in the region, Seattle, Portland, and Spokane are over $160 \mathrm{~km}(100 \mathrm{mi})$ from the Hanford Site.

The major features of regional geography are the nearby rivers and mountains. The Columbia River, which forms the eastern boundary of the Hanford Site, is an important source of water and hydroelectric power for the region. Other important rivers near the Hanford Site are the Yakima River to the southwest and the Snake River to the east. The Cascade Mountains, which are about $160 \mathrm{~km}(100 \mathrm{mi})$ to the west, have an important effect on the climate of the area.

Figure 2.2 shows the locations of two disposal sites that have been considered in the 1998 IAW PA: the ILAW Disposal Site (located southwest of the PUREX Plant) and the Existing vaults (located east of the PUREX plant and formerly known as the Grout Vaults). Both sites are located in the 200 East Area within the Hanford Site. The current planning is to use the ILAW disposal site as the primary site for disposal of ILAW waste.

\subsection{Disposal Facility Design}

The ILAW disposal planning was to utilize the existing disposal vaults from the grout program suitably modified to roceive ILAW packages and new disposal facility concrete vaults currently in their early design phase. In December 1999 the Department of Energy has identified the remote handled trench as the baseline concept for ILAW disposal at Hanford (Taylor 1999a). The existing disposal vaults may also be used by the program. This white paper will consider both concepts in assessing long term environmental impacts from the proposed disposal action.

\subsubsection{Remote Handled Trench Pre-Conceptual Design}

The Remote Handled (RH) trench concept has been chosen as the baseline for the ILAW Disposal Project (Taylor 1999a). This trench concept is similar to the Radioactive Mixed Waste Burial Trench that was designod and constructied to accept solid waste at Hanford. Under the ILAW disposal planning described below, the disposal facility is a Resource Conservation and Recovery Act (RCRA) compliant landfill (i.e., double lined trench with leachate colloction system). Many operational aspects and ancillary activities of the landfill (e.g., leachate collection and disposition, storm water contro/ installation of surface barrier at closure, etc.) would be similar to that incorporated into the Radioactive Mixed Waste Burial Trench. However, operational activities related to ILAW package receipt and emplacement in the trench would be modified to accommodate the different package size associated with remote-handled II.AW packages. 
Figure 2.1 Map of the Hanford Site and Its Location Within Washington

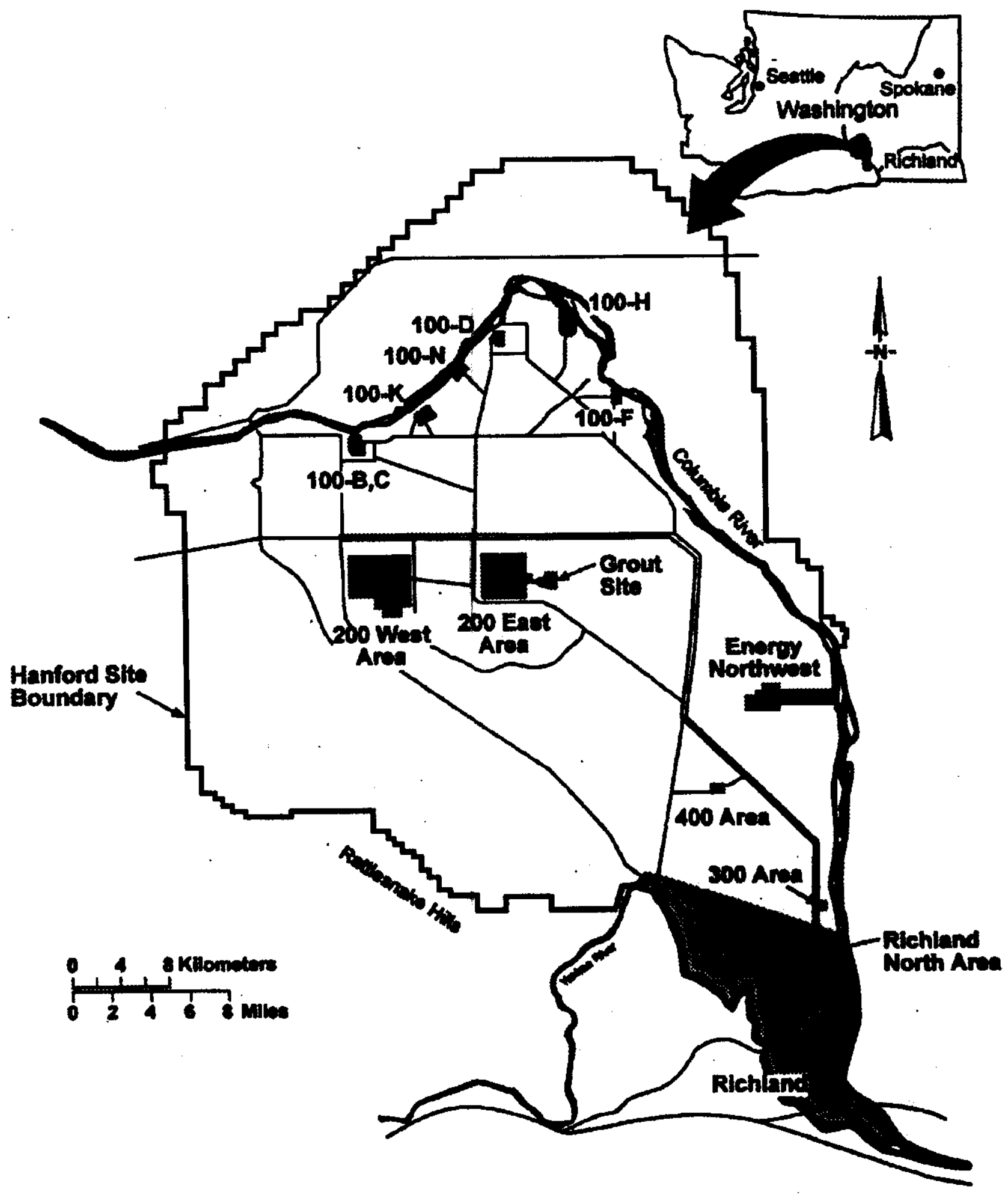


Figure 2.2 Locations of the ILAW Disposal Site in the Southeast Quadrant of the 200 East Area

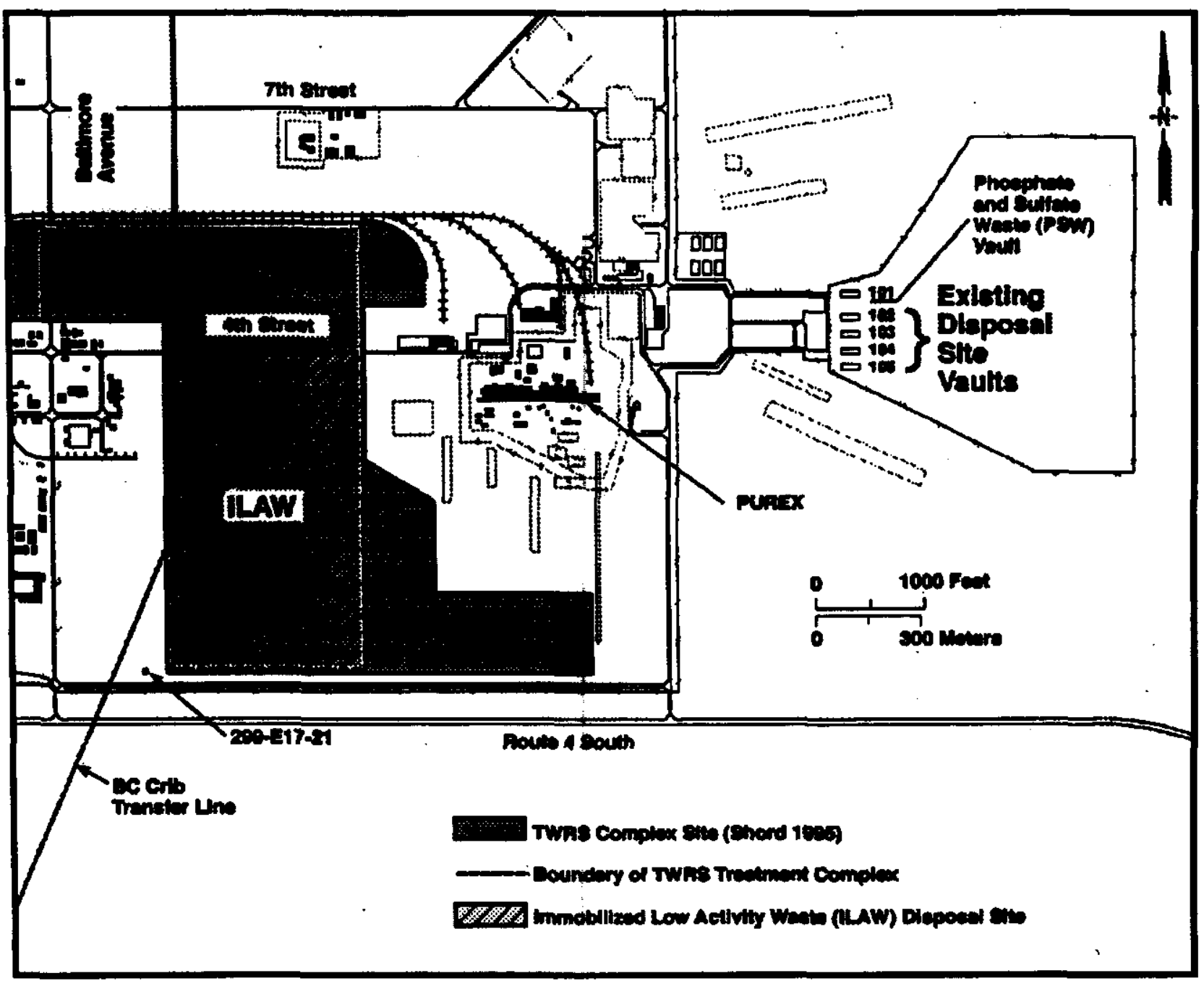

The design concept layout of the trenches within the ILAW disposal site is shown schematically in Figure 2.3. The trench side slopes are in a ratio of 3:1. The dimensions shown in Figure 2.3 represent the inner trench dimengions. Figure 2.4 shows the design concept layout for the waste package loading into the RH trench. Finally Figure 2.5 shows the preconceptual design for the liner system. This design concept will evolve as the design for the ILAW disposal trench is developed.

Specific details of the trench packing are presented in Table 2.1. A cell is defined as a contiguous group of waste packages in a given layer. In this analysis a waste package size of 1.4 m cubed (DOE/BNFL 1998 - contract modification 10) is used (see section.3.4.3). Given this packing density, approximately 6 trenches are needed to accommodate the entire Phase 1 and Phase 2 ILAW production. 
DOE/ORP-2000-19, REV. 0

Reforence: DOEJORP-2000-07, REV. 0

Table 2.1 Trench Packing Characteristics.

\begin{tabular}{|c|c|c|c|}
\hline Layer ${ }^{(\Omega)}$ & Cells per layer & Matrix size per cell ${ }^{(b)}$ & Packages per layer \\
\hline 1 & 2 & $6 \times 132$ & 1,584 \\
\hline 2 & $\overline{3}$ & $6 \times 140$ & 2,520 \\
\hline 3 & $\overline{4}$ & $7 \times 150$ & 4,200 \\
\hline 4 & 6 & $6 \times 160$ & 5,760 \\
\hline & & tal packages per trench & 14,064 \\
\hline
\end{tabular}

(a) Layer 1 is the bottom layer as shown in Figure 2.4; layer 4 is the top layer

(b) Matrix size per cell is defined as the number of waste packages in a cell. The first number refers to the number of packages along the width dimension of the trench and the second number refers to the number of packages along the length dimension.

The details for the closure cover shown in Figure 2.4 have not been designed. For this report the closure cap (aurface barrier) is assumed to have the same relative thickness, materials and slope as the modified RCRA subtitle C closure cap defined in Puigh (1999 - Section 4). A capillary break consisting of a 1 meter thick sand layer immediately below the surface barrier and gravel between the top of the trench and the sand layer is assumed. The sand plus gravel layers together are 4 meters over the center of the trench and have a $2 \%$ slope towards the long edge of each trench. The RCRA subtitle $\mathrm{C}$ closure cap and the capillary break have a combined thickness of greater than $5 \mathrm{~m}$ per NRC requirements (10 CR 61).

\subsubsection{Concrete Vault Conceptual Design}

An alternate set of calculations for a concrete vault design is based on an earlier conceptual design for the new ILAW disposal facilities (Pickett 1998) that utilizes a long concrete vault concept divided into cells. Figure 2.6 shows schematically the conceptual layout of the vaults within the ILAW disposal site. Figure 2.7 shows schematically the conceptual design dimensions for the vault disposal system. Each vault will be an underground, opentopped, concrete vault approximately $23 \mathrm{~m} \mathrm{(76} \mathrm{ft)} \mathrm{wide,} 207.8 \mathrm{~m}(686 \mathrm{ft})$ long, and $11.0 \mathrm{~m}$ ( $26.7 \mathrm{ft})$ in height. The top of the vault walls will extend $1 \mathrm{~m}(3.3 \mathrm{ft})$ above grade. Each vault will be divided into 11 cells, separated by concrete partition walls $(0.45 \mathrm{~m}$ thick). The vault can accommodate 6 layers of waste packages $1.4 \mathrm{~m}$ in height. One layer of waste packages corresponds to $12 \times 14=168$ waste packages. Each vault will hold 6 waste package layers. Assuming the waste package geometry is a $1.4 \mathrm{~m}$ cube, the spacing between each waste package (including the walls) is $9.3 \mathrm{~cm}$ (3.7 in) along the width dimension, $11.5 \mathrm{~cm}$ (4.5 in) along the length dimeneion, and $10 \mathrm{~cm}$ (4 in) betwoen each layer of waste packages. Based on the Kirkbride (1999) estimate of approximately 70,000 packages needed for disposal of all plannod ILAW waste, only 7 new disposal vaults would be required to complete the disposal of all ILAW (assuming the existing vaults are not used).

Each vault is built above a RCRA-compliant leak detection and collection system. It consists of a cast-in-place reinforced concrete basin approximately $209.5 \mathrm{~m}$ (687.0 ft) long, $24.7 \mathrm{~m}(81 \mathrm{ft})$ wide with walls $1.07 \mathrm{~m}$ (3.5 t) high. The basin floor is $0.6 \mathrm{~m}$ (2 ft) thick and contains steel reinforcing bars within. The catch basin is lined with two flexible membrane liners, and on top of these lie a layer of gravel with perforated collection pipe routed to sumps, 
one at each end of a vault. Liquids entering the sump can be removed by use of a portable pump lowered down a riser pipe.

Interim closure for each filled cell in the new disposal facility will consist of placing concrete shield covers (assumed to be $1.4 \mathrm{~m} \times 1.4 \mathrm{~m} \mathrm{x} 0.3 \mathrm{~m}$ ) on the top layer of waste packages. The filler material layer is assumed to have a depth of $0.3 \mathrm{~m}(1.0 \mathrm{ft})$ above the concrete shield covers. A "controlled density fill" consisting of a mixture of Portland cement, fly ash, aggregate, water, and admixtures is then placed on top of the filler material layer. The depth of the "controlled density fill" is $0.45 \mathrm{~m}(1.5 \mathrm{ft})$. A waterproof membrane layer (assumed to be $60 \mathrm{mil}$ high density polyethylene [HDPE]) is placed over the interim closed vault. After all cells in the vault have been filled and interim closed, a closure cap consisting of a capillary break followed by a modified RCRA subtitle C surface cap will be placed over the entire vault. Again the capillary break consists of a 1 meter thick sand layer immediately below the surface barrier and gravel between the top of the concrete vault and the sand layer is assumed. The sand plus gravel layers together are assumed to be 4 meters over the center of the trench and have a $2 \%$ slope towards the long edge of each vault. 
DOE/ORP-2000-19, REV. 0

Reference: DOE/ORP-2000-07, REV. 0

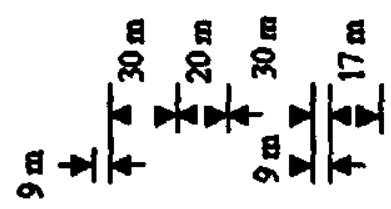

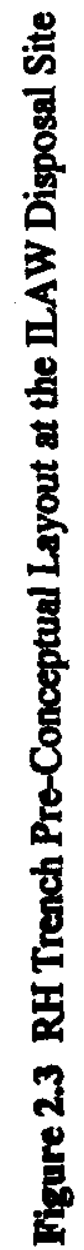

约
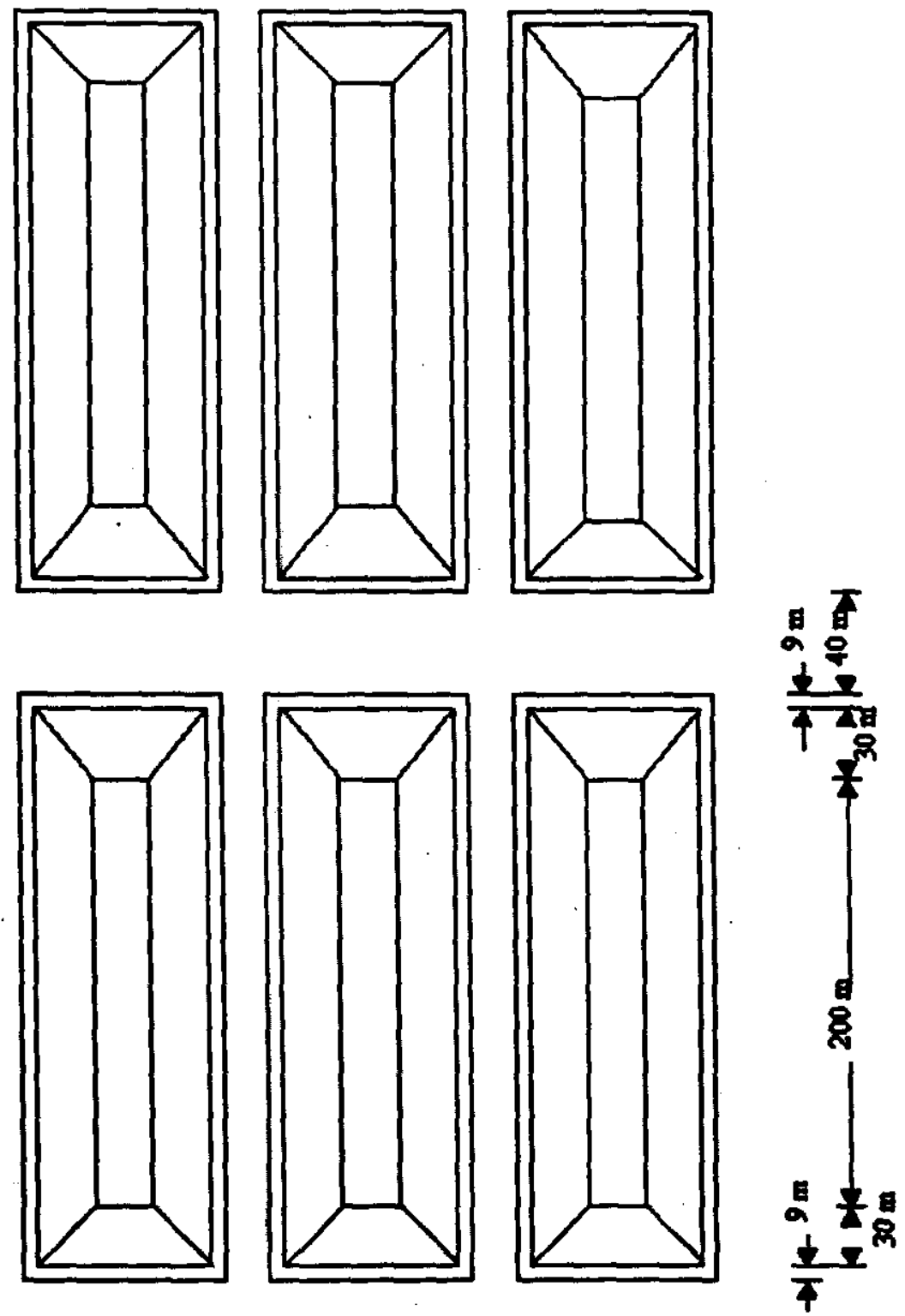
DOE/ORP-2000-19, REV. 0

Beference: DOE/ORP-2000-07, REV. 0

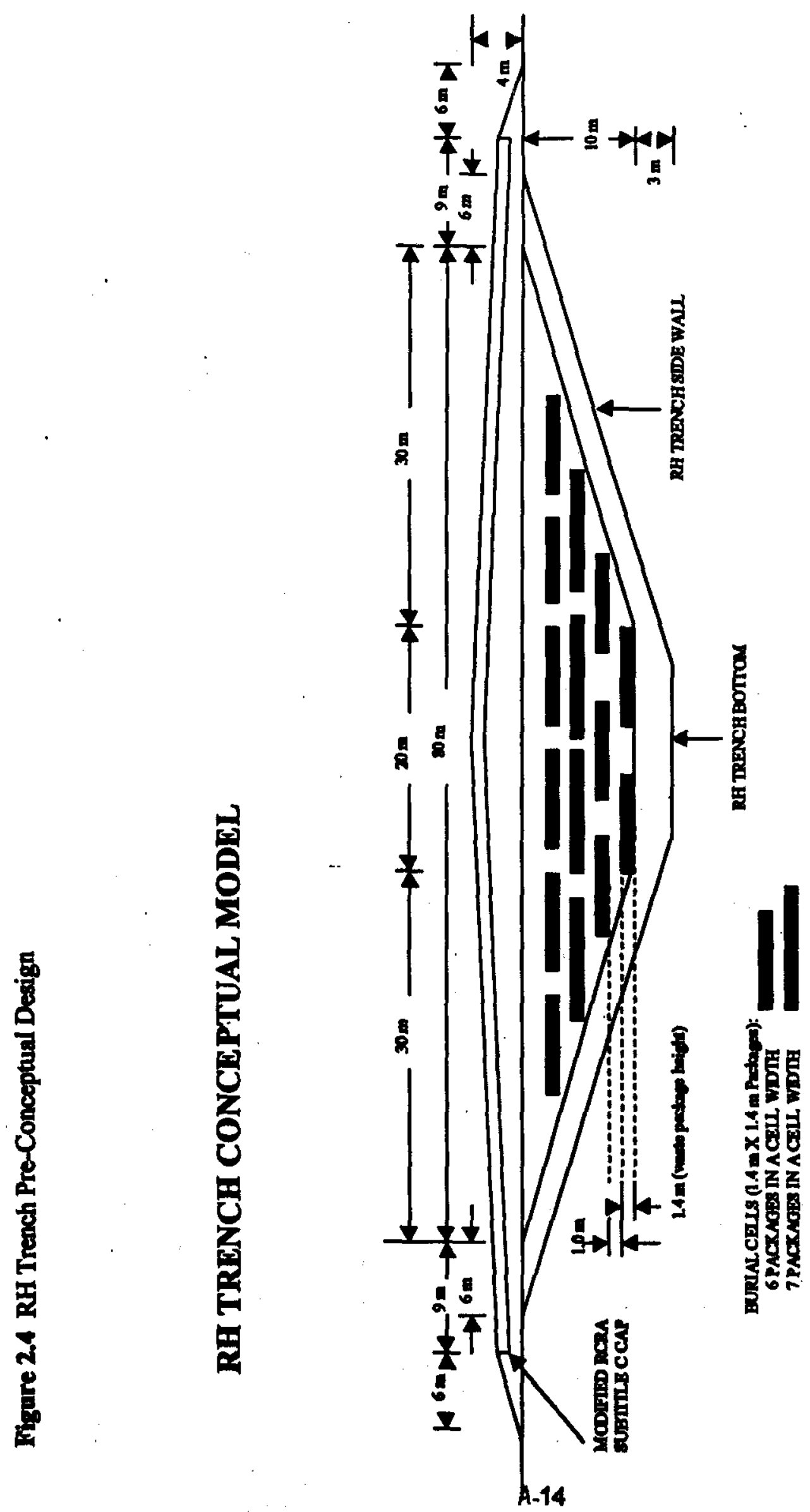




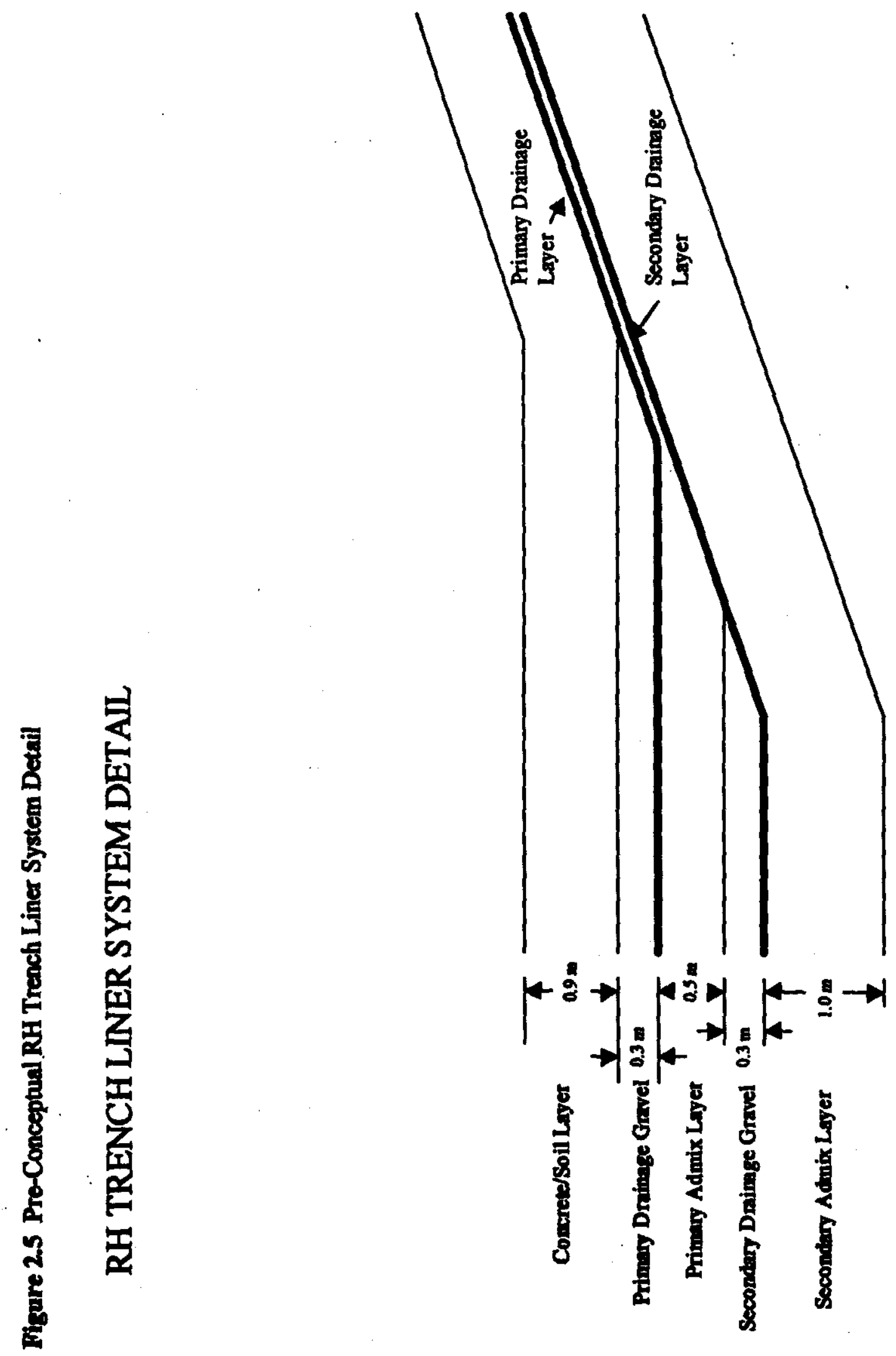


$E$
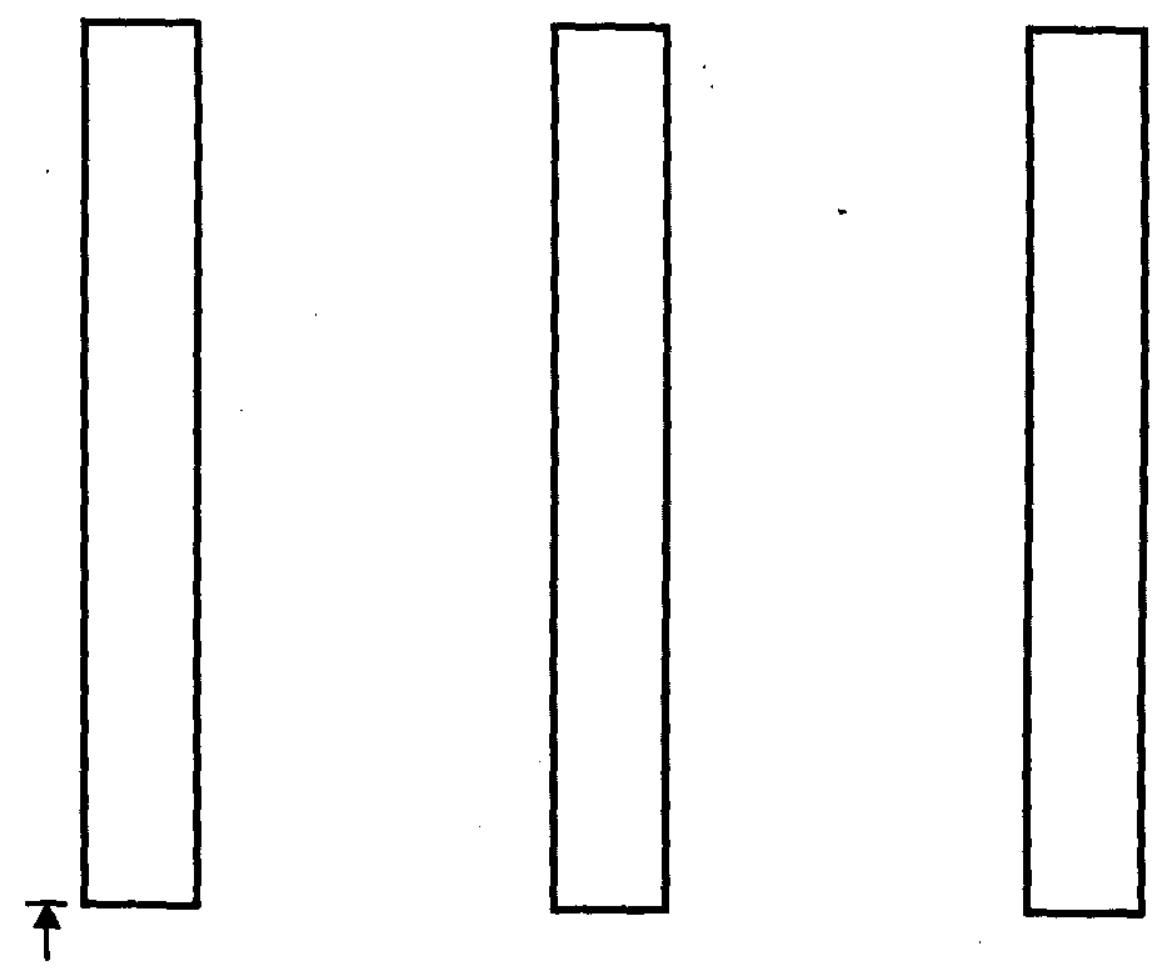

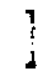

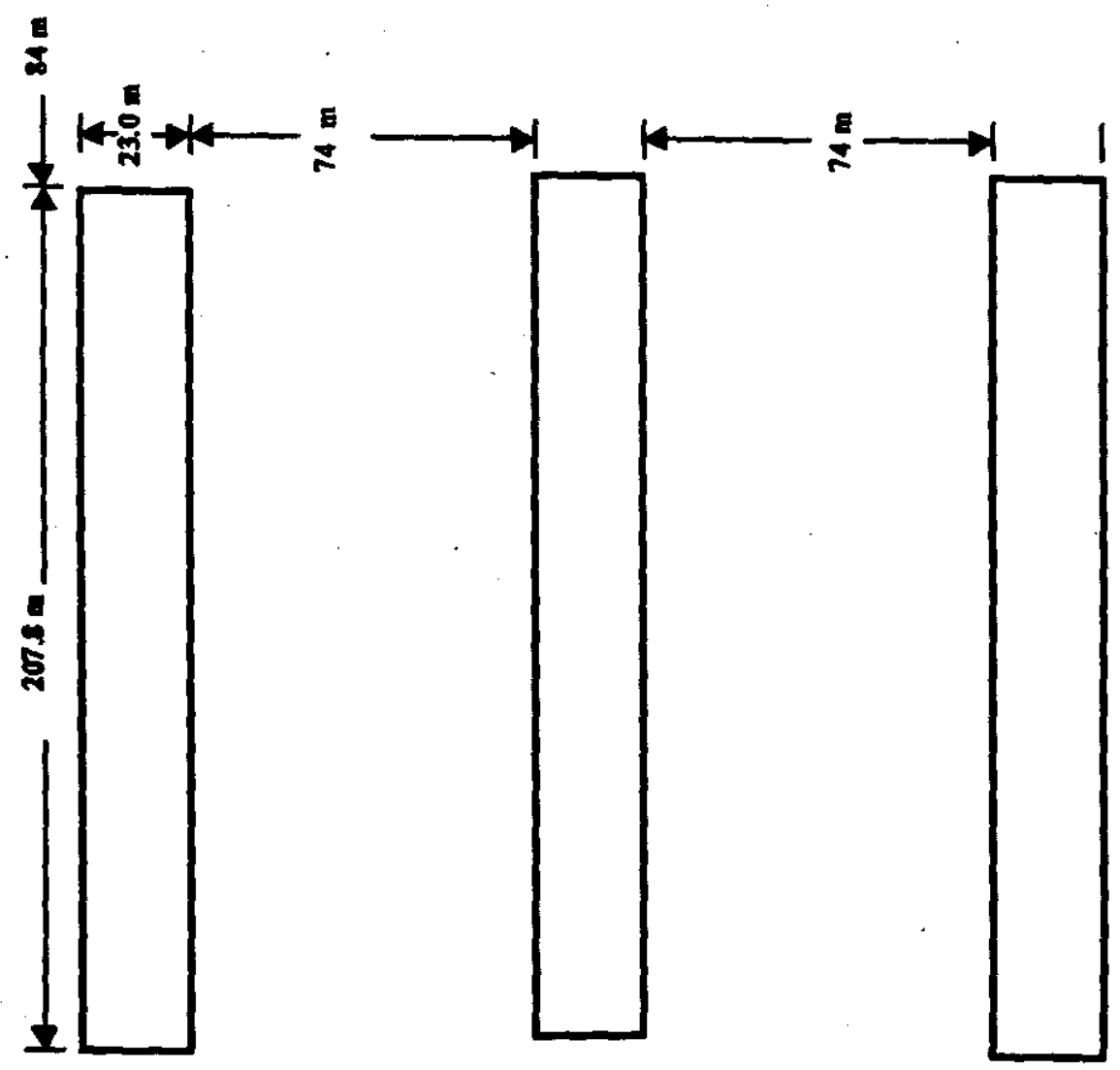




\section{DOE/ORP-2000-19, REV. 0 \\ Beferene: DOE/ORP-2000-07, REV. 0}

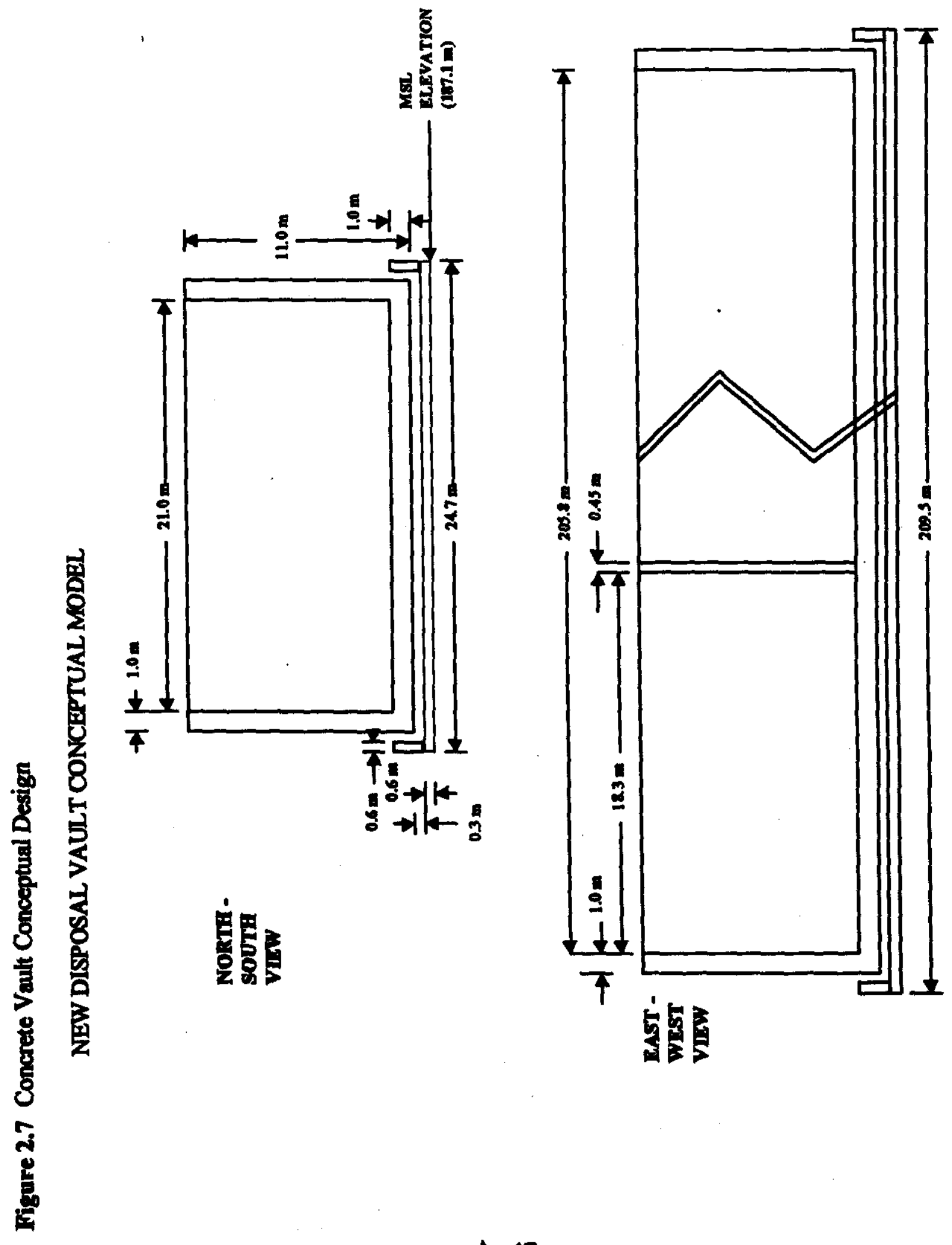


DOE/ORP-2000-19, REV. 0

Referenc: DOE/ORP-2000-07, REV. 0

This page intentionally left blank 


\section{DOE/ORP-2000-19, REV. 0 \\ Refecence: DOE/ORP-2000-07, REV. 0}

\subsection{ANALYSIS OF PERFORMANCE}

\subsection{Overview}

The analysis of performance refers to the analysis that leads to an estimate for the impact associated with the proposed disposal action. The analysis also includes information that allows the interested parties to judge the uncertainty astociated with the analysis. The 98 ILAW PA provided such an estimate for the impact associated with the proposed IIAW disposal action at that time. Since then there have been both changes in the program planning and new data obtained on parameters that impact the eventual transport of the contaminants in the waste to resources that are protected.

The analysis of performance depends on the following set of information. First, the quantity of radionuclides and hazardous chemicals must be accurately estimated. This quantity is typically referred to as the source term for potential environmental or health impacts associated with the disposal action. The pathways refer to the poasible transport routes for these radionuclides or hazardous chemicals to reach the environment and potentially impact the public. Scenario information explicitly identifies the steps by which the radionuclides and hazardous chemicals reach the public.

The quantification of the transport of the radionuclides and hazardous chemicals to the environment depends on an understanding of the transport mechanisms and interpreted parameters from field data that impact this transport. These key parameters impacting the transport are described in the section 3.4, Values and Assumptions.

The methodology for combining this information into an assessment of impact is described in the section 3.5, Performance Assessment Methodology. The methodology depends on the use of established software codes to calculate the transport. Finally, the methodology is applied to selected sensitivity cases to provide interested parties with an understanding of the relative importance of key parameters and assumptions. For a more thorough appreciation for the sensitivity of these calculations to selected parameters we will refer to the results in the 98 ILAW PA (Mann 1998a).

\subsection{Source Term}

The environmental or health impact of each radionuclide or hazardous chemical is defined as a future risk to the public and is proportional to the amount of the material at the point of impact. However, normally it is the sum of these impacts over materials at the point of impact that is important. Thus, as shown by the previous Hanford Site performance assessments (Kincaid 1995, Wood 1994, and Wood 1996), and particularly the last version of the ILAW PA (Mann 1998a), the most mobile materials have the highest impacts because they are predicted to reach the accessible environment (presumably the groundwater) within the compliance period of 1,000 to 10,000 years after disposal freility closure. Contaminants that react with the soils via sorption and precipitation remain in the vadose zone (the unsaturated region between the near surface and the unconfined aquifer) for much longer periods of time.

The latest inventory estimate for the ILAW waste is documented in the report, Immobilized Low Activity Tank Waste Imventory Data Package (Wootan 1999), and is also 


\section{DOE/ORP-2000-19, REV. 0 \\ Reference: DOE/ORP-2000-07, REV. 0}

provided as Appendix $H$ in Mann/Puigh (2000). Both radionuclides and chemicals are considered in this performance assessment. Although DOE 0435.1 only requires performance assessments for radionuclides, the Office of River Protection of DOE along with the Washington State Department of Ecology have determined that the technical analyses should support the Resource Conservation and Recovery Act (RCRA) permitting requirements as well. Thus, one technical analysis will serve as the basis for protection of the public under the requirements of the Atomic Energy Act and RCRA.

Forty-six radionuclides and twenty-five chemicals are explicitly treated in the best basis tank inventories. These materials were selected by the TWRS Characterization Program (Kupfer 1999) as those important for safety, disposal, and processing requirements. This set includes all the radionuclides identified as significant in the 1998 ILAW PA (Mann 1998a) as well as those identified in the screening studies for the ILAW PAs (Schmittroth 1995). For the chemicals identified in the 2001 ILAW PA performance objectives (Mann 1999a) that are not listed in the tank inventories, concentration limits for land disposal (40 CFR 268) were used.

The nominal ILAW inventories for all the materials explicitly included are based on the Tank Waste Remediation System Operation and Utilization Plan (Kirkbride 1999). The best basis tank-by-tank inventories (BBD) as of October 1, 1998 were adjusted for waste transfers not accounted for in the BBI, for non-BBI analytes that are in the waste treatment contract. The BBI inventories were adjusted to a common date (October 1, 1998). The BBI values are based on a tank by tank evaluation of measurements from a tank as well as modeling reaulte of transfers to and from the tank. The retrieval and feed delivery process was modeled by estimating liquid and solid partitioning (Hendrickeon 1999) and following the April 1, 1999 DOE guidance (Taylor 19996) on schedules and contract requirements. Vitrification losses (melters, stack emissions, secondary waste streams, etc.) were explicitly included in the model and are described in Kirkbride (1999). The total ILAW waste volume is estimated to be $1.581 \times 10^{5} \mathrm{~m}^{3}$. The total number of waste packages estimated to contain the projected IIAW inventory is 68,741. Kirkbride (1999) represents the IIAW project's official estimate until the BNFL, Inc. flowsheets become available.

As noted in the 1998 ILAW PA, the proviously accepted half-lives of ${ }^{79}$ Se and ${ }^{126} \mathrm{Sn}$ are now thought to be underestimates. This undereatimate for ${ }^{12} \mathrm{Sn}$ has been confirmed (Brodzinski 1998). Thus, the inventories for ${ }^{7} \mathrm{Se}$ and ${ }^{126} \mathrm{Sn}$ (as expressed in $\mathrm{Ci}$ from Kirkbride (1999)) have been reduced by a factor of 0.08 and 0.4 , respectively.

Table 3.1 provides the total inventory in the tanks and in the ILAW packages as well as the expected average and maximum concentration in the II.AW packages for each radionuclide and chemical impacting the performance objectives and goals given in Tables 1.1 and 1.2. The upper bound ILAW inventory given in Table 3.1 represents the estimated upper bound for these inventories in ILAW. The upper bound estimates are based on either contract limits (Sr, Tc, Cs, $\mathrm{Np}, \mathrm{Pu}, \mathrm{Am}$, and $\mathrm{Cm}$ ) or are taken to be the BBI tank inventories without separation. The average package concentration is calculated by dividing the total inventory for each contaminant by the number of waste packages extimated to be produced $(68,471$ packages). The maximum batch concentration is estimated from the comparison of the batch-to-batch variation in Kirkbride's (1999) flow process calculations to the average inventories in a waste package. These estimates reflect the tank-to-tank variation in inventory. For most components, the upper bound limit on total ILAW inventory was taken as the BBI tank inventory, neglecting any processing and separation losses. For radionuclides limited by the contract specifications ("Tc, 


\section{DOE/ORP-2000-19, REV. 0 \\ Referenc: DOE/ORP-2000-07, REV.0}

${ }^{137} \mathrm{Cs}$, ${ }^{90} \mathrm{Sr}$, and TRU), the contract limits were used as upper bounds. Neglecting the processing losses between the tank inventory and the ILAW inventory provides a very conservative bounding value, but was used to compensate for the lack of uncertainty information on the separations factors (wash and leach effectiveness, off-gas treatment, solids retention).

The ILAW packages must meet the land disposal restriction (LDR) treatment standards for compliance with RCRA and the Washington State Dangerous Waste Regulations contained in Chapter 173-303 of the Washington Administrative Code (WAC). The LDR regulations are found in 40 CFR 268 and WAC173-303-140. The privatization regulatory Data Quality Objectives (DQO) (Wiemers 1998) identified a set of regulatory constituents plausible to be in the tank waste and which might be considered during permitting activities in support of the treatment facility. The TWRS-P Project Dangercus Waste Permit Application (BNFL 1999) compared these constituents to the "Universal Treatment Standards" (40 CFR 268.48) and provided a list of components and LDR treatment standards. These LDR treatment standards provide an upper bound concentration for acceptability of the IIAW product. These maximum concentrations were multiplied by the total glass mass, along with a safety factor of 1.3 (assumed) to allow for uncertainty in the total glass mass, to provide bounding inventories of trace hazardous organic chemicals in the IIAW product.

The following provides short descriptions of key materials:

${ }^{3} \mathrm{H}$ No tritium is expected to survive the vitrification process to end up in ILAW packages (Kirkbride 1999).

${ }^{14} \mathrm{C} \quad \mathrm{No}^{14} \mathrm{C}$ is expected to survive the vitrification process and end up in the ILAW packages (Kirkbride 1999).

${ }^{79}$ Se Results are based on models, but are considered conservative, since the model neglects previous removals such as disposals to cribs.

${ }^{90} \mathrm{Sr}$ Values are constrained by the current contract (DOE/BNFL 1998) and assumption that this constraint applies to all ILAW waste.

${ }^{99} \mathrm{Tc}$ Values based on BBI (reference inventory) and phase 1 contract requirement (DOE/BNFL 1998) to remove $80 \%$ of tank inventory from ILAW. Calculation assumes this requirement extends to phase 2 ILAW production. Tank inventory is felt to be conservative because any losses associated with the off-site shipments are not factored into the BBI inventory for ${ }^{99} \mathrm{Tc}$.

${ }^{126} \mathrm{Sn}$ Values are based on BBI estimate with separations factor (36\% of BBI) (Kirkbride 1999). Few tank measurements for ${ }^{126} \mathrm{Sn}$ exist. The BBI estimates for ${ }^{126} \mathrm{Sn}$ in tanks 241-AZ-101 and 241-AZ-102 are higher than the measurements.

129 I Values are based on BBI and estimate for 0.25 captured and rocycled into ILAW (Kirkbride 1999).

${ }^{137}$ Cs Values are constrained by the treatment contract (DOE/BNFL 1998).

$\mathrm{U}$ Many of the values are based on total uranium analysis of samples.

$\mathrm{Ra}$ These are daughter products of uranium and thorium that were not treated correctly in the Henford Defined Waste (HDW) model because uranium, thorium, and plutonium were decayed prior to separations (Kupfer 1999). The values in Table 3.1 have been adjusted based on the Kufper (1999) estimate for tank inventory.

${ }^{227}$ AC These are daughter products of uranium and thorium that were not treated correctly in the HDW model because uranium, thorium, and plutonium were 


\section{DOE/ORP-2000-19, REV. 0 \\ Reference: DOE/ORP-2000-07, REV.0}

decayed prior to separations (Kupfer 1999). The values in Table 3.1 have been adjusted based on the Kufper (1999) estimate for tank inventory.

${ }^{229}$ Th These are daughter products of uranium and thorium that were not treated correctly in the HDW model because uranium, thorium, and plutonium were decayed prior to separations (Kupfer 1999). The values in Table 3.1 have been adjusted based on the Kupfer (1999) estimate for tank inventory.

${ }^{241} \mathrm{Am}$ The values are equal to approximately $10 \%$ of the total BBI tank inventory estimate (separations estimate from Kirkbride (1999) and are felt to be conservative

${ }^{231} \mathrm{~Pa}$ These are daughter products of uranium and thorium that were not treated correctly in the HDW model because uranium, thorium, and plutonium were decayed prior to separations (Kupfer 1999). . The values in Table 3.1 have been adjusted based on the Kufper (1999) estimate for tank inventory.

${ }^{237} \mathrm{~Np}$ Values based on BBI and large separations factor $(44 \%$ of $\mathrm{BBI}$ ) from Kirkbride (1999). BBI estimate is felt to be conservative because inventory estimate is $30 \%$ higher than the global estimate for the total produced from the reactors. Two tanks (241-AN-103 and 241-AN-105) are thought to have the $30 \%$ of the ${ }^{237} \mathrm{~Np}$, but only bounding value estimates are provided for these two tanks.

$\mathrm{Pu}$ Values are primarily based on weapons production accountability records and samples. Significant separation factors ( $5 \%$ of BBI) are taken from Kirkbride (1999).

\subsection{Pathways and Scenarios}

\subsubsection{Introduction}

Pathways define the sequence of transport steps that move the contamination from the waste form to the potential receptor for that contumination. Scenarios help define the requence of events that quantify the amount of contamination that a potential receptor may be exposed to for a given set of pathways. The selection of scenarios and pathways considerod in this white paper are based on the scenarios developed for the 2001 II.AW PA (Mann 1999b). Possible scenarios were suggested by analyzing the performance objectives given in Section 1.3 and determining which parameters could lead to exposure which is given by the performance objective. The pathways to be analyzed are groundwater, air, and inadvertent intruder. Probable natural events are identified in Section 3.3.4.

In 1992, the Hanford Future Site Uses Working Group (consisting of local, state, and federal officials, representatives of tribal nations, people from agriculture and labor, as well as members of environmental and special interest groups) was charged to determine potential future uses of the various parts of the Hanford Site. Their summary report (HFSUWG 1992-1) states:

\section{"In general, the Worling Group desires that the overall cleamup criteria for the Central Plateau should enable general usage of the land and groundwater for other than waste management activities in the horizon of 100 years from the decommissioning of waste management facilities and clasure of ditposal areas."}

The DOE along with the U.S. Department of Interior, local governments, and affected tribal nations have recently issued a comprehenaive land use plan for the Hanford Site for at least the next 50 years (DOE 1999c). The plan outlines that the 200 Areas (or Central Plateau) would be used exclusively as a waste management area.

$$
\text { A-22 }
$$


DOE/ORP-2000-19, REV. 0

Reference: DOE/ORP-2000-07, REV. 0

Table 3.1 ILAW Package Inventories (Ci for radionuclide and $\mathrm{kg}$ for chemical) and Concentrations ( $\mathrm{Ci} / \mathrm{m}^{3}$ for radionuclide and $\mathrm{kg} / \mathrm{m}^{3}$ for chemical) for important constituents

\begin{tabular}{|c|c|c|c|c|c|}
\hline Material & \begin{tabular}{|l|} 
Tank \\
Inventory
\end{tabular} & \begin{tabular}{|l|} 
IIAW \\
Inventory
\end{tabular} & $\begin{array}{l}\text { Upper Bound } \\
\text { ILAW } \\
\text { Inventory }\end{array}$ & $\begin{array}{l}\text { Average } \\
\text { Package } \\
\text { Concentration }\end{array}$ & $\begin{array}{l}\text { Maximum Batch } \\
\text { Concentration }\end{array}$ \\
\hline $3-\mathrm{H}$ & $2.46 \mathrm{E}+04$ & $0.00 \mathrm{E}+00$ & $2.46 \mathrm{E}+04$ & $0.00 E+00$ & $0.00 \mathrm{E}+00$ \\
\hline $14-C$ & $4.38 \mathrm{E}+03$ & $0.00 \mathrm{E}+00$ & $4.38 E+03$ & $0.00 E+00$ & $0.00 \mathrm{E}+00$ \\
\hline $59-\mathrm{Ni}$ & $8.58 \mathrm{E}+02$ & $1.67 E+02$ & $8.58 \mathrm{E}+02$ & $1.06 \mathrm{E}-03$ & $4.02 \mathrm{E}-03$ \\
\hline $60-\mathrm{Co}_{0}$ & $1.99 \mathrm{E}+04$ & $4.18 E+03$ & $1.99 \mathrm{E}+04$ & $2.64 \mathrm{E}-02$ & $3.07 \mathrm{E}-01$ \\
\hline 63-Ni & $8.45 \mathrm{E}+04$ & $1.62 E+04$ & $8.45 \mathrm{E}+04$ & $1.02 \mathrm{E}-01$ & $3.91 \mathrm{E}-01$ \\
\hline 79-Se & $5.74 \mathrm{E}+01$ & $4.80 \mathrm{E}+01$ & $9.32 \mathrm{E}+02$ & $3.03 \mathrm{E}-04$ & $6.84 \mathrm{E}-02$ \\
\hline $90-\mathrm{Sr}^{(a)}$ & $5.99 E+07$ & $4.50 \mathrm{E}+06$ & $5.85 E+06$ & $2.85 E+01$ & $5.43 \mathrm{E}+01$ \\
\hline $93-\mathrm{Zr}$ & $4.12 E+03$ & $1.25 E+03$ & $4.12 E+03$ & $7.94 \mathrm{E}-03$ & $3.37 \mathrm{E}-02$ \\
\hline $93 \mathrm{~m}-\mathrm{Nb}$ & $2.53 \mathrm{E}+03$ & $8.36 \mathrm{E}+02$ & $2.53 \mathrm{E}+03$ & $5.29 \mathrm{E}-03$ & $4.47 \mathrm{E}-02$ \\
\hline 99-Tc & $2.89 \mathrm{E}+04$ & $5.79 \mathrm{E}+03$ & $6.65 \mathrm{E}+03$ & $3.66 \mathrm{E}-02$ & $9.96 \mathrm{E}-02$ \\
\hline $106-\mathrm{Ru}$ & $1.27 E+05$ & $8.94 \mathrm{E}+02$ & $1.27 \mathrm{E}+05$ & $5.65 \mathrm{E}-03$ & $2.59 \mathrm{E}-01$ \\
\hline $113 \mathrm{~m}-\mathrm{Cd}$ & $1.67 \mathrm{E}+04$ & $7.97 \mathrm{E}+03$ & $1.67 \mathrm{E}+04$ & $5.04 \mathrm{E}-02$ & $2.14 \mathrm{E}-01$ \\
\hline $125-\mathrm{Sb}$ & $2.47 \mathrm{E}+05$ & $5.20 \mathrm{E}+04$ & $2.47 \mathrm{E}+05$ & $3.29 \mathrm{E}-01$ & $6.50 \mathrm{E}+00$ \\
\hline $126-S n$ & $4.64 \mathrm{E}+02$ & $1.69 \mathrm{E}+02$ & $1.16 \mathrm{E}+03$ & $1.07 \mathrm{E}-03$ & $1.04 \mathrm{E}-02$ \\
\hline $129-I$ & $1.01 \mathrm{E}+02$ & $2.20 \mathrm{E}+01$ & $1.01 \mathrm{E}+02$ & $1.39 \mathrm{E}-04$ & $1.81 \mathrm{E}-03$ \\
\hline $134-\mathrm{Cs}_{\mathrm{s}}$ & $8.71 \mathrm{E}+04$ & $3.76 \mathrm{E}+02$ & $4.89 \mathrm{E}+02$ & $3.73 \mathrm{E}-01$ & $1.35 \mathrm{E}+01$ \\
\hline $137-\mathrm{Cs}^{\left({ }^{(B)}\right.}$ & $6.37 \mathrm{E}+07$ & $9.11 \mathrm{E}+05$ & $1.18 \mathrm{E}+06$ & $5.76 \mathrm{E}+00$ & $7.80 \mathrm{E}+00$ \\
\hline $151-\mathrm{Sm}$ & $2.61 \mathrm{E}+06$ & $7.80 \mathrm{E}+05$ & $2.61 \mathrm{E}+06$ & $4.93 \mathrm{E}+00$ & $2.42 \mathrm{E}+01$ \\
\hline 152-Eu & $1.45 E+03$ & $3.07 \mathrm{E}+02$ & $1.45 \mathrm{E}+03$ & $1.94 \mathrm{E}-03$ & $4.21 \mathrm{E}-02$ \\
\hline 154-Eu & $1.83 E+05$ & $3.77 \mathrm{E}+04$ & $1.83 E+05$ & $2.38 \mathrm{E}-01$ & $6.13 E+00$ \\
\hline $155-\mathrm{Eu}$ & $1.76 \mathrm{E}+05$ & $3.15 \mathrm{E}+04$ & $1.76 \mathrm{E}+05$ & $1.99 \mathrm{E}-01$ & $7.36 \mathrm{E}+00$ \\
\hline $226-\mathrm{Ra}^{(0)}$ & $6.31 \mathrm{E}-02$ & $5.70 \mathrm{E}-02$ & $1.14 \mathrm{E}+03$ & $3.61 \mathrm{E}-07$ & $1.56 \mathrm{E}-05$ \\
\hline $227-A C^{(0)}$ & $8.76 \mathrm{E}+01$ & $6.06 \mathrm{E}-02$ & $8.75 E+01$ & $3.83 \mathrm{E}-07$ & $1.76 \mathrm{E}-06$ \\
\hline $228-\mathbf{R}^{(0)}$ & 7.71E+01 & $3.30 \mathrm{E}+01$ & $7.75 \mathrm{E}+01$ & 2.09E-04 & $1.06 \mathrm{E}-03$ \\
\hline 229-Th ${ }^{(0)}$ & $1.81 E+00$ & $3.40 \mathrm{E}-0 \mid$ & $1.81 \mathrm{E}+\infty 0$ & 2.15E-06 & $1.14 \mathrm{E}-05$ \\
\hline $231-\mathrm{Pa}^{(0)}$ & $1.56 \mathrm{E}+02$ & $3.44 \mathrm{E}-0$ & $1.53 E+02$ & $2.17 \mathrm{E}-06$ & $1.05 \mathrm{E}-05$ \\
\hline 232-Th & $4.40 \mathrm{E}+00$ & $1.28 \mathrm{E}+06$ & $4.40 \mathrm{E}+\infty 0$ & $8.09 \mathrm{E}-06$ & $5.97 \mathrm{E}-05$ \\
\hline $232-U$ & $1.49 \mathrm{E}+02$ & $3.46 \mathrm{E}+01$ & $1.49 \mathrm{E}+02$ & $2.19 \mathrm{E}-04$ & $1.64 \mathrm{E}-03$ \\
\hline $233-\mathrm{U}$ & $5.72 E+02$ & $1.31 \mathrm{E}+02$ & $5.72 \mathrm{E}+02$ & $8.26 \mathrm{E}-04$ & $6.22 \mathrm{E}-03$ \\
\hline $234-\mathrm{U}$ & $3.42 \mathrm{E}+02$ & $4.41 \mathrm{E}+0$ & $3.42 \mathrm{E}+02$ & $2.79 \mathrm{E}-04$ & $1.95 \mathrm{E}-03$ \\
\hline $235-\mathrm{U}$ & $1.46 \mathrm{E}+01$ & $1.79 \mathrm{E}+00$ & $1.46 \mathrm{E}+01$ & $1.13 \mathrm{E}-05$ & $7.97 \mathrm{E}-05$ \\
\hline $236-U$ & $1.24 \mathrm{E}+01$ & $1.43 \mathrm{E}+0.0$ & $1.24 \mathrm{E}+01$ & $9.03 \mathrm{E}-06$ & $3.68 \mathrm{E}-05$ \\
\hline $237-N_{p}$ & $1.85 \mathrm{E}+02$ & $8.10 \mathrm{E}+01$ & $3.00 E+02$ & $5.13 \mathrm{E}-04$ & $1.78 \mathrm{E}-03$ \\
\hline 238-Pu & $2.70 \mathrm{E}+03$ & $1.06 \mathrm{E}+\infty 2$ & $3.94 E+02$ & $6.72 \mathrm{E}-04$ & $2.69 \mathrm{E}-03$ \\
\hline 238-U & $3.28 E+02$ & $4.83 E+01$ & $3.28 \mathrm{E}+02$ & $3.06 \mathrm{E}-04$ & $2.02 \mathrm{E}-03$ \\
\hline 239-Pu & $5.55 \mathrm{E}+04$ & $3.05 \mathrm{E}+03$ & $1.13 \mathrm{E}+04$ & $1.93 \mathrm{E}-02$ & $9.50 \mathrm{~B}-02$ \\
\hline $240-\mathrm{Pu}$ & $1.13 E+04$ & $5.25 \mathrm{E}+\infty 2$ & $1.95 \mathrm{E}+03$ & $3.32 \mathrm{E}-03$ & $1.34 \mathrm{E}-02$ \\
\hline $241-\mathrm{Am}$ & $1.07 E+05$ & $1.08 \mathrm{E}+04$ & $4.01 E+04$ & $6.85 \mathrm{E}-02$ & $1.69 \mathrm{E}+00$ \\
\hline $241-\mathrm{Pu}$ & $1.66 \mathrm{E}+05$ & $7.17 \mathrm{E}+03$ & $1.66 \mathrm{E}+05$ & $4.53 \mathrm{E}-02$ & $1.98 \mathrm{E}-01$ \\
\hline $242-\mathrm{Cm}$ & $1.72 E+02$ & $5.76 \mathrm{E}+01$ & $1.72 E+02$ & $3.64 \mathrm{E}-04$ & $1.16 \mathrm{~B}-02$ \\
\hline 242-Pu & $1.07 \mathrm{E}+\infty$ & $4.49 \mathrm{E}-02$ & $1.66 \mathrm{E}-01$ & $2.84 \mathrm{E}-07$ & $1.69 \mathrm{E}-06$ \\
\hline 243-Am & $1.76 \mathrm{E}+01$ & $6.89 \mathrm{E}-01$ & $2.55 \mathrm{E}+00$ & $4.36 \mathrm{E}-06$ & 9.01E-05 \\
\hline
\end{tabular}


DOE/ORP-2000-19, REV. 0

Refrence: DOE/ORP-2000-07, REV. 0

\begin{tabular}{|c|c|c|c|c|c|}
\hline Material & \begin{tabular}{|l} 
Tank \\
Inventory
\end{tabular} & $\begin{array}{l}\text { IIAW } \\
\text { Inventory }\end{array}$ & $\begin{array}{l}\text { Upper Bound } \\
\text { ILAW } \\
\text { Inventory }\end{array}$ & \begin{tabular}{|l|} 
Average \\
Package \\
Concentration
\end{tabular} & $\begin{array}{l}\text { Maximum Batch } \\
\text { Concentration }\end{array}$ \\
\hline $243-\mathrm{Cm}$ & $3.47 \mathrm{E}+01$ & $6.73 \mathrm{E}+00$ & $2.49 \mathrm{E}+01$ & $4.26 \mathrm{E}-05$ & $5.18 \mathrm{E}-04$ \\
\hline $244-\mathrm{Cm}$ & $7.84 \mathrm{E}+02$ & $1.01 \mathrm{E}+02$ & $3.73 \mathrm{E}+02$ & $6.36 \mathrm{E}-04$ & $6.77 \mathrm{E}-03$ \\
\hline Agt (Silver) & $1.51 \mathrm{E}+03$ & $1.08 \mathrm{E}+02$ & $3.03 \mathrm{E}+03$ & $6.83 \mathrm{E}-04$ & $5.68 \mathrm{E}-03$ \\
\hline Ast5 (Arsenic) & $2.08 \mathrm{E}+01$ & $1.76 \mathrm{E}+01$ & $4.15 \mathrm{E}+01$ & $1.12 \mathrm{E}-04$ & $7.42 \mathrm{E}-03$ \\
\hline Ba+2 (Barium) & $1.70 \mathrm{E}+03$ & $1.86 \mathrm{E}+01$ & $3.39 \mathrm{E}+03$ & $1.17 \mathrm{E}-04$ & $7.24 \mathrm{E}-03$ \\
\hline Be+2 (Beryllium) & $1.09 \mathrm{E}+02$ & $6.14 \mathrm{E}-01$ & $2.18 \mathrm{E}+02$ & $3.89 \mathrm{E}-06$ & $5.48 \mathrm{E}-04$ \\
\hline 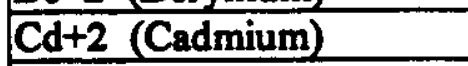 & $4.18 \mathrm{E}+02$ & $6.30 \mathrm{E}+01$ & $8.36 \mathrm{E}+02$ & $3.98 \mathrm{E}-04$ & $5.13 \mathrm{E}-03$ \\
\hline Cl- (Chlorine) & $9.37 \mathrm{E}+05$ & $9.31 \mathrm{E}+05$ & $9.37 \mathrm{E}+05$ & $5.89 \mathrm{E}+00$ & $1.55 \mathrm{E}+01$ \\
\hline CN- (Cyanide) & $1.09 \mathrm{E}+05$ & $0.00 \mathrm{E}+00$ & $1.09 \mathrm{E}+05$ & $0.00 \mathrm{E}+00$ & $0.00 \mathrm{E}+00$ \\
\hline $\mathrm{Cr}$ (TOTAL)(Chromium) & $6.72 \mathrm{E}+05$ & $2.74 \mathrm{E}+05$ & $6.72 \mathrm{E}+05$ & $1.73 \mathrm{E}+00$ & $1.27 \mathrm{E}+01$ \\
\hline Cu+2 (Copper) & $3.15 E+02$ & $7.33 \mathrm{E}-01$ & $6.31 \mathrm{E}+02$ & $4.63 \mathrm{E}-06$ & $2.54 \mathrm{E}-05$ \\
\hline F- (Fluoride) & $1.20 \mathrm{E}+06$ & $9.94 \mathrm{E}+05$ & $1.20 \mathrm{E}+06$ & $6.28 \mathrm{E}+00$ & $2.75 \mathrm{E}+01$ \\
\hline Fe+3 (Iron) & $1.40 \mathrm{E}+06$ & $4.48 \mathrm{E}+04$ & $1.40 \mathrm{E}+06$ & $2.83 \mathrm{E}-01$ & $2.86 \mathrm{E}+00$ \\
\hline $\mathrm{Hg}+2$ (Mercury) & $2.10 \mathrm{E}+03$ & $1.92 \mathrm{E}+02$ & $2.10 \mathrm{E}+03$ & $1.22 \mathrm{E}-03$ & $3.38 \mathrm{E}-02$ \\
\hline Mn+4 (Manganese) & $1.96 \mathrm{E}+05$ & $1.38 \mathrm{E}+04$ & $1.96 \mathrm{E}+05$ & $8.71 \mathrm{E}-02$ & $4.20 \mathrm{E}-01$ \\
\hline NH3 (Ammonia) & $5.01 \mathrm{E}+05$ & $0.00 \mathrm{E}+00$ & $5.01 \mathrm{E}+05$ & $2.53 \mathrm{E}+00$ & $4.24 \mathrm{E}+01$ \\
\hline Ni+2 (Nickel) & $1.80 \mathrm{E}+05$ & $3.05 \mathrm{E}+04$ & $1.80 \mathrm{E}+05$ & $1.93 \mathrm{E}-01$ & $2.96 \mathrm{E}+00$ \\
\hline NO2- (Nitrate) & $1.26 \mathrm{E}+07$ & $0.00 \mathrm{E}+00$ & $1.26 \mathrm{E}+07$ & $0.00 \mathrm{E}+00$ & $0.00 \mathrm{E}+00$ \\
\hline NO3- (Nitrite) & $5.25 \mathrm{E}+07$ & $0.00 \mathrm{E}+00$ & $5.25 \mathrm{E}+07$ & $0.00 \mathrm{E}+00$ & $0.00 \mathrm{E}+00$ \\
\hline $\mathrm{Pb}+2$ (Lead) & $8.40 \mathrm{E}+04$ & $7.83 E+03$ & $8.40 \mathrm{E}+04$ & $4.95 \mathrm{E}-02$ & $2.73 \mathrm{E}-01$ \\
\hline Set6 (Selenium) & $6.11 \mathrm{E}-01$ & $5.33 \mathrm{E}-01$ & $1.22 \mathrm{E}+\infty$ & $3.37 \mathrm{E}-06$ & $2.96 \mathrm{E}-05$ \\
\hline SO4-2 (Sulfate) & $3.91 \mathrm{E}+06$ & $3.39 \mathrm{E}+06$ & $3.91 \mathrm{E}+06$ & $2.15 \mathrm{E}+01$ & $9.12 \mathrm{E}+01$ \\
\hline T1+3 (Thallium) & $2.54 \mathrm{E}+04$ & NA & $5.08 \mathrm{E}+04$ & $0.00 \mathrm{E}+\infty$ & $0.00 \mathrm{E}+00$ \\
\hline $\mathrm{Zn+2}$ (Zinc) & $2.89 \mathrm{E}+03$ & $1.98 \mathrm{E}+03$ & $5.79 \mathrm{E}+03$ & $1.25 \mathrm{E}-02$ & $1.19 \mathrm{E}-01$ \\
\hline U (TOTAL) (Uranium) ${ }^{(a)}$ & $7.61 E+04$ & $1.73 E+04$ & $7.61 \mathrm{E}+04$ & $1.11 \mathrm{E}-01$ & $2.16 \mathrm{E}+\infty 0$ \\
\hline 1,1,1-trichlorethane ${ }^{(0)}$ & NA & $0.00 \mathrm{E}+00$ & $9.17 E+02$ & $0.00 \mathrm{E}+00$ & $0.00 \mathrm{E}+00$ \\
\hline 1,1,2-trichloroethane (0) & NA & $0.00 E+00$ & $9.17 \mathrm{E}+02$ & $0.00 \mathrm{E}+00$ & $0.00 \mathrm{E}+00$ \\
\hline benzene (0) & NA & $0.00 \mathrm{E}+00$ & $1.53 \mathrm{E}+03$ & $0.00 \mathrm{E}+00$ & $0.00 \mathrm{E}+00$ \\
\hline carbon tetrachloride () & NA & $0.00 \mathrm{E}+00$ & $9.17 e+02$ & $0.00 \mathrm{E}+\infty 0$ & $0.00 \mathrm{E}+\infty$ \\
\hline chloroform (0) & $\sqrt{\mathrm{NA}}$ & $0.00 \mathrm{E}+00$ & $9.17 \mathrm{E}+02$ & $0.00 \mathrm{E}+00$ & $0.00 \mathrm{E}+00$ \\
\hline ethyl benzene (O) & NA & $0.00 \mathrm{E}+00$ & $1.53 \mathrm{E}+03$ & $0.00 \mathrm{E}+00$ & $0.00 \mathrm{E}+00$ \\
\hline methylene chloride (0) & NA & $0.00 \mathrm{E}+00$ & $4.59 \mathrm{E}+03$ & $0.00 \mathrm{E}+00$ & $0.00 \mathrm{E}+\infty 0$ \\
\hline n-butyl alcohol ${ }^{\mathrm{O}}$ & NA & $0.00 \mathrm{E}+00$ & $3.98 \mathrm{e}+02$ & $0.00 \mathrm{E}+\infty 0$ & $0.00 \mathrm{E}+00$ \\
\hline toluene ${ }^{(0)}$ & NA & $0.00 \mathrm{E}+00$ & $1.53 \mathrm{E}+03$ & $0.00 \mathrm{E}+00$ & $0.00 \mathrm{E}+00$ \\
\hline $\begin{array}{l}\text { trichloroethylene (1,1,2- } \\
\text { Trichloroehylene) }\end{array}$ & NA & $0.00 \mathrm{E}+00$ & $9.17 \mathrm{E}+02$ & $0.00 \mathrm{E}+00$ & $0.00 \mathrm{E}+00$ \\
\hline $\begin{array}{l}\text { xylenes-mixed isomers } \\
\text { (sum of m-, } 0-\text {, and p- } \\
\text { Xylene) }\end{array}$ & NA & $0.00 \mathrm{E}+00$ & \begin{tabular}{l|l}
$5.59 E+03$
\end{tabular} & $0.00 \mathrm{E}+00$ & $0.00 \mathrm{E}+\infty 0$ \\
\hline 1,4-dichlorobenzene? & NA & $0.00 \mathrm{E}+00$ & \begin{tabular}{l|l}
$0.17 \mathrm{E}+02$ \\
\end{tabular} & $0.00 \mathrm{E}+00$ & $0.00 \mathrm{E}+00$ \\
\hline
\end{tabular}

(C) The "Sr will have " $\mathrm{Y}$ daughter in equilibrium

(B) The ${ }^{137} \mathrm{Cs}$ will have ${ }^{137} \mathrm{Ba}$ daughter in equilibrium

(0) The values in Table 3.1 have been adjusted based on the Kufper (1999) estimate for tank inventory. Inventories for radionuclides are as of 10/1/98. 


\section{DOE/ORP-2000-19, REV. 0 \\ Reference: DOE/ORP-2000-07, REV.0}

(d) Total uranium = total uranium - radioactive inventory.

(c) tank inventories of specific organic compounds are not available; organic compounds are not expected to survive the vitrification process. NA entries refer to components where inventory information is not available.

Except for the inadvertent intruder scenario, the scenarios described here assume that some controls remain in place to prevent public intrusion into the disposal site. That is, the barriers and markers that have been left are effective in preventing open use of the land directly over the dispoșal site.

\subsubsection{Pathways}

\subsubsection{Groundwater}

Past Hanford Site performance assessments (see Kincaid 1995, Mann 1998a, Wood 1994, and Wood 1996) have shown the groundwater pathway to be the most restrictive for the vast majority of radionuclides. Previous assessments have not analyzed the effect of chemicals. Figure 3.1 shows the details of the groundwater pathway. The eight steps are:

1) Precipitation (rain or snow) falls on the ground with much of the water returned to the atmosphere due to evaporation or transpiration through plant leaves. The remaining water infiltrates the soil below the surface at a very low rate.

2) The water moves downward, but some of the water is diverted by an intact sand-gravel capillary break.

3) The water that is not diverted away fron the waste may be chemically modified by the local environment, interacts with the waste form, and accumulates contaminants.

4) The water (possibly a reduced ampunt because waste form dissolution and mineral formation consumes water) leaves the disposal facility carrying contaminants with it. Some contaminants may interact with the material in the disposal facility, slowing the release of contaminants to the surrounding natural environment.

5) Contaminated water moves through the undisturbed, unsaturated zone (vadose zone) below the disposal facility down to the unconfined aquifer. The contaminants may interact with soil sediments causing further retardation. Changes to the properties of the natural system are considered, but are not a major impact on the analysis results.

6) The water and contaminants move and mix with the water in the unconfined aquifer until they are extracted from the aquifer and brought to the surface or until they reach the Columbia River.

7) Contaminants are extracted by being carried to the surface with groundwater being pumped from a well.

8) The contaminants result in human exposure through a variety of exposure pathways (ingestion, inhalation, dermal contact, und external radiation) and exposure scenarios (agricultural, Native American, etc.).

$$
\text { A- } 25
$$


DOE/ORP-2000-19, REV. 0

Reference: DOE/ORP-2000-07, REV.0

Figure 3.1 Eight Sequential Steps for the Groundwater Pathway

1) Water starts downward journey from the near-surface region.

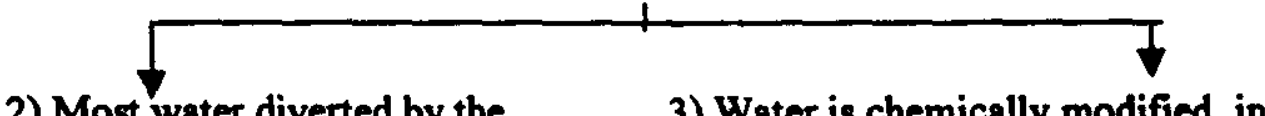

2) Most water diverted by the

3) Water is chemically modified, interacts with disposal system barrier. waste form, and accumulates contaminants.

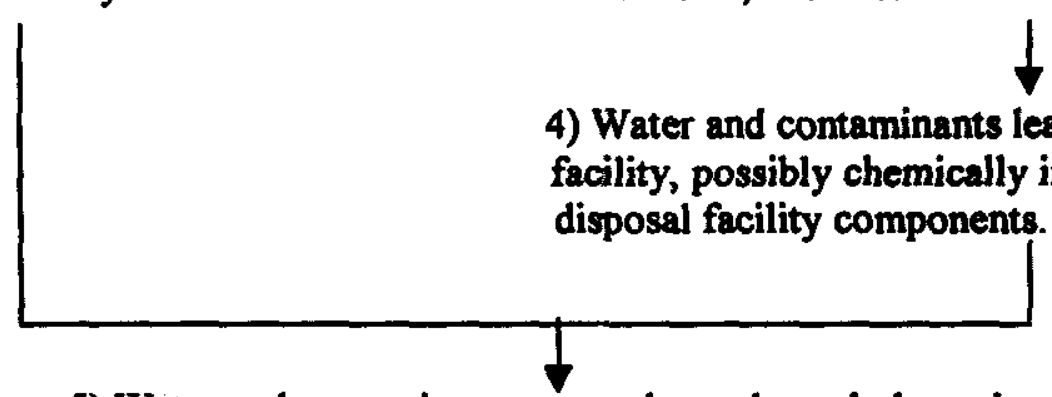

$\downarrow$

5) Water and contaminants move down through the vadose zone.<smiles>C1C[Te]1</smiles>

6) The contaminants move downgradient in the unconfined aquifer, mixing with the groundwater, diluting the contaminant concentration.<smiles></smiles>

7) Water and contaminants are pumped from a well to surface

8) Humans receive exposure from contaminants.

Even though the most mobile radionuclides had peaked much earlier, the 1998 ILAW PA (Mann 1998a) showed that the second most mobile radiomuclides (such as uranium and its daughters) peaked at about 50,000 years, a time at which the most mobile radionuclides (technetium and selenium) were still significart. Explicit numerical simulations will be performed from the present to 20,000 years in the future (1.e., twice the time for the NRC time of compliance) using best-estimate or conservative values for all parameters. Comparisons to the performance objectives will be made at 1,000 years and at 10,000 years after closure of the IIAW disposal facility (which is assumed to be in 2030).

\subsubsection{Air}

The air pathway is associated with the diffusion of radioactive or hazardous gases from the disposal facility to the surface where potential individuals or groups are at risk. The previous performance assessment (Mann 1998a) showed that using conservative assumptions, releases to the atmosphere are many orders of magnitude (four in the case of radon releases and nine for other gases) less than performance objectives, As in the 1998 IIAW PA, diffusion of gaseous species has been addressed. The buildup of ${ }^{2 t} \mathrm{Rn}$ from uranium isotopes is included in the analysis. 


\section{DOE/ORP-2000-19, REV. 0 \\ Reference: DOE/ORP-2000-07, REV. 0}

\subsubsection{Inadvertent Intruder}

The inadvertent intruder pathway is associated with the excavation of waste from the disposal site onto the surface where it is available to expose individuals or groups at risk.

\subsubsection{Scenarios}

\subsubsection{Exposure Scenarios}

Two major exposure scenarios are considered: drinking contaminated water and living on a small farm. The details of these scenarios and the justification for all the parameters used in them are in Rittmann (1999). The simplest case is exposure to contaminated drinking water pumped from a well. This well is assumed to be no closer to the disposal facility than $100 \mathrm{~m}$ (328 ft) and to be located to provide the maximum groundwater concentrations of contaminants. The two major exposure parameters in this scenario are the amount of water consumed and the suite of dose conversion factors used.

The more complex scenario has a person not only drinking the well water, but also using it to irrigate a small farm. Exposure comes from drinking contaminated water, ingesting contaminated food (meat, vegetables, etc.), ingesting and inhaling contaminated soil, and from direct irradiation from the contaminated soil. The total exposure results in the all-pathways dose.

\subsubsection{Inadvertent Intruder}

Following the practice of the Nuclear Regulatory Commission (NRC 1988, NRC 1997), three scenarios were considered:

- A basement is excavated which extends into the waste and hence contaminants are brought to the surface

- A well is drilled through the waste, bringing contaminants to the surface,

- Contaminants that have been brought to the surface are mixed with the surrounding soil as a residential farmer works the soil.

Because the waste will be below ( $>5$ meters) the levels that basement excavations are dug in the Columbia Basin region, the first scenario (basement excavation) is not treated. The other two scenarios are treated.

\subsubsection{Natural Events}

The main natural events to be expected are: 1) erosion of the surface above the disposal units due to wind, 2) subsidence of the engineered barriers or facilities, 3) earthquakes, and 4) flooding due to post-glacial ovents. The analyses conducted for the 1998 ILAW PA will be used to estimate the impacts of these main natural events. 


\section{DOE/ORP-2000-19, REV. 0 \\ Referenc: DOE/ORP-2000-07, REV. 0}

\subsection{Values and Assumptions}

This section provides a description of the conceptual models and data for those models that were used in the analyses. It covers the selection criteria and key assumptions for the conceptual models; describes the models and their associated data, the waste form, release rate, disposal facility, and moisture and moisture infiltration rate. It also covers the dosimetry parameters. The numerical models actually used in the computer simulations were based upon these conceptual models and are described in Section 3.5.

\subsubsection{Key Assumptions}

Even though the current site-, facility-, and waste form-specific data needed for a performance assessment are incomplete, enough relevant data from other sources are known about the proposed disposal action that reasonable assumptions can be made. The key assumptions are in following areas:

- Layout of the disposal facilities (which dictates geology, stratigraphy, infiltration rate, and associated parameters)

- Waste form (which influences the release rate of contaminants)

- Inventory

- Disposal facility design.

The location for the new disposal facility action has been decided. However, determining the layout of the facilities on the reserved land is just beginning. Only limited characterization has been performed at this site. However, the central plateau area in which the preferred site rests has been well characterized. Therefore, rather good assumptions can be made about parameters that describe the proposed disposal site. A borehole (299-E17-20) just southwest of the new disposal site has been drilled to the underlying basalt layer at about $122 \mathrm{~m}(400 \mathrm{ft})$ with respect to mean sea level. Both the borehole itself and samples taken from it have undergone significant characterization (Reidel 1997). These data have been incorporated into this analysis (Mann/Puigh [2000 - Appendices G, L, M, and N]).

The final waste form has not been determined, and, in fact, probably will change as wastes from different tanks are retrieved. BNFL, Inc. has identified preliminary compositions and processing steps for its production. Limited testing has been performed on BNFL, Inc. relevant glasses (McGrail 1999). The data obtained from the testing of the glass composition LAWABP1 (which is the most studied glass in the composition space of interest to BNFL, Inc.) will be used in the base analysis case.

The actual composition of the waste form (both radioactive and non-radioactive) has not been finalized. For these analyses, only the mean composition based on the estimated total radionuclide and hazardous material inventory was used. As retrieval scenarios are better defined and individual tank contents become beter known, composition variations in the waste form will be determined. These variations will ye used in the future analyses. An estimate for the uncertainty in the inventory estimates is provided in (Wootan 1999).

Finally, only conceptual ideas exist for the current facility design (See Mann/Puigh Appendix 1). The base analysis case calculation will be based on the conceptual design work for 


\section{DOE/ORP-2000-19, REV. 0 \\ Reference: DOE/ORP-2000-07, REV. 0}

the remote handled trench described in Puigh (1999). A sensitivity case will be run using the geometry of the concrete vaults at the ILAW disposal location (Pickett 1998).

\subsubsection{Site}

This section translates the geology, hydrogeology, and geochemistry described in Mann/Puigh (2000) into a conceptual model and values that can be used in the analyses supporting this performance assessment. The location and stratigraphy of the disposal site are discussed first. Next, the hydrologic and geochemical properties of the vadose zone are addressed. Finally, the properties and structural features of the unconfined aquifer are examined.

\subsubsection{Location and Stratigraphy}

As noted in Section 2.0 of this report, the location of the disposal facility was determined (Rutherford 1997) to be in the south central part of the 200 East Area. The main strata at this location are the Hanford formation and the Ringold Formation.

The geology of the ILAW disposal site is given in Geologic Data Package for the 2001 ILAW PA (Reidel 1999) which is attached as Appendix $G$ to Mann/Puigh (2000). The Hanford Site lies in the Pasco Basin of the Columbia Plateau. The Columbia Plateau consists of a sequence of thick basalt flows that occurred 4 to 15 million years ago. Overlying the basalt flows are sediments of the late Miocene, Pliocene, and Pleistocene ages, known as the Ringold Formation and (nearer the surface) the Hanford formation. The Hanford formation arises from deposits from post-glacier flooding $(-13,000$ years ago $)$ and consists mainly of unconeolidated sand and sandy gravel layers. The unconfined equifer is near the interface between the Hanford formation and Ringold Formation throughout the Hanford Site and at the ILAW disposal site is about 103 meters ( 338 feet) below the surface. Clastic dikes have been observed at the Hanford Site and are assumed to exist at the new ILAW site as well.

The stratigraphy at the ILAW disposal site has the top of the Columbia River Basalt Group at an elevation (above sea level) of approximately $84 \mathrm{~m}(275 \mathrm{ft}$ ). The top of the Ringold Formation ranges between 91-122 m (300-400 A) (north to south). The Hanford formation gravel sequence thickness is approximately $27-46 \mathrm{~m}(88-150 \mathrm{ft})$ thick (south to north); and the Hanford formation sand sequence varies from 44 to $76 \mathrm{~m}$ (210-250 ft) (north to south). Within the sandy sequence three paleosols were identified from borehole 299-E17-21 (Reidel 1998). Paleosol Horizon 1 occurs at $49 \mathrm{~m}$ (163 ft) drilled depth, paleosol Horizon 2 occurs at $18 \mathrm{~m}$ (58 f) drilled depth, and paleosol Horizon 3 occurs at $1.5 \mathrm{~m}(5 \mathrm{ft})$ drilled depth. These paleosol horizons are as much as $15 \mathrm{~cm}$ (6 in) with a shurp upper surface interface. Finally, Eolian deposits cover the southern part of the new ILAW disposal site and range in thickness between 3 to $15 \mathrm{~m}(10-50 \mathrm{ft})$ (south to north). The current water table is in the Hanford formation gravel sequence below most of the new disposal site. See Figure 3.2 for a representative stratigraphy for the ILAW disposal site.

\subsubsection{Hydrologic Parameters}

Hydrologic processes describe how moisture moves through the subsurface. Because there are distinct regions associated with subsarface flow and transport at the ILAW disposal site, the system has been divided into three parts: near-field, far-field, and groundwater. 
DOE/ORP-2000-19, REV. 0

Reference: DOE/ORP-2000-07, REV. 0

Figure 3.2 Stratigraphy for the ILAW Disposal Site

ต
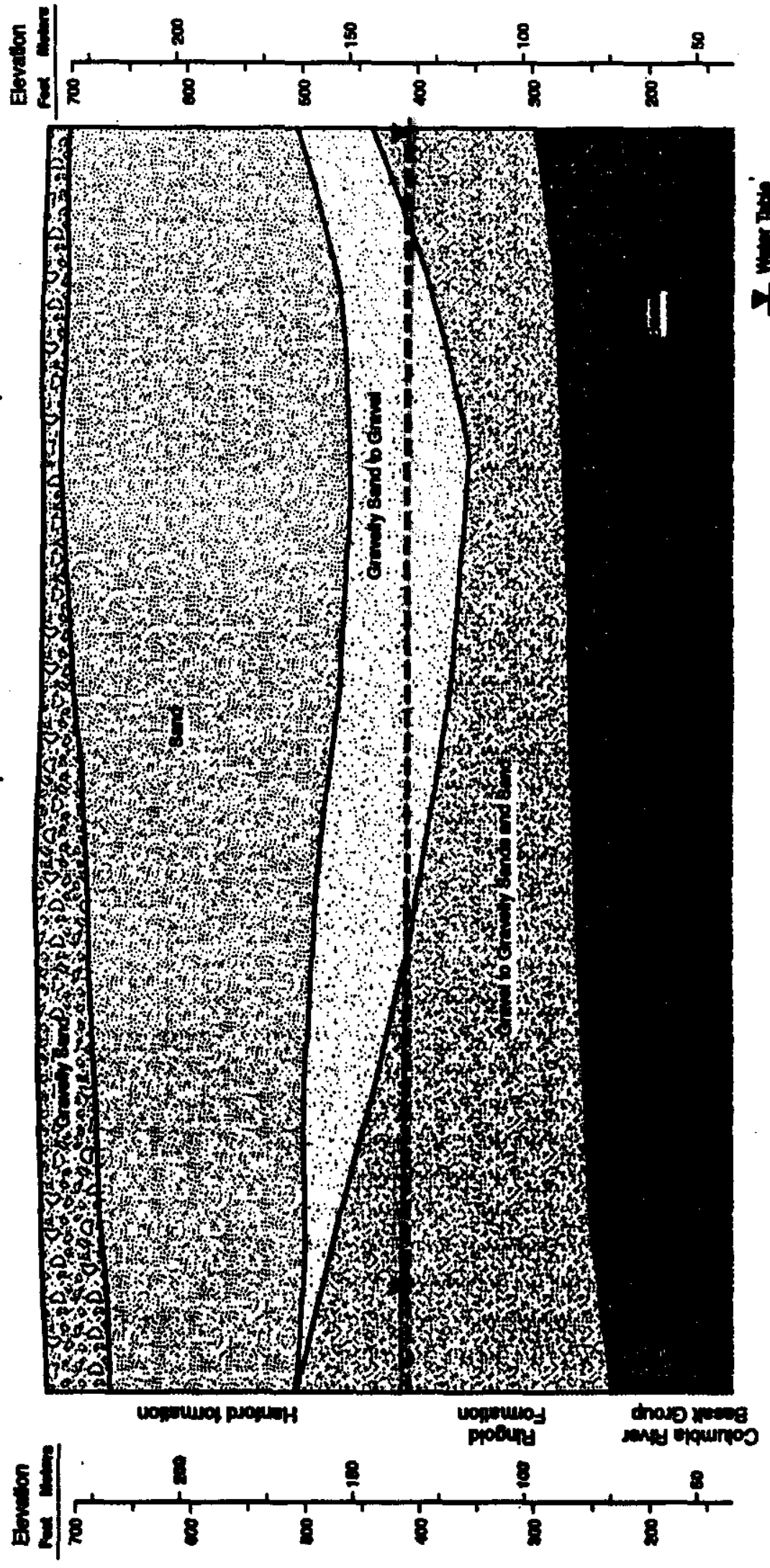


\section{DOE/ORP-2000-19, REV. 0 \\ Beference: DOE/ORP-2000-07, REV.0}

\subsection{Near-Field Hydrology Data}

The processes and data important for moisture flow in the zone between the surface and the bottom of the engineered disposal facility are described in Near-Field Hydrology Data Package for the Immobilized Low-Activity Waste 2001 Performance Assessment (Meyer 1999), which is also attached as Appendix $\mathrm{L}$ in Mann/Puigh (2000). Physical and hydraulic properties (particle size distribution, particle density, bulk density, porosity, water retention, and hydraulic conductivity as a function of moisture content) and associated transport parameters (dispersivity and effective diffusion coefficient) are given for the surface cover materials, the vault structure, diversion layers, the water conditioning layer, and the backfill materials. Table 3.2 presents bestestimate parameter values for near-field materials. Best estimate values for transport parameters can be found in Meyer (1999 - Chapter 5).

Table 3.2 Best-Estimate Hydraulic Parameter Values For Near-Field Materials

\begin{tabular}{|c|c|c|c|c|c|c|c|}
\hline Material & $\begin{array}{l}P_{p} \\
\left(g / \mathrm{cm}^{3}\right)\end{array}$ & $\begin{array}{l}p_{b} \\
\left(g / \mathrm{cm}^{3}\right)\end{array}$ & $\theta$ & $\theta_{r}$ & $\alpha\left(\mathrm{cm}^{-1}\right)$ & $n$ & $\mathrm{~K}_{\star}(\mathrm{cm} / \mathrm{s})$ \\
\hline \multicolumn{8}{|l|}{ Surface Barrier } \\
\hline $\begin{array}{l}\text { Silt Loam-Gravel } \\
\text { admixture }\end{array}$ & 2.72 & 1.48 & $\overline{0.456}$ & 0.0045 & 0.0163 & 1.37 & $8.4 \times 10^{-5}$ \\
\hline Compacted Silt Loam & 2.72 & 1.76 & 0.353 & 0.0035 & 0.0121 & 1.37 & $1.8 \times 10^{-6}$ \\
\hline Sand Filter & 2.755 & 1.88 & 0.318 & 0.030 & 0.538 & 1.68 & $8.58 \times 10^{-3}$ \\
\hline Gravel Filter & 2.725 & 1.935 & 0.290 & 0.026 & 8.1 & 1.78 & $1.39 \times 10^{-2}$ \\
\hline Gravel Drainage & 2.725 & 1.935 & 0.290 & 0.006 & 17.8 & 4.84 & 2.0 \\
\hline Asphaltic Concrete & 2.63 & 2.52 & 0.04 & 0.000 & $1.0 \times 10^{-7}$ & 2.0 & $1 \times 10^{-21}$ \\
\hline \multicolumn{8}{|l|}{ Capillary Break } \\
\hline Diversion Layer Sand & 2.8 & 1.65 & 0.371 & 0.045 & 0.0683 & 2.08 & $3.00 \times 10^{-2}$ \\
\hline Diversion Layer Gravel & 2.8 & 1.38 & 0.518 & 0.014 & 3.54 & 2.66 & 1.85 \\
\hline \multicolumn{8}{|l|}{ Trench/Vault } \\
\hline Filler Material & 2.63 & 1.59 & 0.397 & 0.005 & 0.106 & 4.26 & $3.79 \times 10^{-2}$ \\
\hline Glass Waste & 2.68 & 2.63 & 0.02 & 0.00 & 0.2 & 3 & 0.01 \\
\hline Vault Concrete & 2.63 & 2.46 & 0.067 & 0.00 & $3.87 \times 10^{-5}$ & $\longdiv { 1 . 2 9 }$ & $1.33 \times 10^{-9}$ \\
\hline Backfill & 2.76 & 1.89 & 0.316 & 0.049 & 0.035 & 1.72 & $1.91 \times 10^{-3}$ \\
\hline $\mathbf{K}_{\mathbf{s}}=$ saturate & $p$ & 5 & ensity & $\begin{array}{l}\theta_{\mathrm{s}}= \\
\alpha, n\end{array}$ & 5 & ontent & \\
\hline
\end{tabular}

\subsection{Far-Field Hydrology}

The processes and data important for moisture flow in the zone between the bottom of the engineered disposal facility and the water table are described in Far-Field Hydrology Data Package for the Immobilized Low-Activity Waste Performance Assessment (Khaloel 1999), which is also attached as Appendix M in Mane/Puigh (2000). This document summarizes the hydraulic parameter estimates based on data from the IIAW borehole and data on gravelly samples from the 100 Area boreholes. The document also describes the processes for upscaling 


\section{DOE/ORP-2000-19, REV. 0 \\ Beffence: DOE/ORP-2000-07, REV. 0}

such small-scale laboratory measurements to field-scale applications, and provides recommendations for parameters to be used at that scale. Table 3.3 provides the best estimate values impacting moisture flow. Best estimate values for transport parameters associated with the base case effective transport parameters (bulk density, diffusivity, and dispersivity) are also described in Khaleel (1999).

Table 3.3 Best-Estimate Hydraulic Parameter Values For Far-Field Layers

\begin{tabular}{|l|l|l|l|l|l|l|}
\hline Formation & $\theta_{\mathrm{l}}$ & $\theta_{\mathrm{r}}$ & $\begin{array}{l}\alpha \\
(1 / \mathrm{cm})\end{array}$ & $\mathrm{n}$ & $\ell$ & $\begin{array}{l}\mathrm{K}_{\mathbf{c}} \\
(\mathrm{cm} / \mathrm{s})\end{array}$ \\
\hline Sandy & 0.375 & 0.041 & 0.057 & 1.768 & 0.5 & $2.88 \times 10^{-3}$ \\
\hline Gravelly & 0.138 & 0.010 & 0.021 & 1.374 & 0.5 & $5.60 \times 10^{-4}$ \\
\hline
\end{tabular}

$\theta_{\mathrm{s}}=$ saturated water content $\theta_{\mathrm{r}}=$ residual water content $\alpha, \mathrm{n}=$ van Genutchen fitting parameters $\ell=$ pore size distribution factor $\mathrm{K}_{\mathbf{s}}=$ saturated hydraulic conductivity

Overall, compared to the sandy sequence, the gravelly sequence is characterized by a much smaller saturated water content, higher bulk density, higher log-conductivity variance, smaller log-unsaturated conductivity variance, a much smaller macroscopic anisotropy and smaller dispersivities (Khaleel 1999). An anisotropy ratio (ratio of horizontal to vertical hydraulic conductivity) in excess of one results in an enhanced lateral migration. For purposes of restricting lateral migration (i.e., a conservative assumption), an isotropic model was used for both strata.

Longitudinal dispersivities of $200 \mathrm{~cm}$ and $30 \mathrm{~cm}$ are used for the sandy and gravelly sequences, respectively (Khaleel 1999). Lateral dispersivities are estimated to be $1 / 10^{\text {t }}$ of the longitudinal estimates. The effective, large-scale diffusion coefficients for both sandy and gravel-dominated sequences are assumed to be a function of volumetric moisture content, $\theta$. VAM3DF uses the Millington-Quirk (1961) empirical relation:

$D_{c}(\theta)=D_{0} \frac{\theta^{10 / 3}}{\theta_{0}^{2}}$

where $D_{0}(\theta)$ is the effective diffusion coefficient of an ionic species, and $D_{0}$ is the effective diffusion coefficient for the same species in free water. The molecular diffusion coefficient for all species in pore water is assumed to be $2.5 \times 10^{-5} \mathrm{~cm}^{2} / \mathrm{s}$ (Kincaid 1995).

\subsubsection{Geochemical Retardation Factors}

Chemical interactions with facility, near-field materials, and the soil in the vadose zone can greatly slow the transport of contaminants. Geochemical effects are based on the discussion and values presented in Geochemical Data Pactage for the Hanford Immobitized Low-Activity Tank Waste Performance Assessment (Kaplan 1999), and also provided in appendix $\mathrm{N}$ of Mann/Puigh (2000). The amount of slowing is described by a multiplicative factor known as the geochemical retardation factor. Geochemical retardation factors for these analyses are based on extensive laboratory work performed at the Hanford Site. 


\section{DOE/ORP-2000-19, REV. 0 Beference: DOE/ORP-2000-07, REV. 0}

Geochemical retardation in unsaturated conditions is predicted to be

$R_{f}=1+\rho K_{d} / \theta$

where $\quad \mathbf{R}_{f}$ is the geochemical retardation factor (dimensionless)

$\rho \quad$ is the bulk density of the material $\left(\mathrm{g} / \mathrm{cm}^{3}\right)$

$\mathbf{K}_{d}$ is the chemical distribution coefficient (liter/g)

$\theta \quad$ is the volumetric moisture content (dimensionless).

A derivation of the general contaminant transport equation is given in the 1998 ILAW PA report (Mann, 1998 - Appendix D, Section D.2.3). The chemical distribution coefficient $\left(\mathrm{K}_{d}\right)$ is measured in the laboratory by comparing the amount of material trapped in or on the soil matrix to the amount in the water phase.

Tables 3.4 and 3.5 provide estimates for $K_{\phi}$ from recent measurements and for the $K_{d s}$ used in the analyses provided in this report. Unloss otherwise stated the $\mathrm{K}_{\mathrm{s}}$ are provided for the chemically impacted far field sandy sequence beseath the disposal facility (Table 3.4) and the near field materials (Table 3.5). The "Probable $\mathrm{K}_{\mathrm{d}}$ " is the best estimate for the $\mathrm{K}_{\mathrm{d}}$. Finally, the " $K_{d}$ value used' refers to the value of $K_{d}$ used in the analyses provided in this report. This $\mathbf{K}_{d}$ value was conservatively chosen to be one of six values ( 0 [corresponding to $\mathrm{Tc}$ ], 0.6 [corresponding to U], 4.0 [corresponding to Se], 10 [corresponding to Sr], 80 [corresponding to $\mathrm{Sn}$ and $\mathrm{C}$ ], and 150 [corresponding to Pu]) that are less than or equal to the probable $\mathrm{K}_{\mathbf{d}}$ value provided in these tables. The elements selected were shown to be the most important in the 1998 IIAW PA. The values in parentheses provided it Table 3.4 are for the unperturbed (near neutral $\mathrm{pH}$, ionic strengths between $\sim 0$ and 0.01 , and only trace contaminant concentrations) far field sand sequence.

For convenience in modeling, a subset of $\mathrm{K}_{d}$ values was used in these analyses. The computer code VAMBDF (See section 3.5.3) treats the chemical distribution coefficients as point-estimate values, not as probability functions. Therefore, the actual $K_{d}$ values used were reduced to one of eight value sets for the near and far fields (see Tables 3.4 and 3.5).

Because radiomuclides spend significantly less time in the unconfined aquifer than in the vadose zone, no credit for increased travel time in the unconfined aquifer because of geochemical retardation was taken.

The geochemistry is described using two parameters, the distribution coefficient $\left(\mathbf{K}_{\mathbf{d}}\right.$ value) and the colubility product of a specified solid. The distribution coefficient is a thermodynamic construct. It is the ratio of the concentration of a species reversibly adsorbed/exchanged to a geomedia's surface site divided by the concentration of the species in solution. Parameters are given for four zones:

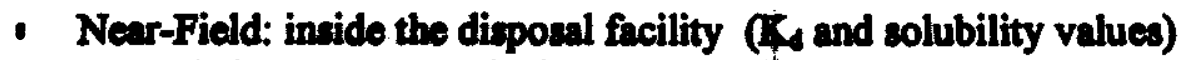

- Degraded Concrete Vault ( $K_{d}$ and solubility values)

- Chemically Impacted Far-Field in Sand Sequence (R, values only)

- Chemically Impacted Far-Field in Gravely Sequence ( $\mathbf{K}_{d}$ values only)

- Far Field in Gravel Sequence [unconfined aquifer] ( $\boldsymbol{K}_{d}$ values only). 


\section{DOE/ORP-2000-19, REV. 0 \\ Refecens: DOE/ORP-2000-07, REV. 0}

Values are based on site-specific samples for the most part, but in a few cases depend on literature values or chemical similarity. Table 3.4 provides the best estimate $\mathrm{K}_{\mathrm{d}}$ values for the chemically impacted far-field sand sequence. The gravel corrected the best estimate $\mathrm{K}_{\mathbf{d}}$ values for the chemically impacted far-field gravel sequence are a factor of 10 smaller than the values given in Table 3.4. The values in parentheses in the table are for the unperturbed far-field sand sequence. The aqueous phase is assumed to be untainted Hanford groundwater except for trace levels of radionuclide and the solid phase is assumed to be natural Hanford sand-dominated sequence sediment. The literature values upon which the values were based had an aqueous phase near neutral pH, ionic strength between $\sim 0$ to 0.01 , and trace radionuclide concentrations.

Other important geochemical data (e.g., near-field field values for important radionuclides) are displayed in Table 3.5. For the analyses in the white paper the $K_{d}$ 's for the unconfined aquifer were set equal to zero.

Table 3.4 Best-Estimate $K_{d}$ Values For The Far-Field Sand Sequence ${ }^{(\bullet)}$

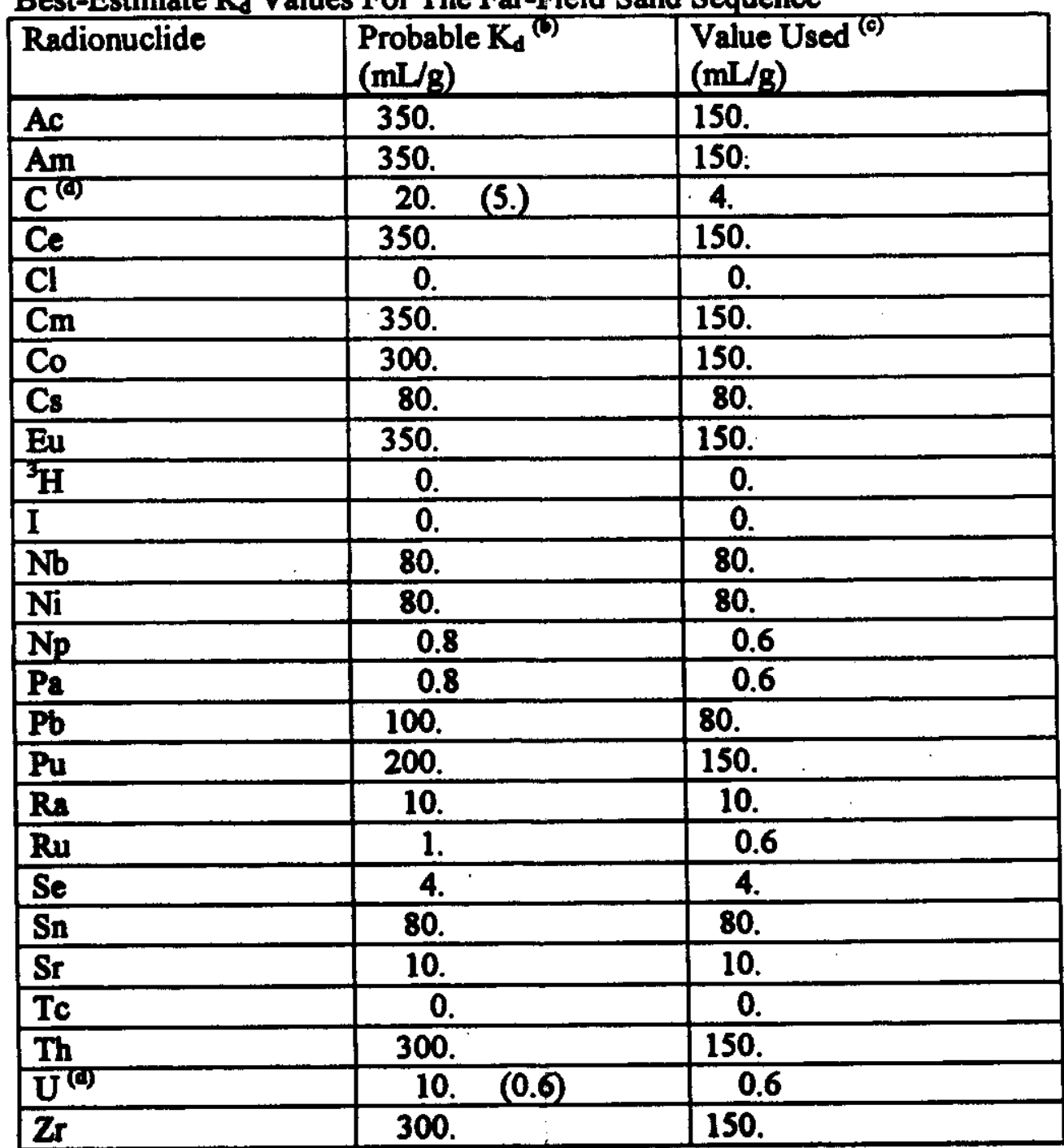

(a) The main values in the table are for the chemically impacted far-field sand sequence. The aqueous phase is moderately altered from the cement and glass leachate emanating from the near field; $\mathrm{pH}$ is between 8 (background) and 11, and the ionic strength is 


\section{DOE/ORP-2000-19, REV. 0 \\ Reference: DOE/ORP-2000-07, REV. 0}

between 0.01 (background) and 0.1 . The solid phase is in the sand-dominated sequence and is slightly altered due to contact with the caustic aqueous phase.

(b) Probable $K_{d}$ is the best estimate for $K_{d}$

(a) Value Used is the $K_{d}$ value used in the analyses provided in this report

(d) The values in parentheses in the table are for the unperturbed far-field sand sequence.

The aqueous phase is assumed to be untainted Hanford groundwater except for trace levels of radionuclide and the solid phase is assumed to be natural Hanford sanddominated sequence sediment. The literature values upon which the values were based had an aqueous phase near neutral $\mathrm{pH}$, ionic strength between $\sim 0$ to 0.01 , and trace radionuclide concentrations.

Table 3.5 provides the geochemical values for other regions. Note that the $K_{d}$ values in concrete used for $U$, and $I$ have been set equal to zero which is conservative.

Table 3.5 Other Important Geochemical Values $\left({ }^{(}\right)$

\begin{tabular}{|c|c|c|c|}
\hline Element & $\begin{array}{l}\text { Probable } \\
\text { Value }{ }^{(b)}\end{array}$ & $\begin{array}{l}\text { Value } \\
\text { Used }{ }^{(c)}\end{array}$ & Zone and Geochemical Value \\
\hline Tc & 1 & $\mathbf{0}$ & Zone 1: Near-Field $\mathrm{K}_{\mathrm{d}}(\mathrm{mu} / \mathrm{g})$ \\
\hline$\overline{\mathbf{U}}$ & 20 & 0.6 & Zone 1: Near-Field $\mathrm{K}_{1}(\mathrm{~mL} / \mathrm{g})$ \\
\hline $\bar{U}$ & $1 \times 10^{-1}$ & $1 \times 10^{-7}$ & Zone 1: Near Field Solubility (M) \\
\hline I & 2 & 0 & Zorte 2: Degraded Aged Concrete $\mathrm{K}_{4}(\mathrm{~mL} / \mathrm{g})$ \\
\hline $\mathbf{U}$ & 100 & $\mathbf{0}$ & Zone 2: Degraded Aged Concrete $\mathrm{K}_{d}(\mathrm{~mL} / \mathrm{g})$ \\
\hline $\bar{U}$ & $1 \times 10^{-7}$ & $1 \times 10^{-7}$ & $\begin{array}{l}\text { Zone 2: Degraded Aged Concrete Solubility } \\
\text { (M) }\end{array}$ \\
\hline
\end{tabular}

(a) The main values in the table are for the chemically impacted far-field sand sequence. The aqueous phase is moderately altere from the cement and glass leachate emanating from the near field; pH is between 8 (bickground) and 11, and the ionic strength is between 0.01 (background) and 0.1 . The solid phase is in the sand-dominated sequence and is slightly altered due to contact with the caustic aqueous phase.

(b) Probable $K_{d}$ is the best estimate for $K_{d}$

(c) Value Used is the $K_{ه}$ value used in the analyses provided in this report

\subsubsection{Unconfined Aquifer Properties and Boundaries}

The base-case groundwater flow and contaminant transport of contaminants from the Immobilized Low Activity Waste (ILAW) facility was calculated with the current version of the Hanford Site-wide groundwater model. This three-dimensional model, currently being used by the Hanford Groundwater Project and recommended as the proposed site-wide groundwater model in Hanford Site groundwater model consolidation process, is based on the Coupled Fluid, Energy, and Solute Transport (CFEST-96) Code (Gupta, 1987). The specific implementation of this model is more fully described in Wurstnet et al (1995) and Cole et al. (1997). This specific model was most recently used in the Hanford Site Composite Analysis (Cole at al. 1997; Kincaid et al. 1998), which is a companion analysis to the existing preliminary performance assessment analyses of the ILAW disposal (Mann et al. 1998) and the solid waste burial grounds in the 200East and 200-West areas (Wood et al. 1996, 1995). The Composite Analysis is also a companion 


\section{DOE/ORP-2000-19, REV. 0 \\ Reference: DOE/ORP-2000-07, REV. 0}

document to the Remedial Investigation/Feasibility Study (RI/FS) (DOE 1994) done to support the Environmental Restoration Disposal Facility.

\subsection{Hydrogeologic Framework}

The conceptual model of groundwater flow is based on nine major hydrogeologic units in the left hand column shown in Figure 3.3. The basis for the identification of these major hydrogeologic units in the aquifer system is more fully described in Thorne et al $(1992,1993$, and 1994). Although nine hydrogeologic units were defined, only seven are found below the water table during post-Hanford conditions. Odd-numbered Ringold model units $(5,7$, and 9$)$ are predominantly coarse-grained sediments. Even-numbered Ringold model units $(4,6$, and 8$)$ are predominantly fine-grained sediments with low permeability. The Hanford formation combined with the pre-Missoula gravel deposits were designated model unit 1. Model units 2 and 3 correspond to the early Palouse soil and Plio-Pleistocene deposits, respectively. These units lie above the current water table. The predominantly mud facies of upper Ringold unit identified by Lindsey et al (1995) was designated model unit 4. However, a difference in the definition of model units is that the lower, predominantly sand, portion of the upper Ringold unit described in Lindsey et al. (1995) was grouped with model unit S, which also includes Ringold gravel/sand units $\mathbf{E}$ and $\mathrm{C}$. This was done because the predominantly sand portion of the upper Ringold is expected to have hydraulic properties similar to units $\mathrm{E}$ and $\mathrm{C}$. The lower mud unit identified by Lindsey et al (1995) was designated units 6 and 8. Where they exint, the gravel and sand units B and D, which are found within the lower Ringold, were designated model unit 7. Gravels of Ringold unit A were designated unit 9 for the model, and the underlying basalt was designated model unit 10. However, the basalt was assigned a very low hydraulic conductivity and was essentially impermeable in the model.

The lateral extent and thickness distribution of each hydrogeologic unit were defined based on information from well driller's logs, geophysical logs, and an understanding of the geologic environment. These interpreted areal distributions and thicknesses were then integrated into EarthVision (Dynamic Graphics, Inc., Alaneda, California), a three-dimensional, visualization, software package that was used to construct a database of the three-dimensional hydrogeologic framework.

\subsection{Recharge and Aquifer Boundaries}

Both natural and artificial recharge to the aquifer were incorporated in the model. Natural recharge to the unconfined aquifer system occurs from infiltration of 1) runoff from elevated regions along the western boundary of the Hanford Site; 2) spring discharges originating from the basalt-confined aquifer system, also along the weatern boundary; and 3) precipitation falling across the site. Some recharge also occurs along the Yakima River in the southern portion of the site. Natural recharge from runoff and irrigation in the Cold Creek and Dry Creek Valleys, up-gradient of the site, also provides a source of groundwater inflow. Areal recharge from precipitation on the site is highly variable, both spatially and temporally, and depends on local climate, soil type, and vegetation. A recharge distribution based on Fayer and Walters (1995) for 1979 was applied in the model. 


\section{DOE/ORP-2000-19, REV. 0 \\ Beference: DOE/ORP-2000-07, REV. 0}

The other source of recharge to the unconfined aquifer is wastewater disposal. Large volume of artificial recharge from wastewater discharged to disposal facilities on the Hanford Site over the past 50 years has significantly impacted groundwater flow and contaminant transport in the unconfined aquifer system. However, the volume of artificial recharge will decrease significantly in the near future and the water table is expected to return to more natural conditions after site closure.

The flow system is bounded by the Columbia River on the north and east and by the Yakima River and basalt ridges on the south and west. The Columbia River represents a point of regional discharge for the unconfined aquifer system. The amount of groundwater discharging to the river is a function of local hydraulic gradient between the groundwater elevation adjacent to the river and the river-stage elevation. This hydraulic gradient is highly variable because the river stage is affected by releases from upstream dams. To approximate the long-term effect of the Columbia River on the unconfined aquifer system in the three-dimensional model, the Columbia River was represented as a constant-head boundary over the entire thickness of the aquifer. The CHARIMA river-simulation model (Walters et al. 1994) was used to generate longterm, average, river-stage elevations for the Columbia River based on 1979 conditions. The Columbia River boundary to the middle of the river channel to reflect more accurately the hydraulic interaction of the unconfined aquifer and the river. The Yakima River was also represented as a specified-head boundary over the entire thickness of the aquifer.

At Cold Creek and Dry Creek Valleys, the unconfined aquifer system extends westward beyond the boundary of the model. To approximate the groundwater flux entering the modeled area from these valleys, both constant-head and constant-flux boundary conditions were defined. A constant-head boundary condition was specified for Cold Creek Valley for the steady-state model calibration runs. Once calibrated, the stendy-state model was used to calculate the flux condition that was then used in the post-Hanford steady state flow simulation. The constant-flux boundary was used because it better represents the response of the boundary to a declining water table than a constant-head boundary. Discharges from Dry Creek Valley in the model area, resulting from infiltration of precipitation and spring discharges, are approximated with a prescribed-flux boundary condition.

The basalt underlying the unconfined aquifer sediments represents a lower boundary to the unconfined aquifer system. The potential for interflow (recharge and discharge) between the basalt-confined aquifer system and the unconfiped aquifer system is postulated to be small relative to the other flow components extimated for the unconfined aquifer system. Therefore, interflow with underlying basalt units was not included in the current three-dimensional model. The basalt was defined in the model as an essentially impermeable unit underlying the sediments.

\subsection{Flow and Transport Properties}

To model groundwater flow, the distribution of hydraulic properties, including both horizontal and vertical hydraulic conductivity and porosity were needed for each hydrogeologic unit defined in the model. In addition, to simulate movement of contaminant plumes, transport properties were needed, including contaminam-specific distribution coefficients, bulk density, effective porosity, and longitudinal and transverse dispersivities. 
Figure 3.3 Comparison of Generalized Geology and Hydrostratigraphic Columns

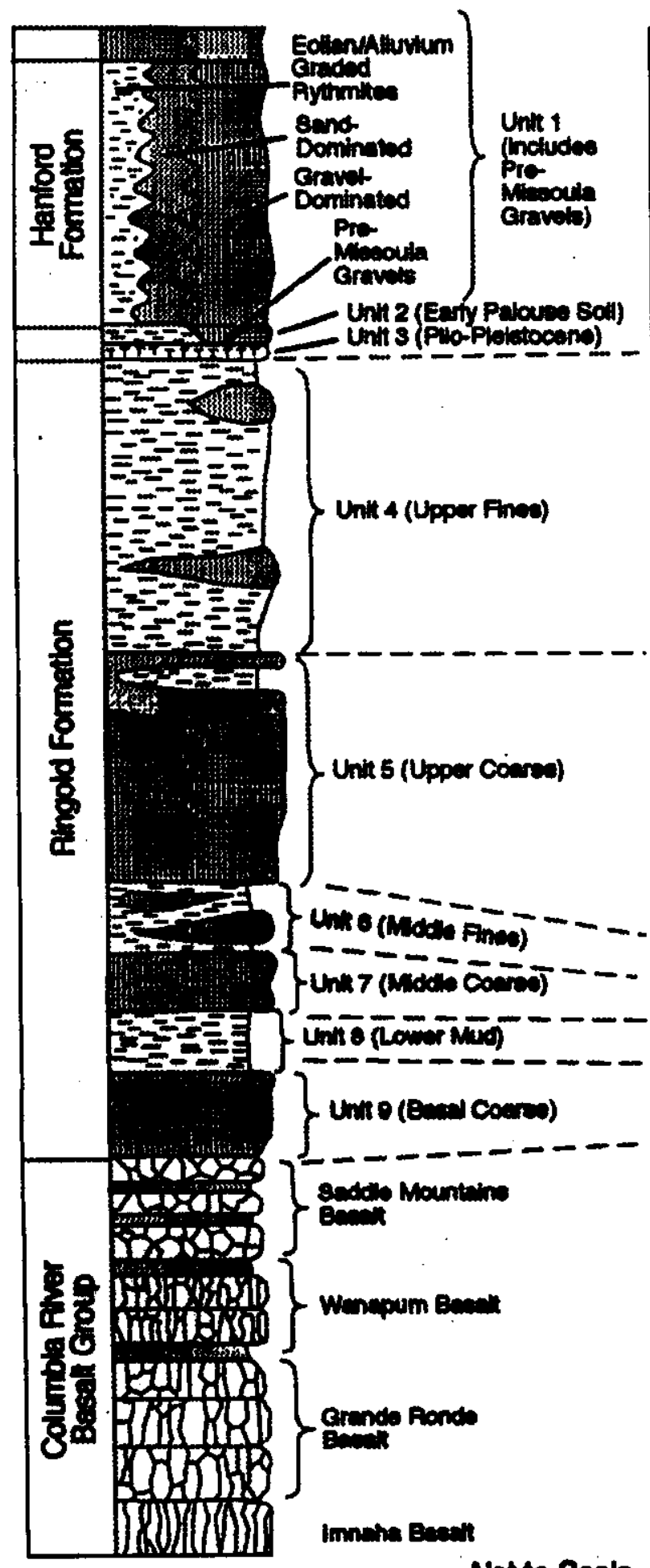

From PNL-6971

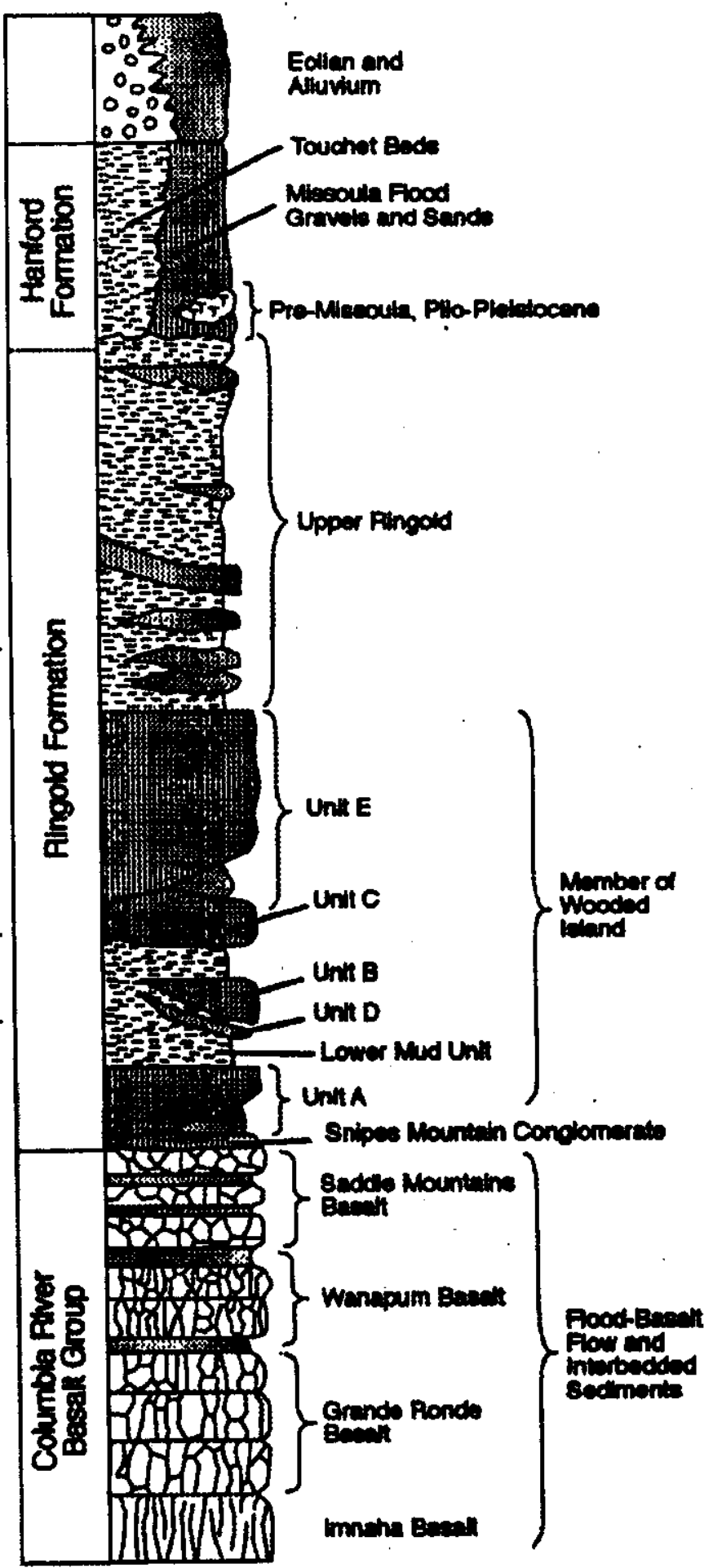

After BHIF00184 


\section{DOE/ORP-2000-19, REV. 0 \\ Reference: DOE/ORP-2000-07, REV. 0}

In the original model calibration procedure described in Wurstner et al. (1995), measured values of aquifer transmissivity were used in a two-dimensional model with an inverse modelcalibration procedure to determine the transmissivity distribution. Hydraulic head conditions for 1979 were used in the inverse calibration because measured hydraulic heads were relatively stable at that time. Details concerning the updated calibration of the two-dimensional model are provided in Cole et al (1997).

Figure 3.4 Hydraulic Conductivity Distribution Obtained for the Uppermost Unconfined Aquifer from Inverse Calibration for 1979 Conditions

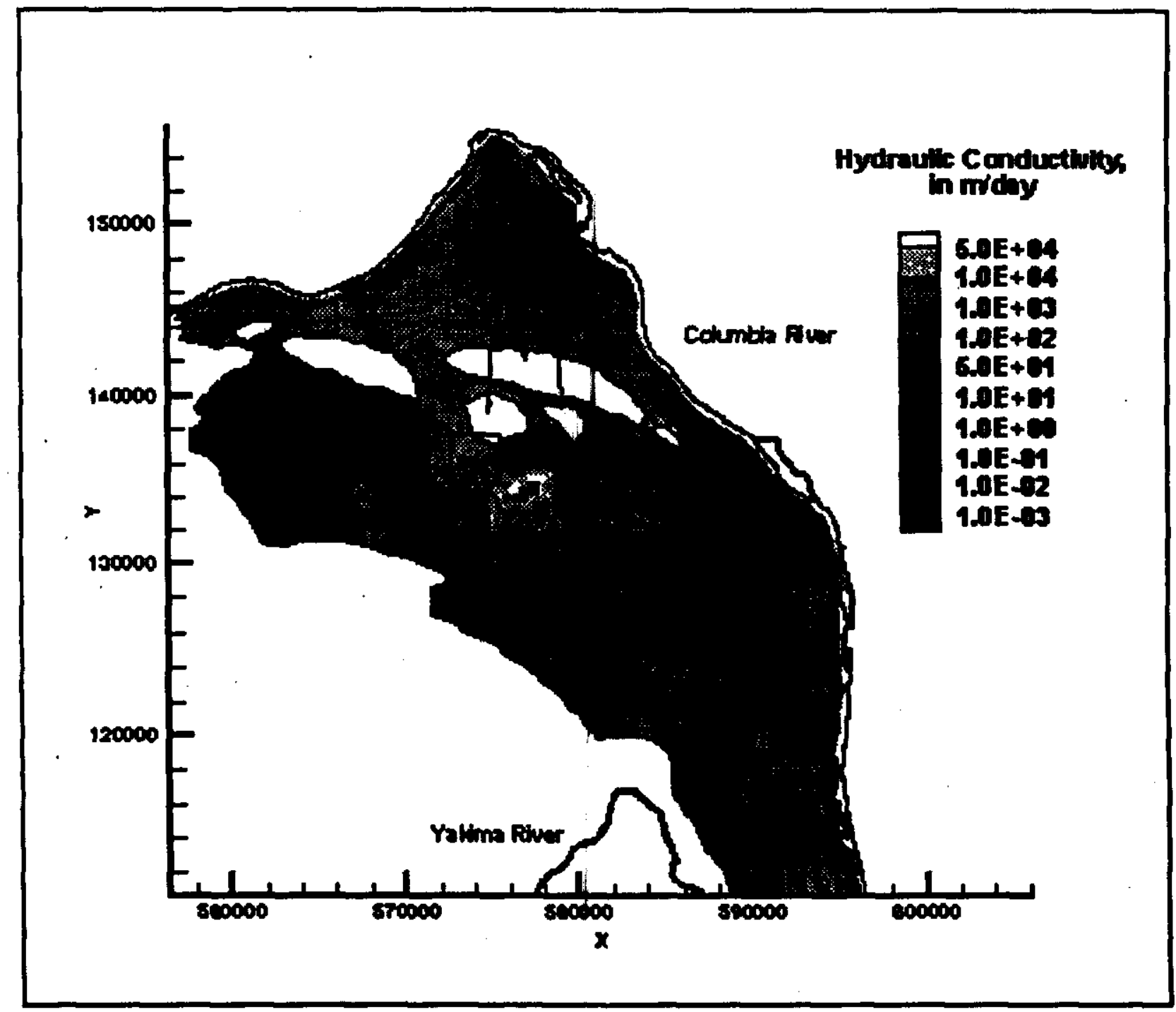

Hydraulic conductivities were assigned to the three-dimensional model units 80 that the total aquifer transmisaivity from inverse calibration was preserved at every location. The vertical distribution of hydraulic conductivity at each spatial location was determined based on the transmissivity value and other information, including facies descriptions and hydraulic property values measured for similar facies. A complete description of the seven-step process used to vertically distribute the transmissivity among the model hydrogeologic units is described in Cole 


\section{DOE/ORP-2000-19, REV. 0 \\ Reference: DOE/ORP-2000-07, REV. 0}

et al (1997). The hydraulic conductivity distribution resulting from this redistribution of aquifer transmissivity in the upper part of the aquifer is provided in Figure 3.4.

Information on transport properties used in past modeling studies at the Hanford Site is provided in Wurstner et al. (1995). Estimates of model parameters were developed to account for contaminant transport and dispersion in all transport simulations. Specific model parameters estimated included longitudinal and transverse dispersivity $\left(D_{1}\right.$ and $\left.D_{t}\right)$ and aquifer porosity.. This section briefly summarizes estimated transport properties.

For the regional scale analysis, a longitudinal dispersivity of $95 \mathrm{~m}$ was selected to be within the range of recommended grid Peclet numbers $\left(P_{0}<4\right)$ for acceptable solutions. The 95 $m$ estimate is about one-quarter of the grid spacing in the finest part of the model grid in the 200Area plateau where the smallest grid spacing is on the order of about $375 \mathrm{~m}$ by $375 \mathrm{~m}$. The effective transverse dispersivity was assumed to be 10 percent of the longitudinal dispersivity. Therefore, $9.5 \mathrm{~m}$ was used in all simulations.

The effective porosity was estimated from limited measurement of porosity and specific yields obtained from multiple-well aquifer tests. These values range from 0.01 to 0.37 . Laboratory measurements of porosity, which range from 0.19 to 0.41 , were available for samples from a few Hanford Site wells and were also considered. The few tracer tests conducted indicate effective porosities ranging from 0.1 to 0.25 . Based on the ranges of values considered, a best estimate of an effective porosity value for all simulations was assumed to be 0.25 .

\subsubsection{Waste Package}

\subsubsection{Waste Package Geometry}

The DOE has entered into a contract with BNFL, Inc. to design and ultimately process approximately $10 \%$ of the waste from the Hanford tanks in an initial phase (Phase 1). (The contract identifies a minimum of 6,000 packages [having the dimensions of $1.4 \mathrm{~m}$ cubed] and Kirkbride (1999) estimates that approximately 70,000 ILAW packages will be generated for all the IIAW in Phase 1 and Phase 2). The product description and specifications defined in this section are based on the current DOE contract (DOE/BNFL 1998) and the BNFL, Inc. reports submitted to the DOE as part of the contract negotiations. The definition of the product form and specification for the remaining $91 \%$ of the Hanford tank waste is not defined at this time. For the purposes of this assessment activity, all the HAW waste products are assumed equivalent to the BNFL, Inc. descriptions and DOE specifications for the Phase 1 contract.

The ILAW product to be provided by BNFL, Inc. consists of a silicate glass monolith sealed in a stainless steel (304L) package. The headspace above the silicate glass in the package is filled with silicate sand (BNFL 1998). The steel package has external dimensions of $1.4 \mathrm{~m} \mathrm{x}$ $1.4 \mathrm{~m} \times 1.4 \mathrm{~m}(-0 \mathrm{~m} /+0.05 \mathrm{~m}$ tolerances $)$. On-gbing discussions may change these package dimensions, but such changes are not expected to materially affect any conclusion in this report. The stainless steel wall thickness of the package is $6 \mathrm{~mm}$. The package top is $12 \mathrm{~mm}$ plate and the bottom is $8 \mathrm{~mm}$ plate. BNFL, Inc. plans to load each ILAW package to within $85 \%$ capacity (by volume) and fill the void space with silicate sand such that the remaining free fill space is less than $5 \%$ (by volume). (BNFL, Inc. is also considering an alternative inert filling material 


\section{DOE/ORP-2000-19, REV. 0 \\ Referenc: DOE/ORP-2000-07, REV. 0}

that may be introduced in liquid form, such as grout.) The top lid will be welded using the tungsten-inert gas (TIG) process.

Modification 12 of the BNFL contract (see DOE/BNFL 1998) was issued on January 24, 2000 and required IIAW canisters in the form of right circular cylinders (1.22 m diameter by $2.29 \mathrm{~m}$ tall. This occurred after the data packages used in these analyses was issued and will not be explicitly addressed in this report. Future work will use the latest dimensions for the waste package and other facility information.

For the waste form calculations discussed in section 3.5.3 the glass waste material was assumed to be fractured. Also, the surface area was assumed to be 10 times greater than that of an unfractured $1.4 \mathrm{~m}$ cube (no credit was taken for the reduction in surface area. Hence,

$A_{\text {stom }}^{s}=\frac{A_{\text {drem }}}{V_{\text {stam }}}=\frac{6(1.4)^{2}}{(1.4)^{3}} \times 10=42.8 \mathrm{~m}^{2} \mathrm{~m}^{-3}$

where $A_{s-m}^{s}$ is the specific surface area of the glass, $A_{d-2}$ is the surface area of the glass, and $V_{\text {slaws }}$ is the volume of the glass.

The surface area of the steel waste package was determined by assuming that both the inner and outer surfaces of the steel container were available to react.

$$
A_{\text {mat }}^{s}=\frac{A_{\text {and }}}{V_{\text {mat }}}=\frac{12(1.4)^{2}}{[0.012+0.008+4(0.006)](1.4)^{2}}=272.73 \mathrm{~m}^{2} \mathrm{~m}^{3}
$$

where $A_{\text {seal }}^{\delta}$ is the specific surface area of the steel container, $A_{\text {mad }}$ is the surface area of the steel container, and $V_{\mathrm{s}}$ is the volume of the steel container.

\subsubsection{Waste Form Release Rate}

The 1998 ILAW PA showed that the release rate from the waste form was one of the key. parameters in the performance assessment. This rate is a major determinant of the impact of disposal as well as setting the temporal structure of that impact. The data for determining the waste form release rate are given in Waste Form Release Data Package for the 2001 Immobilized Low-Activity Waste Performance Assessment (McGrail 1999) and appendix K of Mann/Puigh 2000.

Dissolution of the glass waste form is the required first step to release a specific radionuclide. Because glass dissolution rate depends on a variety of parameters (amoumt of moisture, amount of silicic acid [the main by-product of dissolved glass] in solution, $\mathrm{pH}$, amount and type of secondary phases) which will vary with time and location in the disposal system, the dissolution rate must be calculated. However, in order for the calculations to be technically defensible, they must be based on an accepted paradigm and an extensive database. 


\section{DOE/ORP-2000-19, REV. 0 \\ Reference: DOE/ORP-2000-07, REV. 0}

Over the last few decades, a general rate equation has been fashioned to described the dissolution of glass (and more ordered materials) into aqueous solution:

$$
k_{i}=\vec{k} v_{i} a_{\mathrm{H}^{+}}^{-\eta} e \frac{-E_{e}}{\mathrm{RT}}\left[1-\left(\frac{Q}{K}\right)^{0}\right] \prod_{j} a_{j}
$$

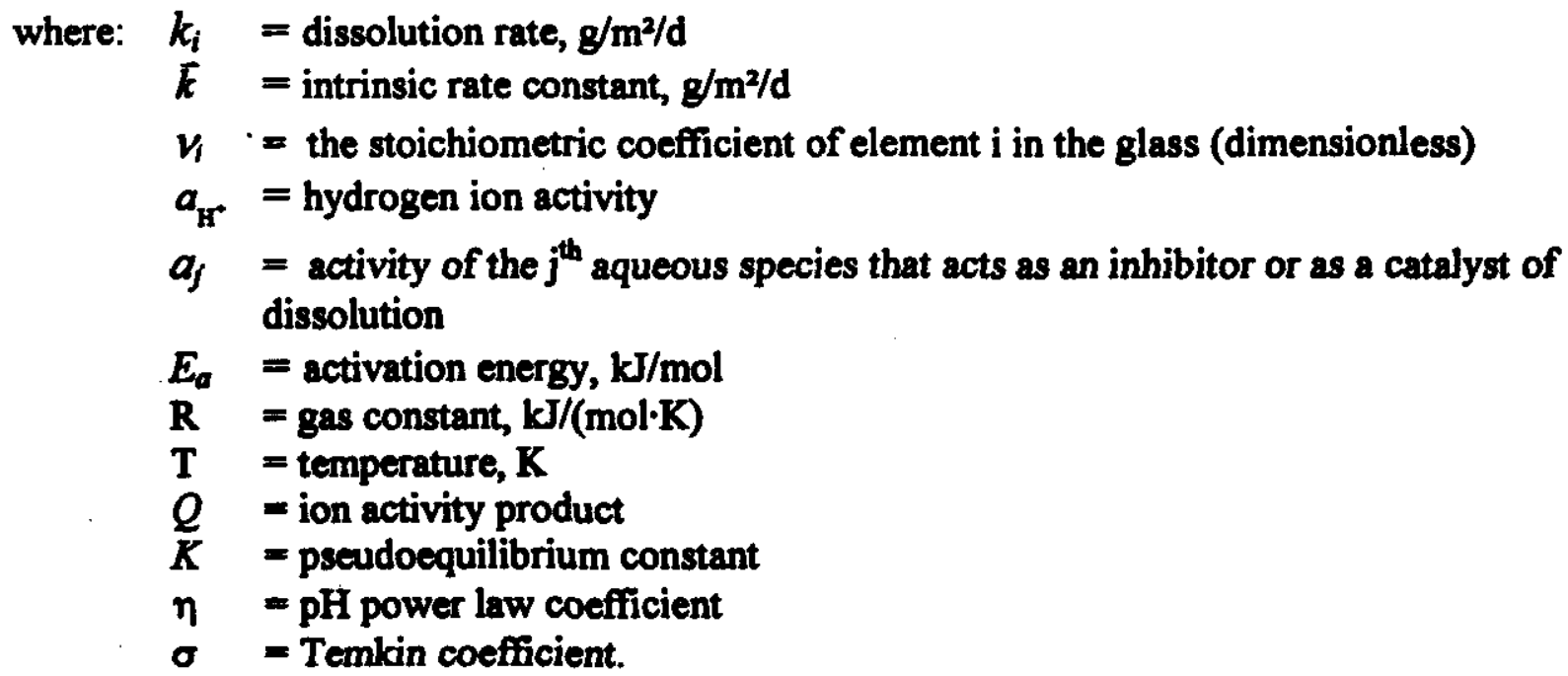

Equation (3.5) is an approximation for glass because glass is metastable, and the reaction proceeds one way (i.e. glass dissolves). Equation (3.5) also just describes the net chemical reaction of glass matrix dissolution. There are a number of secondary chemical reactions that also need to be considered. One important reaction is the exchange of alkali ions in the glass for $\mathrm{H}^{+}$in water (McGrail 2000). The waste form contains high concentrations of sodium (up to 25 weight percent). At the temperatures of interest the exchange of sodium in the glass with $\mathrm{H}^{+}$in the water is important because the reaction effectively increases the $\mathrm{pH}$ of the solution. Finally, dissolution/precipitation reactions are important because they can strip chemicals from the aqueous solution, affecting the glass corrosion rate or trapping important contaminants.

The parameters in these equations are established by a set of various experiments, performed at various temperatures and pHs:

- singlo-pass flow-through test

- product consistency test

- vapor hydration test

- pressurized unsaturated flow-through teat.

The exact glass composition that BNFL, Inc. will use for ILAW has not been determined. The ILAW PA activity has worked with BNFL, Inc. and the DOE Tank Focus Area (Vienna 2000) to invertigate a set of glasses in the BNFL, Inc. processing space. For the 2001 ILAW PA, the base analyeis case uses LAWABP1 as the reference glase. This glass has the most extensive database of any glass in its processing space. The composition of LAWABP1 is based on the composition of preliminary BNFL, Inc. glasses. BNFL, Inc. has indicated that the composition of LAWABP1 remains in their design space. The corrosion reaction for LAWABP1 glass used in the waste form release calculations is: 
DOE/ORP-2000-19, REV. 0

Reference: DOE/ORP-2000-07, REV. 0

$$
\begin{aligned}
\text { LAWABP1 }+4.4247 \times 10^{-1} \mathrm{H}^{+}+1.8906 \times 10^{-1} \mathrm{H}_{2} \mathrm{O} \rightarrow 1.3557 \times 10^{-1} \mathrm{AlO}_{2}^{-} \\
+1.8365 \times 10^{-1} \mathrm{~B}(\mathrm{OH})_{3}(\mathrm{aq})+1.1307 \times 10^{-2} \mathrm{Cl}+1.8189 \times 10^{-4} \mathrm{CrO}_{4}^{2} \\
+1.4551 \times 10^{-3} \mathrm{~F}+2.1640 \times 10^{-2} \mathrm{Fe}\left(\mathrm{OH}_{3}(\mathrm{aq})+3.2281 \times 10^{-2} \mathrm{~K}^{+}\right. \\
+8.4849 \times 10^{-3} \mathrm{La}^{3+}+1.7145 \times 10^{-2} \mathrm{Mg}^{2+}+4.4604 \times 10^{-1} \mathrm{Na}^{+} \\
+7.7905 \times 10^{-4} \mathrm{HPO}_{4}^{2-}+8.6325 \times 10^{-4} \mathrm{SO}_{4}^{2-}+4.8184 \times 10^{-1} \mathrm{SiO}_{2}(\mathrm{aq}) \\
\left.+6.5900 \times 10^{-7} \mathrm{TcO}_{4}^{-}+2.1539 \times 10^{-2} \mathrm{Ti}_{(\mathrm{OH}}\right)_{4}(\mathrm{aq}) \\
+2.2084 \times 10^{-2} \mathrm{Zn}^{2+}+2.9447 \times 10^{-2} \mathrm{Zr}(\mathrm{OH})_{4}(\mathrm{aq})
\end{aligned}
$$

The stoichiometric coefficient for $\mathrm{Tc}$ is based on the average package concentration from the Immobilized Low Activity Tank Waste Inventory Data Package (Wootan 1999).

Table 3.6 provides a summary of the best-estimate values for parameters important in calculating contaminant release from the LAWABP1 glass waste form. The waste form release calculations included all solid phases listed in Table 3.6, with the exception of Na-Zn-Ti-silicate, because the equilibrium constant is not known.

\subsubsection{Disposal Facility}

The RH trench and concrete vault concepts summarized in section 2.2 are used for the conceptual model calculations. The dimensions for the RH trench model are taken from Figure 2.4. The dimensions for the concrete vault model were taken from the description provided in section 2.2.2.

The key components of the disposal system are the surface barrier, the sand-gravel capillary break, the trench (or vault) and the filler material. The surface barrier is assumed to be a modified RCRA subtitle C cap as described in Puigh (1999 - Section 4.0). Note that the cap is shaped like an inverted " $v$ " and placed with its apex along the length dimension (north-south) and centered over each trench or vault. The sicpe of the cap is $2 \%$. The cap extends $9 \mathrm{~m}$ beyond the inside edge of the RH trench (see Figure 2. )). (The surface cap extends $6 \mathrm{~m}$ beyond the long dimension edge of each new concrete vault). This cap includes an asphalt layer and has a design life of 500 years. Beneath the surface cap is a sund-gravel capillary break. The sand layer is assumed to be 1 meter thick. A gravel layer is built up 3 meters at the apex and with a 2\% slope to support the surface cap. This height assures that the waste packages are greater than 5 meters below the surface (per 10 CFR 61 requirements).

For the white paper calculations the surfice cap and the sand-capillary break were assumed to be replaced by the natural surrounding, vegetated, surface layer - Burbank loamy sand. Therefore, a constant infiltration rate for Burbink loamy sand $(4.2 \mathrm{~mm} / \mathrm{y})$ into the top of the trench or vault is assumed for the base analysil case. This value is consistent with the upper bound performance estimate for the surface cap (see Table 3.7). This assumption is conservative since it introduces water into the facility soone and thereby shortens the transport time to the aquifer. The sensitivity of the release rate to recharge is investigated with a constant recharge rate of $0.9 \mathrm{~mm} / \mathrm{y}$. 
DOE/ORP-2000-19, REV. 0

Reference: DOE/ORP-2000-07, REV. 0

Table 3.6 Summary of Best Estimate Parameters for LAWABP1 Glass

\begin{tabular}{|c|c|c|c|c|}
\hline Parameter & Meaning & Value & $\begin{array}{c}\text { Test } \\
\text { Method } \\
\text { Met }\end{array}$ & $\begin{array}{c}\text { Evaluation } \\
\text { Method }\end{array}$ \\
\hline \multicolumn{5}{|c|}{ Kinetic Rate Law Parameters } \\
\hline$\overline{\boldsymbol{k}}$ & intrinsic rate constant & $3.5 \times 10^{5} \mathrm{~g} \mathrm{~m}^{-2} \mathrm{~d}^{-1}$ & SPFT & $\begin{array}{l}\text { Substitution of } \\
\text { regressed } \\
\text { coefficients } \\
\end{array}$ \\
\hline$K_{z}$ & $\begin{array}{l}\text { apparent equilibrium } \\
\text { constant for glass based } \\
\text { on activity product } \\
\mathrm{a}\left[\mathrm{AlO}_{2}\right] \cdot \mathrm{a}\left[\mathrm{SiO}_{2}(\mathrm{aq})\right]\end{array}$ & $3.6 \times 10^{-10}$ & SPFT & Linear regression \\
\hline $\bar{\eta}$ & $\begin{array}{l}\text { pH power law } \\
\text { coefficient }\end{array}$ & 0.5 & SPFT & Linear regression \\
\hline$\overline{E_{a}}$ & $\begin{array}{l}\text { activation energy of } \\
\text { glass dissolution } \\
\text { reaction }\end{array}$ & $75 \mathrm{~kJ} / \mathrm{mol}$ & SPFT & $\begin{array}{l}\text { Nonlinear } \\
\text { regression }\end{array}$ \\
\hline$\sigma$ & Temkin coefficient & 1 & & LD6-5412 data \\
\hline$r_{x}$ & Na ion-exchange rate & $3.5 \times 10^{-7} \mathrm{~mol} /\left(\mathrm{m}^{2} \mathrm{~d}\right)$ & SPFT & Linear regression \\
\hline \multicolumn{5}{|c|}{ Secondary Mineral Phases } \\
\hline $\log _{10} K_{1}$ & $\overline{\mathrm{Al}(\mathrm{OH})_{3}(\mathrm{am})}$ & -13.10 & $\mathbf{P C T}^{(0)}$ & $\begin{array}{l}\log K \text { adjusted to }_{\text {fit PCT data }} \\
\text { fit }\end{array}$ \\
\hline $\log _{10} K_{2}$ & Analcime & -9.86 & PUF $^{(0)}$, VHT $^{(0)}$ & $\mathrm{EQ} 3 / 6$ database ${ }^{(0)}$ \\
\hline $\log _{10} K_{3}$ & Anatase & -6.64 & PCT, PUF ${ }^{(0)}$ & $\begin{array}{l}\log K \text { adjusted to } \\
\text { fit PCT data }\end{array}$ \\
\hline $\log _{10} K_{4}$ & Baddeleyite & -9.29 & PCT & EQ3/6 database ${ }^{(0)}$ \\
\hline $\log _{10} K_{3}$ & Goethite & -11.09 & $\overline{\text { PCT }}$ & EQ3/6 database ${ }^{(\mathrm{d})}$ \\
\hline $\log _{10} K_{6}$ & Herschelite & -40.94 & PUF & Polymer model \\
\hline $\log _{10} K_{7}$ & $\mathrm{La}(\mathrm{OH})_{3}(\mathrm{am})$ & 22.55 & $\overline{\text { PCT }}$ & $\begin{array}{l}\log \bar{K} \text { adjusted to } \\
\text { fit PCT data }\end{array}$ \\
\hline $\log _{10} K_{8}$ & Nontronito-K & -43.70 & PUF & EQ3/6 database ${ }^{(\mathrm{d})}$ \\
\hline $\log _{10} K$ & Nontronite-M & -43.36 & PUF & EQ3/6 database (d) \\
\hline $\log _{10} K_{10}$ & \begin{tabular}{|l} 
Nontronite-Na \\
\end{tabular} & -43.33 & PUF & EQ3/6 database $e^{(1)}$ \\
\hline $\log _{10} K_{11}$ & $\mathrm{PuO}_{2}$ & -5.18 & & EQ3/6 database (a) \\
\hline $\log _{10} K_{12}$ & \begin{tabular}{|l|} 
Sepiolite \\
\end{tabular} & 31.29 & PCT & EQ3/6 database $e^{(\pi)}$ \\
\hline $\log _{10} K_{13}$ & $\mathrm{SiO}_{2}(\mathrm{am})$ & -2.85 & PUF,PCT & EQ3/6 database $e^{(\mathrm{d})}$ \\
\hline $\log _{10} K_{14}$ & Soddyite & -20.24 & & EQ3/6 database (a) \\
\hline $\log _{10} K_{15}$ & $\mathrm{Zn}(\mathrm{OH})_{2}(\mathrm{am})$ & 14.44 & $\overline{\text { PCT }}$ & $\begin{array}{l}\log \bar{K} \text { adjusted to } \\
\text { fit PCT data }\end{array}$ \\
\hline $\log _{10} K_{16}$ & $\mathrm{Na}-\mathrm{Zn}-\mathrm{Ti}-$ silicate (TBD) & Unknown & PUF $^{(0)}$ & Not evaluated \\
\hline
\end{tabular}

(a) See MoGrail 1999 for definition of different tests types

(B) Unless otherwise noted, solid phase infarred from modeling - not directly observed.

(o) Solid phase identified from direct observation of reacted solids

(d) BQ3/6 Ref??? 


\section{DOE/ORP-20Q0-19, REV. 0 \\ Reforence: DOE/ORP-2000-07, REV.0}

The trench and vault dimensions are as defined in Section 2.2. The leachate collection systems are ignored in the moisture and transport modeling. The leachate collection systems can be ignored because of the relatively short design life for these material (less than 500 years for concrete and 100 years for HDPE) compared to the travel time through the vadose zone $(1,000-$ 2,000 years). The 1998 ILAW PA (Mann 1998a) examined the potential impact of the concrete vault trapping water and then failing ("bathtub effect"). The analysis showed little effect on the estimated impacts at the time of compliance. The material between the packages in the trench (or vault) is assumed to be backfill material as defined in Meyer (1999). Additional details on the numerical model calculations for the facility can be found in Sections 3.5.2, 3.5.3, and 3.5.4.

\subsubsection{Infiltration Rate}

The term recharge is used to denote the rate at which moisture flows past the root zone (that is, very near surface) into a region where moisture flow follows simpler models. Recommendations for recharge rates are taken from Recharge Data Package for the Immobilized Low-Activity Waste 2001 Performance Assessment (Fayer 1999), and are also provided in Appendix J of Mann/Puigh (2000). Long-term estimates of moisture flux through a fully functional surface cover, the cover side slope, and the immediate surrounding terrain, as well as for degraded cover conditions are needed. These estimates were derived from lysimeter and tracer measurements collected by the II.AW PA activity and by other projects combined with a modeling analysis.

Values for the recharge are given in Table 3.7. Values are given for two separate surface soils, Rupert sands and Burbank loamy sands. The Rupert sands are located at the site of the existing grout vaults and at the southernmost $60 \%$ of the new ILAW disposal site. The Burbank loamy sand is located at the northernmost $40 \%$ of the new IIAW disposal site. Impacts from degradation of the surface barrier, vegetation change, climate change, and irrigation were considered in establishing the best estimate and bounding values.

Table 3.7 Recharge Rate Estimates (mm/year) ${ }^{(a)}$

\begin{tabular}{|l|l|l|l|}
\hline Surface feature & Pre-Hanford & Construction & $\begin{array}{l}\text { Cover and Post Cover } \\
\text { Design Life }\end{array}$ \\
\hline Surface cover & na & na & $\begin{array}{l}0.1 \\
(0.01,4.0)\end{array}$ \\
\hline Cover side slope & na & na & $\begin{array}{l}50 \\
(4.2,86.4)\end{array}$ \\
\hline Rupert sand & 0.9 & 0.9 & 0.9 \\
& $(0.16,4.0)$ & $(0.16,4.0)$ & $(0.16,4.0)$ \\
\hline Burbank loamy sand & 4.2 & 4.2 & 4.2 \\
& $(2.8,5.5)$ & $(2.8,5.5)$ & $(2.8,5.5)$ \\
\hline Construction & ma & 55.4 & na \\
& & $(50,86.4)$ & \\
\hline
\end{tabular}

(a) best estimate case given, with values for reasonable bounding cases given in parentheses; na = not applicable 


\section{DOE/ORP-2000-19, REV. 0 \\ Reference: DOE/ORP-2000-07, REV. 0}

For the base analysis case we have assumed the conservative position that the surface barrier has failed shortly after it was installed and used the recharge rate for Burbank loamy sand for just below the RCRA subtitle C surface cap.

\subsubsection{Exposure Parameters}

Dosimetry scenarios and parameter values are based on the discussion and values presented in Dasimetry Data Package for the Hanford Immobilized Low-Activity Tank Waste Performance Assessment (Rittmann 1999), and also appendix O of Mann/Puigh (2000). The scenarios for human exposure to the hazardous materials associated with the ILAW glass are defined in appendix B (Mann, 1999b). Table 3.8 provides the unit dose factors (mrem per $\mathbf{C i}$ exhumed) for the intrusion scenario where a post-intrusion resident lives near the exhumed waste associated with a well drilled through the disposal site. Table 3.9 provides the total unit dose factors for five exposure scenarios where the exposure includes contamination of the groundwater. These scenarios are for industrial, residential, agricultural, and population exposures as defined in the Hanford Site Risk Assessment Methodology (HSRAM) (DOE/RL 1991). The Native American subsistence resident exposure is discussed in DOE/RL (1997).

Table 3.8 Annual Unit Dose Factors for Post-Intrusion Resident (mrem per Ci exhumed)

\begin{tabular}{|l|c|c|}
\hline Radiouclide & External & Intermal \\
\hline $\mathrm{H}-3$ & 0.0 & $1.46 \times 10^{2}$ \\
\hline Se-79 & $4.24 \times 10^{-2}$ & $1.24 \times 10^{2}$ \\
\hline Sr-90+D & $5.15 \times 10^{1}$ & $2.00 \times 10^{4}$ \\
\hline Tc-99 & $1.69 \times 10^{-1}$ & $7.93 \times 10^{2}$ \\
\hline Sn-126+D & $2.41 \times 10^{4}$ & $1.05 \times 10^{2}$ \\
\hline $\mathrm{I}-129$ & $2.58 \times 10^{1}$ & $6.70 \times 10^{3}$ \\
\hline $\mathrm{Cs}-137+\mathrm{D}$ & $6.80 \times 10^{3}$ & $1.23 \times 10^{3}$ \\
\hline Pa-231 & $4.78 \times 10^{2}$ & $3.81 \times 10^{4}$ \\
\hline $\mathrm{U}-233$ & 3.21 & $2.74 \times 10^{3}$ \\
\hline $\mathrm{U}-234$ & $9.04 \times 10^{-1}$ & $2.68 \times 10^{3}$ \\
\hline $\mathrm{U}-235+\mathrm{D}$ & $1.66 \times 10^{3}$ & $2.51 \times 10^{3}$ \\
\hline $\mathrm{U}-236$ & $4.81 \times 10^{-1}$ & $2.54 \times 10^{3}$ \\
\hline $\mathrm{U}-238+\mathrm{D}$ & $2.61 \times 10^{2}$ & $2.45 \mathrm{E} \times 10^{3}$ \\
\hline $\mathrm{Np}-237+\mathrm{D}$ & $2.30 \times 10^{3}$ & $2.39 \times 10^{4}$ \\
\hline Pu-239 & $6.48 \times 10^{-1}$ & $1.18 \times 10^{4}$ \\
\hline $\mathrm{PU}-240$ & $3.34 \times 10^{-1}$ & $1.18 \times 10^{4}$ \\
\hline $\mathrm{Am}-241$ & $9.98 \times 10^{1}$ & $1.23 \times 10^{4}$ \\
\hline
\end{tabular}


DOE/ORP-2000-19, REV. 0

Reference: DOE/ORP-2000-07, REV. 0

Table 3.9. Total Annual Unit Dose Factors for Low-Water Infiltration Cases (mrem per pCi/L in the groundwater)

\begin{tabular}{|c|c|c|c|c|c|}
\hline Nuclide & $\begin{array}{l}\text { HSRAM } \\
\text { Industrial }^{(a)}\end{array}$ & $\begin{array}{l}\text { HSRAM } \\
\text { Residential ( }\end{array}$ & $\begin{array}{l}\text { All Pathways } \\
\text { Farmer }^{(a)}\end{array}$ & $\begin{array}{l}\text { Native } \\
\text { American } \\
\text { Sustenance } \\
\text { Resident (o) }\end{array}$ & $\begin{array}{l}\text { Columbia } \\
\text { River } \\
\text { Population }\end{array}$ \\
\hline H-3 & $1.62 \times 10^{-3}$ & $4.92 \times 10^{-3}$ & $4.58 \times 10^{-5}$ & $1.03 \times 10^{-4}$ & $2.29 \times 10^{-1}$ \\
\hline Se-79 & $2.18 \times 10^{3}$ & $7.26 \times 10^{-5}$ & $1.15 \times 10^{-2}$ & $3.10 \times 10^{-2}$ & $5.03 \times 10^{1}$ \\
\hline Sr-90+D & $3.83 \times 10^{-2}$ & $1.30 \times 10^{-1}$ & $1.19 \mathrm{E}-01$ & $3.38 \times 10^{-1}$ & $5.53 \times 10^{2}$ \\
\hline Tc-99 & $3.65 \times 10^{-4}$ & $1.31 \times 10^{-3}$ & $3.54 \times 10^{-3}$ & $1.23 \times 10^{-2}$ & $1.46 \times 10^{I}$ \\
\hline Sn-126+D & $5.28 \times 10^{-3}$ & $4.07 \times 10^{-2}$ & $5.63 \times 10^{-2}$ & $1.20 \times 10^{-1}$ & $2.36 \times 10^{2}$ \\
\hline $\mathrm{I}-129$ & $6.90 \times 10^{-2}$ & $2.31 \times 10^{-1}$ & $3.77 \times 10^{-1}$ & 1.21 & $1.64 \times 10^{3}$ \\
\hline$C_{8}-137+D$ & $1.25 \times 10^{-2}$ & $4.84 \times 10^{-2}$ & $7.53 \times 10^{-2}$ & $2.14 \times 10^{-1}$ & $3.25 \times 10^{2}$ \\
\hline$P a-231$ & 2.68 & 8.87 & 7.08 & $1.84 \mathrm{E}+01$ & $3.40 \times 10^{4}$ \\
\hline U-233 & $7.51 \times 10^{-2}$ & $2.45 \times 10^{-1}$ & $2.19^{-1}$ & $5.77 \times 10^{-1}$ & $1.04 \times 10^{3}$ \\
\hline $\mathrm{U}-234$ & $7.35 \times 10^{-2}$ & $2.40 \times 10^{-1}$ & $2.14 \times 10^{-1}$ & $5.65 \times 10^{-1}$ & $1.02 \times 10^{3}$ \\
\hline $\mathrm{U}-235+\mathrm{D}$ & $6.93 \times 10^{-2}$ & $2.28 \times 10^{-1}$ & $2.03 \times 10^{-2}$ & $5.34 \times 10^{-1}$ & $9.62 \times 10^{2}$ \\
\hline U-236 & $6.99 \times 10^{-2}$ & $2.28 \times 10^{-1}$ & $2.04 \times 10^{-1}$ & $5.37 \times 10^{-1}$ & $9.65 \times 10^{2}$ \\
\hline $\mathrm{U}-238+\mathrm{D}$ & $6.95 \times 10^{-2}$ & $2.27 \times 10^{-1}$ & $2.03 \times 10^{-1}$ & $5.34 \times 10^{-1}$ & $9.60 \times 10^{2}$ \\
\hline $\mathrm{Np}-237+\mathrm{D}$ & 1.12 & 3.72 & 2.97 & 7.73 & $1.42 \times 10^{4}$ \\
\hline Pu-239 & $8.94 \times 10^{-1}$ & 2.96 & 2.36 & 6.14 & $1.13 \times 10^{4}$ \\
\hline $\mathrm{Pu-240}$ & $8.94 \times 10^{-1}$ & 2.96 & 2.36 & 6.14 & $1.13 \times 10^{4}$ \\
\hline Am-241 & $9.19 \times 10^{-1}$ & 3.05 & 2.43 & 6.32 & $1.17 \times 10^{4}$ \\
\hline
\end{tabular}

(a) Annual dose in mrem for a groundwater concentration of $1 \mathrm{pCi} / \mathrm{L}$

(b) Annual dose in person-rem per Columbia River concentration of $1 \mathrm{pCi} / \mathrm{L}$

\subsection{Performance Assessment Methodology}

\subsubsection{Introduction}

Computer codes will be used for four purposes:

- to calculate contaminant release rates from the waste packages and from the disposal facility,

- to calculate moisture flow and contaminant transport in the vadose zone,

- to calculate moisture flow and contaminant transport in groundwater, and

- to merge the results of the preceding codes.

Figure 3.5 illustrates also the overall computational strategy for the ILAW PA. The near-field environment is defined as the domain through the trench or vault to some distance below the floor of the disposal facility. A coupled unsaturated flow, chemical reactions, and contaminant transport simulator (STORM) was used within the near-field (Bacon 2000). The plume exiting the region near the vault is expected to be of high ionic strength and $\mathrm{pH}$, and will migrate down into the near-field vadose zone for some distance. However, at some distance from the disposal vaults, geochemical conditions will approach hose more typical of the Hanford vadose zone and for which simplifying assumptions (such as linear sorption, negligible precipitation/dissolution, 


\section{DOE/ORP-2000-19, REV. 0 \\ Befferenc: DOE/ORP-2000-07, REV. 0}

no changes in hydraulic properties, and no fluid density gradient effects) can be used. This region is defined as the far-field environment and can be simulated using standard, non-reactive (chemical reactions not specifically included in calculations) flow and transport codes. For the ILAW PA, computations in the far-field domain were done using VAM3DF (Huyakom and Panday 1995), a variably saturated flow and transport code.

The primary reason for switching from the near-field simulator to VAM3DF is to apply a less complicated code for the far-field, and therefore a faster turnaround for the numerical simulations. The radionuclide flux exiting the far-field domain to the unconfined aquifer will be provided by VAM3DF and will be used as a boundary condition for the unconfined aquifer flow and transport simulator. Calculations in the groundwater aquifer are performed using the Hanford Site model and associated code, CFEST-96, (Gupta 1987). The Hanford Site Groundwater Program has recommended this code for performing saturated flow and transport simulations for the Hanford Site. Finally, the results of each of the sequential calculations are combined to estimate the impacts from the disposal system using the INTEG program (Mann 1996b). This program combines the results from the far field calculations, the groundwater calculations, and the dosimetry data to estimate impacts related to the performance objectives.

\subsubsection{Base Analysis Case and Sensitivity Case Descriptions}

A base analysis case has been chosen to represent the ILAW disposal system. It was assumed that the ILAW waste is disposed in a remote handled trench having the dimensions outlined in Figure 2.4 and provided in Puigh (1999). The effect of the modified RCRA subtitle C surface cap above the trench and the sand-gravel capillary break are ignored. A recharge rate of $4.2 \mathrm{~mm} / \mathrm{y}$ into the facility is assumed (see section 3.4.5). Backfill hydraulic properties (Table 3.2) are used for the filler material between the waste packages in the trench. Similarly the layer below the trench is modeled as having the properties of the Hanford sandy sequence (see Table 3.3). The far field is modeled as having two major sequences: a sandy sequence and a gravelly sequence. The hydraulic properties for these sequences are provided in Table 3.3. Similarly, the chemical properties of these sequences are provided in Table 3.4. Additional details are provided in sections 3.5.3 and 3.5.4. For the groundwater calculations the RH trenches were assumed to be in the southeast comer of the IIAW disposal site (see Figure 2.2). This location provides a conservative estimate for the dilution of the contaminants in the groundwater since part of the aquifer is in the Ringold Formation, which has lower conductivity and hence lower flow. Also, the 200 Area fence is approximately $100 \mathrm{~m}$ downgradient from the facility at this location within the disposal site.

Several sensitivity cases were also run to provide the reader with an estimate of the relative impact of key assumptions. One sensitivity case explores the impact of a different recharge rate $(0.9 \mathrm{~mm} / \mathrm{y})$ into the facility. A value of $0.9 \mathrm{~mm} / \mathrm{y}$ is used as a sensitivity case based on the natural recharge for Rupert sand and surface barrier performance considerations (see section 3.4.5). A second sensitivity case has been set up assuming a concrete vault layout. This case also has a higher loading of waste into the vault when compared to the RH trench. All calculations are performed for the ILAW inventory in the waste form (see Table 3.1). The sensitivity of the results compared to the performance objectives to uncertainties in the inventory is also investigated. 


\section{DOE/ORP-2000-19, REV. 0 \\ Refernce: DOE/ORP-2000-07, REV.0}

Figure 3.5 Modeling Strategy for Assessing ILAW Disposal System

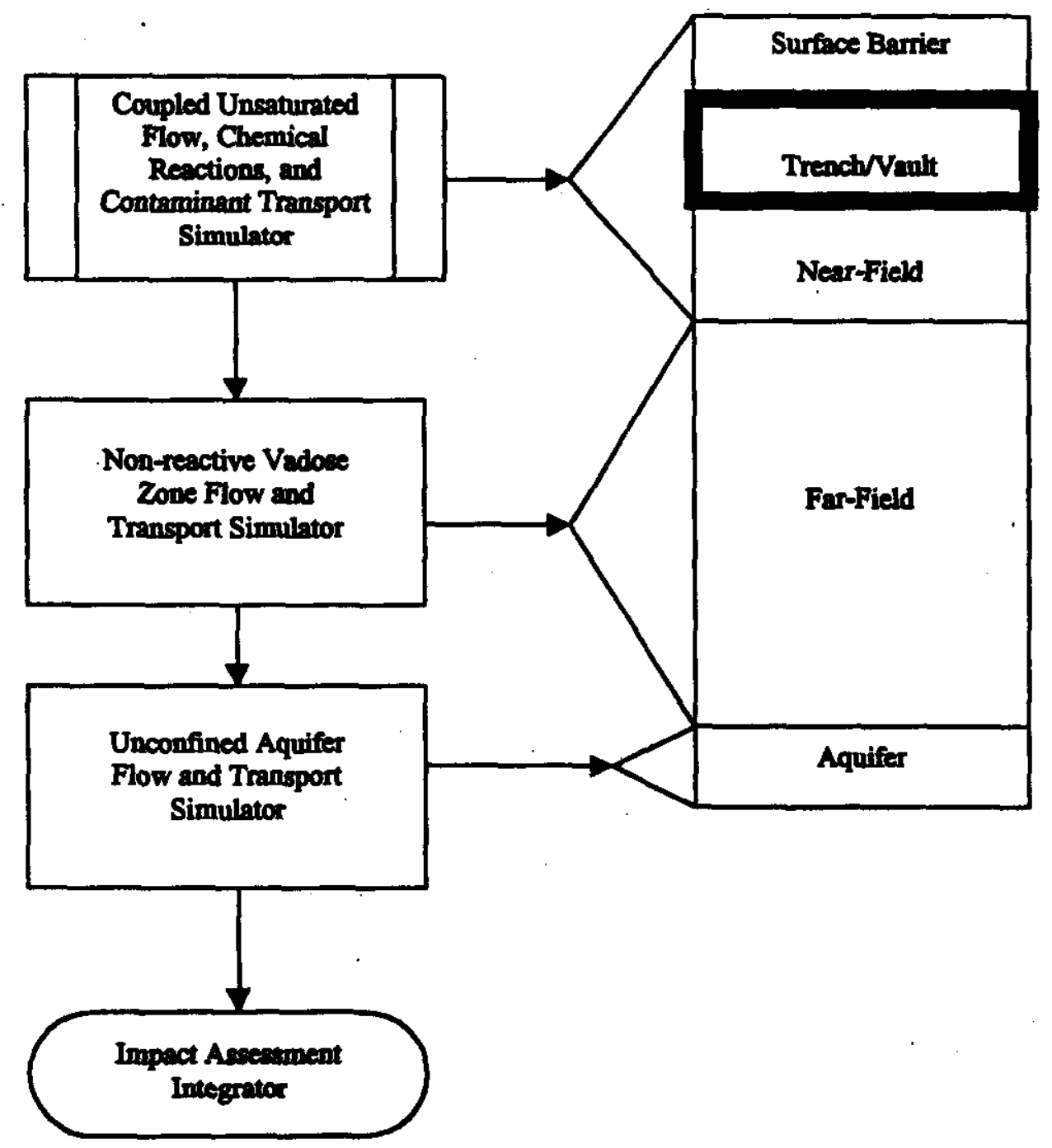

For each case the waste form calculation is performed out to at least 20,000 years. The output from the waste form calculation is the itput to the far-field calculation that calculates the flux to the groundwater below the trench or valt. Finally the groundwater calculation provides the dilution factor (well intercept factor) to a potential receptor either $100 \mathrm{~m}$ downgradient from the trench or vault, to the 200 area fence, or to the closest flow path to the Columbia River.

- The waste form calculations are performed for "Tc release from LAWABP1 glass. The flux concentration of other radionuclides and hazardous chemicals into the far-field is assumed A- 49 


\section{DOE/ORP-2000-19, REV. 0 \\ Referenci: DOE/ORP-2000-07, REV. 0}

to be proportional to their concentration in the waste form relative to ${ }^{99} \mathrm{Tc}$. This assumption assumes that the release of each hazardous radionuclide or chemical is proportional to the dissolution rate of the glass and that none of these released isotopes or chemicals interact with the near field materials except as identified in Table 3.5. This approach is conservative because it neglects any secondary phase formation that might occur and trap these contaminants. Chemical adsorption using the $\mathrm{K}_{d}$ model described in section 3.4.2.3 is used for the transport of these other materials through the vadose zone. The $\mathrm{K}_{d}$ value for the hazardous chemicals is conservatively assumed to be zero.

\subsubsection{Waste Form Release and Near-Field Contaminant Transport Code Calculations}

\subsubsection{Approach and Rationale}

The 1998 ILAW PA showed that the key variable in the analysis is the waste form release rate, which must be calculated over thousands of years. To conduct this calculation, we have pursued a methodology where the waste form release rate is evaluated by modeling the basic physical and chemical processes that are known to control dissolution behavior instead of using empirical extrapolations from laboratory "leaching" experiments commonly used in other performance assessments. We adopted this methodology for the following reasons:

- The dissolution rate, and hence radionuclide release rate from silicate glasses is not a state function, i.e. a constapt that can be derived independent of other variables in the system. Glass dissolution rate is a function of three variables (neglecting glass composition itself): temperature, $\mathrm{pH}$, and composition of the fluid contacting the glass. The temperature of the ILAW disposal system is a known constant. However, both $\mathrm{pH}$ and composition of the fluid contacting the glass are variables that are affected by flow rate, reactions with other engineered materials, gas-water equilibria, econdary phase precipitation, alkali ion exchange, and by dissolution of the glass itself (a classic feedback mechanism). Consequently, glass dissolutionirates will vary both in time and as a function of position in the disposal system. There is no physical constant such as a "leach rate" or radionuclide release rate parameter that can be assigned to a glass waste form in such a dynamic system.

- One of the principal purposes of the IIAW PA is to provide feedback to engineers regarding the impacts of design options on disposal system performance. A model based on empirical relesse behavior of the waste form could not provide this information. For example, we have found little effect on waste form performance regardless of whether stainless or cast steel is used for the waste form pour canister. However, significant impacts have been observed when large amounts of concrete are used in constructing vaults for ILAW. The concrete raises the pH of the pore water entering the waste packages and 20 increases glass corrosion.

Unfortunately, the robuat methodology we have employed does not come without some penalties. The principal penalty is the increased amount of information that is neoded about the reaction mechanisms controlling the dissolution behavior of the waste form. Significantly more laboratory experiments are required to parameterize the models used for our simulations. Second, the model itself is markedly more complex. Execution times with today's fastest workstations can take weeks for one- and two-dimensional simulations and three-dimensional 


\section{DOE/ORP-2000-19, REV. 0 \\ Refone: DOE/ORP-2000-07, REV. 0}

simulations can only be attempted on today's most sophisticated massively parallel computers. Still, we believe the benefits, particularly with regards to the technical defensibility of the methodology and results, far outweigh the penalties.

\subsubsection{Computer Model Selection}

The code selection criteria and selection process used is documented in Selection Of $A$ Computer Code For Hanford Low-Level Waste Engineered-System Performance Assessment (McGrail 1998\&), which is included as Appendix C of Mann/Puigh 2000. The needed capabilities were identified from an analysis of the important physical and chemical processes expected to affect LAW glass corrosion and the mobility of radionuclides. The available computer codes with suitable capabilities were ranked in terms of the feature sets implemented in the code that match a set of physical, chemical, numerical, and functional capabilities needed to asseas release rates from the engineered system. The highest ranked computer code was found to be the STORM code developed at PNNL for the U.S. Department of Energy for evaluation of arid land disposal sites. The verification studies for STORM are documented in Subsurface Transport Over Reactive Multiphases (STORM): A General, Coupled Nonisothermal Multiphase Flow, Reactive Transport, and Porous Medium Alteration Simulator, Version 2, User's Guide (Bacon 2000), which is included as Appendix D in Mann/Puigh (2000).

\subsubsection{Overview of Model Setup and Parameterization}

The remote handled trench simulations encompass a 1-D vertical profile near the center of a single trench (Figure 3.6). It is assumed that the material representing the waste packages is $85 \%$ glass, $2 \%$ stainless steel and $13 \%$ filler by volume. The unsaturated hydraulic properties for each of the porous materials considered are listed in Table 3.2 and Table 3.3. The unsaturated hydraulic properties for glass (Table 3.2) were used for the waste packages.

The new ILAW vault simulations encompass a 1-D vertical profile at the center of a single vault (Figure 3.7). It is assumed that the material representing the waste packages is 85\% glass, $2 \%$ stainless steel and $13 \%$ filler by volume. The unsaturated hydraulic properties for each of the materials considered are listod in Table 3.2. The unsaturated hydraulic properties for glass (Table 3.2) were used for the waste packages. The steel container was assumed to not provide a water barrier at the start of the simulation.

The waste package containers were assumed to consist of 304 stainless steel. The corrosion reaction for 304 stainless steel is given by Cloke (1997):

$$
\begin{aligned}
\text { Steel }+ & 2.9262 \times 10^{-2} \mathrm{H}^{+}+1.7618 \mathrm{H}_{2} \mathrm{O}+3.4169 \times 10^{-1} \mathrm{O}_{2}(\mathrm{aq}) \rightarrow \\
& 3.4667 \times 10^{-3} \mathrm{HCO}_{3}^{-}+3.4701 \times 10^{-1} \mathrm{CrO}_{4}^{2+}+1.1828 \mathrm{Fe}(\mathrm{OH})_{3}(\mathrm{aq}) \\
+ & 3.5167 \times 10^{-2} \mathrm{Mn}^{2+}+9.9093 \times 10^{-3} \mathrm{NO}_{3}+1.8583 \times 10^{-1} \mathrm{Ni}^{2+} \\
+ & 8.8004 \times 10^{-4} \mathrm{HPO}_{4}^{2}+5.2008 \times 10^{-4} \mathrm{SO}_{4}^{2}+1.7325 \times 10^{-2} \mathrm{SiO}_{2}(\mathrm{aq})
\end{aligned}
$$




\section{DOE/ORP-2000-19, REV. 0}

\section{Reference: DOE/ORP-2000-07, REV. 0}

The $304 \mathrm{~L}$ stainless steel corrosion rate was assumed to be a constant $6.87 \times 10^{-14} \mathrm{~mol} \mathrm{~cm}^{-2} \mathrm{~s}^{-1}$ Cloke (1997). This conservatively implies that the steel corrosion rate is not affected by changes in $\mathrm{pH}$ or water chemistry.

Other materials in the simulations, including vault concrete, backfill, Hanford Sand, and vault filler, contain additional solid phases. The backfill material was assumed to consist of $40 \%$ albite, 40\% quartz, 10\% K-feldspar and 10\% illite (Mann 1998a). Degraded vault concrete was assumed to consist of backfill with 15\% Portlandite added. The vault filler and Hanford Sand were assumed to have the same mineral composition as the backfill material. The dissolution reactions and equilibrium constants associated with each of these minerals are detailed in the Waste Form Release Data Package for the 2001 Immobilized Low-Activity Waste Performance Assessment (McGrail 1999).

Model grids were $5 \mathrm{~cm}$ in vertical resolution; this is slightly larger than the $3.66 \mathrm{~cm}$ grid spacing used in the 1998 ILAW PA. The time steps used in these calculations were calculated automatically by the code given a convergence criteria of $1 \times 10^{-6}$. This ensures that predicted values of aqueous species concentrations and mineral volumes are accurate to 0.0001 percent between iterations for a given time step. If this cannot be achieved within a certain number of iterations, the time steps are automatically reduced. Numerous simulations were conducted to ensure that the grid spacing and convergence criteria chosen for the simulations were small enough to ensure accuracy, yet large enough to allow the simulations to finish in a reasonable amount of time. For comparison the base case remote handled trench simulation was rerun with a grid spacing of $2.5 \mathrm{~cm}$, and also with a convergence criteria of $5 \times 10^{-7}$. Results for these simulations were not significantly different than reported herein.

The flow simulations used the following boundary conditions: constant apecified flux at the upper boundary and free drainage at the lower boundary. The reactive transport simulations used the following boundary conditions: specified aqueous species concentrations at the upper boundary and no diffusion across the lower boundary. The flux of Tc across the lower boundary is therefore limited to advection

$$
\begin{aligned}
& f=c \rho_{v} v \\
& \text { where } \quad c=\text { concentration of } \mathrm{Tc}\left(\mathrm{mol} \mathrm{kg}^{-1}\right) \\
& \rho_{w}=\text { density of water }\left(\mathrm{mol} \mathrm{m}^{-3}\right) \\
& v=\text { specific discharge }\left(\mathrm{m} \mathrm{s}^{-1}\right)
\end{aligned}
$$

The normalized Tc flux to the vedose zone is calculated by summing all Tc fluxes across the bottom boundary of the model, and normalizing the total flux according to the amount of TC in all the waste packages at the start of the simulation. The normalized flux of Tc across the lower boundary, $F$, in units of $\mathrm{ppm} / \mathrm{y}$, was calculated using

$$
F=\frac{\sum_{i=1}^{N} f_{1} \Delta x_{1} \Delta y_{1}}{I}\left(3.1558 \times 10^{7}\right)
$$

where $f_{1}=$ flux of Tc across the bottom of an individual grid block ( $\mu$ moles $\mathrm{m}^{-2} \mathrm{~s}^{-1}$ ) $\Delta x_{i} \Delta y_{1}=$ cross-sectional area of an individual grid block $\left(m^{2}\right)$ 


\section{DOE/ORP-2000-19, REV. 0}

Befrence: DOE/ORP-2000-07, REV. 0

$I=$ inventory of $\mathrm{Tc}$ in the waste packages $\left(\mathrm{mol} \mathrm{m}^{-3}\right)$, where

$I=V_{\mathrm{wp}}\left(1-\theta_{T}\right) V_{\mathrm{G}} \rho_{\mathrm{G}} \gamma_{T e}$

where

$V_{w p}=$ volume of the waste packages $\left(\mathrm{m}^{3}\right)$

$\theta_{T}=$ total porosity of the material representing the waste packages $(0.02)$

$V_{\sigma}=$ fraction of each waste package that is glass $(0.85)$

$\rho_{0}=$ molar density of LAWABP1 glass $\left(38776.1450\right.$ moles $\left.\mathrm{m}^{-3}\right)$

$\gamma_{T e}=$ mole fraction of Tc in LAWABP1 glass $\left(6.59 \times 10^{-1}\right.$ umoles Tc mole ${ }^{-1}$ glass)

The volume of the waste packages, $V_{w p}$, was $5.6 \mathrm{~m}^{3}$ for the RH Trench simulations and $8.4 \mathrm{~m}^{3}$ for the new ILAW concrete vault simulations. For 1-D simulations the cross-sectional area of the grid block was $1 \mathrm{~m}^{2}$.

Figure 3.6 Material Zones for Remote Handled Trench Waste Form Release Simulations

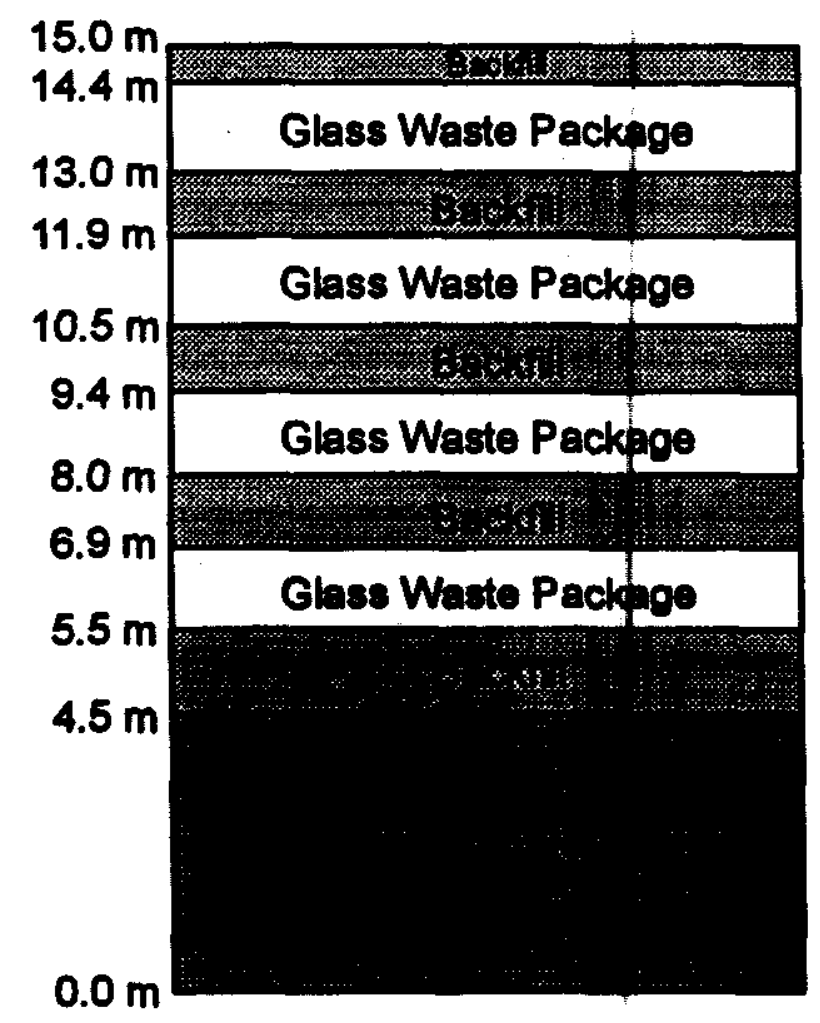


DOE/ORP-2000-19, REV. 0

Refermof: DOE/ORP-2000-07, REV. 0

Figure 3.7 Material Zones for New ILAW Vault Waste Form Release Simulations

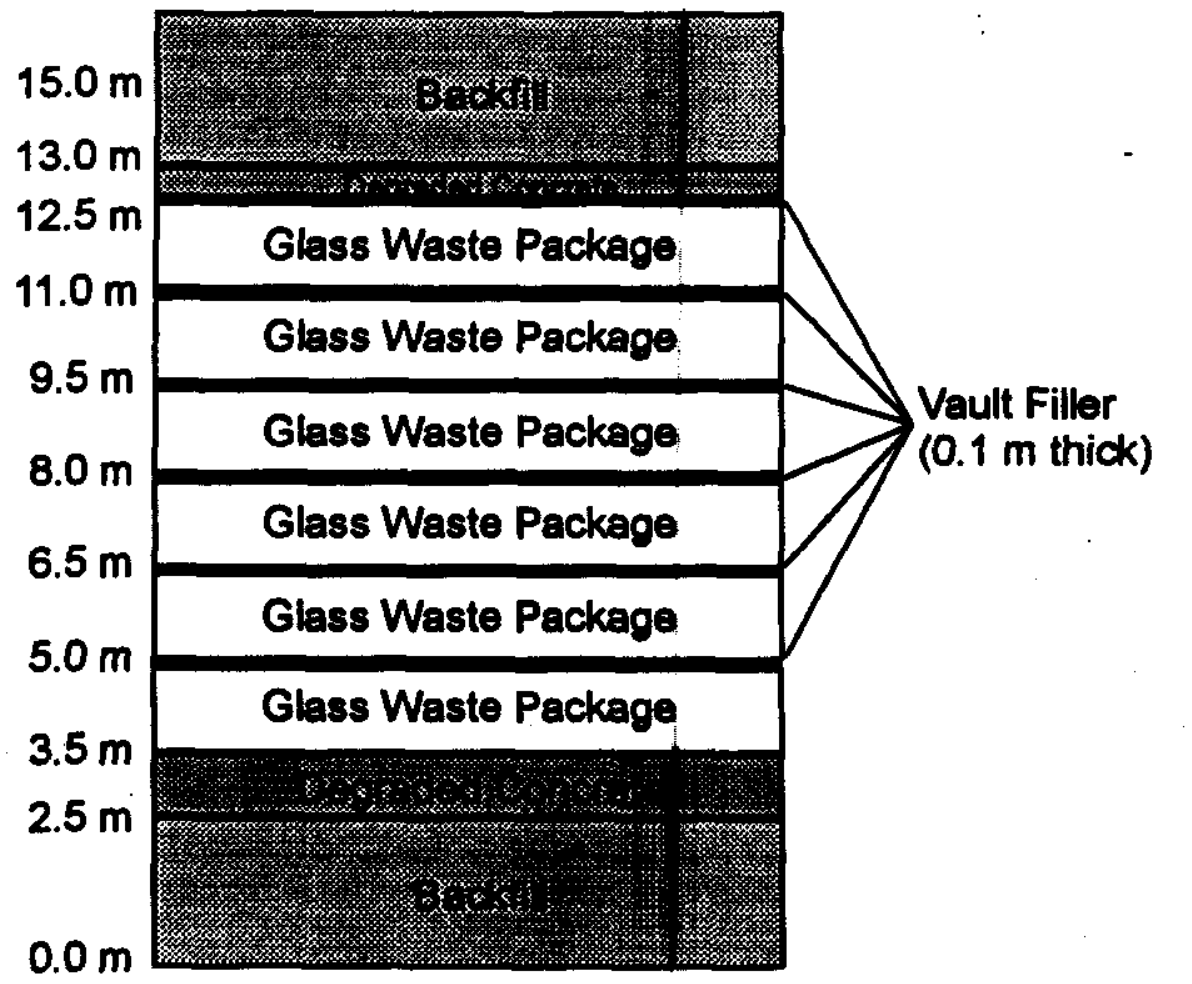

\subsubsection{Far Field Moisture Flow. and Contaminant Transport Code Calculations}

The code selection criteria for the far field (vadose zone) calculations were determined (Mann 1998b) and vendors formally submitted pyoposals which were formally evaluated (Voogd 1999). The code selection criteria were heavily basod on criteria identified for the carlier ILAW PAs (Mann 1996a) which themselves were based on DOE and NRC criteria. The VAMBDF code, an earlier version of which has been approvod by the DOE, EPA, and Washington State Department of Ecology for vadose zone calculations (TPA Milestone 29-2) was selected.

Documentation on verification of VAMBDF can be found in Appendix F of Mann/Puigh (2000).

The far field extends from the bottom of the waste disposal facilities to ground water. The material beneath the waste facilities is Hanford sand, which is projected to extend to a depth of 65 meters below surface level. Beneath the Hinford sand is the Hanford gravel that extends to the projected post-Hanford water table at 103 meters below land surface. Each material is represented as a homogeneous medium for the respective sediment types. The porous media is assumed to be isotropic, which means there is no spatial distortion caused by sedimentary layering or lateral pressure gradients in the system. Hydraulic and chemical parameters used in the model are derived from the data package of Khaleel (1999).

The fir field is simulated as a two dimentional domain, horizontally layered aystem for each of two waste disposal facility designs. The far field model is designed to correspond to the one half trench and one half vault lateral dimensions shown in Figures 2.4 and 2.7. 


\section{DOE/ORP-2000-19, REV. 0 \\ Beference: DOE/ORP-2000-07, REV. 0}

Consequently, the RH trench model domain extends 50 meters from left to right and the new II.AW vault model domain is 21.5 meters across. The upper boundary of the model domain in the far field corresponds to the lower boundary used for the waste form calculations at 15 meters below land surface. The lower boundary is located at the water table at 103 meters below land surface.

The contaminant flux along the upper boundary for the far field calculation is given by the one-dimensional contaminant flux times the quantity of waste at a given distance from the model axis (y-axis in figures). For the concrete vault the quantity of waste is constant out to the edge of the stacked packages $(10 \mathrm{~m})$. For the RH trench the average waste package stack is 4 high over the first $9 \mathrm{~m}$ from the model axis and then decreases to three then two then one package heights at the edge of the trench. For the RH trench we have assumed that the onedimensional results are applicable to a waste package stacking of two or even one package since the $\mathrm{pH}$ and the LAWABP1 dissolution rates are comparable in each of the four waste packages (see section 4.2).

The hydraulic properties of the material used in the numerical model of the near field control the flow that will reach the waste disposal facilities. Hydraulic parameters are derived from fitting a nonlinear least squares equation to an ensemble set of moisture characteristic curves for each material type used. These fitted parameters are then used as input to the model, which solves the following equations,

$\theta(h)=\frac{\theta_{s}-\theta_{r}}{\left[1+(a h)^{r}\right]^{2}}+\theta_{r}$

and

$K_{r}(h)=\frac{\left\{1-(a h)^{m}\left[1+(\alpha h)^{n}\right]^{-m}\right\}^{2}}{\left[1+(\alpha h)^{n}\right]^{m \alpha}}$

where,

$\theta=$ Volumetric water content

$\theta_{8}=$ Saturated moisture content

$\theta_{\mathrm{r}}=$ Residual moisture content

$\alpha=$ van Genuchten fitting parameter $(1 / \mathrm{cm})$

$h=$ Pressure head $(-\mathrm{cm})$

$\mathrm{n}=$ van Gemuchten fitting parameter

$m=1-1 / n$

$\mathbf{K}_{\mathbf{r}}=$ Relative conductivity $\left(\frac{K(h)}{K_{s}}\right)$

$\mathbf{K}(\mathrm{h})=$ Hydraulic conductivity $(\mathrm{cm} / \mathrm{s})$

$\mathbf{K}_{\mathbf{q}}=$ Saturated Hydrullic Conductivity $(\mathrm{cm} / \mathrm{s})$

$\ell=$ Pore connectivity $(0.5)$

The fitted hydraulic parameters for each near field material type are listed in Table 3.2. 


\section{DOE/ORP-2000-19, REV. 0 RAfenc: DOE/ORP-2000-07, REV. 0}

Fluid fluxes into the far field model are derived from fluxes that move through the near field and then through the waste disposal facilities. These volumetric fluxes are applied at the upper surface of the far field model. The lower model boundary is assigned a constant pressure head value that defines a vertical gradient that drives vertical moistuire movement. Contaminant transport from the waste facilities is a function of the fluid flow fields in the system. The contaminant is applied as a mass flux at the top of the far field, that is equivalent to the mass flux calculated beneath the facility. For all contaminant transport simulations, the far field calculation assumes the sorption coefficient, $\mathrm{K}_{\mathbf{d}}=0 \mathrm{~mL} / \mathrm{g}$ for the most mobile contaminants (defined in Table 3.4 for the radionuclides and for all the chemical contaminants. Other radionuclides are represented by adjusting the isothermal sorption coefficient $\left(\mathbf{K}_{\mathbf{d}}\right)$ which reflects the tendency of the species to sorb onto the solid sediment matrix (soe Tables 3.4 and 3.5). Contaminant inventory adjustments for other species are made by scaling to the $\mathrm{Tc}^{99}$ inventory during the integration process. See the end of section 4.2 for a description of dissolution factors used for key contaminants.

Contaminant transport in the model is calculated by the advection-dispersion equation, which is represented by the following form of the equation,

$$
\frac{\partial}{\partial x_{i}}\left(D_{i} \frac{\partial c}{\partial x_{j}}\right)-v_{i} \frac{\partial c}{\partial x_{i}}=\phi S_{v} R\left(\frac{\partial c}{\partial t}+\lambda c\right)+q\left(c-c^{*}\right)
$$

Where,

$$
\begin{aligned}
& D_{v}=\alpha_{T}|V| \delta_{i}+\left(\alpha_{L}-\alpha_{T}\right) \frac{v_{i} v_{j}}{|V|}+2 D_{0} \delta_{v} \\
& R=1+\frac{\rho_{B} k_{d}}{\phi S_{w}} \\
& D_{0}=\phi^{\frac{4}{3}} D^{*}
\end{aligned}
$$

Where,

$$
\begin{aligned}
& x_{i}=X \text {-coordinate }(\mathrm{cm}) \\
& D_{i j}=\text { Hydrodynamic dispension tensor } \\
& c=\text { Solute concentration (B) } \\
& v_{i}=\text { Darcy velocity }(\mathrm{cm} / \mathrm{s}) \\
& S_{w}=\text { Saturation fraction } \\
& R=\text { Retardation factor } \\
& q=\text { Source/sink term } \\
& c^{*}=\text { Solute concentration of injected fluid (g) } \\
& V=\text { solute volume }\left(\mathrm{cm}^{3}\right) \\
& D_{0}=\text { Bulk molecular diffusion coefficient } \\
& \left.D^{*}=\text { Free water molecular diffusion (2.5E-05 } \mathrm{cm}^{2} / 8\right) \\
& k_{d}=\text { Isothermal sorption coefficient }\left(K_{d}, \mathrm{~mL} / \mathbf{g}\right) \\
& \phi=\text { Porosity } \\
& \rho_{B}=\text { Bulk density }(\mathrm{g} / \mathrm{mL})
\end{aligned}
$$




\section{DOE/ORP-2000-19, REV. 0 \\ Beferanif: DOE/ORP-2000-07, REV. 0}

$\lambda=\quad$ First-order decay coefficient $(1 / 8)$

$\tau=$ Tortuosity

$\delta_{i j}=$ Kronecker delta

$\alpha_{\mathrm{L}}=$ Longitudinal dispersivity (cm)

$\alpha_{\mathrm{T}}=$ Transverse dispersivity $(\mathrm{cm})$

Hydraulic properties for the far field materials are listed in Table 3.3. Properties relevant to contaminant transport are listed in Table 3.10.

Table 3.10 Far Field Transport Parameters

\begin{tabular}{|l|l|l|l|l|l|l|}
\hline Media & $\alpha_{L}(\mathrm{~m})$ & $\alpha_{T}(\mathrm{~m})$ & $\alpha_{V}(\mathrm{~m})$ & $D_{0}\left(\mathrm{~m}^{2} / \mathrm{yr}\right)$ & $p_{0}\left(\mathrm{~g} / \mathrm{m}^{3}\right)$ & $\phi$ \\
\hline Sand & 2.0 & 0.2 & 0.2 & 0.0213 & $1.71 \mathrm{E}+6$ & 0.375 \\
\hline Gravel & 0.3 & 0.03 & 0.03 & 0.00562 & $2.15 \mathrm{E}+6$ & 0.138 \\
\hline
\end{tabular}

\subsubsection{Groundwater Flow and Contaminant Transport Code Calculations}

The Richland Field Manager (Wagoner 1996) has directed the Hanford Groundwater Program to establish a single groundwater model for the Hanford Site. The Henford Groundwater Program has selected CFEST as the interim code. Documentation of code formulation, user's guides, and verification are given in Gupta et al., (1987). Documentation of the specific application of the CFEST code to the site-wide groundwater flow and transport model at Hanford is provided in Wurstner et al. (1997), Cole et al. (1997), and Kincaid et al. (1998).

\subsubsection{Simulation of Site-Wide Steady-State Flow Conditions}

Past projections of post-Hanford water table conditions have eatimated the impuct of Hanford operations ceasing and the resulting clanges in artificial discharges that have been used extensively as a part of site waste-managemen practices. Simulations of transient-10w conditions from 1996 through the year 4000 where conducted by Cole ef al. (1997) with the threodimensional model shows an overall decline in the hydruulic head and hydraulic gradient across the entire water table within the modeled region. Results of these simulations were that the water table would reach steady state between 100 to 350 years in different areas over the Hanford Site.

Given the expected long delay of contuminants reaching the water from the LLW burial grounds, the hydrologic framework of all groundwater transport calculations was baced on postulated post-Hanford steady-state water talile as estimated with the throe dimenaional model. The predicted, water table for post-Hanford conditions for these assumed ateady-state conditions across the site and in the area between the ILAW New Disposal Facility and the Columbia River area illustrated in Figure 3.8 and 3.9. The ov rall flow attributes of this water table surfice are consistent with the previously simulated flow patterns described in Wurntner et al (1995), Cole et al (1997) and Law et al. (1996). From the Il AW new disposal facility, groundwater moves in a southeasterly direction near the aite and then in an easterly and northeasterty direction before discharging into the Columbia River north of the Hanford town site. 


\section{DOE/ORP-2000-19, REV. 0 \\ Refaence: DOE/ORP-2000-07, REV. 0}

\subsubsection{Local-scale Model Development and Description}

The base analysis case for the groundwater flow and transport calculations included evaluated current disposal concepts at the new II AW disposal facility that will be located in south-central 200 East area. The approach used in this analysis was to construct a local-scale model based on flow conditions calculated in the site-wide model to adequately represent flow and transport conditions near these facilities to a hypothetical well 100-m downgradient.

\subsection{Grid Design}

The grid used in the local-scale model required refinement both areally as well as vertically. The discretized grid for the local-scale model telescopes in from the grid used in regional scale calculations. The grid extends over an area of about 4100 meters in the west to east direction and $4100 \mathrm{~m}$ in the north-south direction (See Figure 3.10). It progressively varies in size from the outmost subdivided coarse triangular grids made on the regional scale $375 \mathrm{~m}$ by $375 \mathrm{~m}$ grid spaces to the finest grid spacing of 20 by $20 \mathrm{~m}$ in vicinity of the ILAW disposal area. The total number of surface elements in the three-dimensional model is 9157 elements. The three-dimensional model, based on this surface grid, comprises a total of 31604 elements (9157 surface and 22,447 subsurface elements) and 32618 nodes.

The vertical grid spacing for the transport (as well as the flow) model consisted of multiple transport layers that subdivided the major hydro-stratigraphic units. The basic approach for this subdivision is the same was used in Kincaid et al (1998) to support groundwater transport calculations used in the Composite Analysis. The basic thickness of each of these transport layers was $8 \mathrm{~m}$. The transport layers were defined from the water table surface to the basalt to account for the overall saturated thickness and to adequately represent contaminant concentrations in the three-dimensional model. At every model node each of the major hydrostratigraphic units below the water table was represented by at least one transport model layer. Nonconductive (e.g., mud units) below the water fable were always represented by at least 2 transport model layers regardless of their saturated thickness in order to assure the vertical flow and transport through these units was appropriately represented. For units whose saturated thickness was $<12 \mathrm{~m}$ thick, the layer thickness whs set to the actual saturated thickness of the unit. Nonconductive and conductive units whose saturated thickness was $>12 \mathrm{~m}$ were divided into multiple transport model layers in the same manner. For all units with thickness $>12 \mathrm{~m}$, the transport layering algorithm is as follows: create as many uniform 8-m transport layers as possible until the remaining unaccounted for saturated thickness is $>12 \mathrm{~m}$ but $<=16 \mathrm{~m}$, then create two additional transport layers set to half of the remaining saturated thickness of the hydrostratigraphic unit being layered.

At the local-scale, a total of six hydrogeologic units were found to be present: 1) the Hanford formation (unit 1) and several units belonging to the Ringold Formation, including Unit $5,6,7,8$, and 9). The three-dimensional distribution of these units in the local-scale model is depicted in Figure 3.11 . 
Figure 3.8 Predicted Water Table for Post-Hanford Conditions for Assumed Steady-State Conditions (as Simulated after 350 Years)

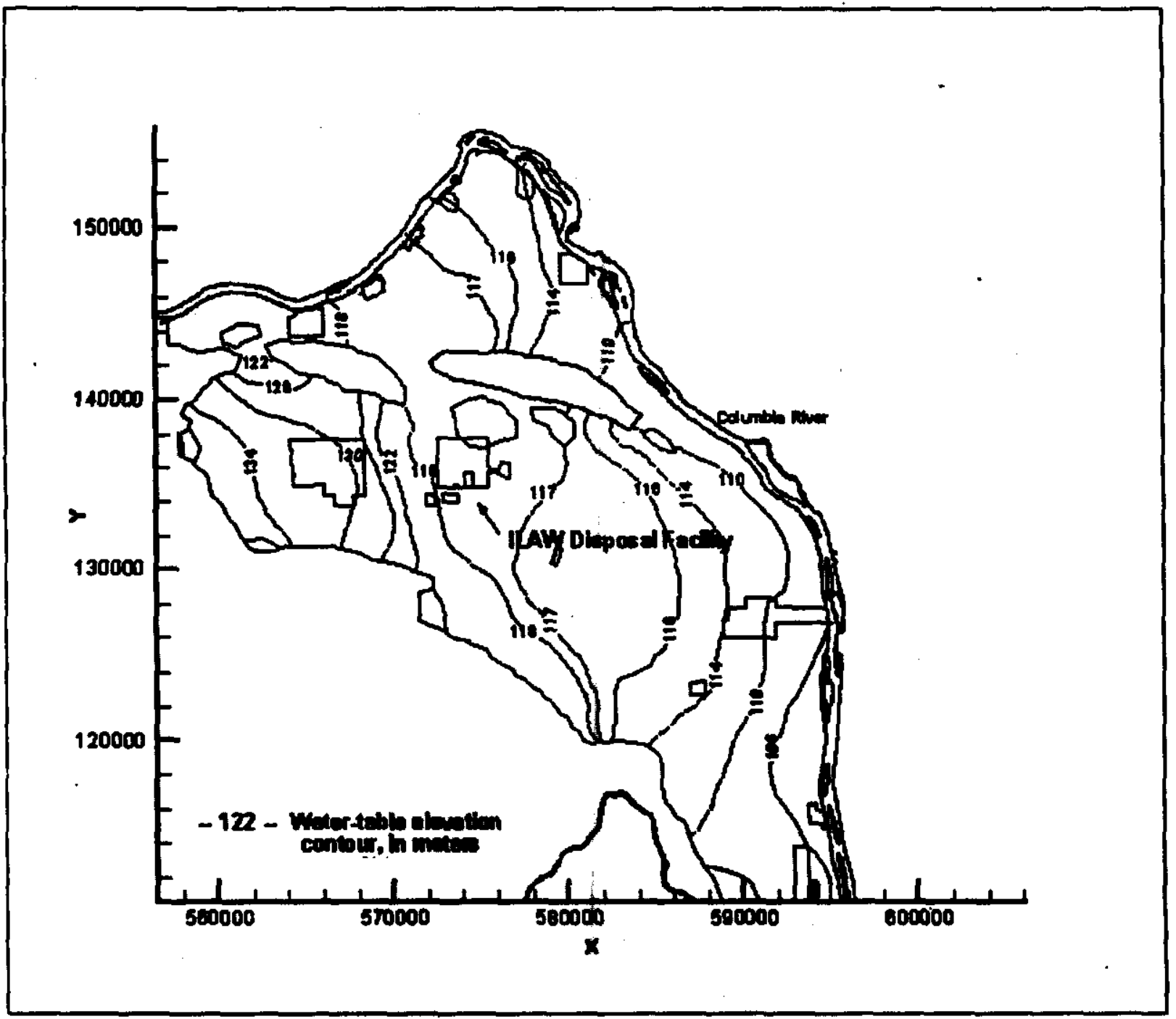

\subsection{Hydraulic Properties}

The hydraulic conductivity and porosity estimates used in the local-scale model were developed besed on the following assumption: regional scale estimates of hydrulic properties in the site-wide model can be interpolated using local-scale model grid coordinates to represent local-scale properties in vicinity of the ILAW lisposal facility area. The resulting three dimensional distribution of these properties is provided in Figure 3.12. The estimated values are, in general, indicative of the regional high trends in hydraulic properties found in the central part of the Hanford Site. 
DOE/ORP-2000-19, REV. 0

Referenc: DOE/ORP-2000-07, REV.0

Figure 3.9 Predicted Water Table for Post-Hanford Conditions for Assumed Steady-State

Conditions between IIAW Disposal Facility and Columbia River (as Simulated after 350 Yers)

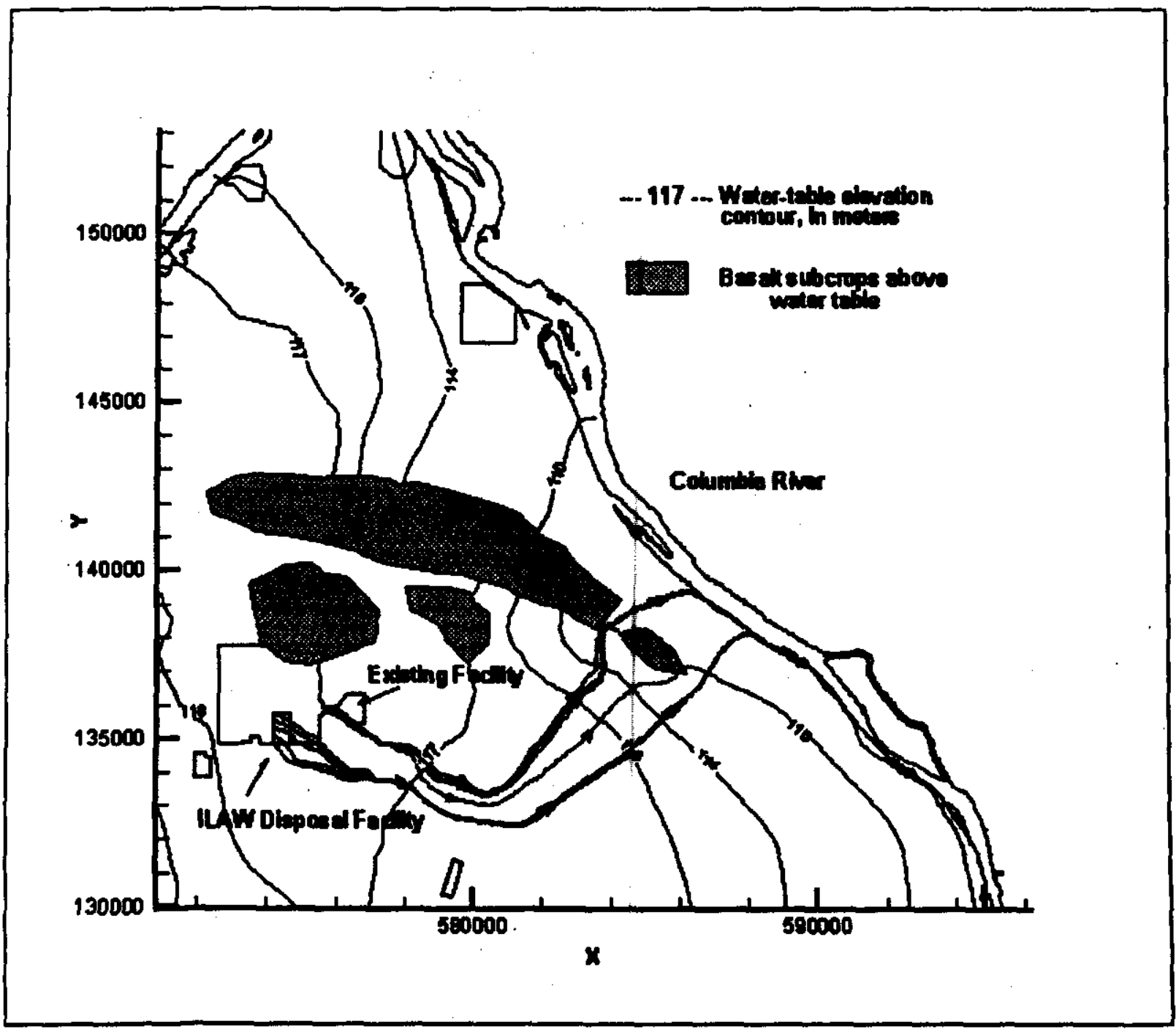

Specifically, the ancestral Columbia River deposited very coarse alluvial deposits in a deep channel extending to the south of the ILAW vite and to the north between Gable Butte and Gable Mountain. Extimated hydraulic conductivities directly below the disposal range from several thousand to tens of thousands $m$ /day in the Hanford formation and several hundred $m /$ day in the permeable parts of the Ringold Formation (Units 5, 7, and 9). Relatively low hydraulic conductivities are estimated for low permeability units within the Ringold Formation (Units 6 and 8).

The best estimate of an effective porosity of 0.25 used in the site-wide model were also used in all transport simulation made with the locil-scale model. 


\section{DOE/ORP-2000-19, REV. 0 \\ Reference: DOE/ORP-2000-07, REV.0}

Figure 3.10 Finite Element Grid Used in Local -Scale Model

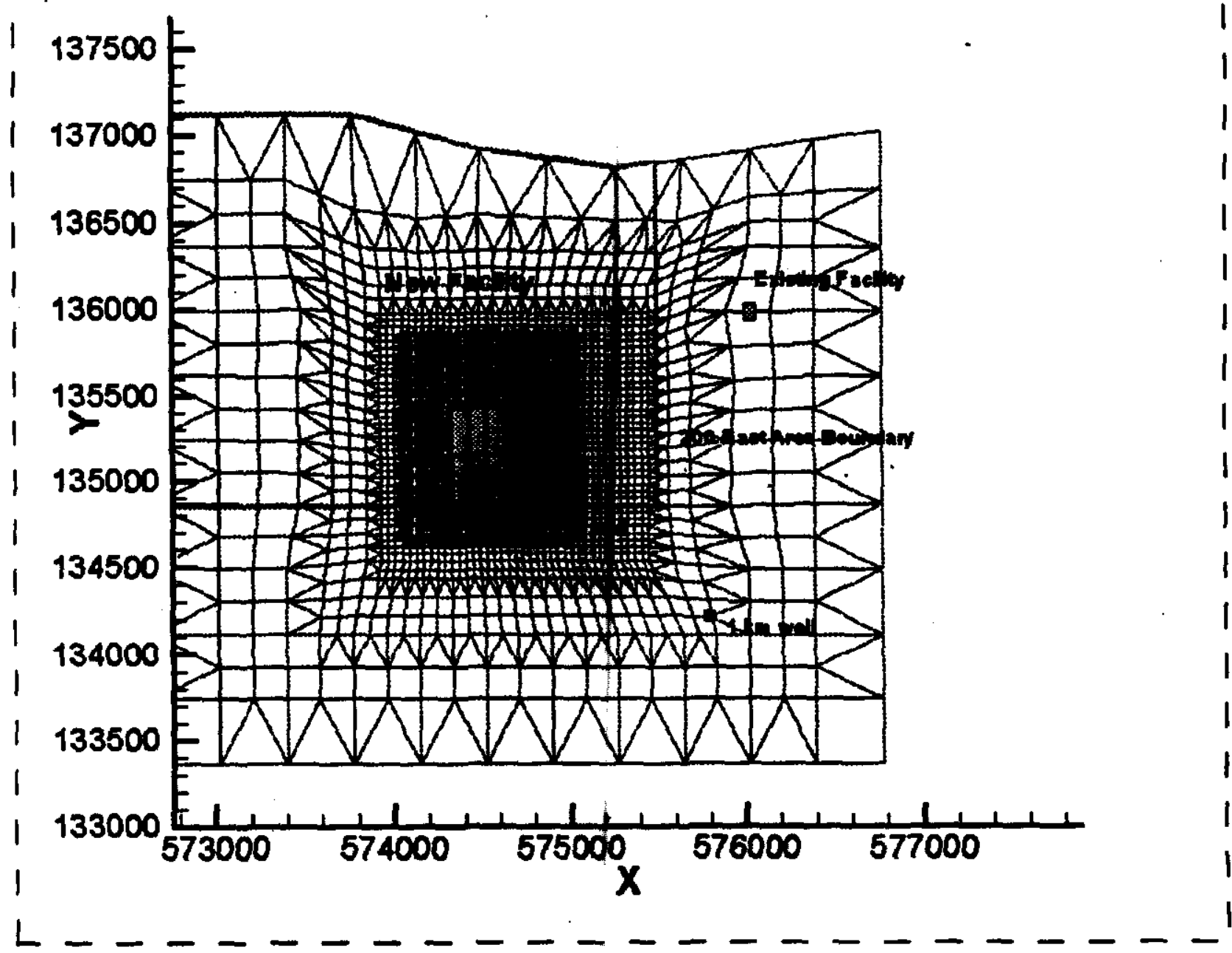

\subsection{Hydraulic Properties}

The hydruulic conductivity and porosity estimates used in the local-scale model were developed based on the following assumption; regional scale estimates of hydrullic properties in the site-wide model can be interpolated using local-scale model grid coordinates to represent local-ecale properties in vicinity of the IILAW dieposal facility area. The resulting throe dimensional distribution of these properties is provided in Figure 3.12. The estimated values are, in general, indicative of the regional high trends in hydraulic properties found in the central part of the Hanford Site. Specifically, the ancestrel Columbia River deposited very coane alluvial deposits in a deep channel extending to the sopth of the IIAW site and to the north between Gable Butte and Gable Mountain. Ectimated hydraulic conductivities directly below the disposal range from several thousand to tens of thousapds $\mathrm{m} / \mathrm{day}$ in the Hanford formation and several hundred m/day in the permeable parts of the Ringold Formation (Units 5, 7, and 9). Relatively low hydraulic conductivities are estimated for low permeability units within the Ringold Formation (Units 6 and 8). 


\section{DOE/ORP-2000-19, REV. 0 \\ Reference: DOB/ORP-2000-07, REV.0}

The best estimate of an effective porosity of 0.25 used in the site-wide model were also used in all transport simulation made with the local-scale model.

Figure 3.11 Three-Dimensional Distribution of Major Hydrogeologic Units in the Local-Scale Model

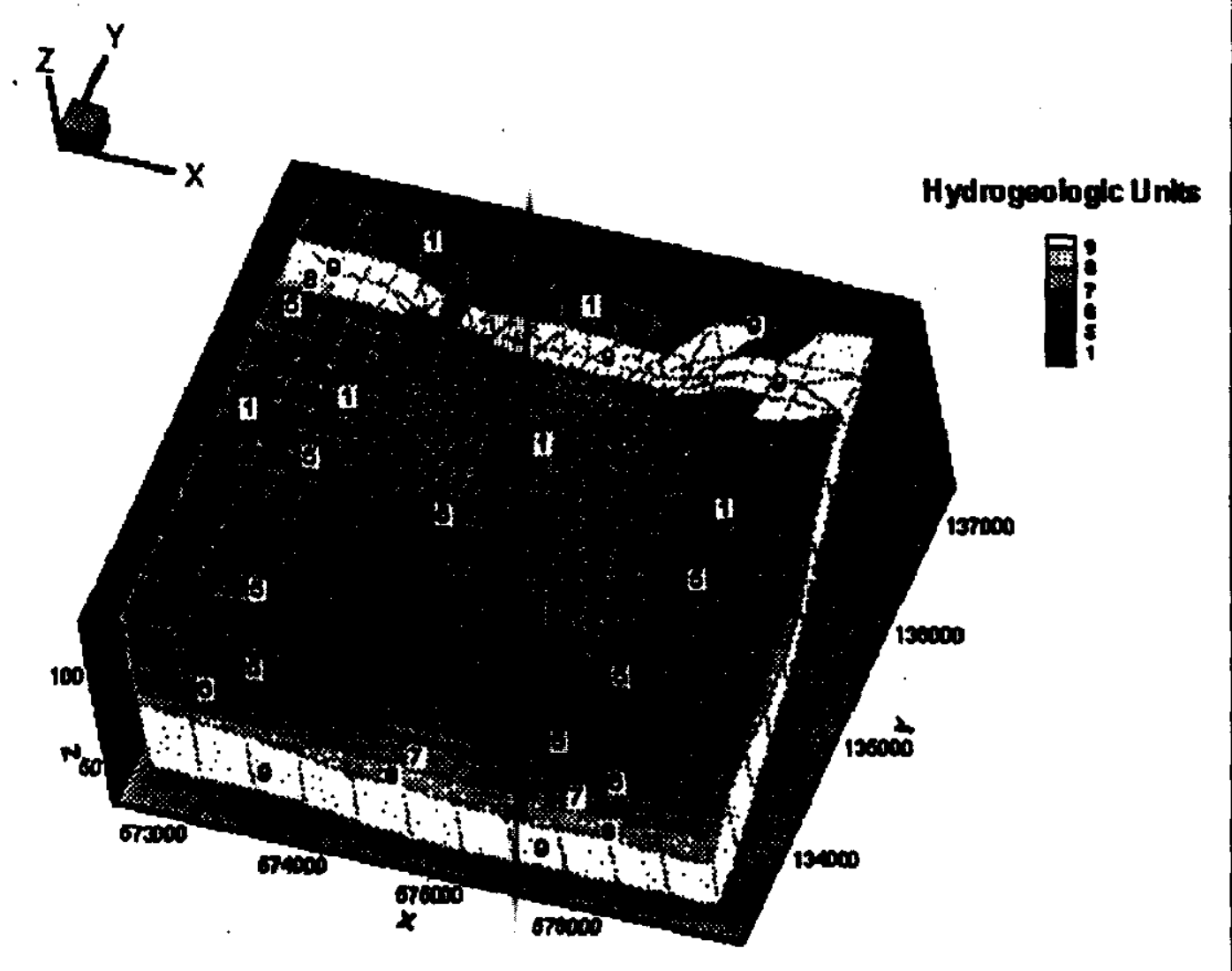

\subsection{Transport Properties}

Estimates of model parameters were developed to account for contaminant dispersion in all transport simulations. Specific model parameters examined included longitudinal and transverse dispersion coefficients $\left(D_{1}\right.$ and $\left.D_{1}\right)$ at well as estimates of effective bulk density and porosity of the aquifer materials. This section triefly summarizes estimated transport properties.

In general, the horizontal dispersivity for aquifer transport is typically set at 10 percent of the travel length in the direction of flow and the tranoverse dispersivity is et at $10 \%$ of the longitudinal value. For predictions at $100 \mathrm{~m}$ dpwngradient of the facility, this would mean a longitudinal diepersivity of at least $10 \mathrm{~m}$ would be required. For this analysis, a lower longitudinal dispersivity of $5 \mathrm{~m}$ was selected to be within the range of recommended grid peclet numbers $\left(P_{.}<4\right)$ for acceptable solutions. The $5 \mathrm{~m}$ extimate is about one-quarter of the grid 


\section{DOE/ORP-2000-19, REV. 0 \\ Reference: DOE/ORP-2000-07, REV.0}

spacing in the finest part of the local-scale model grid in the 200-Area plateau where the smallest grid spacing is on the order of $20 \mathrm{~m}$ by $20 \mathrm{~m}$. The effective transverse dispersivity was assumed to be one-tenth of the longitudinal dispersivity. Therefore, $0.5 \mathrm{~m}$ was used in all simulations.

\subsection{Base Case: Areal Sources Representing New Facility Disposal Concept}

The remote-handled trench disposal concept was evaluated in the initial base cace calculations. For this concept, the new ILAW disposal facility will consist of a set of six remotehandled waste trenches in the configuration illustrated in Figure 2.3. Each waste trench will be an underground, open-topped, trench approximately $80 \mathrm{~m}$ wide, $260 \mathrm{~m}$ long and $10 \mathrm{~m}$ deep with $3: 1$ side slopes.

The primary objective of the groundwater flow and transport calculations were to determine the well-intercept factor, The well-intercept-factor, (WIF) is defined as the ratio of the concentration at a well location in the aquifer and the concentration entering the aquifer. For purposes for these calculations, the concentration of source entering was asaumed to be $1 \mathrm{Ci} / \mathrm{m}^{3}$. The rate of mass flux associated with this concentration is a function of the infiltration rate assumed for the disposal facility covered by the modified RCRA subtitle C cap. With an assumed rate of $0.9 \mathrm{~mm} / \mathrm{y}$ assumed for the disposal facility, the resulting solute flux, which is a product of the contaminant concentration in the infiltrating water and the infiltration rate, entering the aquifer from each of the disposal concepts is $9 \times 10^{-4} \mathrm{Ci} / \mathrm{yr}^{\prime} / \mathrm{m}^{2}$.

In all model simulations performed, the WIF was calculated at a hypothetical well located approximately 100 meters downgredient from the boundary of the disposal along the centerline of the simulated plume. A pumping rate of 10 liters per day was used at the hypothetical downgradient well location. This pumping rate would provide sufficient drinking water for a family of five at an assumed intake of 2 liters per person per day. 
DOE/ORP-2000-19, REV. 0

Beferenc: DOE/ORP-2000-07, REV. 0

Figure 3.12 Distribution and Hydraulic Conductivities of Major Hydrostratigraphic Units in Local-scale Model

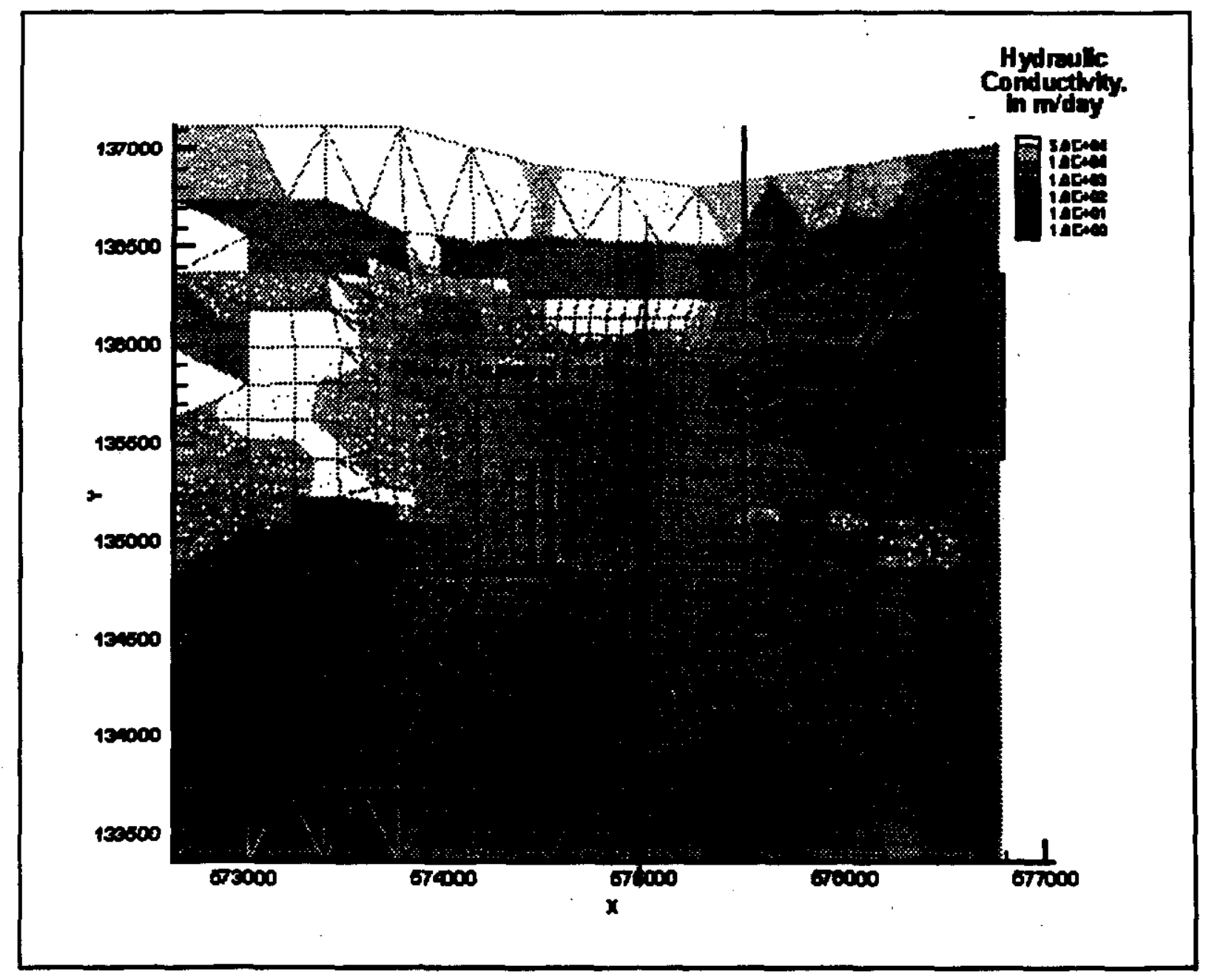

\subsubsection{Integration Calculations}

INTEG (Mann 1996b) calculates a specific impact (whether dose rate or concentration level) based on the inventory, vadose zone transport, aquifer transport, and dosimetry factors. The dose rate calculated depends on the type of dosimetry factor (e.g., all-pathways, drinking water). The program solves the following equation for each year under consideration.

$$
\text { Response }=\Sigma_{1} \frac{I_{1}(t) \Gamma_{1}(t) w_{1} D_{i}}{r A}
$$

where

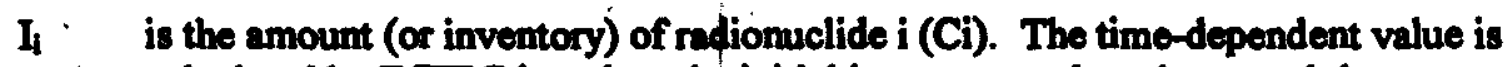
calculated by INTEG based on the initial inventory and on decay and the ingrowth from other radionuclides. 


\section{DOE/ORP-2000-19, REV. 0 \\ Reference: DOE/ORP-2000-07, REV. 0}

$\Gamma_{\mathbf{i}} \quad$ is the flux of contaminants at the bottom of the vadose zone normalized to an unit source inventory for radionuclide $\mathrm{i}([\mathrm{Ci} / \mathrm{y}] / \mathrm{Ci})$. The time-dependent value is calculated by VAM3DF.

$w_{i}$ is the ratio of the concentration of radionuclide $i$ at the well location relative to the contaminant concentration at the bottom of the vadose zone (dimensionless). This quantity was called the well intercept factor in earlier Hanford performance assessments. The peak value as calculated by CFEST is used. This value is dependent on several factors including the distance from the facility to the well, well pumping rate, and the orientation of the facility to the direction of the groundwater flow.

$D_{i} \quad$ is the dose rate factor $\left(\mathrm{mrem} / \mathrm{y}\right.$ per $\left.\mathrm{Ci} / \mathrm{m}^{3}\right)$. The values are taken from the Tables 3.8 and 3.9. $D_{i}$ is unity when the response that is calculated is a concentration.

r is the recharge rate $(\mathrm{m} / \mathrm{y})$. The value at 10,000 years is used at all analysis times.

A is the area over which the contaminant flux enters the aquifer $\left(\mathrm{m}^{2}\right)$. The value used is the area of the disposal facility being modeled.

The program is modeled after GRTPA (Rittmann 1993), which served a similar function in earlier work (Rawlins 1994). INTEG allows greater freedom in specifying data used in the integration. The code has been benchmarked against the results of GRTPA (Mann 1996b). 


\section{DOE/ORP-2000-19, REV. 0 \\ Reffence: DOE/ORP-2000-07, REV. 0}

\subsection{RESULTS OF ANALYSES}

\subsection{Overview}

This chapter presents the results of the analyses described in section 3.5. Sections 4.2 through 4.4 describe the results from the individual calculations performed for the waste form, (section 4.2), far field (section 4.3), and groundwater (section 4.4). These sections also provide the reader with an understanding of the results with respect to key parameters in each analysis. Section 4.5 summarizes the integration of these analyses and their impact on the groundwater scenarios. Section 4.6 summarizes the analyses for natural events. Finally, section 4.7 summarizes analyses for releases to the air.

\subsection{Waste Form Results}

\subsubsection{Overview}

The base analysis case calculations provided in this white paper are based on conservative, one-dimensional models for the waste form calculations. The reasons why these results are thought to be conservative are detailed at the end of this section.

Three different scenarios were considered. The base case was the RH trench with a recharge rate of $4.2 \mathrm{~mm} / \mathrm{y}$. The second case was identical except for an assumed recharge rate of $0.9 \mathrm{~mm} / \mathrm{y}$. The third case was the new ILAW concrete vault with a recharge rate of $4.2 \mathrm{~mm} / \mathrm{y}$. A steadystate, unsaturated flow field was calculated and used to provide water contents and water fluxes used in each of the transient reactive transport simulations. For each of the three cases, the flux of Tc to the vadose zone was calculated across the lower boundary of the model, as described in Equation 3.8. Profiles of TCO; concentration, LAWABP1 dissolution rate, and pH are presented in order to explain the difference in flux predicted by each of the three cases.

\subsubsection{Unsaturated Flow Field Used in Waste Form Release Calculations}

Assuming steady-state flow with a constant recharge rate results in a constant water flux, equal to the recharge rate, throughout the entire depth of the profile. Water content, however, will vary with depth in the profile. Water content is a dimensionless variable defined as the volume of water per volume of porous or fractured media. The unique relationship between water flux and water content for each material is defined by the hydraulic parameters listed in Table 3.2. For the two RH trench simulations, water contents inside the glass layers are lower at a recharge rate of $0.9 \mathrm{~mm} / \mathrm{y}$ than at recharge rute of $4.2 \mathrm{~mm} / \mathrm{y}$ (Figure 4.1). In either case, water contents in the surrounding materials are two orders of magnitude higher than in the glass (Figure 4.1). For the vault simulation, the water contents in the glass (Figure 4.2) are similar to those oberved in the trench simulation at the sime recharge rate. Water contents in the vault filler are an order of magnitude higher, and water contents in the concrete and backfill are two orders of magnitude higher than in the glass. 


\section{DOE/ORP-2000-19, REV. 0 \\ Reference: DOE/ORP-2000-07, REV. 0}

\subsubsection{RH Trench Simulation with $4.2 \mathrm{~mm} / \mathrm{y}$ Recharge Rate}

The maximum flux of Tc to the vadose zone for the RH trench base case simulation is 8.4 $\mathrm{ppm} / \mathrm{y}$ at $20,000 \mathrm{y}$ (Figure 4.3). The $\mathrm{Tc}$ flux to the vadose zone is proportional to the $\mathrm{TcO}_{4}$; concentration at the lower boundary and the water flux rate (see Equation 3.7b). At early times the $\mathrm{TcO}_{4}$ concentrations (Figure 4.4) increase sharply in the glass layers. Glass dissolution, and low water contents in the glass layers (Figure 4.1), coupled with a low water flux rate, causes $\mathrm{TCO}_{4}$ concentrations to increase rapidly in the glass layers. In contrast, mass transport from the glass layers is required to buildup Tc concentrations in the backfill layers. . Therefore, concentrations $\mathrm{n}$ the backfill layers increase slowly as products of glass dissolution diffuse from the glass layers into the backfill layers, where dilution also occurs because of the much higher water content in the backfill layers compared with the glass layers. Predicted glass dissolution rates (Figure 4.5) increase with time in each of the glass layers, but are relatively similar for each layer.

For this and the following two simulations, it was conservatively assumed that glass dissolution was at the forward rate of reaction. In other words, buildup in the activities of species caused by glass dissolution, such as $\mathrm{AlO}_{2}^{-}$and $\mathrm{SiO}_{2}$ (aq), were not considered to decrease the glass dissolution rate. In this case, Equation 3.5 simplifies to

$$
k_{i}=\vec{k}_{\mathrm{H}^{2}}^{-\eta} e \frac{-E_{\mathrm{a}}}{\mathrm{RT}} .
$$

Iron corrosion product reactions were included in the simulations, but their only effect in the present simulations was to slightly alter the solution pH early in the simulations. The glass dissolution rate for these simulations is therefore proportional to the $\mathrm{pH}$ of the pore water in the glass fractures, as well as the surface area of the glass. The $\mathrm{pH}$ of pore water increases from a background value of 7 to a maximum value of 9.5 in the center of the groups of waste packages (Figure 4.6). Because the glass dissolution rate is relatively low, the surface area of the glass does not decrease noticeably by 20,000 years. The $\mathrm{pH}$ and $\mathrm{TCO}_{4}$ concentrations increase more rapidly in the glass layers early in the simulation, although by 20,000 years concentrations in all layers are relatively similar. This indicates that at early times, the $\mathrm{TcO}_{4}$ flux across the lower boundary is limited by the diffusion rate of $\mathrm{TCO}_{4}$ out of the glass layers.

\subsubsection{RH Trench Simulation with $0.9 \mathrm{~mm} / \mathrm{y}$ Recharge Rate}

The maximum flux of $\mathrm{Tc}$ to the vadose zone for a case where the recharge was lowered to $0.9 \mathrm{~mm} / \mathrm{y}$ is $0.98 \mathrm{ppm} / \mathrm{y}$ at $20,000 \mathrm{y}$ (Figure 4.3 ). This is 8.5 times lower than the maximum flux predicted by the $\mathrm{RH}$ trench simulation with a $4,2 \mathrm{~mm} / \mathrm{y}$ recharge rate. TCO; concentrations (Figure 4.7$)$ are higher in the glass layers at this lower recharge rate $(0.9 \mathrm{~mm} / \mathrm{y})$ because glase dissolution rates (Figure 4.8) are higher, and water contents in the glass layers are lower (Figure 4.1). Figher glass dissolution rates are expecthd in this case because the decrease in flow rate means less influx of low $\mathrm{pH}$ and low ionic strength fluid into the system, driving the $\mathrm{pH}$ higher (Figure 4.9) in the glass layers. TCO; concentrations with time at the lower boundary, however, 


\section{DOE/ORP-2000-19, REV. 0 \\ Reference: DOE/ORP-2000-07, REV. 0}

are lower than seen in the base case simulation. Although glass release rates are higher than for the base case, lower water contents in the glass layers result in lower rates of diffusion from the glass layers. This, coupled with a lower water flux, results in a lower flux to the vadose zone. Results from the previous PA (Mann 1998a), showed that a 10-fold decrease in recharge resulted in a 3-fold decrease in Tc flux to the vadose zone. However, in that simulation water content did not vary appropriately with the recharge rate.

\subsubsection{New ILAW Vault Simulation with $4.2 \mathrm{~mm} / \mathrm{y}$ Recharge Rate}

The maximum flux of $\mathrm{Tc}$ to the vadose zone for the new IIAW vault simulation is 11.8 $\mathrm{ppm} / \mathrm{y}$ at approximately 5,500 y (Figure 4.3). This flux is $40 \%$ higher than for the RH trench base case simulation (Figure 4.3). The glass packages are more closely packed in this simulation than in the trench simulation. $\mathrm{TcO}_{4}$ concentrations (Figure 4.10) increase rapidly and remain at a relatively constant value until 20,000 years. Predicted glass dissolution rates (Figure 4.11) are highest early in the simulation and decrease gradually as the surface area of the glass slowly decreases. Because the waste packages are more closely packed, the dissolution rate is higher than in the RH trench simulations. This is because the $\mathrm{pH}$ inside the waste packages is not impacted as much as in the RH trench simulations by mass transport and dilution from the higher water contents in the intervening layers (Figure 4.12). Because the packages are more closely packed, a greater area of the glass is at or near the maximum $\mathrm{pH}$ than in the RH trench simulations. The early time spike in glass dissolution near the bottom of the vault (Figure 4.11) is caused by higher $\mathrm{pH}$ (Figure 4.12) in that region due to concrete dissolution. At later times, the $\mathrm{pH}$ is dominated by the release of glass constituents.

\subsubsection{Discussion of Waste Form Release Calculations}

These simulations are thought to be conservative because, when 2-D flow is modeled, the resulting glass water contents are lower than for the 1-D calculations, which would result in a lower Te flux to the vadose zone. Also, in the laboratory tests performed on LAWABP1, when $\mathrm{SiO}_{3}(\mathrm{aq})$ and $\mathrm{AlO}_{2}$ concentrations are high, the glass dissolution rate is considerably lower. However, for both of these issues, the results presented here are conservative (i.e., they overestimate the impact). Another issue is the fict that we have assumed that the hydraulic properties of the glass remain constant with time. Over time, as the glass dissolves and secondary minerals (mostly clays) precipitate, the hydraulic properties of the waste form may change from that of a fractured glass to that of porous clay. This proceas may cause a decrease in the hydraulic conductivity. However, because of the lower density of the secondary minerals with respect to the parent glass, a net expansive pressure will be exerted (Nozali 2000), which could increase crack widths in the glass and so increase hydraulic conductivity. Experiments are being undertaken this fiscal year to determine the impact of glass corrosion on the hydraulic properties of fractured glass.

Release rates for other radioactive species of interest have not been calculated. The previous PA (Mann 1998a) indicated that maxidum release rates for total Pu and ${ }^{129} 1$ would be similar to those predicted for ${ }^{9} \mathrm{TC}$. In addition, release rates for total $U$ and ${ }^{7}$ Se would be $28 \%$ and $56 \%$ higher, respectively. These rate changes were included in the results summarized in section 4.5. The release rates for other radionudides and hazardous chemicals are assumed to be equal to the release rate for ${ }^{99} \mathrm{Tc}$.

$$
\text { A- } 68
$$


DOE/ORP-20CO-19, REV. 0

Reference: DOE/ORP-2000-07, REV. 0

Figure 4.1 Steady-state Moisture Content for the RH Trench 1-D Waste Form Release Model at Different Recharge Rates (horizontal dotted lines represent boundaries between material zones and material names shown along the right axis)

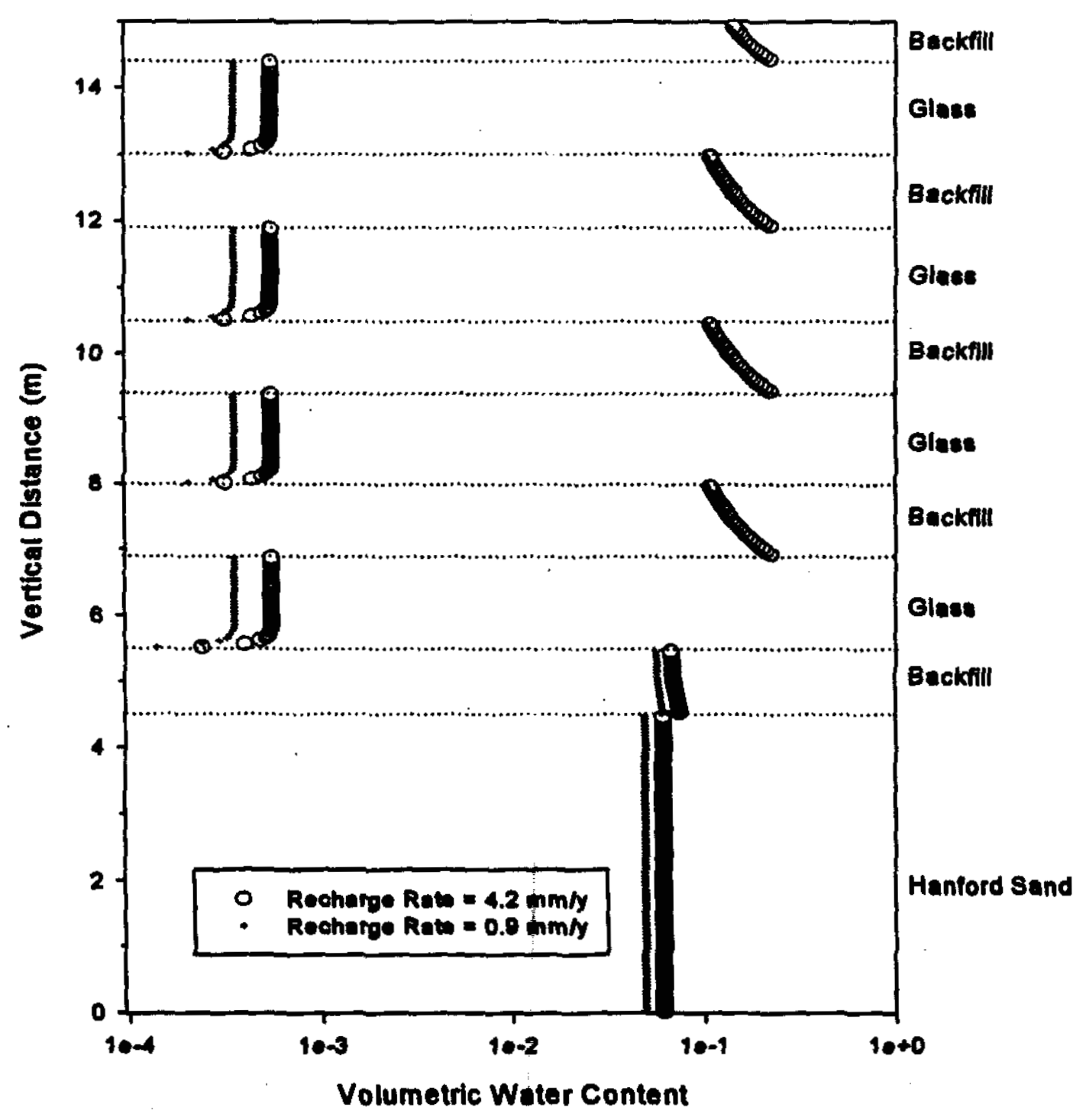


Figure 4.2 Calculated Steady-state Moisture Content for the Vault 1-D Waste Form Release Model (horizontal dotted lines represent boundaries between material zones and material names are shown along right axis)

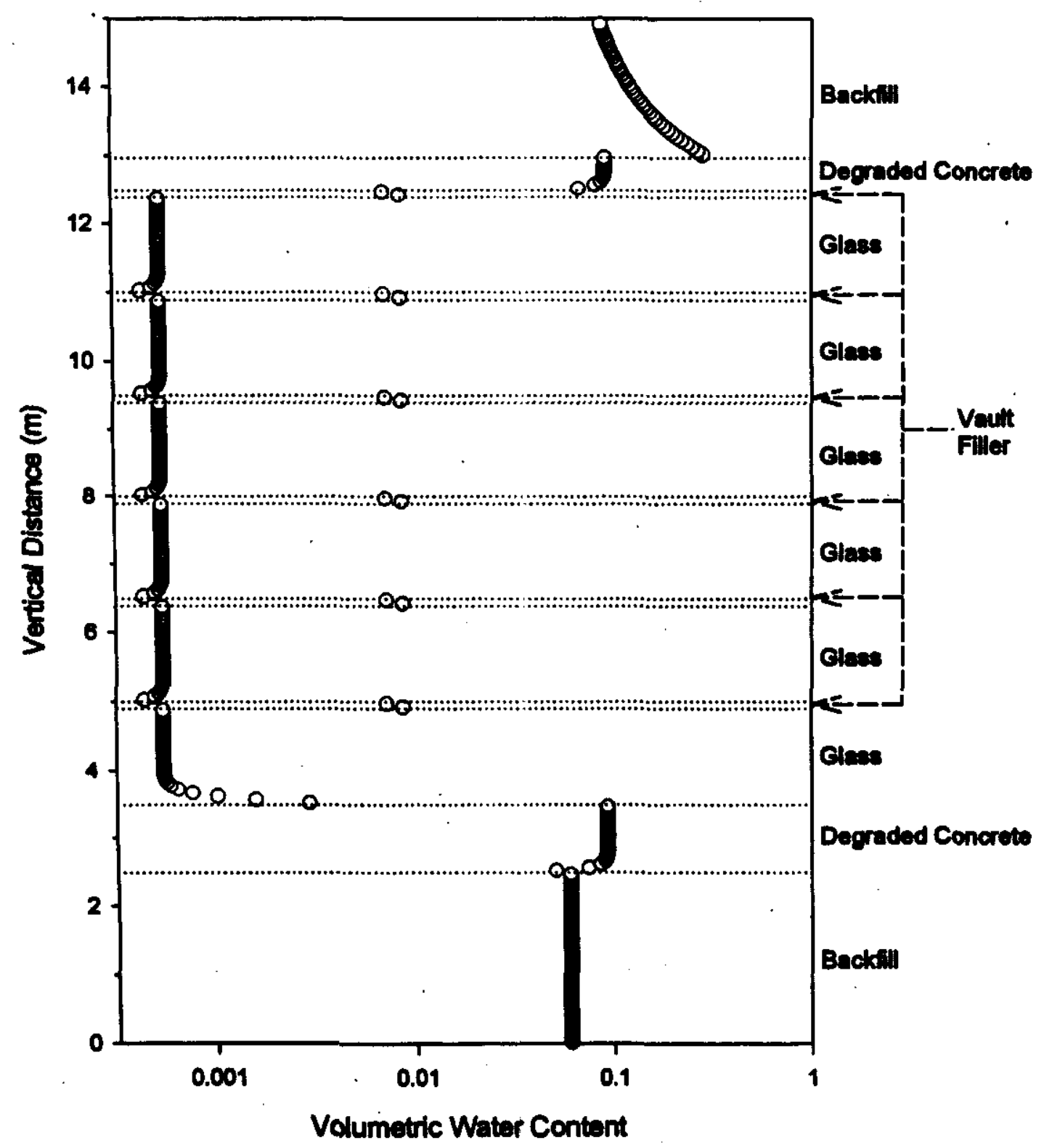




\section{DOE/ORP-2000-19, REV. 0 \\ Befferen: DOE/ORP-2000-07, REV. 0}

Figure 4.3 Technetium Flux Across Bottom Boundary of Model, Normalized to Amount of Technetium Originally in Waste Form

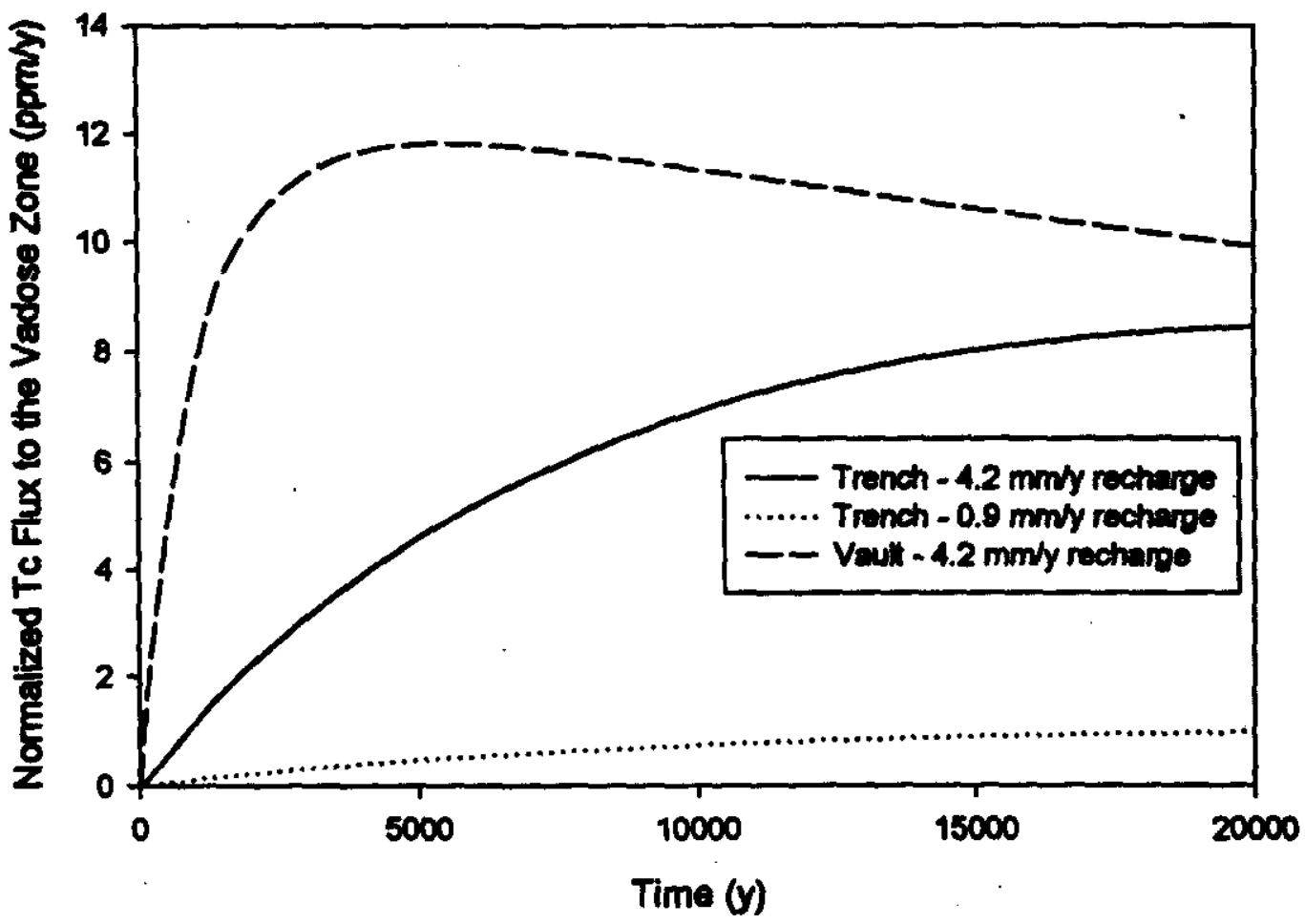


DOE/ORP-2000-19, REV. 0

Beferens: DOE/ORP-2000-07, REV. 0

Figure 4.4 $\mathrm{TCO}_{4}^{-}$Concentrations for RH Trench Simulation With Recharge Rate of $4.2 \mathrm{~mm} / \mathrm{y}$ (Horizontal Dotted Lines Represent Boundaries Between Material Zones And Material Names Are Shown Along Right Axis)

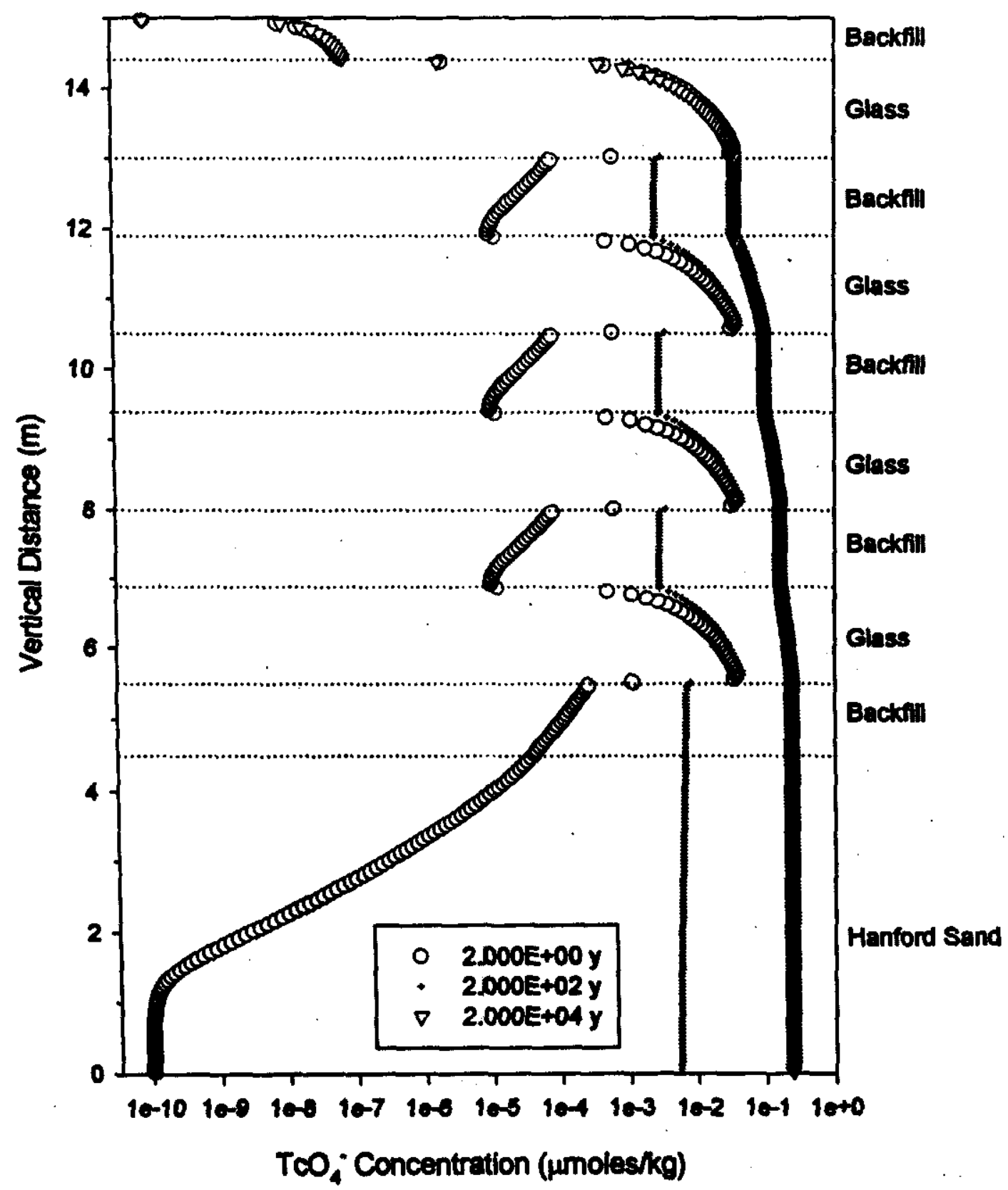


Figure 4.5 LAWABPI Dissolution Rate for RH Trench Simulation With Recharge Rate of 4.2 $\mathrm{mm} / \mathrm{y}$ (Horizontal Dotted Lines Represent Boundaries Between Material Zones And Material Names Are Shown Along Right Axis)

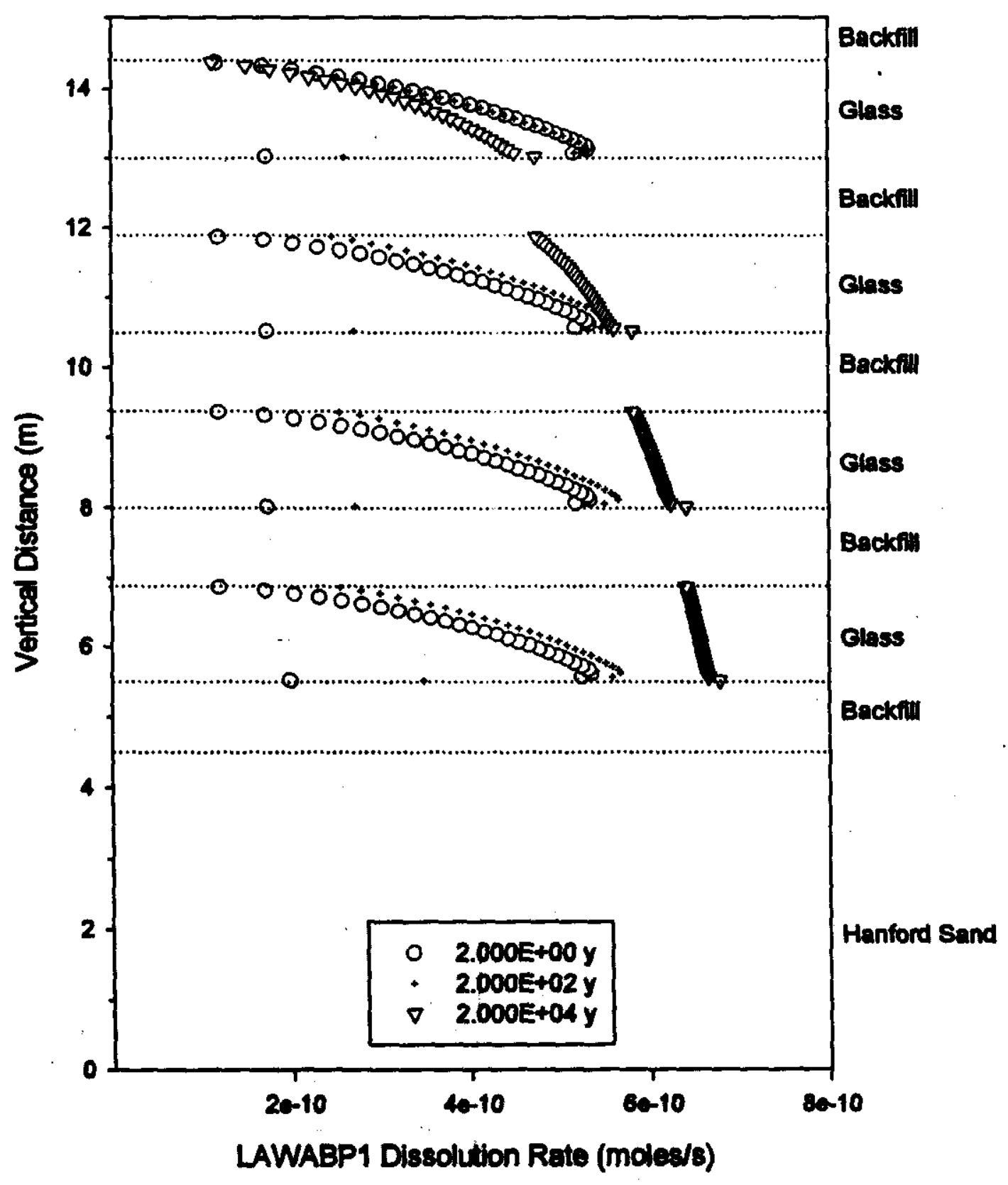


DOE/ORP-2000-19, REV. 0

Befereng: DOE/ORP-2000-07, REV. 0

Figure4.6 pH for RH Trench Simulation With Recharge Rate of $4.2 \mathrm{~mm} / \mathrm{y}$ (Horizontal Dotted Lines Represent Boundaries Between Material Zones And Material Names Are Shown Along Right Axis)

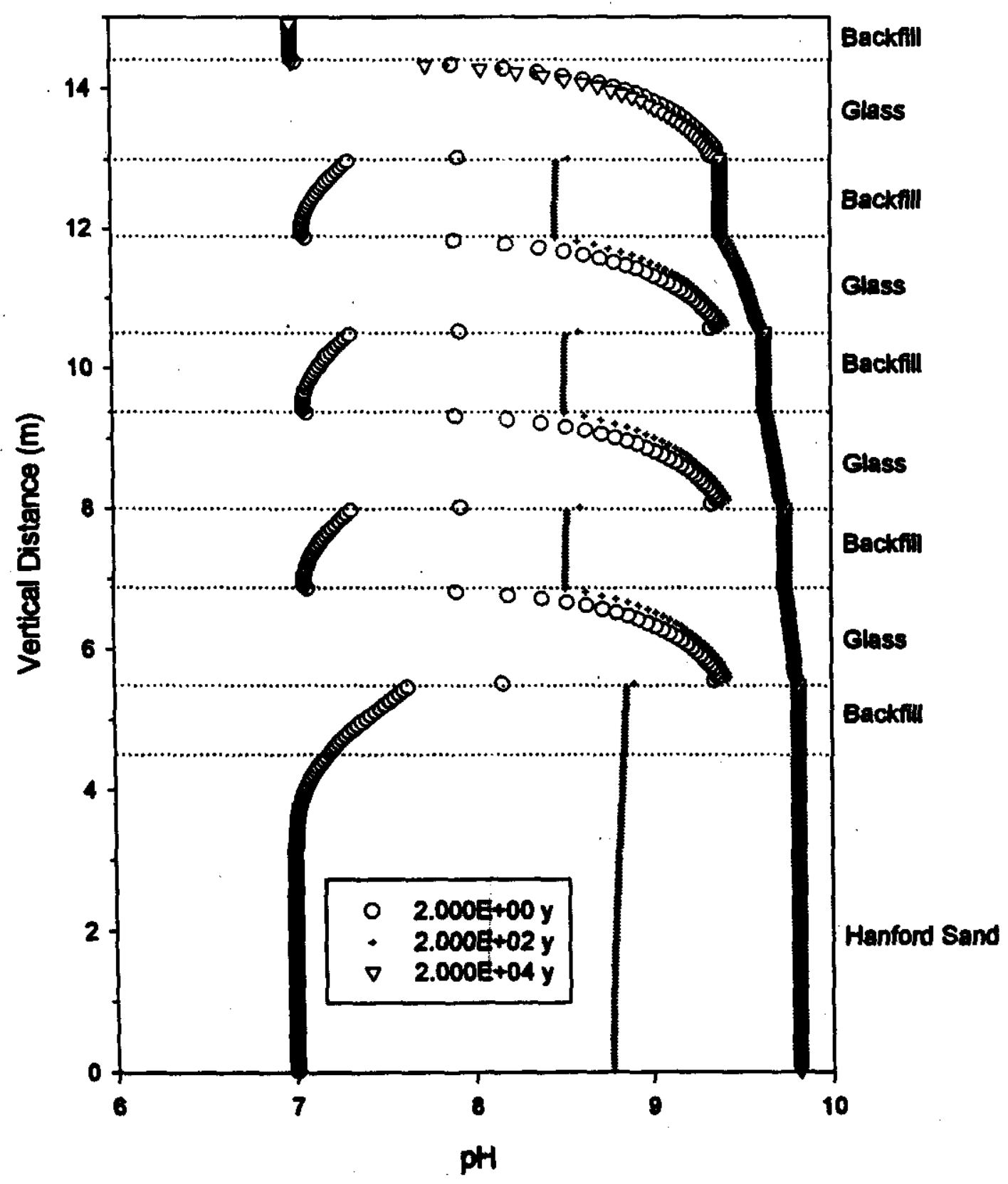


Figure 4.7 $\mathrm{TcO}_{4}$ Concentrations for RH Trench Simulation With Recharge Rate of $0.9 \mathrm{~mm} / \mathrm{y}$ (Horizontal Dotted Lines Represent Boundaries Between Material Zones And Material Names Are Shown Along Right Axis)

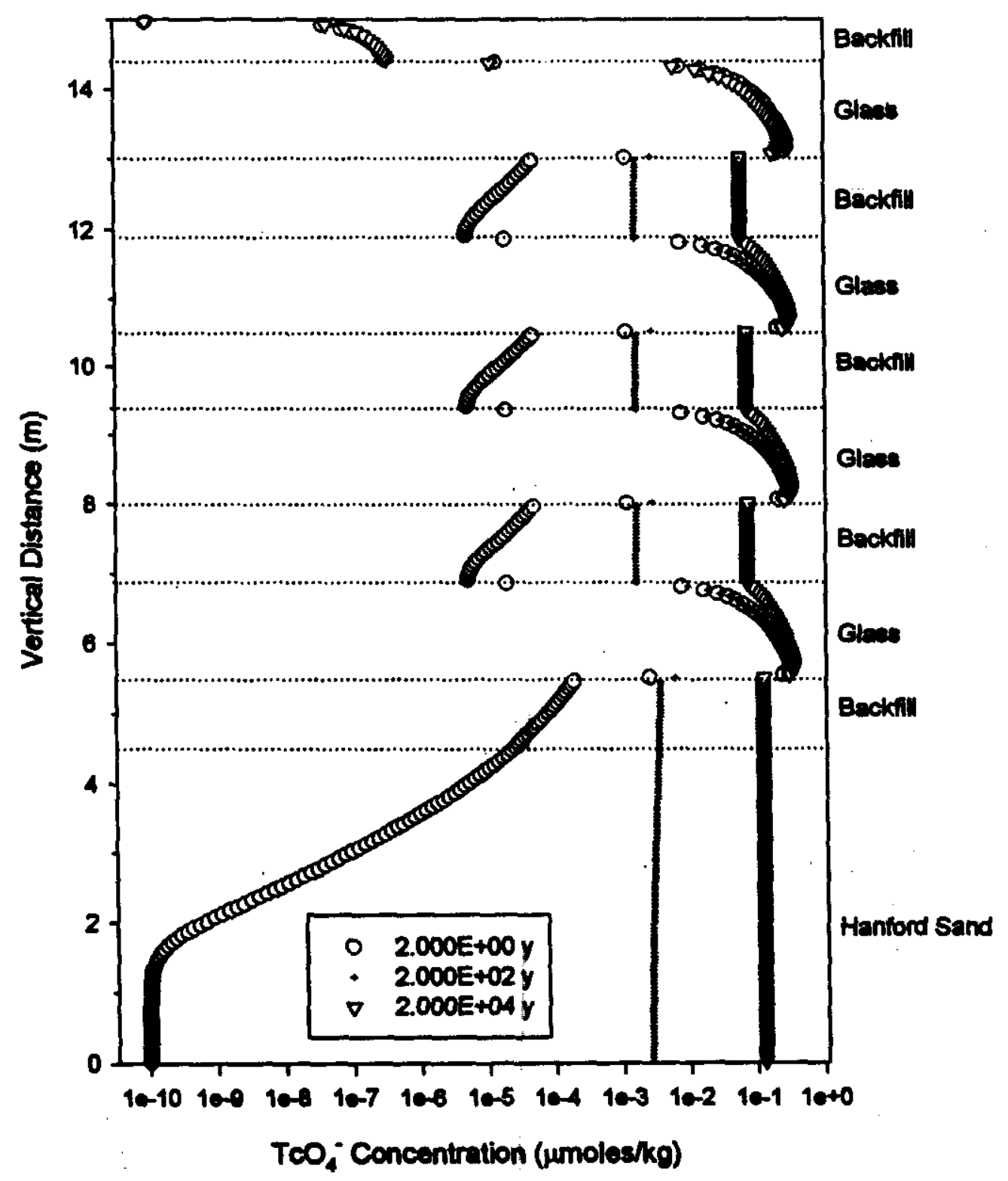


Figure 4.8 LAWABP1 Dissolution Rate for RH Trench Simulation With Recharge Rate of $0.9 \mathrm{~mm} / \mathrm{y}$ (Horizontal Dotted Lines Represent Boundaries Between Material Zones And Material Names Are Shown Along Right Axis)

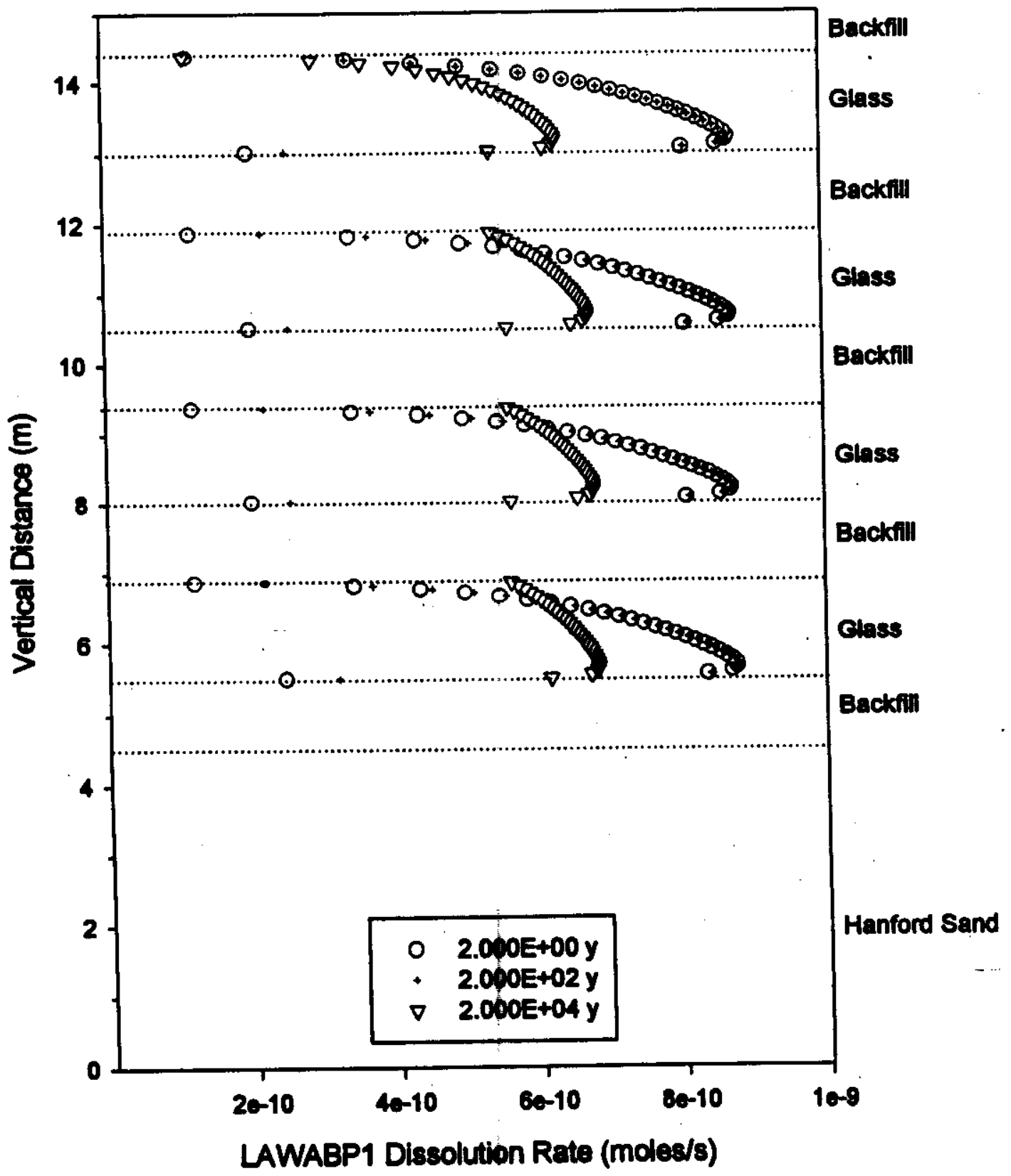


Figure4.9 pH for RH Trench Simulation With Recharge Rate of $0.9 \mathrm{~mm} / \mathrm{y}$ (Horizontal Dotted Lines Represent Boundaries Between Material Zones And Material Names Are Shown Along Right Axis)

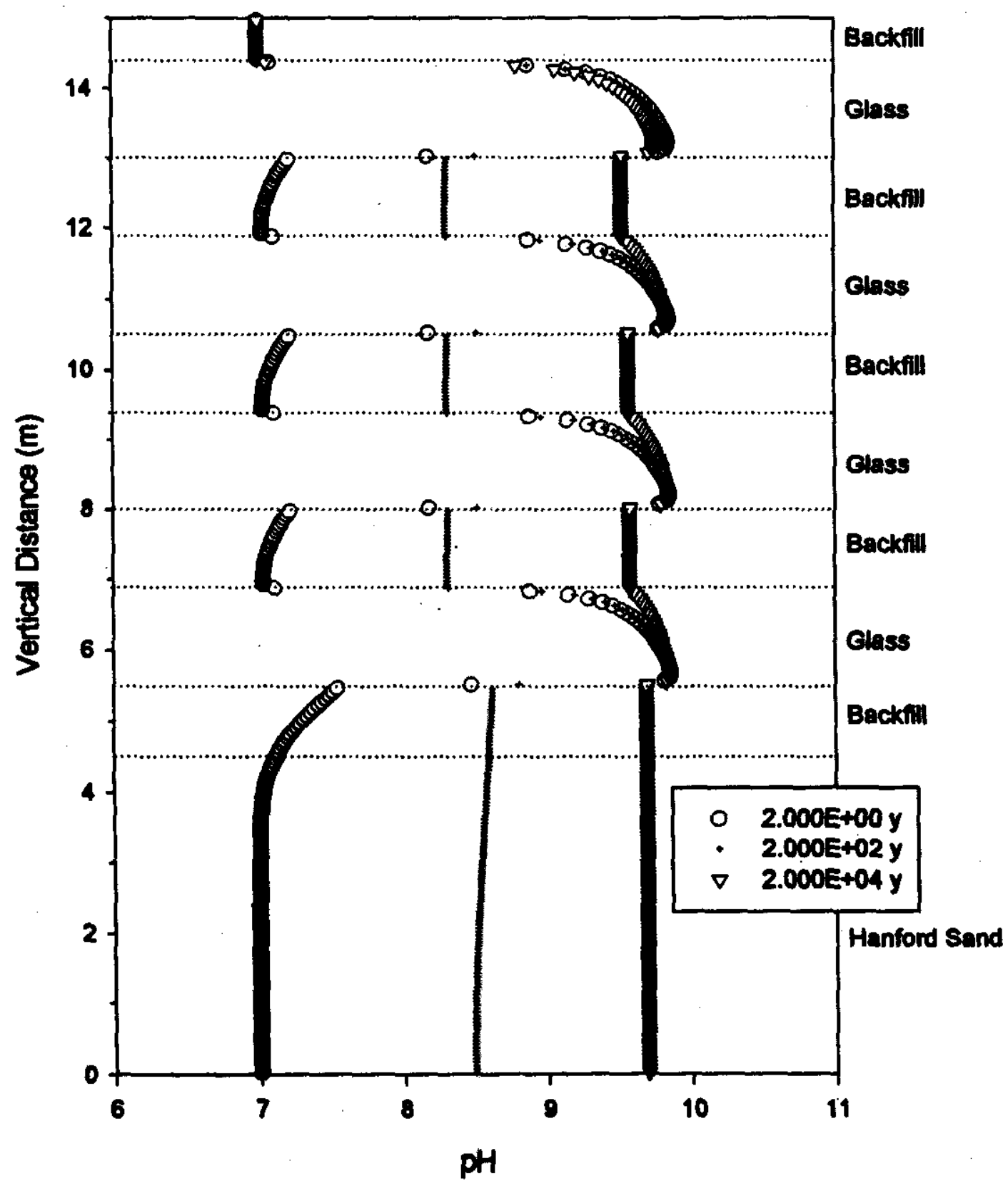


Figure 4.10 $\mathrm{TcO}_{4}$ Concentrations for New Il AW Vault Simulation With Recharge Rate of 4.2 $\mathrm{mm} / \mathrm{y}$ (Horizontal Dotted Lines Represent Boundaries Between Material Zones And Material Names Are Shown Along Right Axis)

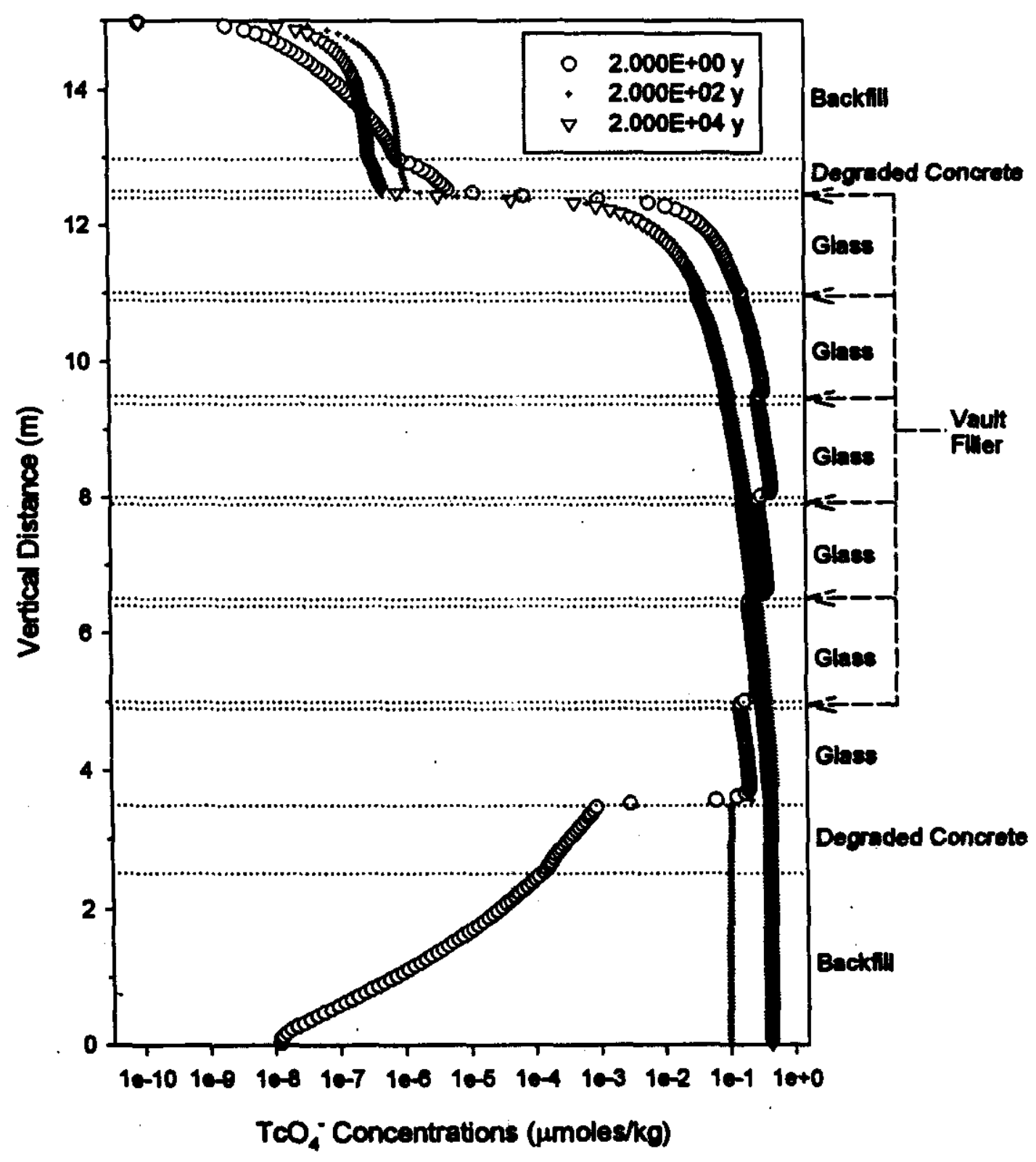




\section{DOE/ORP-2000-19, REV. 0 \\ Reference: DOE/ORP-2000-07, REV. 0}

Figure 4.11 LAWABP1 Dissolution Rate For New ILAW Vault Simulation With Recharge Rate of $4.2 \mathrm{~mm} / \mathrm{y}$ (Horizontal Dotted Lines Represent Boundaries Between Material Zones And Material Names Are Shown Along Right Axis)

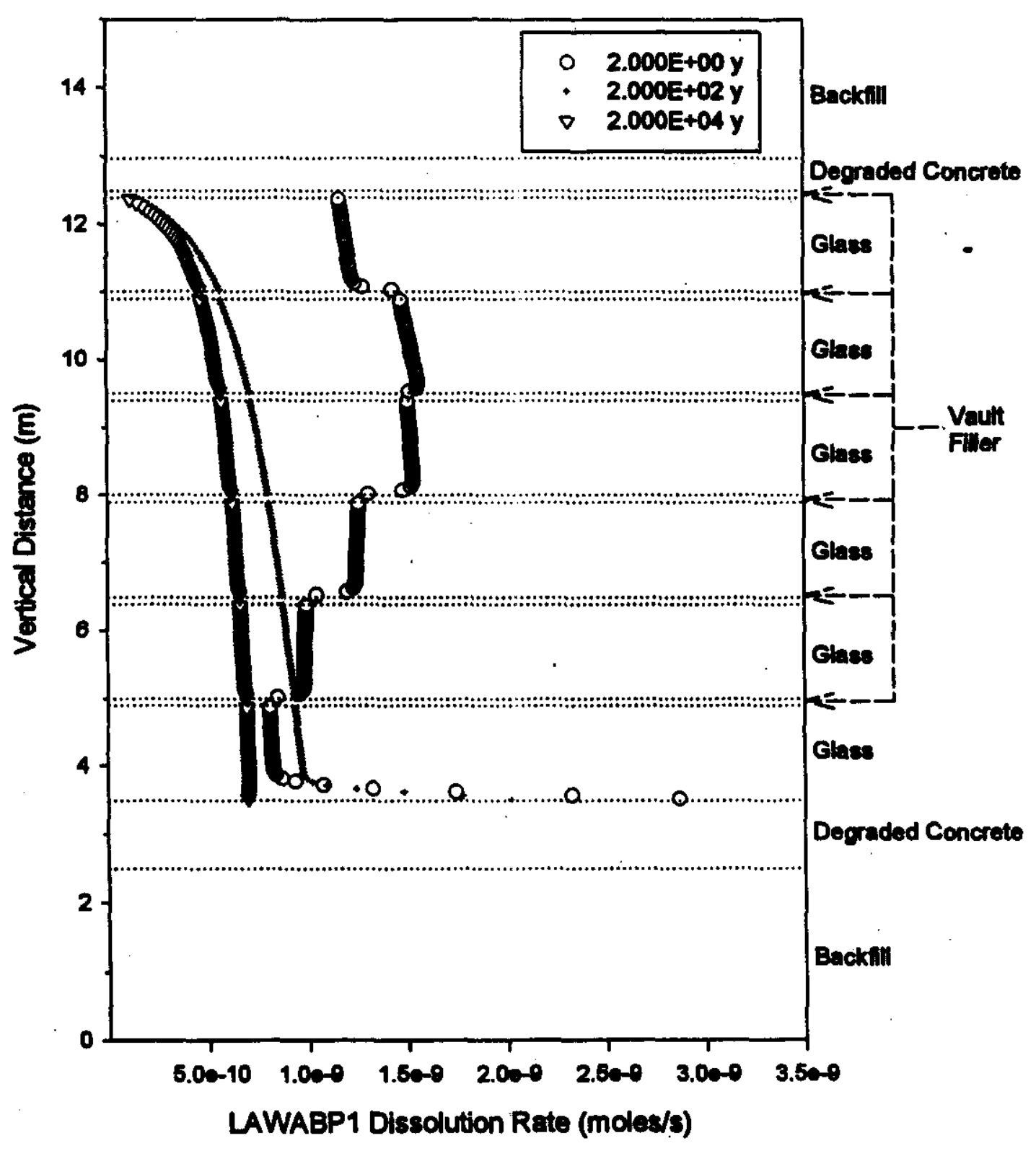


DOE/ORP-2000-19; REV. 0

Beferenes: DOE/ORP-2000-07, REV. 0

Figure 4.12 pH for New IIAW Vault Simulation With Recharge Rate of $4.2 \mathrm{~mm} / \mathrm{y}$ (Horizontal Dotted Lines Represent Boundaries Between Material Zones And Material Names Are Shown Along Right Axis)

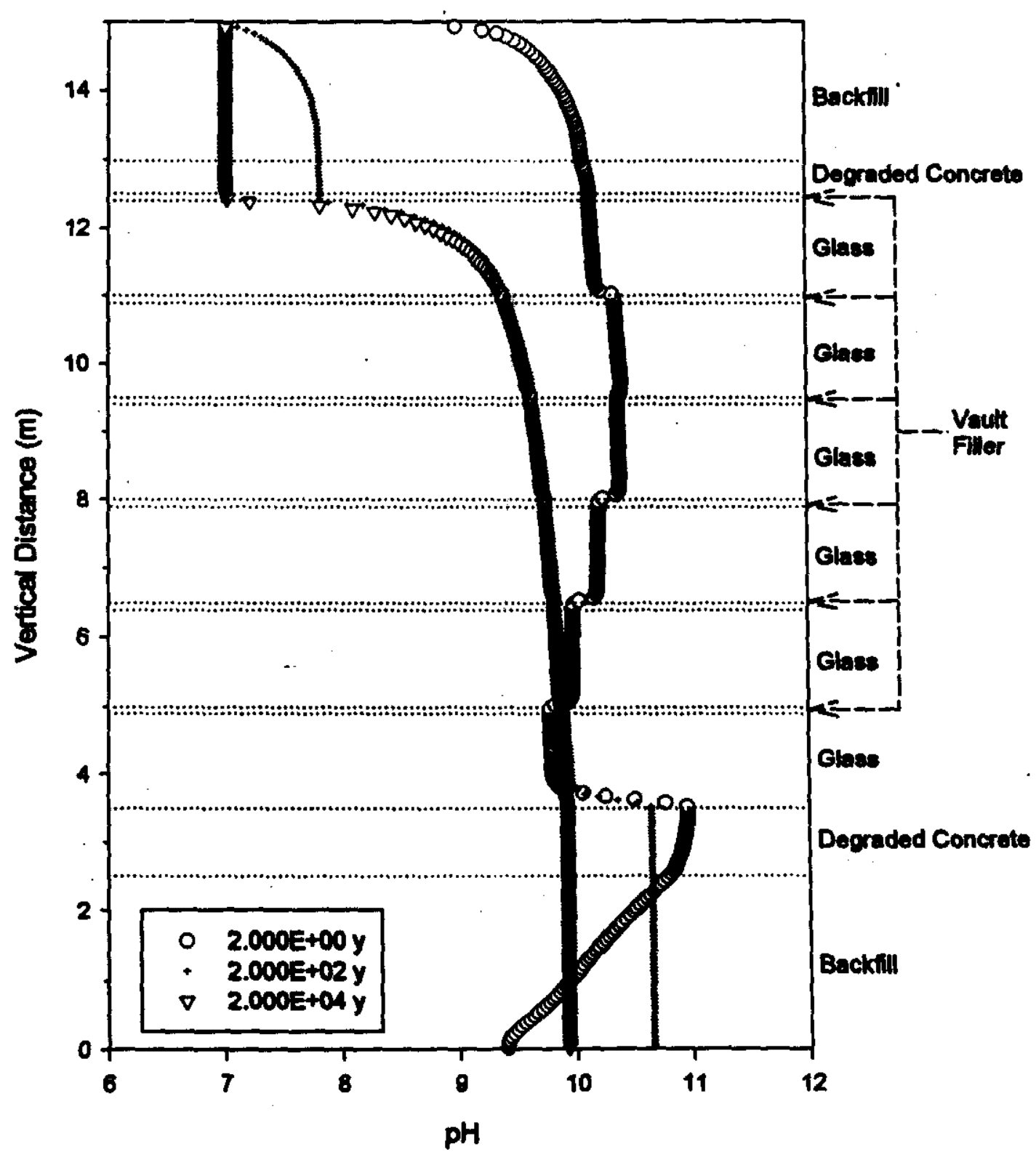




\subsection{Far-Field Results}

\subsubsection{Contaminant Transport through the Far Field}

Input volumetric fluid flux and mass flux for ${ }^{99} \mathrm{Tc}$ to the far field was derived from the output from the one dimensional waste form model (Figure 3.6) and the waste package distribution shown in Figure 2.4 for the RH trench. Volumetric fluid flux and mass flux at discrete time steps were used to generate a time history of fluid and contaminant fluxes for each node at the upper boundary (depth $=0.0 \mathrm{~m}$ in Figures 3.6 and 3.7). Calculated arrival times and concentration of contaminant species at the water table after migration through the vadose zone are presented in this section. The migration time and concentration will dictate the timing and level of contamination entering the groundwater. The mass of contaminant leaving the vadose zone and the flux of groundwater in an upper mixing zone will dictate the water quality that eventually impacts man in the various exposure scenarios investigated in this report.

The steady state hydraulic conditions for the vadose zone calculations had the effective water flux in both the Hanford Sand and the Hanford gravel sequences equal to the recharge for the case being run. For a recharge rate of $4.2 \mathrm{~mm} / \mathrm{y}$ the resulting moisture in the Hanford sand sequence was approximately $6 \%$ moisture content everywhere. Similarly the resulting moisture content in the Hanford Gravel sequence was 5\% everywhere.

Figure 4.13 shows the contaminant release fraction into the aquifer as a function of time after facility closure for the $\mathrm{RH}$ trench. The concentration beneath the $\mathrm{RH}$ trench for the contaminant species with $\mathrm{K}_{d}=0 \mathrm{~mL} / \mathrm{g}$ shows the first breakthrough occurs after approximately $500 \mathrm{y}$ after facility closure (see Figure 4.14). Breakthrough is defined as the onset of contaminants reaching the aquifer (at a rate of $0.001 \mathrm{Ci} / \mathrm{y} / \mathrm{Ci}$ ) after their introduction at the top of the vadose zone. The leading edge of contaminant plume migrates a distance of $93 \mathrm{~m}$ within the vadose zone in approximately 500 years (breakthrough). The bulk of the contaminant is still well within the vadose zone when the edge of the contaminant plume enters the groundwater. The mean transit time for the contaminants through the vadose zone is approximately 1,200 years. The mean travel time is defined as the time interval for the contaminant transport rate into the aquifer to equal the initial contaminant source rate at the top of the vadose zone.

The mean transit time through the vadose zone can be estimated. Given the effective water flux and moisture content in the two regions in the vadose zone model, the travel time for the contaminants can be estimated using the equation

$T=\left(D_{1} \times \theta_{g}\right) / R+\left(D_{z} \times \theta_{2}\right) / R$

where

$D_{1}=$ Distance in the vadose zone between the facility bottom and gravel sequence (55m) $D_{k}=$ Distance in the vadose zone between the gravel sequence and the aquifer (38m) $R=$ recharge rate (base case $=4.2 \mathrm{~mm} / \mathrm{y}$ )

$\theta_{48}=$ moisture content in the vadose zone (sand $=0.05$, gravel $=0.06$ ). 
From equation 4.1 and for the base case recharge rate, the travel time in the vadose zone is estimated to be approximately 1200 years. The longitudinal dispersion associated with the transport can shorten the time to the aquifer.

\subsubsection{Geochemical $\left(\mathrm{K}_{\mathrm{d}}\right)$ Impact on Far Field Contaminant Transport}

Figure 4.13 shows the integrated contaminant flux into the aquifer as a function of time and for two $\mathrm{K}_{d}$ 's out to $20,000 \mathrm{y}$ after facility closure. The specific calculation is for the base analysis case for the RH trench. The flux is normalized to the quantity of contaminant in the waste form at time zero. The concentration into the aquifer increases with increasing time after a residence time associated with the transport of the contaminant through the vadose zone. This increase is at approximately the same rate as the release from the waste form (see Figure 4.3). The delay in the travel time due to the transport through the vadose zone is approximately 1,200 years. For species with a similar inventory but a $\mathrm{K}_{d}$ of 0.6 , breakthrough is at approximately 10,000 years and the contaminant release rate into the aquifer does not reach the release rate from the waste form after $20,000 \mathrm{y}$. For other higher values of $\mathrm{K}_{d}\left(\mathrm{~K}_{d} \geq 4 \mathrm{~mL} / \mathrm{g}\right)$, there is no significant release of contaminant into the aquifer within the 20,000 year simulation timeframe.

Figure 4.13 Normalized Contaminant Flux to the Aquifer for the RH Trench and a Recharge of $4.2 \mathrm{~mm} / \mathrm{y}$ (Linear Scale for Release Fraction)

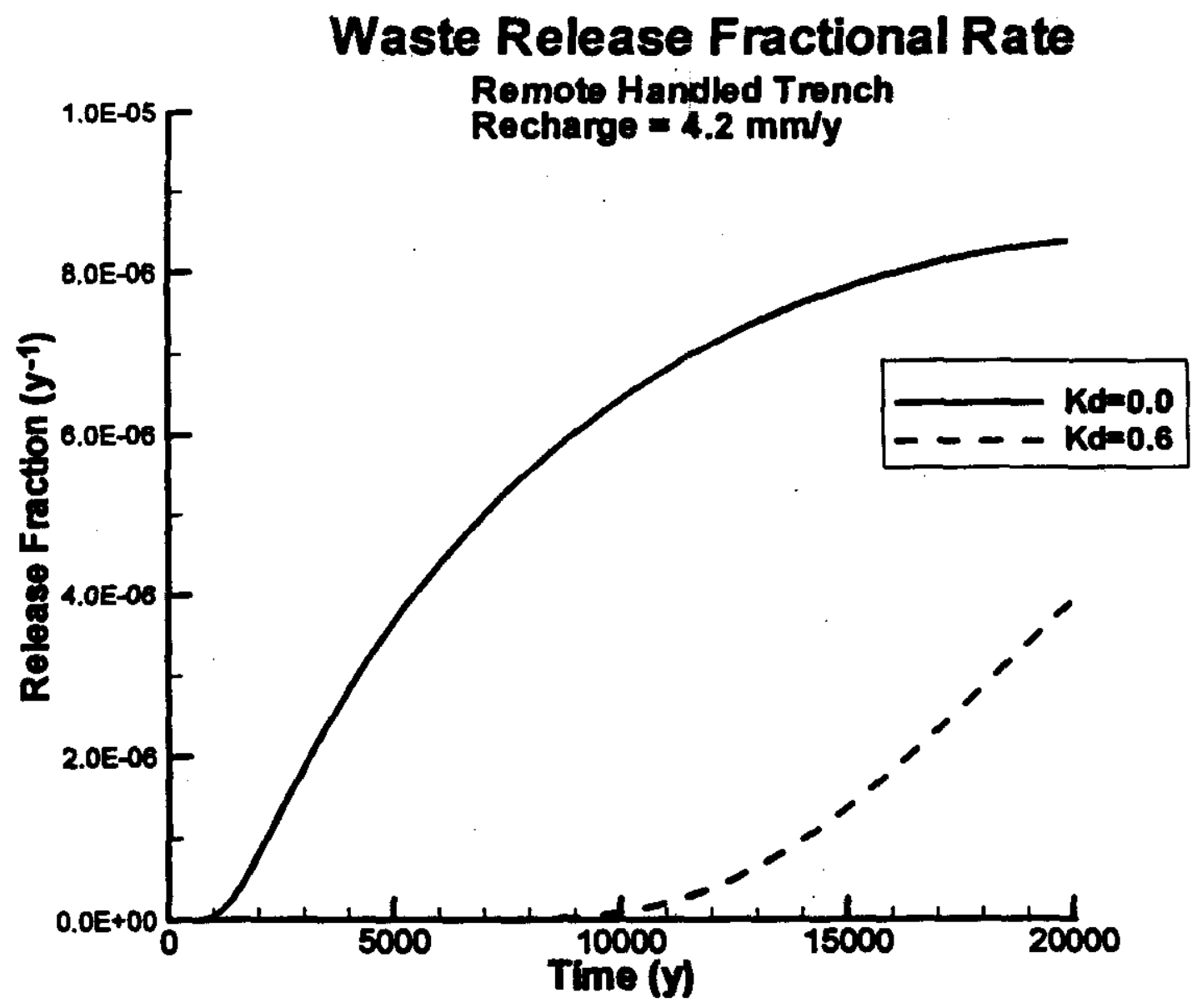




\subsubsection{Recharge Impacts on Far Field Contaminant Transport}

A second RH trench simulation assumes a recharge above the waste form of $0.9 \mathrm{~mm} / \mathrm{y}$ rather than $4.2 \mathrm{~mm} / \mathrm{y}$ used in the base case. The results from the far field calculations for both recharge rates are shown in Figure 4.14. Figure 4.14 uses a logarithmic scale for the $y$-axis to more easily compare the impacts due to a change in recharge. The first significant increase in concentration is about 6,000 years for the $0.9 \mathrm{~mm} / \mathrm{y}$ recharge calculation. For the base analysis case, the concentration to the aquifer starts to become significant after only 1,200 years. This difference is due to the different transport times through the vadose zone associated with the different recharge rates. Additionally, the concentration of contaminant at 20,000 years after facility closure for the $0.9 \mathrm{~mm} / \mathrm{y}$ recharge case is factor of 10 less than for the $4.2 \mathrm{~mm} / \mathrm{y}$ recharge case. This result is consistent with the decrease noted for the waste form calculations for the base case and the reduced recharge case (see Figure 4.3). For the lower $\mathrm{K}_{\mathrm{d}}$ of $0.6 \mathrm{~mL} / \mathrm{g}$ and a recharge of $0.9 \mathrm{~mm} / \mathrm{y}$, there is no significant contaminant flux into the aquifer at 20,000 years.

Figure 4.14 Effect of Recharge Rate on the Normalized Contaminant Flux to the Aquifer for the

RH Trench (Logarithmic Scale for Release Fraction)

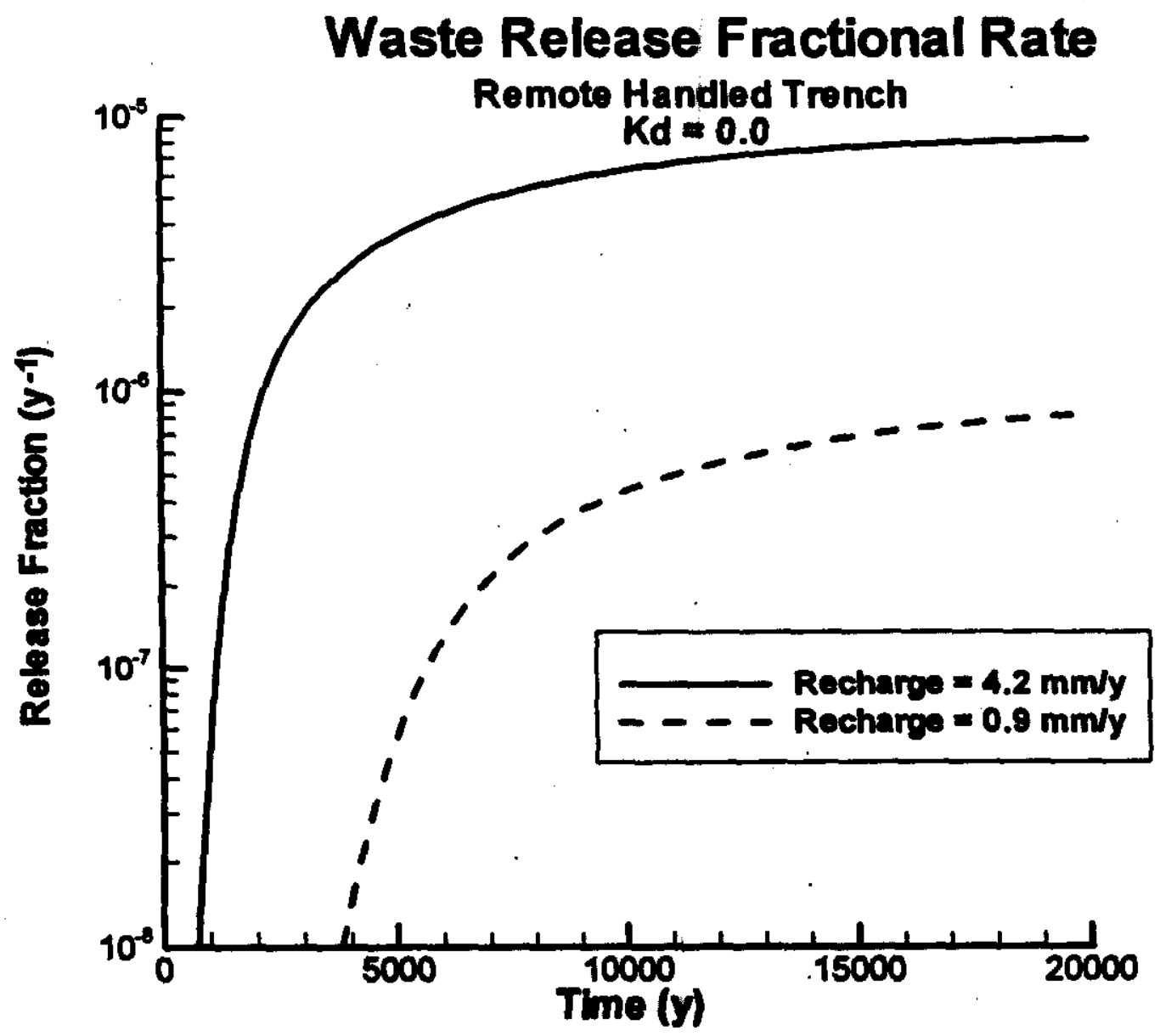


DOE/ORP-2000-19; REV. 0

Reference: DOE/ORP-2000-07, REV. 0

\subsubsection{Concrete Vault Results}

For the case of the ILAW vault design, the first arrival time for the conservative species at groundwater is again approximately 1,000 years after facility closure. As in the RH trench calculations, the concentration into the aquifer increases with increasing time after a residence time associated with the transport of the contaminant through the vadose zone. This linear increase is consistent with the linear increase of the release of contaminants from the waste form (see Figure 4.3). For the case where $K_{d}$. is 0.6 , the first significant increase occurs at approximately 10,000 years and does not peak within the 20,000 years time frame. The normalized concentration to the aquifer for the vault is shown to be about a factor of 8 times greater than the normalized concentration to the aquifer beneath the trench for times greater than 1000 years. This result is consistent with the difference in release rates noted for the waste form calculations (see Figure 4.3).

\subsubsection{Pulse Source Results}

The final sensitivity case models the effect of simulating instantaneous release of contaminents, rather than over a long period of time. Such a situation more closely corresponds to contamination on the surface of a canister, than to the bulk release. The simulation considers a single contaminant pulse over a 10 meter long interval at the bottom of the trench for the RH trench geometry. A one-curie source was evenly distributed along the ten meter surface for a total duration of one year. The contaminant source was then discontinued and the pulse was allowed to migrate through the vadose zone to groundwater. The software code VAMBDF (Huyakon and Panday 1999) was usod to calculate the transport through the vadose zone. Fluid flux to the system was consistent with the applied flux used for the base case $(4.2 \mathrm{~mm} / \mathrm{y})$. The results of this simulation (see Figure 4.15) show that the contaminant breakthrough occurs in about 500 years and reaches a peak value $\left(1.03 \times 10^{-3} \mathrm{Ci} / \mathrm{y} / \mathrm{Ci}\right)$ in about 1,300 yoars.

Contamination in groundwater has declined back to zero after about 5,000 years have elapsed. Note also that the calculation for $K_{d}=0.6$ contaminant species shows a peak value $\left(1.06 \times 10^{-1}\right.$ $\mathrm{Ci} / \mathrm{y} / \mathrm{Ci}$ ) after approximately 16,000 years. 
Figure 4.15 Release Rate from a 1 Curie Source for One Year from the RH Trench

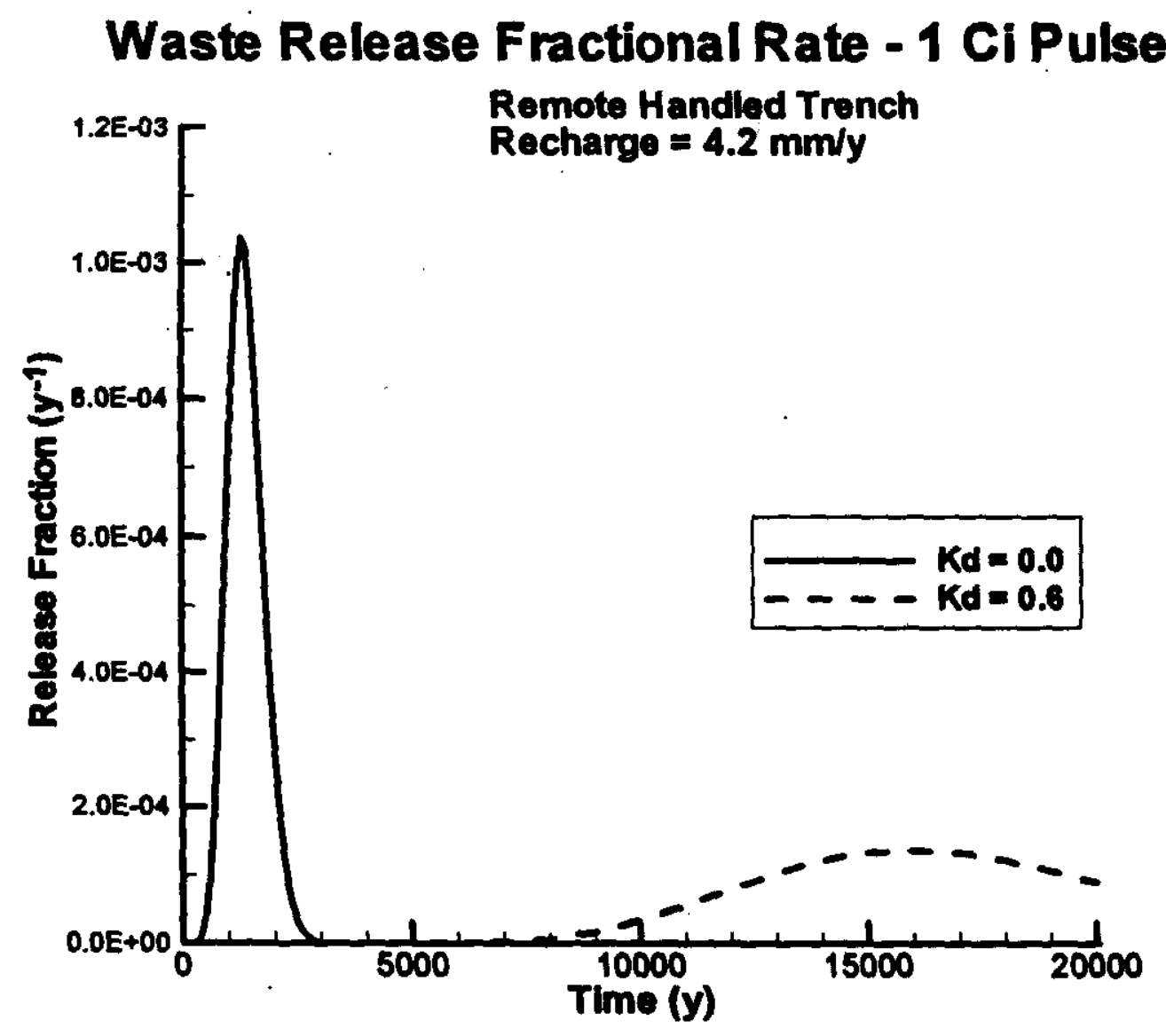

\subsection{Groundwater Results}

\subsubsection{Simulated Results at $100 \mathrm{~m}$. Downgradient Well}

Transport model reaults provided for the remoto-handled trench concept were based on local-scale flow conditions depicted in Figure 4.16. These conditions were developed based on boundary conditions provided by the steady-state simulation of post-Hanford flow conditions performed with the site-wide model. Ground vater moves across the ILAW site in a southeasterly direction before exiting the local-scale model in the southeast corner of the model.

The results are expressed in terms of well intercept factors (WIFs) which relate the contaminant concentration in groundwater to the vadose zone contaminant flux. WIFs were calculated at a distance of 100 meters downgradient from the facility as well as at an approximate distance of $1,000 \mathrm{~m}$ downgradient of the disposal facility boundaries. The WIF factors for $4.2 \mathrm{~mm} / \mathrm{y}$ and other assumed infiltration rates at this location are summarized in Table 4.1. The calculation assume the source is introduced from the vadose zone into the aquifer as a step function starting at time $t=0$. 
Table 4.1 Well Intercept Factors at $100 \mathrm{~m}$ and $1000 \mathrm{~m}$ for the Remote Handled Trench Disposal Concept Using Different Infiltration Rates

\begin{tabular}{|l|l|l|l|l|l|}
\hline & \multicolumn{5}{|c|}{ Infiltration rates (mm/y) } \\
\hline Well Locations & 0.1 & 0.9 & 1.0 & 4.2 & 5.0 \\
\hline $100 \mathrm{~m}$ & $4.2 \times 10^{-5}$ & $3.8 \times 10^{-1}$ & $4.2 \times 10^{-3}$ & $1.8 \times 10^{-3}$ & $2.1 \times 10^{-3}$ \\
\hline $1000 \mathrm{~m}$ & $2.3 \times 10^{-3}$ & $2.1 \times 10^{-1}$ & $2.3 \times 10^{-4}$ & $9.7 \times 10^{-4}$ & $1.2 \times 10^{-3}$ \\
\hline
\end{tabular}

Figure 4.16 Distribution of Hydraulic Head in Unconfined Aquifer in Local-Scale Model

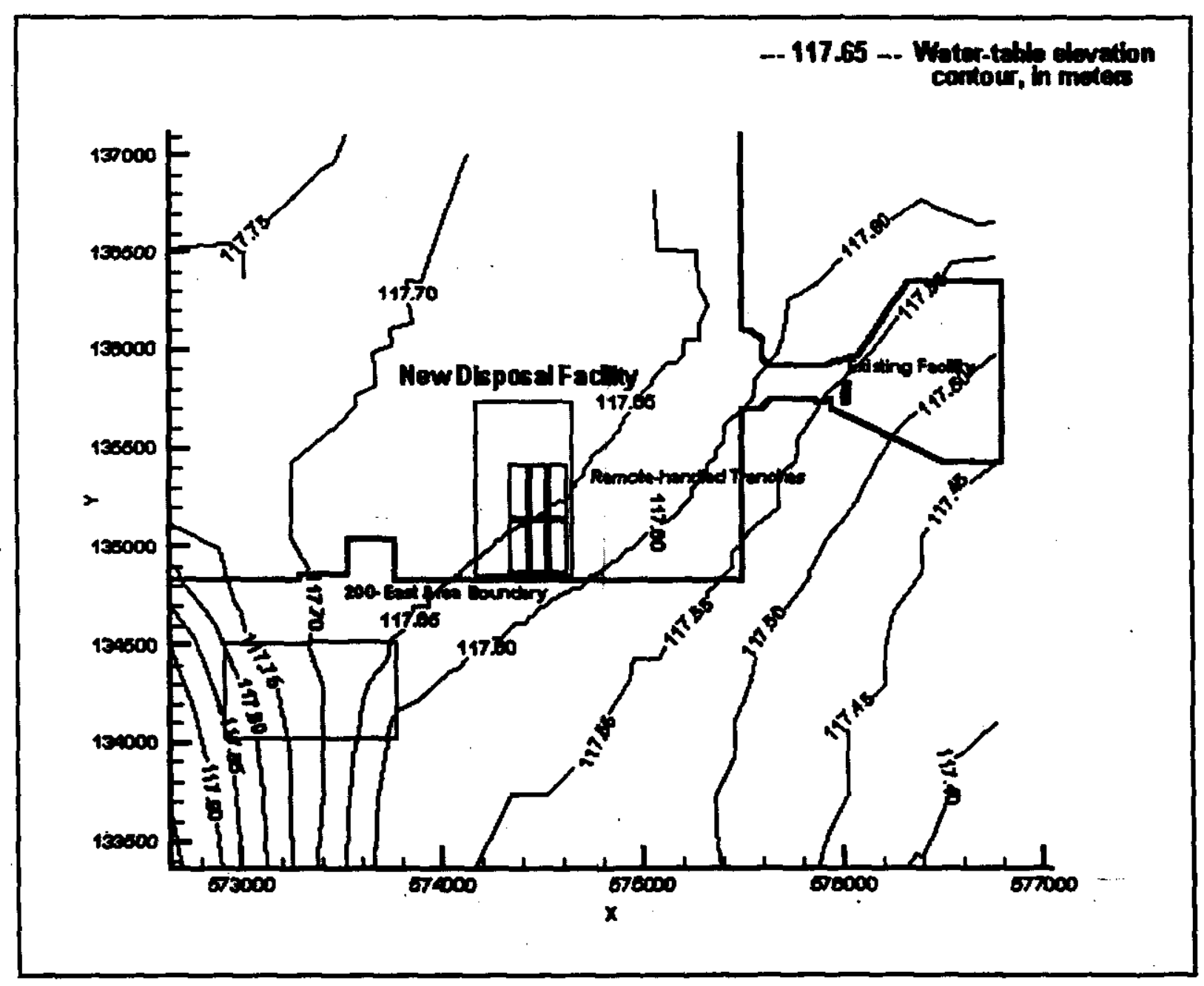


Figure 4.17 Areal Distribution of Contaminant Plume Resulting the Remote-Handled Trench Concept

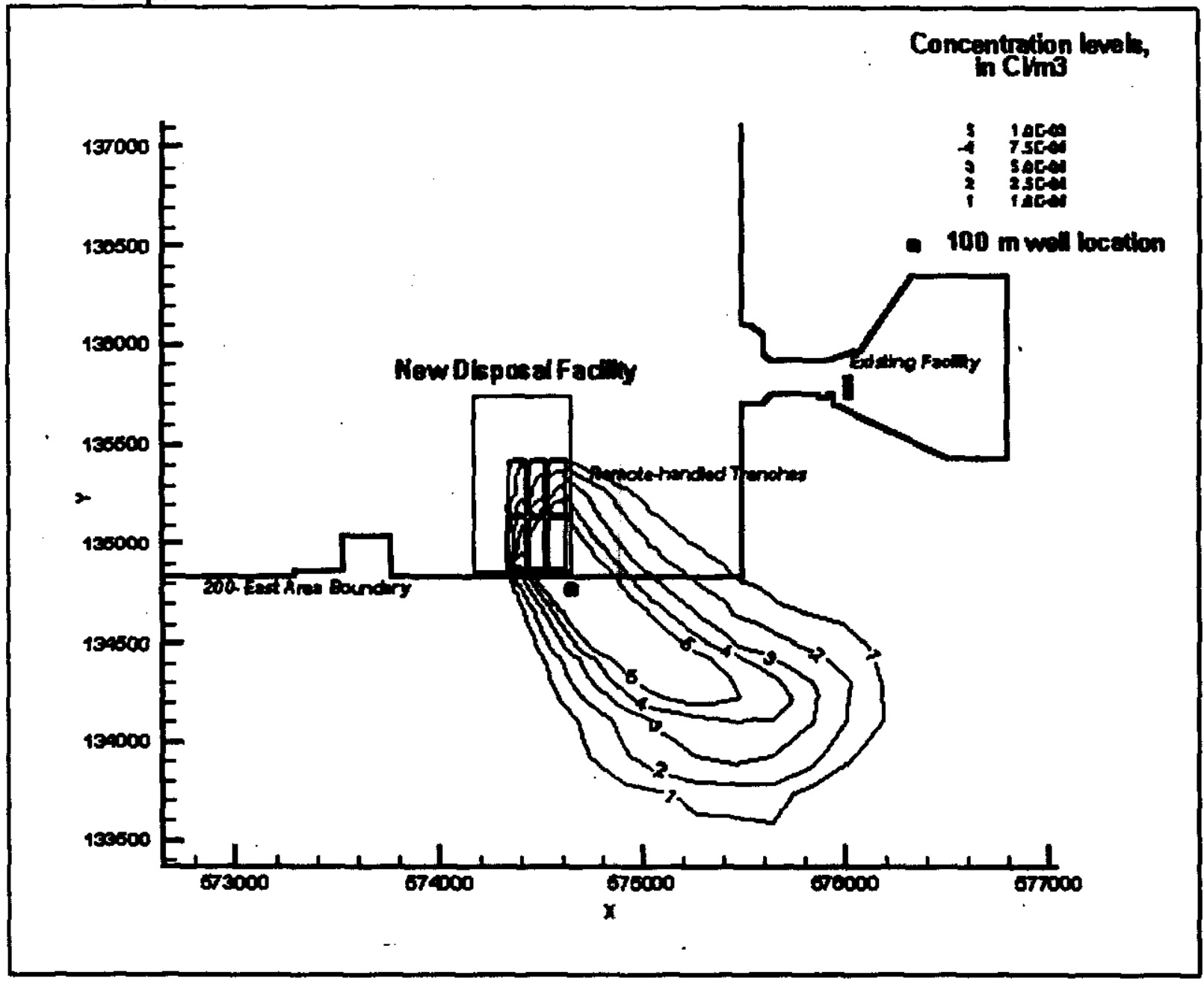

Simulated concentration histories at $100 \mathrm{~m}$ downgradient of the disposal facilities containing six trenches are presented in Figures 4.17 through 4.19. Figure 4.17 shows the distribution of contaminant concentration in the uppermost element of the local-scale model. Figure 4.18 ahows concentration profiles in a cross-section from the source area through the 100 $m$ well to the edge of the local scale model region. Figure 4.19 shows concentration histories at the $100 \mathrm{~m}$ well atter a period of 100 years after the source is introduced into the aquifer. In the multiple trench calculation the concentration profile reaches steady state within about $10 \mathrm{y}$ with a maximum value of $1.8 \times 10^{-3} \mathrm{Ci} / \mathrm{m}^{3}$. At an asamed recharge rate of $4.2 \mathrm{~mm} / \mathrm{y}$, the calculated WIF would be $1.8 \times 10^{-3} \mathrm{Ci} / \mathrm{m}^{3}$. The WIF factors for $4.2 \mathrm{~mm} / \mathrm{y}$ and other assumed infiltration rates are summarized in Table 4.1.

Although not presented graphically in this white paper, transport model results were also developed for the concrete vault concept based on local-scale flow conditions depicted in Figure 4.16. This concept was based on releases from eeven individual concrete vaults distributed in the new disposal facility area. WIFs were calculated at a distance of 100 meters downgradient from the facility as well as at an approximate distance of $1,000 \mathrm{~m}$ downgradient of the disposal facility 
boundaries. The WIF factors for $4.2 \mathrm{~mm} / \mathrm{y}$ and other assumed infiltration rates at this location are summarized in Table 4.2.

Table 4.2 Well Intercept Factors at $100 \mathrm{~m}$ and $1000 \mathrm{~m}$ for the Concrete Vault Disposal Concept Using Different Infiltration Rates

\begin{tabular}{|l|l|l|l|l|l|}
\hline & \multicolumn{5}{|c|}{ Infiltration rates $(\mathrm{mm} / \mathrm{y})$} \\
\hline Well Locations & 0.1 & 0.9 & 1.0 & 4.2 & 5.0 \\
\hline $100 \mathrm{~m}$ & $1.1 \times 10^{-5}$ & $9.7 \times 10^{-5}$ & $1.1 \times 10^{-1}$ & $4.5 \times 10^{-4}$ & $5.4 \times 10^{-4}$ \\
\hline $1000 \mathrm{~m}$ & $6.2 \times 10^{-6}$ & $5.6 \times 10^{-3}$ & $6.2 \times 10^{-5}$ & $2.6 \times 10^{-4}$ & $3.1 \times 10^{-4}$ \\
\hline
\end{tabular}

In the concrete vault calculation, the concentration profile at the $100 \mathrm{~m}$ well reaches steady state within about $10 \mathrm{y}$ with a maximum value of $4.5 \times 10^{-4} \mathrm{Ci} / \mathrm{m}^{3}$. At $1000 \mathrm{~m}$, the concentration profile reaches a steady state maximum value of $2.6 \times 10^{-4} \mathrm{Ci} / \mathrm{m}^{3}$. At an assumed recharge rate of $4.2 \mathrm{~mm} / \mathrm{y}$, the calculated WIF at the $100 \mathrm{~m}$ well would be $4.5 \times 10^{-4}$. The WIF factors for $4.2 \mathrm{~mm} / \mathrm{y}$ and other assumed infiltration rates at 100 and $1000 \mathrm{~m}$ respectively, are summarized in Table 4.2. The calculation assume the source is introduced from the vadose zone into the aquifer as a step function starting at time $t=0$.

Figure 4.18 Vertical Distribution of a Contaminant Plume Resulting the Remote-Handled Trench Concept Along the Approximate Centerline of the Plume

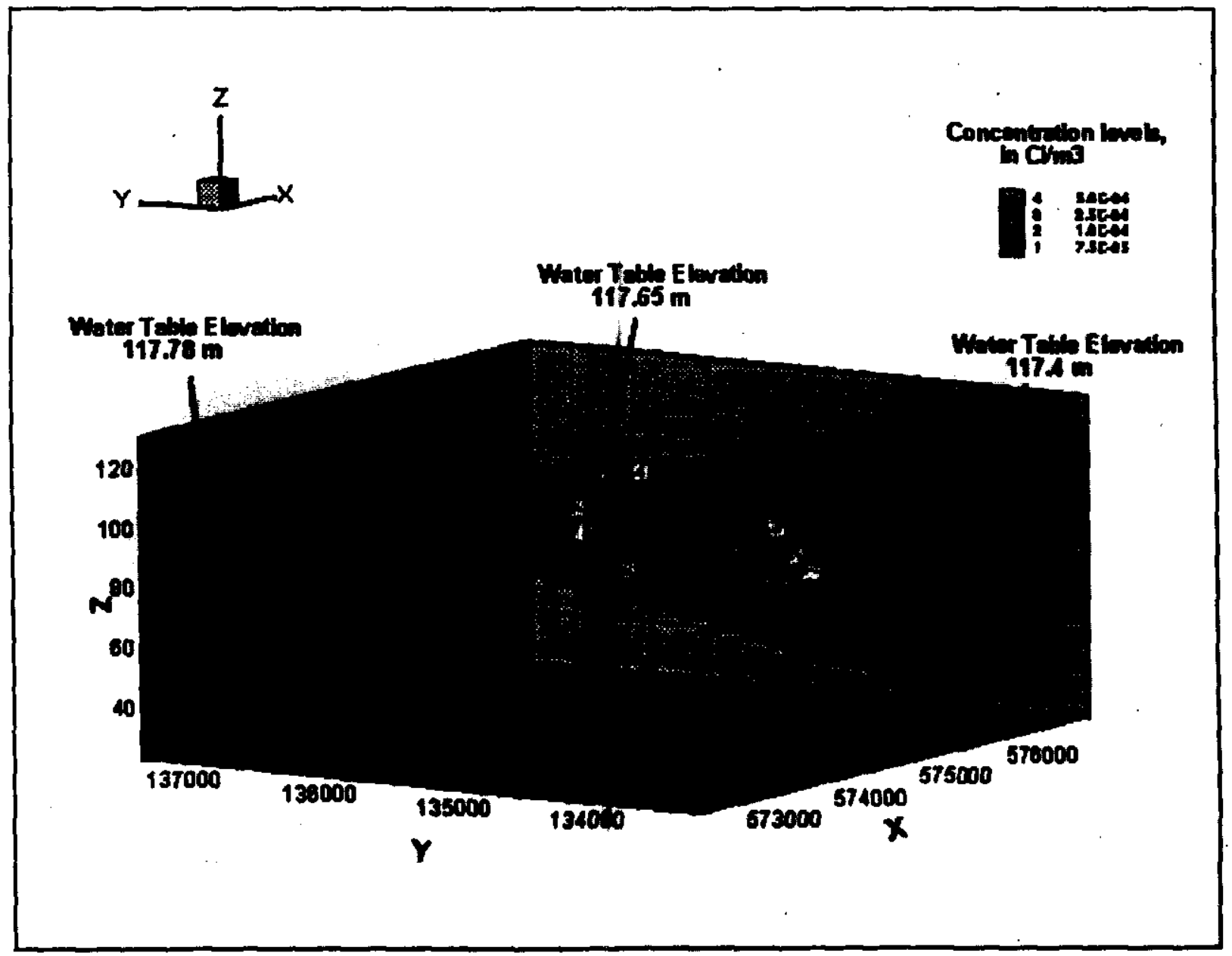


Figure 4.19 Concentration History at $100 \mathrm{~m}$ and $1000 \mathrm{~m}$ wells, Local Scale Model (Note the groundwater flux is greater than $100 \mathrm{~m} / 10 \mathrm{y}$ )

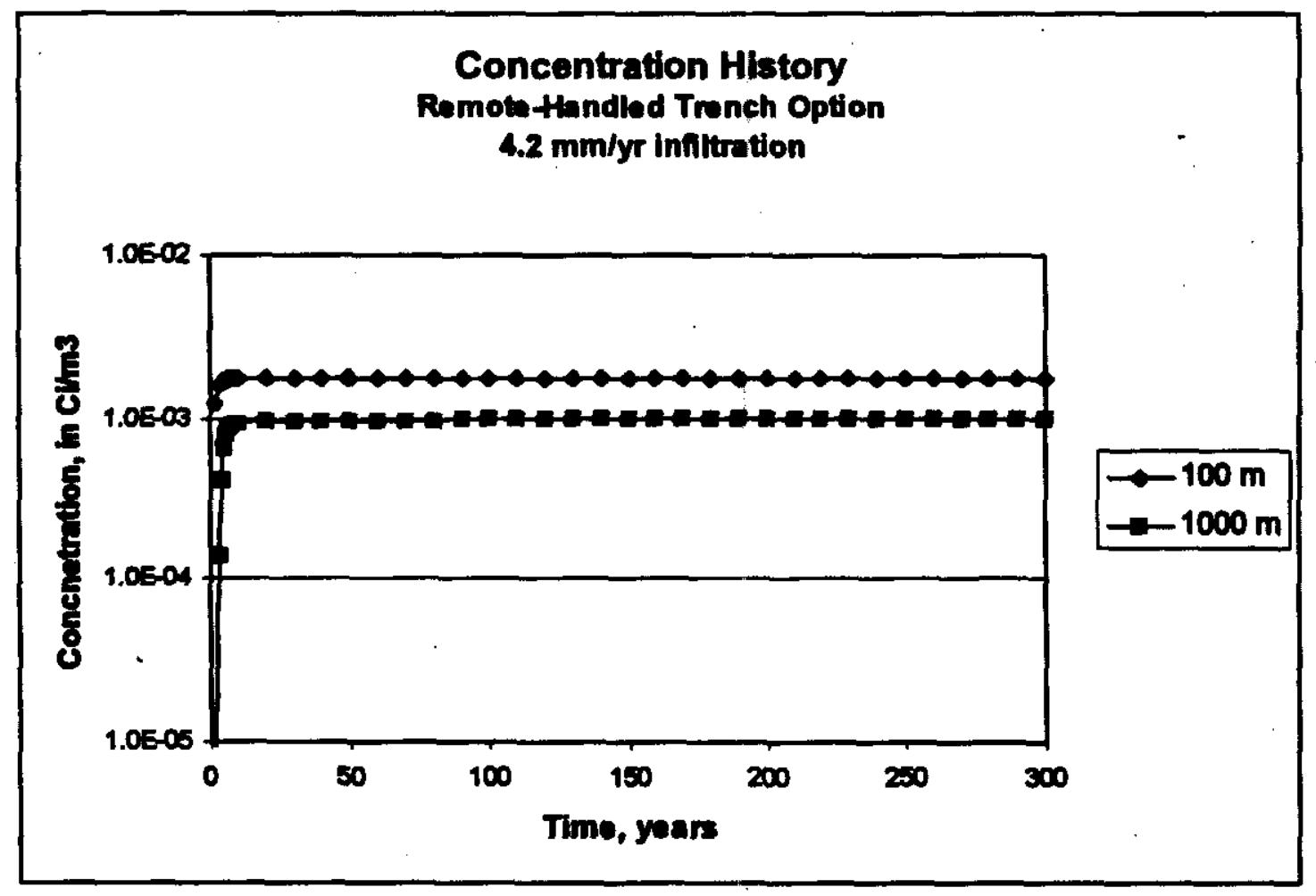

\subsubsection{Well-Intercept Factor at Distant Downgradient Wells}

Simulated concentration histories at several locations downgradient of the disposal facilities containing multiple remote-handled trenches are presented in Figures 4.20 and 4.21. Figure 4.20 show the distribution of contaminart concentration in the uppermost element of the local-scale model. Figure 4.21 shows concentration histories at the several well locations after a period of 400 years after the source is introduced into the squifer. In the multiple trench calculation, the concentration profile reaches steady state within about 30 to 50 years with a maximum value of $7.8 \times 10^{-4} \mathrm{Ci}^{3} \mathrm{~m}^{3}$ at the $1000 \mathrm{~m}$ well location. Steady state is reached within $400+$ years with a maximum value of $1.5 \times 10^{-4} \mathrm{Ci}^{3}$ at the well located near the Columbia River Considering the differences in grid resolution, the associated concentration levels at the $1000 \mathrm{~m}$ well location are very comparable to those calculated at the same approximate distance in the local scale model. At an assumed recharge ratc of $4.2 \mathrm{~mm} / \mathrm{y}$, the calculated concentration levels and WIFs would range from $7.8 \times 10^{-1}$ at $1000 \mathrm{~m}$ downgradient and $1.5 \times 10^{-4}$ at a hypothetical well near the Columbia River. The WIF factors for $4.2 \mathrm{~mm} / \mathrm{y}$ and other assumed infiltration rates at all locations examined are summarized in Table 4.3. In this regional-scale calculations, the WIF is reflective of the regional dilution of predicted concentrations between the facility and the Columbia River. These factors reflect the maximum concentration simulated at a particular location and not necessarily the concentration in all water withdrawn from a well. 
Table 4.3 Well Intercept Factors at Several Downgradient Well Locations for Remote Handled Trench Disposal Concept Using Different Infiltration Rates

\begin{tabular}{|c|c|c|c|c|c|}
\hline & \multicolumn{5}{|c|}{ Infiltration rates $(\mathrm{mm} / \mathrm{y})$} \\
\hline Well Locations ${ }^{(0)}$ & 0.1 & 0.9 & 1.0 & 4.2 & 5.0 \\
\hline $1.0 \mathrm{~km}$ & $1.8 \times 10^{-3}$ & $1.7 \times 10^{-4}$ & $1.8 \times 10^{-4}$ & $7.8 \times 10^{-2}$ & $9.3 \times 10^{-4}$ \\
\hline $3.1 \mathrm{~km}$ & $1.1 \times 10^{-5}$ & $9.5 \times 10^{-3}$ & $1.1 \times 10^{-4}$ & $4.5 \times 10^{-1}$ & $5.3 \times 10^{-1}$ \\
\hline $5 \mathrm{~km}$ & $8.5 \times 10^{-6}$ & $7.6 \times 10^{3}$ & $8.5 \times 10^{-3}$ & $3.6 \times 10^{-1}$ & $4.2 \times 10^{-4}$ \\
\hline $7.6 \mathrm{~km}$ & $7.8 \times 10^{-6}$ & $7.0 \times 10^{-3}$ & $7.8 \times 10^{-3}$ & $3.3 \times 10^{-4}$ & $3.9 \times 10^{-4}$ \\
\hline $9.3 \mathrm{~km}$ & $6.8 \times 10^{-6}$ & $6.1 \times 10^{-3}$ & $6.8 \times 10^{-5}$ & $2.9 \times 10^{-7}$ & $3.4 \times 10^{-4}$ \\
\hline $11.1 \mathrm{~km}$ & $5.7 \times 10^{-6}$ & $5.1 \times 10^{-5}$ & $5.7 \times 10^{-3}$ & $2.4 \times 10^{-1}$ & $2.8 \times 10^{-4}$ \\
\hline $14.8 \mathrm{~km}$ (river well) & $3.6 \times 10^{6}$ & $3.2 \times 10^{-5}$ & $3.6 \times 10^{-5}$ & $1.5 \times 10^{-4}$ & $2.8 \times 10^{-3}$ \\
\hline
\end{tabular}

(a) Well locations are shown in Figure 4.20; approximate downgradient distance from source

Figure 4.20 Areal Distribution of Contaminant Plume between ILAW New Facility and Columbia River, Remote Trench Concept

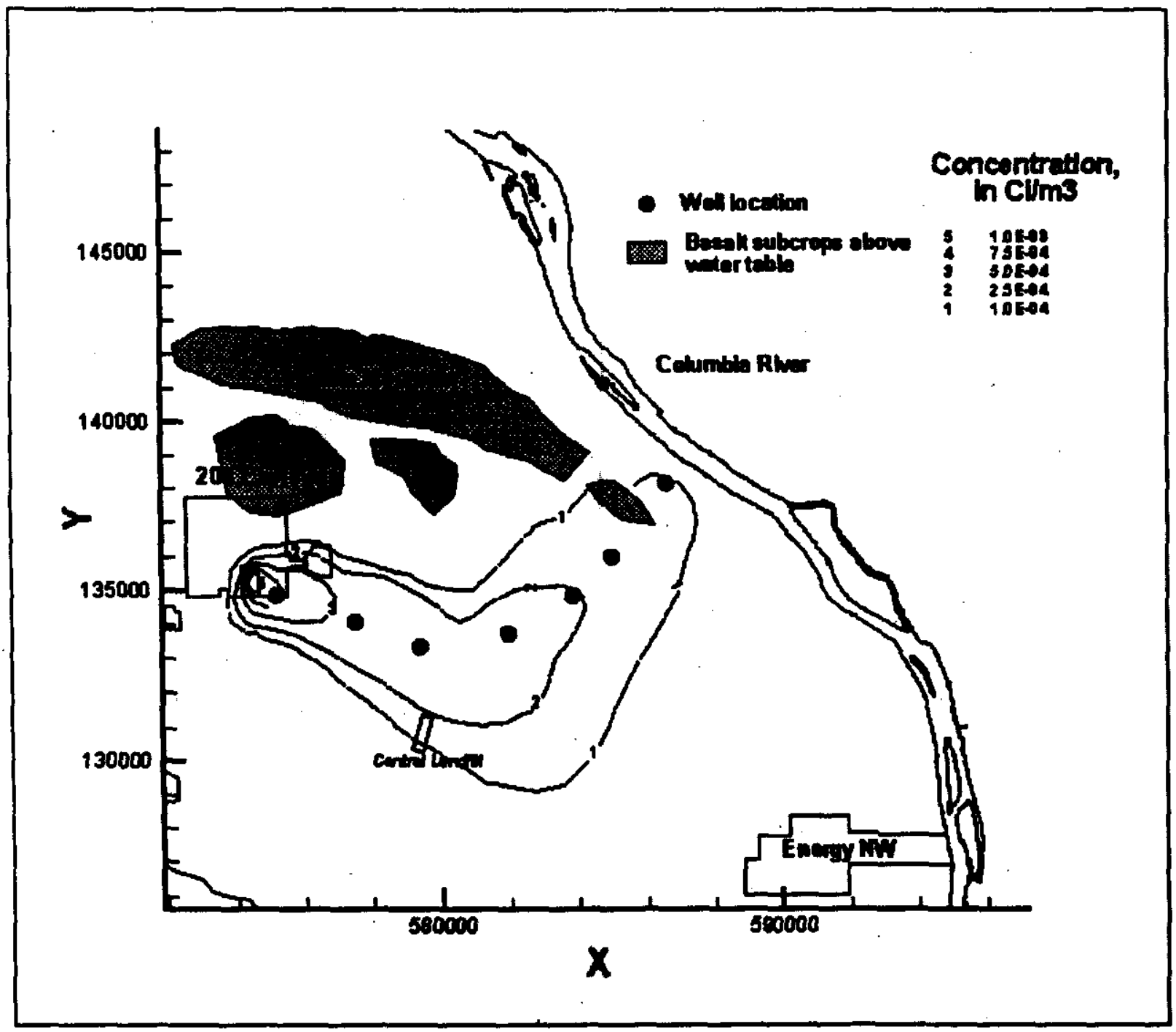


Figure 4.21 Concentration History at Selected Well Locations, Site-Wide Model

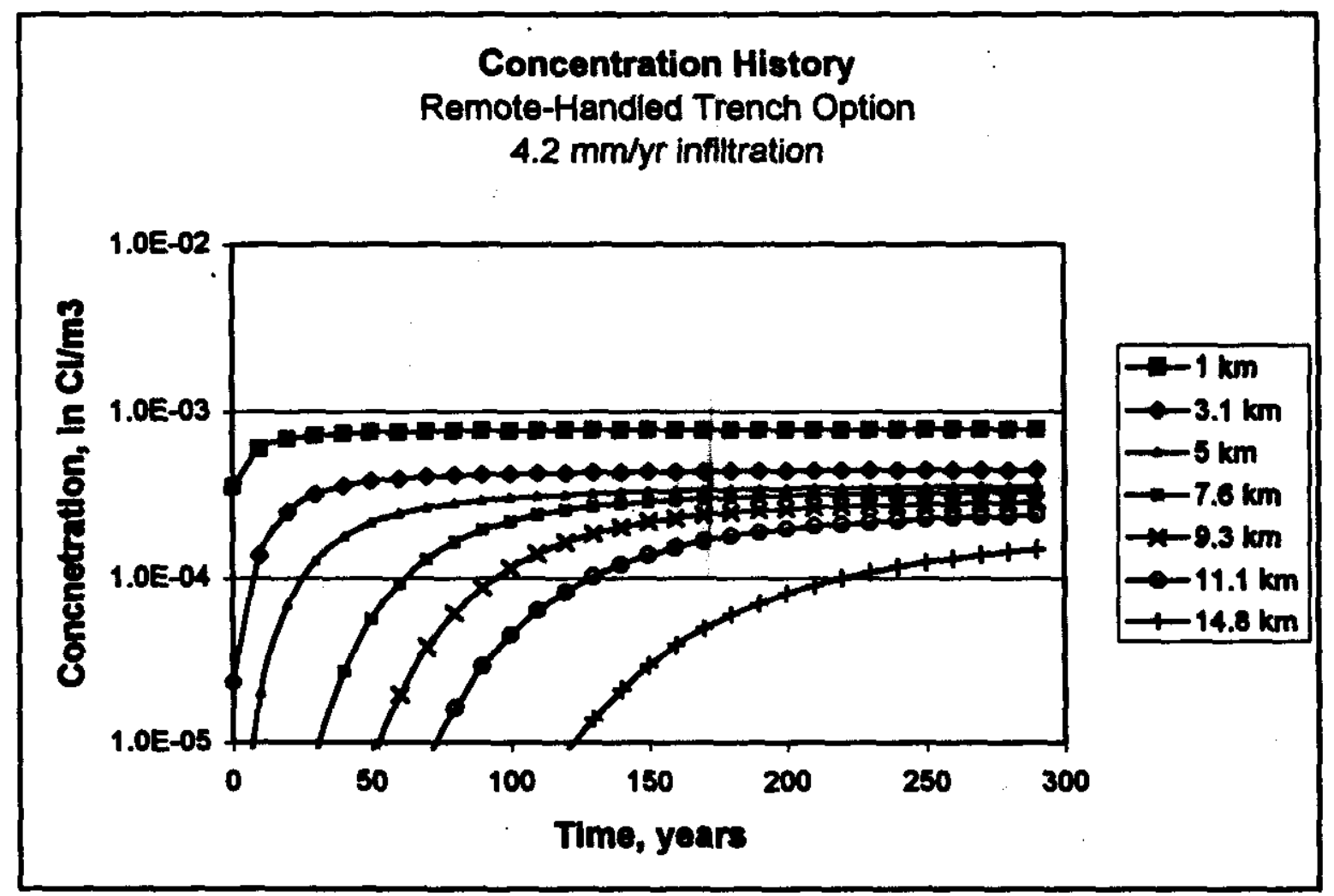

Simulated concentration histories at several locations downgradient of the disposal facilities containing multiple concrete trenches were also developed using the regional flow field described previously and illustrated in Figure 4.20. In the multiple concrete vault calculation, the concentration profile reaches steady state at the $1000 \mathrm{~m}$ well location within about 30 to 50 years with a maximum value of $3.32 \times 10^{-4} \mathrm{Ci}^{2} \mathrm{~m}^{3}$ assuming a recharge of $4.2 \mathrm{~mm} / \mathrm{y}$. Steady state is reached within $400+$ years at the well located near the Columbia River with a maximum value of $6.42 \times 10^{-5} \mathrm{Ci}^{3} \mathrm{~m}^{3}$. The associated WIF at the $1000 \mathrm{~m}$ well location is similar to those calculated at a similar distance in the local scale model. At an assumed recharge rate of 4.2 $\mathrm{mm} / \mathrm{y}$, the calculated WIFs would range from $3.32 \times 10^{-4}$ at $1000 \mathrm{~m}$ downgradient and $6.42 \times 10^{-5}$ at a hypothetical well near the Columbia River. The WIF factors for $4.2 \mathrm{~mm} / \mathrm{y}$ and other assumed infiltration rates at all locations examined are summarized in Table 4.4. 
Table 4.4 Well Intercept Factors at Several Downgradient Well Locations for Concrete Vault Disposal Concept Using Different Infiltration Rates

\begin{tabular}{|c|c|c|c|c|c|}
\hline & \multicolumn{5}{|c|}{ Infiltration rates $(\mathrm{mm} / \mathrm{y})$} \\
\hline Well Locations $^{(n)}$ & 0.1 & 0.9 & 1.0 & 4.2 & 5.0 \\
\hline $1.0 \mathrm{~km}$ & $5.0 \times 10^{-6}$ & $4.5 \times 10^{-3}$ & $5.0 \times 10^{-5}$ & $2.1 \times 10^{-4}$ & $2.5 \times 10^{-1}$ \\
\hline $3.1 \mathrm{~km}$ & $2.9 \times 10^{-6}$ & $2.6 \times 10^{-5}$ & $2.9 \times 10^{-5}$ & $1.2 \times 10^{-4}$ & $1.4 \times 10^{-7}$ \\
\hline $5 \mathrm{~km}$ & $2.3 \times 10^{-6}$ & $2.1 \times 10^{-3}$ & $2.3 \times 10^{-5}$ & $9.7 \times 10^{-3}$ & $1.2 \times 10^{-4}$ \\
\hline $7.6 \mathrm{~km}$ & $2.1 \times 10^{-6}$ & $1.9 \times 10^{-3}$ & $2.1 \times 10^{-5}$ & $8.9 \times 10^{-3}$ & $1.1 \times 10^{-3}$ \\
\hline $9.3 \mathrm{~km}$ & $1.9 \times 10^{-6}$ & $1.7 \times 10^{-5}$ & $1.9 \times 10^{-3}$ & $7.8 \times 10^{\circ}$ & $9.3 \times 10^{-3}$ \\
\hline $11.1 \mathrm{~km}$ & $1.5 \times 10^{-6}$ & $1.4 \times 10^{-5}$ & $1.5 \times 10^{-5}$ & $6.5 \times 10^{-5}$ & $7.7 \times 10^{-3}$ \\
\hline $14.8 \mathrm{~km}$ (river well) & $9.7 \times 10^{-7}$ & $8.8 \times 10^{-6}$ & $9.7 \times 10^{-5}$ & $4.1 \times 10^{-5}$ & $4.9 \times 10^{-5}$ \\
\hline
\end{tabular}

(a) Well locations are shown in Figure 4.20; approximate downgradient distance from source

\subsubsection{Discussion of Results}

Calculations of the well intercept factors in this analysis in general yielded different levels of dilution than those developed in previous calculations of ILAW disposal facility performance by $\mathrm{Lu}$ (1996). The differences in the calculated WIFs can be attributed to a number of factors:

- Distribution of hydrogeologic units and properties. Lu (1996) analysis estimated the water table beneath the facility to be at about the same level considered in this analysis but assumed the water table would be situated in Ringold Formation. The current model predicted that water table would largely be along the edge of a buried channel containing very permeable Hanford Formation. The difference in distribution and hydralic properties between the two conceptual models has led higher levels of dilution using the current model. Additional work with the current model will be needed to evaluate the predictability of the WIF as a function of the hydraulic properties of the major hydrogeologic units beneath the facility..

- Direction of how. Difference in the conceptual model of the unconfined aquifer used in the current analysis resulted in differences in the simulated direction of flow. Analysis by $\mathrm{Lu}(1996)$ predicted an sasterly flow direction. The current local-scale model predicts a southeasterly flow direction. This difference in flow direction may be primarily attributable to including the highly permeable ancestral channel of the Columbia River which contains the Hanford Formation in this analysis. The differences may also be a function of including of natural recharge in the current regional-scale and local-scale analysis. Further work with the local scale model will be needed to evaluate the predictability of the WIF as a function of the direction of flow.

Key factors affecting the current calculations appear to be related to the higher estimated hydraulic conductivities and groundwater velocities beneath the facility with the current model. The hydraulic conductivities between the currept model and the previous model used by $\mathrm{Lu}$ (1996) are on the same order of magnitude between 100 and $300 \mathrm{~m} /$ day. However, the current model contains areas of the Hanford formation beneath the facility and as a result has areas of 
very high permeability between several to tens of thousands $\mathrm{m} /$ day in the area of the source release.

A comparable analysis between the current model and the model by $\mathrm{Lu}(1996)$ of the concept 1 source yielded a dilution that was 30 times higher than previous analyzed by $\mathrm{Lu}$ (1996).

Areas of uncertainty that will have a bearing on the amount of actual dilution at the 100 $m$ well that will need to be more thoroughly investigated include the following:

- the vertical position of post-closure water table and the associated direction of groundwater flow

- the lateral position of Hanford-Ringold Formation Contact

- the hydraulic properties of Hanford and Ringold Sediments

\subsection{Summary of Groundwater Scenario}

The results from the combination of the waste form, far field, and groundwater calculations have been combined with the dosimetry information to provide estimated impacts for the proposed IIAW disposal action. Section 4.5.1 provides the results for the base analysis case associated with the RH trench concept and an infiltration rate of $4.2 \mathrm{~mm} / \mathrm{y}$. Section 4.5 .2 provides the results for the sensitivity case associated with the uncertainty in the II.AW inventory for the base analysis case. Section 4.5.3 provides the results for the disposal vault sensitivity cases that were explored. These cases include an alternate design concept (concrete vault) and a different recharge rate. Section 4.5.4 discusses the estimated impacts if the existing disposal vaults were used to dispose of IIAW waste. Section 4.5.5 provides an estimate of the impact of a one $\mathrm{Ci}$ surface contamination on the ILAW waste packages.

\subsubsection{Base Analysis Case}

The estimated impacts for the RH trench base analysis case compared to the groundwater scenarios are summarized in Table 4.5. Specifically, the impacts are estimated for 1,000 and 10,000 years after facility closure. Also shown in the table are the performance objectives for each scenario.

Table 4.5 Estimated Impact from the RH Trench Base Analysis Case at a Well 100 Meters Downgradient from the Disposal Facility

\begin{tabular}{|l|l|l|l|l|}
\hline $\begin{array}{l}\text { Protection of Groundwater } \\
\text { Impact Type }\end{array}$ & $\begin{array}{l}\text { Performance } \\
\text { Objective }\end{array}$ & $\begin{array}{l}\text { Estimated Impact } \\
\text { at 1,000 y }\end{array}$ & $\begin{array}{l}\text { Estimated Impact at 10,000 y } \\
1998 \text { ILAW PA Updated Results }\end{array}$ \\
\hline $\begin{array}{l}\text { Beta/Photon Drinking Water } \\
\text { Dose (mrem/y) }\end{array}$ & 4.0 & 0.0017 & 2.0 & 0.17 \\
\hline $\begin{array}{l}\text { Alpha Emitter Radiomuclide } \\
\text { Concentration (pCi/L) }\end{array}$ & 15.0 & $4.2 \times 10^{-14}$ & 1.7 & 0.13 \\
\hline $\begin{array}{l}\text { Radium Alpha Emitter } \\
\text { Concentration (pCi/L) }\end{array}$ & 5.0 & 0.0 & $<0.001$ & 0.0 \\
\hline All Pathways Dose(mrem/y) & 25.0 & 0.0061 & 6.4 & 0.72 \\
\hline
\end{tabular}




\section{DOE/ORP-2000-19, REV. 0 \\ Refrence: DOE/ORP-2000-07, REV. 0}

Figures 4.22 shows the time dependence of the drinking water dose out to 20,000 years after closure. The major contributors to the beta/photon drinking water doses at 10,000 years are listed in Table 4.6. From Figure 4.22 we see that ${ }^{99} \mathrm{Tc}$ and ${ }^{129} \mathrm{I}$ have comparable contributions to the dose at times less than 20,000 years. Contributions from beta emitters in the alpha decay chain have not been included in the estimates for the beta/photon drinking water dose. Therefore, ${ }^{99}$ Tc and ${ }^{129}$ I remain the major contributors out to 20,000 years. From Table 4.6 after ${ }^{99} \mathrm{Tc}$ and ${ }^{129}$ I contributes approximately 57 and $43 \%$ of the estimated dose, respectively, at 10,000 years.

Significant differences exist between this calculation and the results reported in the 1998 ILAW PA (Mann 1998a). These differences are attributable to differences in Kas used (see section 3.4.2.3) and differences in inventories (see section 3.2). In the 1998 ILAW PA (Mann 1998a) iodine had an assigned $\mathrm{K}_{d}=3 \mathrm{~mL} / \mathrm{g}$ and therefore did not contribute to the estimated dose during the first 10,000 years. Iodine has an assigned $\mathrm{K}_{d}=0 \mathrm{~mL} / \mathrm{g}$ for this analysis (based on site-specific measurements). Finally, ${ }^{79} \mathrm{Se}$, which was important in the 1998 ILAW PA, is no longer of significance due to its higher assigned $\mathrm{K}_{d}(4 \mathrm{~mL} / \mathrm{g})$ which is based on site-specific measurements and because of its reduced activity based on new half-life measurements.

Figure 4.22 Time Dependence for RH Trench Beta/Photon Drinking Water Dose to 10,000 Years

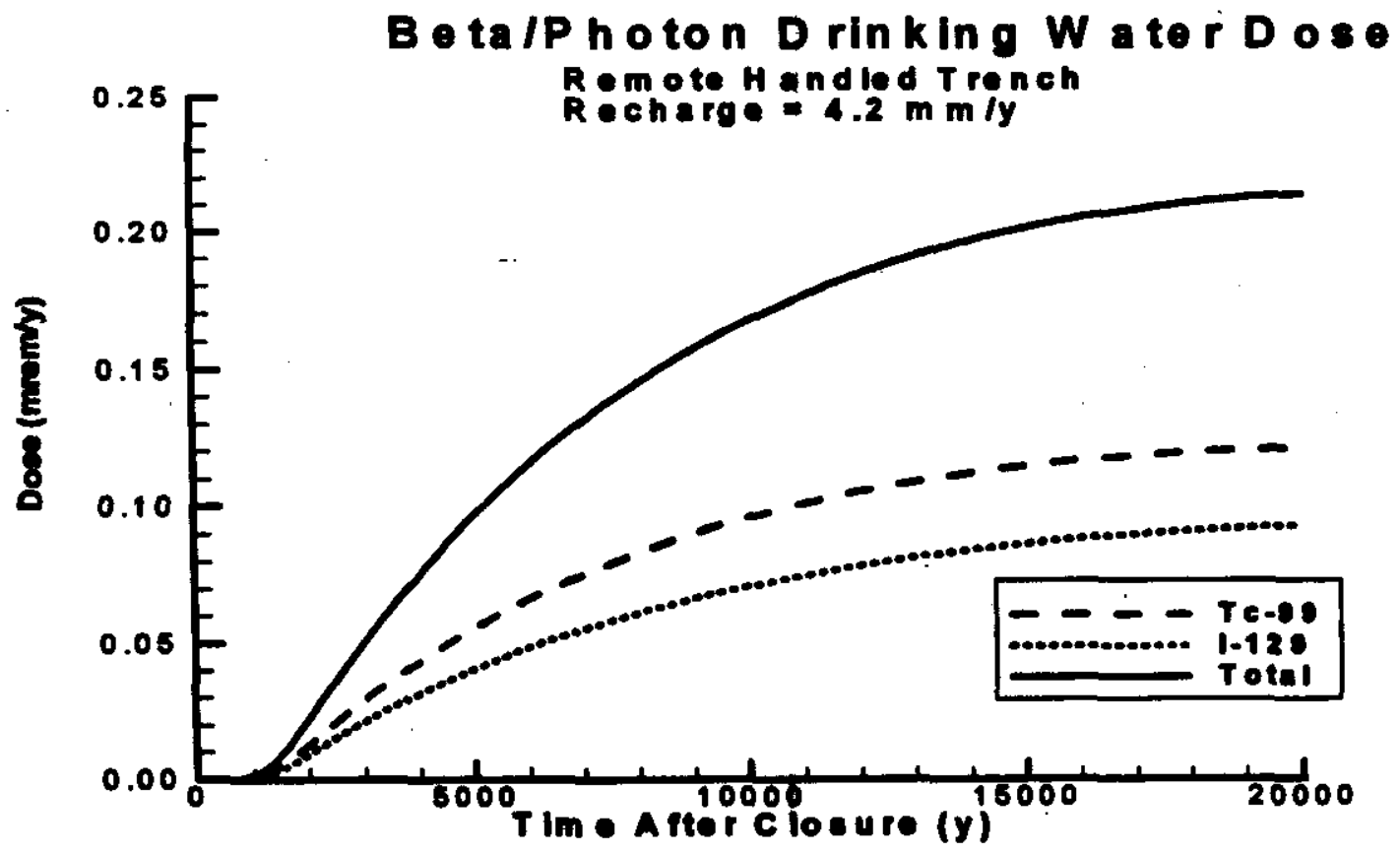


Table 4.6 RH Trench Base analysis case - Major Contributors at 10,000 Years to the Estimated Beta/Photon Drinking Water Dose at a Well 100 Meters Downgradient from the Disposal Facility

\begin{tabular}{|l|l|l|}
\hline Radionuclide & Dose (mrem/y) & $\begin{array}{l}\text { Concentration } \\
\text { (pCiL) }\end{array}$ \\
\hline${ }^{99} \mathrm{Tc}$ & 0.096 & 122.3 \\
\hline${ }^{29} \mathrm{I}$ & 0.072 & 0.48 \\
\hline Total & 0.168 & 122.8 \\
\hline
\end{tabular}

Figure 4.23 shows the time dependence of the alpha emitting radionuclide concentrations for the RH trench base analysis case. Also note that there is negligible contribution from alpha emitters to the concentration at 10,000 years. This is due to the assignment of $K_{d}>0 \mathrm{~mL} / \mathrm{g}$ to radionuclides that contribute to the alpha emitting radionuclide concentration. From Figure 4.13 we saw that $\mathrm{K}_{d}=0.6 \mathrm{~mL} / \mathrm{g}$ radionuclides begin to reach the groundwater after approximately 10,000 years for the base analysis case. See Table 4.7 for details.

Figure 4.23 Time Dependence for Apha Emitting Radionuclide Concentrations Alpha Emitter Concentration in Aquifer

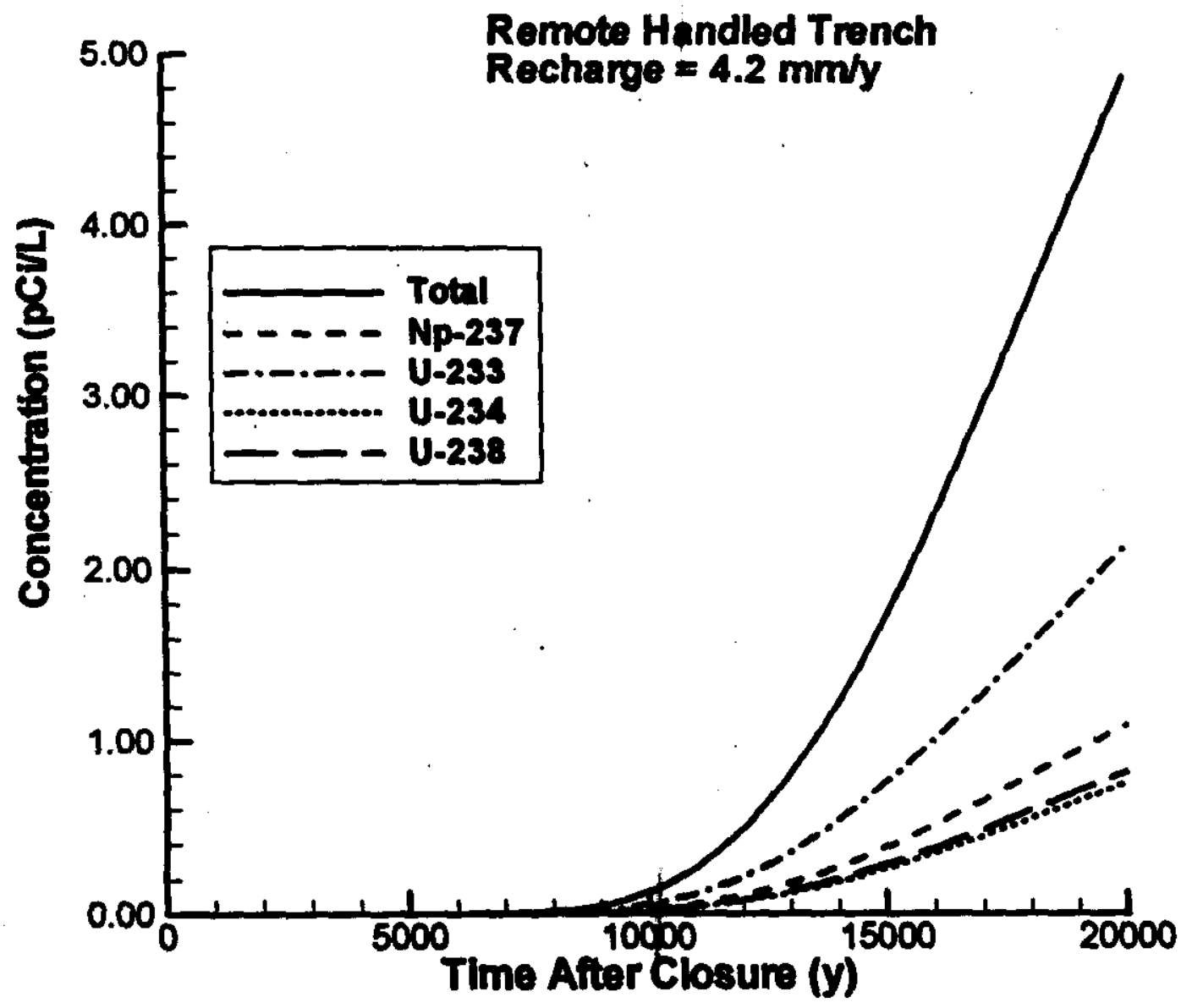


Table 4.7 Major Contributors at 10,000 Years to the Alpha Emitting Radionuclide Concentration at a Well 100 Meter Downgradient from the Disposal Facility

\begin{tabular}{|l|l|l|}
\hline Radionuclide & Dose (mrem/y) & $\begin{array}{l}\text { Concentration } \\
(\mathrm{pCi} / \mathrm{L})\end{array}$ \\
\hline${ }^{237} \mathrm{~Np}$ & 0.068 & 0.028 \\
\hline${ }^{233} \mathrm{U}$ & 0.009 & 0.056 \\
\hline${ }^{234} \mathrm{U}$ & 0.003 & 0.019 \\
\hline $238 \mathrm{U}$ & 0.003 & 0.021 \\
\hline Others & 0.002 & 0.002 \\
\hline Total & 0.085 & 0.127 \\
\hline
\end{tabular}

Significant differences exist between this calculation and the results reported in the 1998 IIAW PA (Mann 1998a). These differences are attributable to differences in $\mathrm{K}_{\phi} \mathrm{used}$ (see section 3.4.2.3) and differences in inventories (see section 3.2). In the 1998 ILAW PA (Mann $1998 \mathrm{a})^{237} \mathrm{~Np}$ had a Kd $=15 \mathrm{~mL} / \mathrm{g}$ and therefore did not contribute to the estimated dose during the firct 10,000 years. ${ }^{237}$ Np has an assigned $\mathrm{K}_{d}=0.6 \mathrm{~mL} / \mathrm{g}$ for this analysis (based on site specific measurements and the decision to make "gravel-corrections" to Kd's determined on only the sand, silt, and clay portions of the actual sediment). Because the actual sediment contains appreciable amounts of larger material (gravel) we elected to lower the Kd used to represent the field conditions. Therefore, ${ }^{237}$ Np now contributes to the estimated dose at 10,000 years. Moreover, the estimated inventory used in this apalysis (see Table 3.1) is significantly larger than the inventory estimate used in the 1998 ILAW PA. This larger ILAW inventory is due to a larger tank inventory estimate from the BBI and smaller separations factor $(-0.5$ versus $\sim 0.94)$ based on Kirkbride (1999).

Figure 4.24 shows the time dependence of the all-pathways dose for the RH trench base analysis case. The major contributors to this dose are shown in Table 4.8 .

Table 4.8 Major Contributors at 10,000 Years to the All Pathways Dose at a Well 100 Meter Downgradient from the RH Trench Disposal Facility

\begin{tabular}{|l|l|l|}
\hline Radionuclide & Dose (mrem/y) & $\begin{array}{l}\text { Concentration } \\
(\mathrm{pCi} / \mathrm{L})\end{array}$ \\
\hline${ }^{95} \mathrm{Tc}$ & 0.43 & 122.3 \\
\hline${ }^{125} \mathrm{I}$ & 0.18 & 0.48 \\
\hline${ }^{235} \mathrm{~Np}$ & 0.08 & 0.06 \\
\hline${ }^{235} \mathrm{U}$ & 0.01 & 0.06 \\
\hline Others & 0.01 & 0.01 \\
\hline Total & 0.72 & 122.9 \\
\hline
\end{tabular}

As seen in Table $4.8{ }^{92} \mathrm{Tc}$ and ${ }^{129} \mathrm{I}$ are the major contributors to the all pathways dose at 10,000 years after the facility closure. However, at times greater than 10,000 years ${ }^{237} \mathrm{~Np}$ starts to dominate the all pathways dose. 
Figure 4.24 Time Dependence for All Pathway Doses for RH Trench

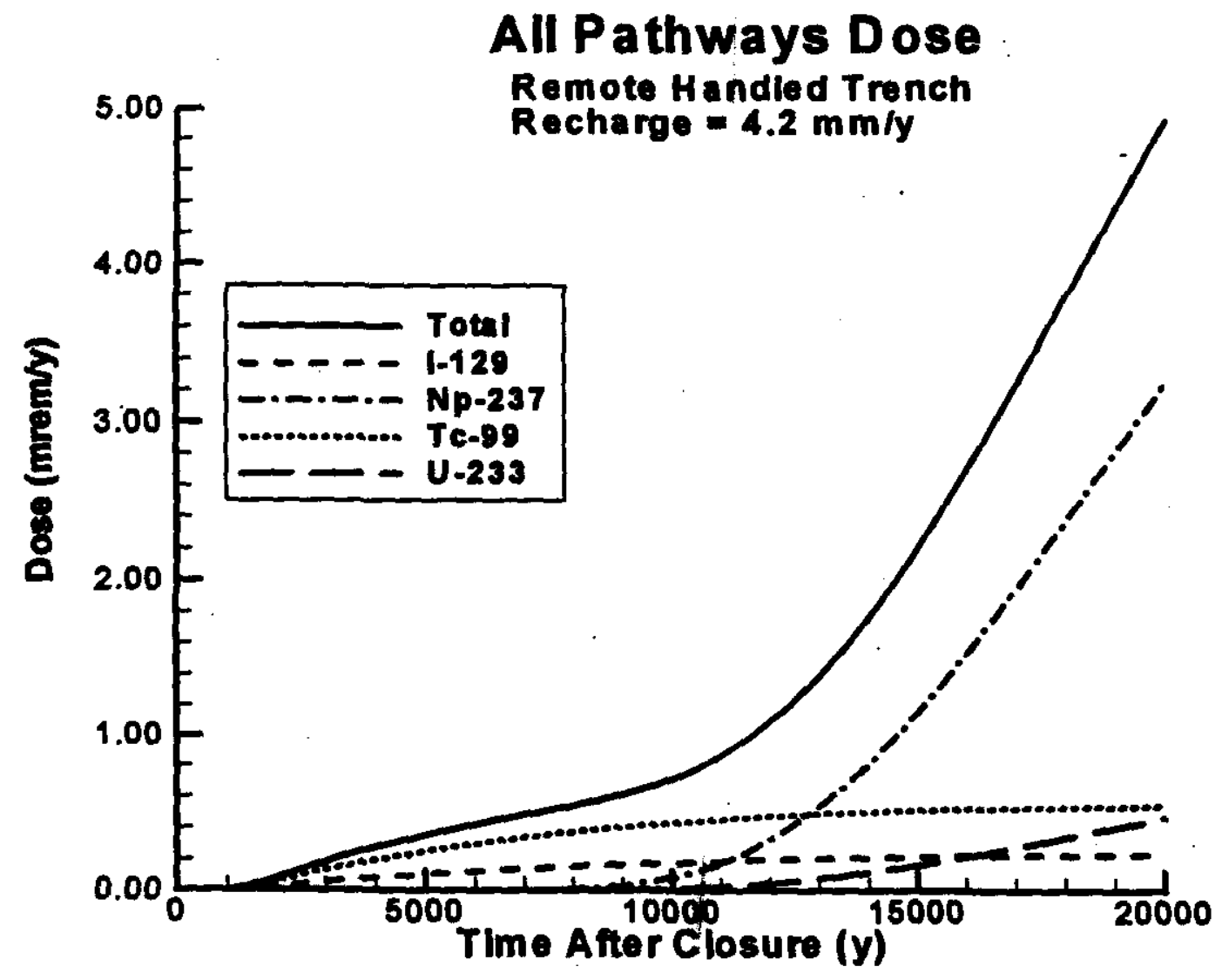

Table 4.9 shows the estimated impact from the base analysis case for groundwater just before mixing with the Columbia River. These estimated impacts are approximately an order of magnitude less than the impacts at a well 100 in downgradient from the disposal site because of the additional dilution that occurs as the contaminants travel to the Columbia River.

Table 4.9 Estimated Impact from the Base Analysis Case from Groundwater Just Before Mixing with the Columbia River

\begin{tabular}{|l|l|l|l|l|}
\hline $\begin{array}{l}\text { Protection of Groundwater } \\
\text { Impact Type }\end{array}$ & $\begin{array}{l}\text { Performance } \\
\text { Objective }\end{array}$ & $\begin{array}{l}\text { Estimated Impact } \\
\text { at 1,000 y }\end{array}$ & $\begin{array}{l}\text { Estimated Impact at 10,000 y } \\
1998 \text { LAW PA Updated Results }\end{array}$ \\
\hline $\begin{array}{l}\text { Beta/Photon Drinking Water } \\
\text { Dose (mrem/y) }\end{array}$ & 1.0 & $1.4 \times 10^{-4}$ & 0.070 & 0.014 \\
\hline $\begin{array}{l}\text { Alpha Emitter Radionuclide } \\
\text { Concentration (pCi/L) }\end{array}$ & 15.0 & $6.8 \times 10^{-16}$ & 0.058 & 0.11 \\
\hline $\begin{array}{l}\text { Radium Alph Emitter } \\
\text { Concentration (pCi/L) }\end{array}$ & 0.3 & 0.0 & $<0.001$ & 0.0 \\
\hline
\end{tabular}

Finally, the estimated impacts for the hazardous, non-radioactive compounds and elements have been estimated for the hazardous materials identifiod in Table 1.2. For this analysis these materials have been assigned a chemical adsorption coefficient of $K_{d}=0 \mathrm{~mL} / \mathrm{g}$. 
The resulting estimated concentrations in the groundwater at a well 100 meters downgradient from the disposal facility are shown in Table 4.10. Estimated impacts at 10,000 years were derived for both the nominal and upper bound inventories in Table 3.1. As can be seen in the table the nominal goals established for these hazardous materials are easily met for the glass waste form and disposal facility.

The resulting estimated concentrations in the surface water are shown in Table 4.11 for both the nominal and upper bound inventories at 10,000 years. These estimates are calculated for a well next to the Columbia River and before any mixing with the river. As can be seen in the table the nominal goals established for these hazardous materials are easily met for the glass waste form and disposal facility.

The calculations thus far have been for the nominal ILAW inventory as listed in Table 3.1. Table 3.1 also provides an estimate for the upper bound inventory in ILAW from Wootan (1999). The estimated impacts from the assumption that the upper bound inventory were estimated using INTEG and are summarized in Table 4.12.

From the analyses ${ }^{99} \mathrm{Tc}$ and ${ }^{129} \mathrm{I}$ were found to be the major contributors. However, the estimated impacts related to the protection of the groundwater are still more than an order of magnitude less than the corresponding performance objectives.

The estimated impacts for the disposal facility sensitivity case for the concrete vault compared to the groundwater scenarios are summarized in Table 4.13. These calculations were performed for the nominal IIAW inventory given in Table 3.1. The impacts are estimated for 1,000 and 10,000 years after facility closure. Also shown in the table are the performance objectives for each scenario.

Finally, the estimated impacts for the disposal facility sensitivity case for the recharge rate of $0.9 \mathrm{~mm} / \mathrm{y}$ compared to the groundwater scenarios are summarized in Table 4.14.

Specifically, the impacts are estimated for 1,000 and 10,000 years after facility closure. Also shown in the table are the performance objectives for each scenario.

The last IIAW performance assessment considered the disposal of the IIAW waste at two locations: the present ILAW disposal site ind the existing grout vault disposal site. The current direction from the DOE (Taylor 1999a) is to utilize the IIAW disposal site for waste disposal. The existing grout vault site is to be netained for possible future disposal needs. As a sensitivity case, we have assumed that this disposal site with its existing disposal vaults may be used for disposal of ILAW waste. 


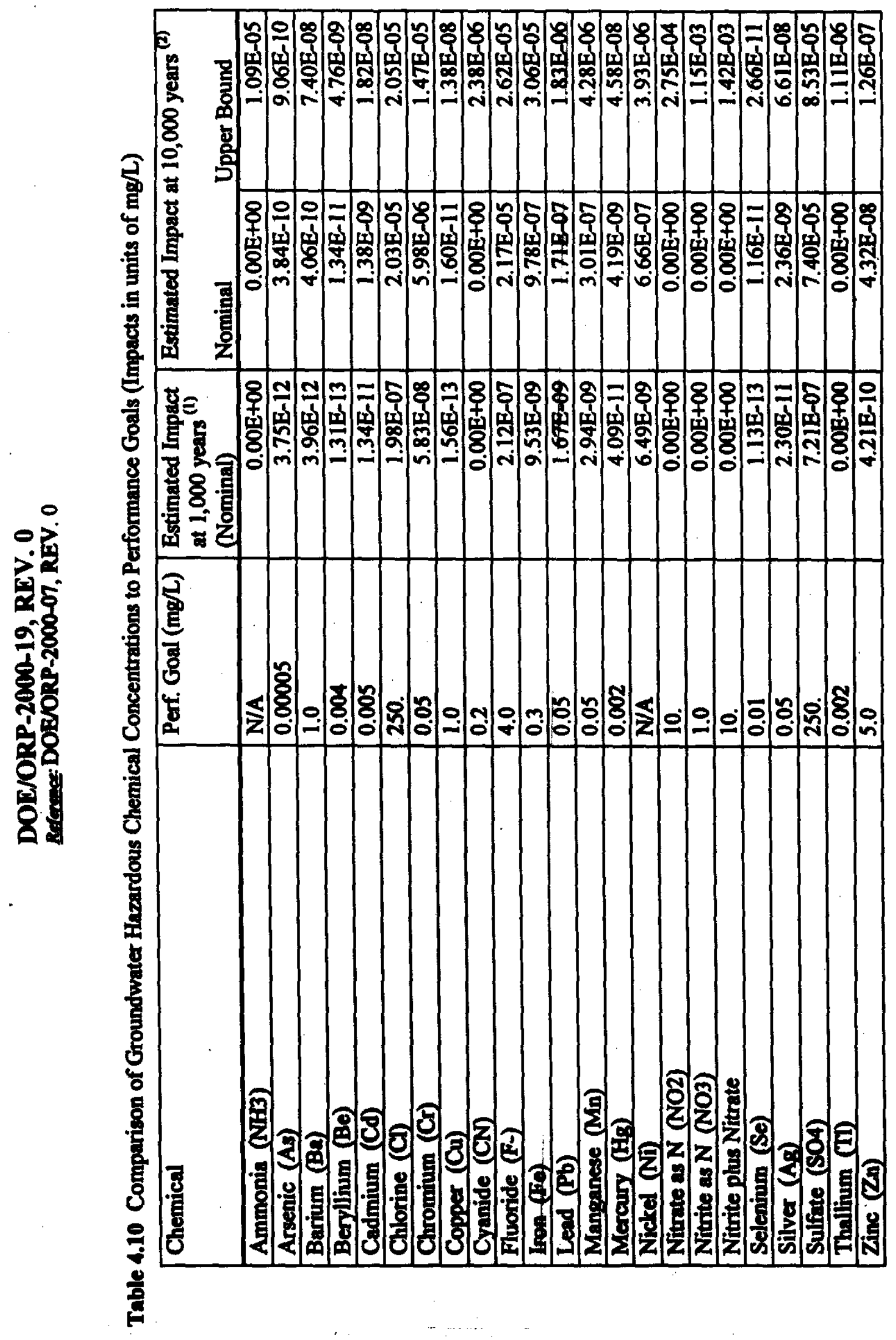




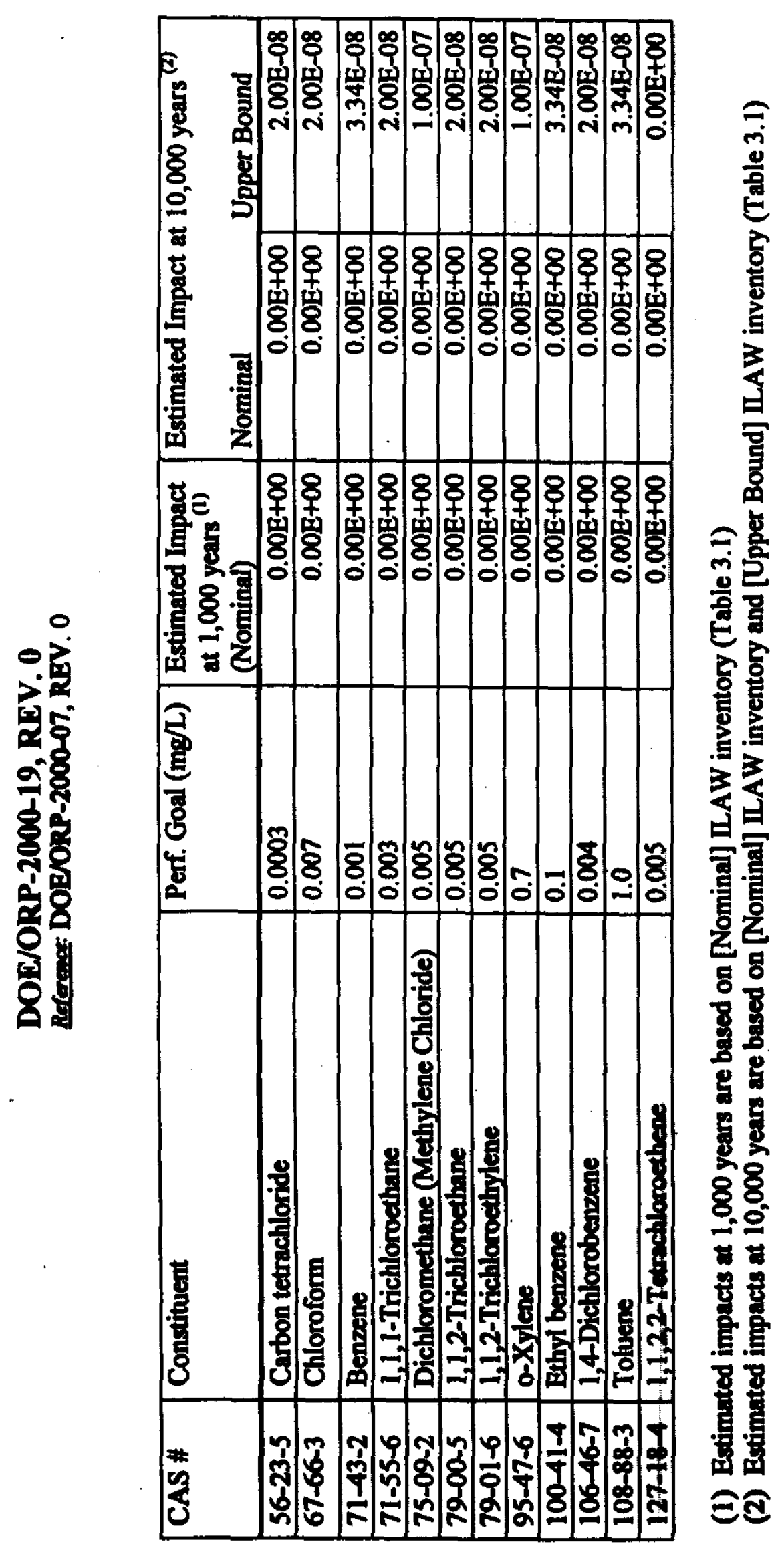




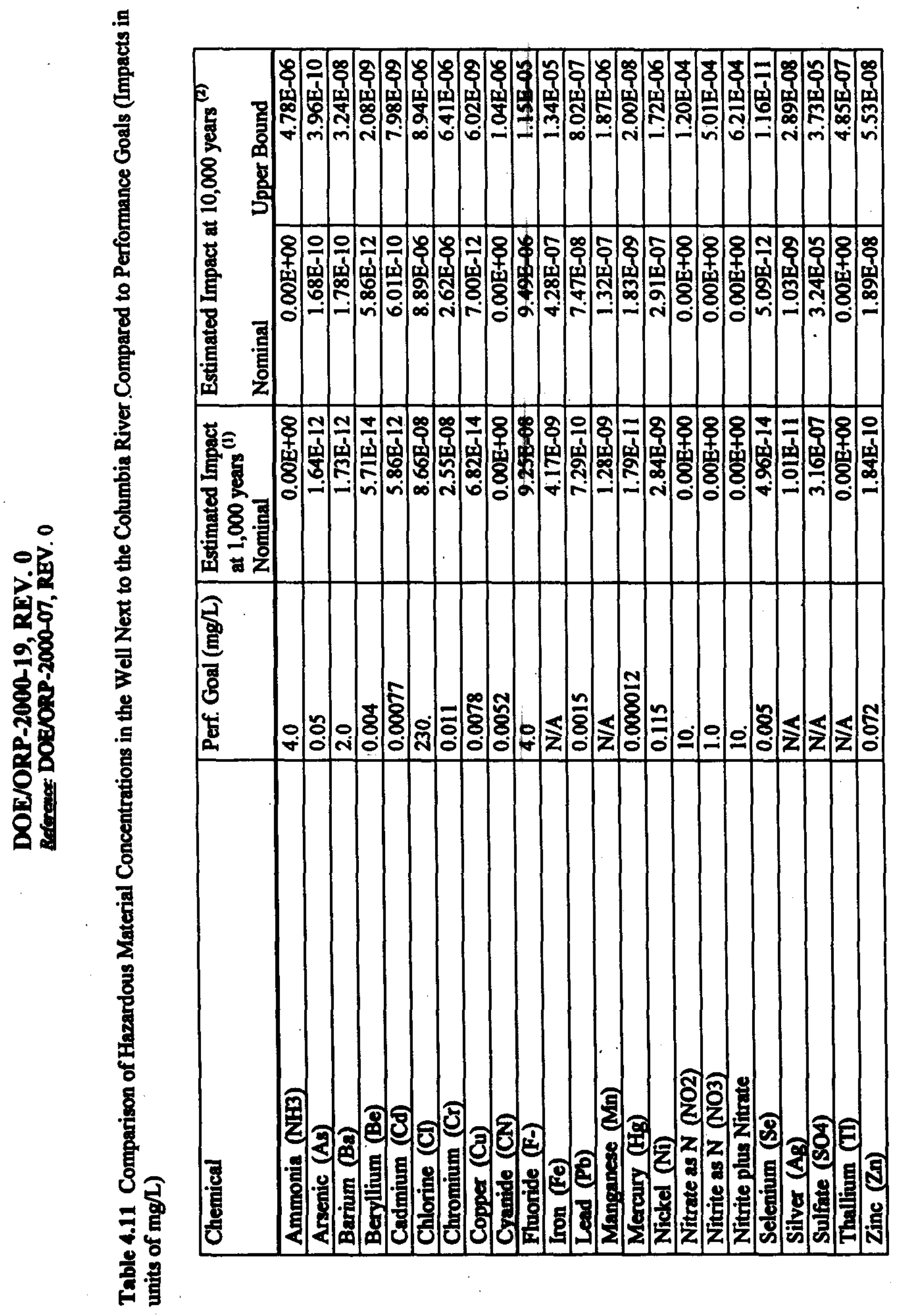




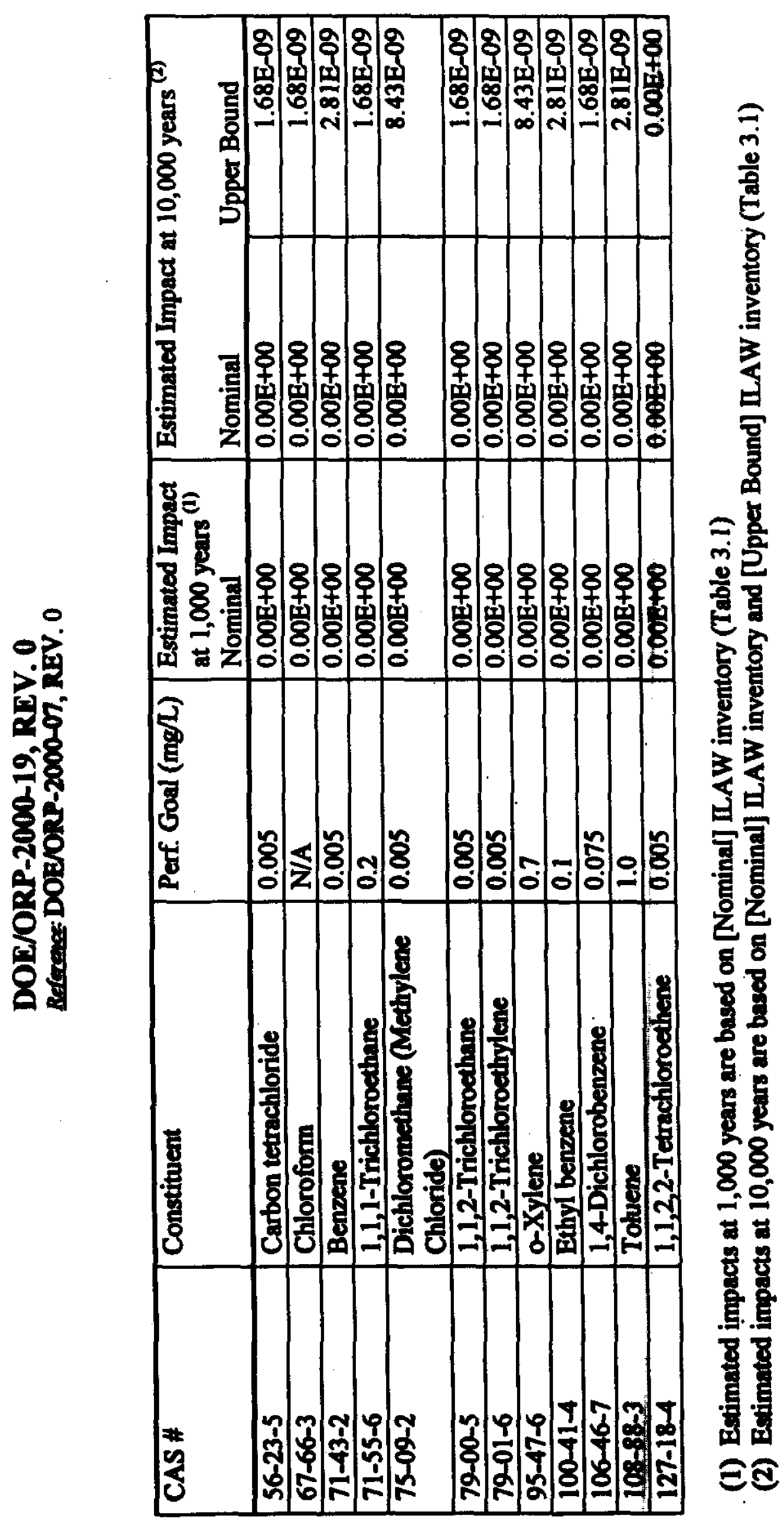


Table 4.12 Estimated Impact from the RH Trench Base Analysis Case at a Well 100 Meters Downgradient from the Disposal Facility Using Upper Bound IIAW Inventory. See Table 4.5 for comparison to the base case.

\begin{tabular}{|l|l|l|l|l|}
\hline $\begin{array}{l}\text { Protection of Groundwater } \\
\text { Impact Type }\end{array}$ & $\begin{array}{l}\text { Performance } \\
\text { Objective }\end{array}$ & $\begin{array}{l}\text { Estimated Impact } \\
\text { at } 1,000 \mathrm{y}\end{array}$ & $\begin{array}{l}\text { Estimated Impact at } 10,000 \mathrm{y} \\
1998 \text { ILAW PA }\end{array}$ Updated Results \\
\hline $\begin{array}{l}\text { Beta/Photon Drinking Water } \\
\text { Dose (mrem/y) }\end{array}$ & 4.0 & 0.0081 & 2.0 & 0.81 \\
\hline $\begin{array}{l}\text { Alpha Emitter Radionuclide } \\
\text { Concentration (pCi/L) }\end{array}$ & 15.0 & $3.8 \times 10^{-14}$ & 1.7 & 0.70 \\
\hline $\begin{array}{l}\text { Radium Alpha Emitter } \\
\text { Concentration (pCi/L) }\end{array}$ & 5.0 & 0.0 & $<0.001$ & 0.0 \\
\hline All Pathways Dose(mrem/y) & 25.0 & 0.030 & 6.4 & 3.77 \\
\hline
\end{tabular}

Table 4.13 Estimated Impact from the Alternate Disposal Facility Design Case (Concrete Vault Design) at a Well 100 Meters Downgradient from the Disposal Facility Using the Nominal ILAW Inventory. See Table 4.5 for comparison to the base case.

\begin{tabular}{|l|l|l|l|}
\hline $\begin{array}{l}\text { Protection of Groundwater } \\
\text { Impact Type }\end{array}$ & $\begin{array}{l}\text { Performance } \\
\text { Objective }\end{array}$ & $\begin{array}{l}\text { Estimated Impact } \\
\text { at } 1,000 \mathrm{y}\end{array}$ & $\begin{array}{l}\text { Estimated Impact } \\
\text { at } 10,000 \mathrm{y}\end{array}$ \\
\hline $\begin{array}{l}\text { Beta/Photon Drinking Water } \\
\text { Dose (mrem/y) }\end{array}$ & 4.0 & 0.024 & $0.29(\mathrm{o})$ \\
\hline $\begin{array}{l}\text { Alpha Emitter Radionuclide } \\
\text { Concentration (pCi/L) }\end{array}$ & 15.0 & $1.2 \times 10^{-13}$ & 1.9 \\
\hline $\begin{array}{l}\text { Radium Alpha Emitter } \\
\text { Concentration (pCi/L) }\end{array}$ & 5.0 & 0.0 & 0.0 \\
\hline All Pathways Dose(mrem/y) & 25.0 & 0.088 & 2.7 \\
\hline
\end{tabular}

Table 4.14 Estimated Impact from the Waste Form Sensitivity Case (Recharge $=0.9 \mathrm{~mm} / \mathrm{y}$ ) at a Well 100 Meters Downgradient from the Disposal Facility

\begin{tabular}{|l|l|l|l|}
\hline $\begin{array}{l}\text { Protection of Groundwater } \\
\text { Impact Type }\end{array}$ & $\begin{array}{l}\text { Performance } \\
\text { Objective }\end{array}$ & $\begin{array}{l}\text { Estimated Impact } \\
\text { at } 1,000 \mathrm{y}\end{array}$ & $\begin{array}{l}\text { Estimated Impact } \\
\text { at } 10,000 \mathrm{y}\end{array}$ \\
\hline $\begin{array}{l}\text { Beta/Photon Drinking Water } \\
\text { Dose (mrem/y) }\end{array}$ & 4.0 & $3.8 \times 10^{-10}$ & 0.012 \\
\hline $\begin{array}{l}\text { Alphs Emitter Radionuclide } \\
\text { Concentration (pCi/L) }\end{array}$ & 15.0 & $1.8 \times 10^{-21}$ & $5.7 \times 10^{-14}$ \\
\hline $\begin{array}{l}\text { Radium Alpha Emitter } \\
\text { Concentration (pCi/L) }\end{array}$ & 5.0 & 0.0 & 0.0 \\
\hline $\begin{array}{l}\text { All Pathways Dose } \\
\text { (mrem/y) }\end{array}$ & 25.0 & $1.4 \times 10^{-9}$ & 0.042 \\
\hline
\end{tabular}


The existing vaults are described in Puigh (1999). The vault inner floor dimensions are $15.4 \mathrm{~m} \times 37.6 \mathrm{~m}$ and its height is $12.2 \mathrm{~m}$. Each vault is capable of holding $10 \times 25$ waste packages in a layer and a total of 7 layers within a given vault. For this analysis we have assumed the performance of the existing vaults to be similar to the concrete vault calculations described in section 4.2 and 4.3. To extrapolate these results to the existing disposal vaults the following assumptions have been made: 1) the normalized contaminant release rate from the existing vaults is equal to the calculated release rates for the new concrete vaults described in section 4.2, 2) the differences the vadose zone stratigraphy and hydraulic properties can be ignored, and 3) the WIF at $100 \mathrm{~m}$ downgradient for the ILAW disposal site and the existing vault disposal site are the same.

Given these assumptions the estimated impacts from loading waste into the existing vaults can be estimated. The estimate depends solely on the ratio of total waste inventory that can be placed into each vault concept and the footprint of the disposal facility. Six concrete vaults having the new design can contain 66,528 waste packages and has a facility footprint of $25,931 \mathrm{~m} 2$. The four existing vaults (modification described in Puigh 1999) can contain 7,000 waste packages and has a facility footprint of $2,316 \mathrm{~m}^{2}$. Therefore, the results for the estimated impacts given in Table 4.13 should be multiplied by a factor of 1.2 to estimate the impacts from IIAW waste disposed of in the existing vaults.

\subsubsection{Surface Contamination Release}

From section 4.3.5 the peak contaminant flux into the aquifer from a $1 \mathrm{Ci}$ source over one year is $1.0 \times 10^{-3} \mathrm{Ci} / \mathrm{y} / \mathrm{Ci}$. For the RH trench base analysis case this corresponds to the concentration in the groundwater beneath the facility of $1 \times 10^{4} \mathrm{pCi} / \mathrm{L}$ for each $\mathrm{Ci}$ of contaminant with an effective $K_{d}=0 \mathrm{~mL} / \mathrm{g}$. For contaminants with effective $K_{d}=0.6 \mathrm{~mL} / \mathrm{g}$, the corresponding peak concentration in the groundwater beneath the facility is $1 \times 10^{3} \mathrm{pCi} / \mathrm{L}$ for each Ci of contaminant.

The impact on the performance objectives for groundwater will depend upon the specific soluble radionuclides on the waste package surfaces at the time of their emplacement into the facility. For example, if there were $1 \mathrm{Ci}$ of ${ }^{99} \mathrm{Tc}$ on the surfaces of the waste packages, then the peak drinking water estimated impact would be $1.4 \times 10^{-2} \mathrm{mrem}$ in a year.

\subsection{Effects of Natural Events}

The main natural events to be evaluated are: 1) potential erosion of the surface above the disposal unit due to wind, 2) subsidence of the engineered barriers or facilities, 3) earthquakes, and 4) flooding due to post-glacial events. The new facility concept now includes the surface barrier above the grade in the ILAW Disposal site. Extensive testing of surfice barriers have been conducted and reported in DOE/RL (1999). The results indicate that wind erosion is not a problem for appropriately designed surface barriers (under the plausible situation of a continued, semi-arid climate, with wind magnitude and direction similar to the measured conditions over the past 50 years). Subsidence of the facility was investigated in the last ILAW performance assessment (Mann 1998a). The results from the analysis concluded there was little effect in the impacts at 10,000 years due to the subsidence of the facility. Earthquakes, should they occur, may impact the engineered elements of the facility (ie., the surface barrier, concrete (if concrete vaults are used), and other layer integrity within the system). It may also lead to subsidence. Nevertheless, the performance of the natural system should remain unchanged. Since the base

$$
\text { A-104 }
$$


analysis case model does not take credit for the engineered systems (except for its potential chemical properties) the estimated impacts due to an earthquake would be no different from the results summarized in section 4.5 .

Finally in considering the impact of flooding the only scenario considered is that of an iceage flood that scrapes away all material down to 20 meters (the depth of the disposal facility), then redeposits the material over the area of the Hanford Site. (The ILAW PA discussed the potential impacts from breaching the current dams on the Columbia River and determined that such postulated events would not lead to any flood waters reaching the elevation of the ILAW disposal site.) The analysis for such a postulated event has been discussed in the IIAW performance assessment (Mann 1998a). The results depend primarily on the ${ }^{126} \mathrm{Sn}$ inventory in the IIAW waste. Since the estimated ${ }^{126} \mathrm{Sn}$ inventory has been reduced, the conclusions from the IIAW PA remain valid and the estimated impacts are less than the all exposure pathways performance objective of $25 \mathrm{mrem}$ (EDE) in a year.

\subsection{Releases to Air}

In previous performance assessments, three radionuclides were considered $\left({ }^{3} \mathrm{H},{ }^{14} \mathrm{C}\right.$, and ${ }^{222} \mathrm{Rn}$ ) as candidates for atmospheric release. Gaseous release from a vitrified waste form is not a very credible scenario because the waste form is assumed to be stable over such a long time. The transport of vapors is governed by Fick's equation, the steady-state solution (Wood 1995) can be expressed as

$$
J=C \sqrt{\lambda D} \exp (-x \sqrt{\lambda D})
$$

where

$$
\begin{aligned}
& J=\text { the flux at the surface }\left(\mathrm{Ci} \mathrm{m}^{-2} \mathrm{y}^{-1}\right) \\
& \mathrm{C}=\text { the concentration of the radionuclide in the ground }\left(\mathrm{Ci} / \mathrm{m}^{3}\right) \\
& \mathrm{X}=\text { the depth of the source }(\mathrm{m}) \\
& \lambda=\text { the decay constant of the radionuclide }\left(=5.64 \times 10^{-2} \mathrm{y}^{-1} \text { for }{ }^{3} \mathrm{H}, 1.21 \times 10^{-4} \mathrm{y}^{-1}\right. \text { for } \\
& \left.D={ }^{14} \mathrm{C} \text { and } 66.2 \mathrm{y}^{-1} \text { for }{ }^{22} \mathrm{Rn}\right) \\
& \mathrm{D}=\text { the diffusion coefficient }\left(=10^{-3} \mathrm{~cm}^{2} / \mathrm{s}=3.14 \mathrm{~m}^{2} / \mathrm{y}\right) .
\end{aligned}
$$

The concentration of the radionuclides in the ground is conservatively assumed to be the maximum inventory in ILAW as defined in Wootan (1999). For ${ }^{3} \mathrm{H}$ the maximum ILAW inventory (2.46x10 $\mathrm{Ci}$ from Wootan 1999) is decayed for 17.7 years beyond site closure (2030). This time represents the balance between the release rate from the waste form and the decay of ${ }^{3} \mathrm{H}$. At lower times the concentration releasod from the waste form depends on the waste form release rate. At times greater than 17.7 years the increase in the release rate is offset by the decay of ${ }^{3} \mathbf{H}$. (At short times the release rate is assumed to be the peak release rate from the concrete vault (11.8 ppm/y) times the time.) The ${ }^{14} \mathrm{C}$ maximum inventory $\left(4.38 \times 10^{3} \mathrm{Ci}\right)$ was taken from Wootan (1999). The ${ }^{222} \mathrm{Rn}$ inventory depends on the ${ }^{206} \mathrm{Ra}$ inventory. At short times the ${ }^{222} \mathrm{Rn}$ inventory is approximately equal to the initial ${ }^{226} \mathrm{R}_{\mathrm{R}}$ inventory. At longer times ${ }^{222} \mathrm{Rn}$ builds in from ${ }^{234} U$ and ${ }^{25} U$ decay chains. At very long times $\left(7750,000\right.$ yeans) the ${ }^{202} \mathrm{Rn}$ inventory is equal to the ${ }^{238} U$ inventory. For these calculations a peak ${ }^{222} R_{n}$ inventory was set equal to the ${ }^{23} \mathrm{U}$ inventory (nominal inventory $=43.8 \mathrm{Ci}$ and upper bound inventory $=3.28 \times 10^{3}$ $\mathrm{Ci}$ from Wootan 1999). The concentration is then calculated to be the total inventory times the peak release rate from the glass and divided by the waste glass volume $\left(1.58 \times 10^{5} \mathrm{~m}^{2}\right)$ associated

$$
\text { A-105 }
$$


with the ILAW waste. For this estimate the concrete disposal concept was selected since it had the highest calculated release rate-(11.8 ppm/y) and the smallest disposal area $\left(3.025 \times 10^{4} \mathrm{~m}^{2}\right)$. Because the top of the waste form is more than 5 meters from the surface, the depth of the source will be taken to be 5 meters for these calculations. The calculated releases to the atmosphere are

$\begin{array}{ll}{ }^{3} \mathrm{H}_{\max }: & 6.8 \times 10^{-11} \mathrm{Ci} \mathrm{m}^{-2} \mathrm{y}^{-1}=2.2 \times 10^{-6} \mathrm{pCi} \mathrm{m}^{-2} \mathrm{~s}^{-1} \\ { }^{14} \mathrm{C}_{\max }: & 6.2 \times 10^{-9} \mathrm{Ci} \mathrm{m}^{-2} \mathrm{y}^{-1}=2.0 \times 10^{-4} \mathrm{pCi} \mathrm{m}^{-2} \mathrm{~s}^{-1} \\ { }^{222} \mathrm{R}_{\mathrm{nam}}: & 5.6 \times 10^{-19} \mathrm{Ci} \mathrm{m}^{-2} \mathrm{y}^{-1}=5.0 \times 10^{-17} \mathrm{pCi} \mathrm{m}^{-2} \mathrm{~s}^{-1} \\ { }^{222} \mathrm{R}_{\mathrm{n}} \mathrm{Rax}: & 3.8 \times 10^{-17} \mathrm{Ci} \mathrm{m}^{-2} \mathrm{y}^{-1}=1.2 \times 10^{-12} \mathrm{pCi} \mathrm{m}^{-2} \mathrm{~s}^{-1}\end{array}$

The small fluxes of ${ }^{222} \mathrm{Rn}$ result from the short half-life of ${ }^{222} \mathrm{Rn}$ and the very deep burial of the waste. Practically all the radon decays before it can reach the surface.

To convert the ${ }^{3} \mathrm{H}_{\max }$ and ${ }^{14} \mathrm{C}_{\max }$ fluxes into a dose, the following equation is used

$$
D=J \text { A }(X / Q) B F
$$

where

$\begin{array}{ll}\mathbf{D}= & \text { the annual inhalation dose } \\ \mathrm{J}= & \text { the flux at the surface } \\ \mathbf{A}= & \text { the area of the facility } \\ (\mathrm{X} / \mathrm{Q})= & \text { normalized integrated exposure } \\ \mathbf{B}= & \text { inhalation rate. } \\ \mathrm{F}= & \text { dose conversion factor }\end{array}$

The values for (X/Q), B, and F are taken from the Performance Assessment for the Disposal of Low-Level Waste in the 200 West Area Burial Grounds (Wood 1994-1). The resulting annual dose is $5.2 \times 10^{-9}$ mrem at 17.7 years for ${ }^{3} \mathrm{H}$ and $1.1 \times 10^{-5}$ mrem (steady state) for ${ }^{14} \mathrm{C}$.

The predicted release of ${ }^{3} \mathrm{H},{ }^{14} \mathrm{C}$, and ${ }^{229} \mathrm{Rn}$ are far below the corresponding performance objectives (10 mrem in a year for ${ }^{3} \mathrm{H}$ and ${ }^{14} \mathrm{C}$ and $20 \mathrm{pCi} \mathrm{m} \mathrm{m}^{-2}$ for ${ }^{222} \mathrm{Rn}$ ).

The calculations for ${ }^{3} \mathrm{H}$ are sensitive to the amount of ${ }^{3} \mathrm{H}$ in the waste form, taken to be 100 percent, and to the time of after facility closure. Because of its short half-life, ${ }^{3} \mathrm{H}$ should decay long before the waste form releases any of the amount that will actually be in the waste form. The best estimate inventory in the waste form is that no tritium will be in the glass.

The calculations for ${ }^{14} \mathrm{C}$ are relatively insensitive to the various parameters. However, the best estimate of ${ }^{14} \mathrm{C}$ in the waste form is zero.

To estimate the release of radon from the soil, radon's diffusivity must be estimated. Harris et al. (1992) aummarized the measurements of gaseous diffusion performance on concrete materials. They concluded that, for dry materihls, diffusion coefficients ranged from $10^{-5}$ to $10^{-3}$ $\mathrm{cm}^{2} / \mathrm{s}\left(10^{-6}\right.$ to $\left.10^{-4} \mathrm{in}^{2} / \mathrm{s}\right)$. The presence of moitture reduces the diffusion coefficient value. Therefore, for these analyses, a value (corresponding to dry conditions) of $1.0 \times 10^{-3} \mathrm{~cm}^{2} / \mathrm{s}(1.6 \times$ $10^{-4} \mathrm{in}^{2} / \mathrm{s}$ ) was used. 


\subsection{RESULTS FOR INADVERDENT INTRUDER SCENARIO}

\subsection{Inadvertent Intruder Scenarios and Data}

Because such intrusion is postulated to be in the future, the nature of the intrusion is illdefined. Thus, selecting values for parameters important in inadvertent intruder scenarios is very difficult. Moreover, uncertainty abounds about the proper values to be used in a given scenario. This performance assessment looks at the groundwater well driller and homesteader scenarios. DOE Order 435.1 provides on specific guidance on the intruder scenario analysis. For this report the specific exposure scenario is define in Rittmann (1999) and is based on previous intruder scenario analyses for the Hanford Site (Wood, 1994, Wood, 1996, and Mann 1998a).

For the groundwater well driller scenario, the most important parameters are the amount of waste taken from the site, the size of the area over which the waste is spread, the depth of mixing, and the physical integrity of the waste.

The amount of waste material taken from the disposal site is assumed to be the average areal density of the waste that varies with each facility model (see Table 5.1) times the area of the bore hole for the well. For this performance assessment, the diameter of the well is assumed to be $0.3 \mathrm{~m} \mathrm{(1} \mathrm{ft).} \mathrm{Although} \mathrm{consistent} \mathrm{with} \mathrm{the} \mathrm{diameters} \mathrm{used} \mathrm{in} \mathrm{earlier} \mathrm{Hanford} \mathrm{Site}$ performance assessments, this value is larger than the range of diameters $(10.2$ to $25.4 \mathrm{~cm}$ [4 to 10 in]) commonly found in local communities and is therefore conservative. The driller model also assumes that only $10 \%$ of the total volume exhumed is waste and the rest is uncontaminated soil from above and below the facility. This assumption effectively dilutes the waste that contributes to the inhalation and ingestion source terms.

The area over which the driller spreads the waste is taken to be $100 \mathrm{~m}^{2}$ (about $1,100 \mathrm{f}^{2}$ ). This value has been historically used in Hanford Site performance assessments. The waste is mixed with uncontaminated soil exhumed from the borehole, and surface soil, to a depth of 15 cm.

The integrity of the waste form becomes important in determining the amount of radionuclides available for inhalation or uptake by plants and animals. For the base case, 90 percent of the radionuclides exhumed is assumed to stay within the waste form (and therefore unavailable).

The worker at the well drilling site is assumed to be exposed 8 hours a day for 5 days. The dose to the worker is the sum of the contributions from inhaling resuspended dust $(0.12 \mathrm{mg} / \mathrm{hr})$, ingesting trace amounts of soil $(100 \mathrm{mg} / \mathrm{day})$, and external exposure at the center of a slab of contaminated soil for $\mathbf{4 0}$ hours. The undecayed dose factors for this scenario can be found in Rittmann (1999).

The most important parameters in the sacond phase of the inadvertent intruder scenario analysis, the homesteader scenario, are the volume of waste exhumed, the area over which it is spread, the depth of mixing, and the integrity of the waste form. For this scenario, the parameters from the all-pathways model also are important. 
In the homesteader scenario the same amount of waste is exhumed as in the driller scenario. Because the waste is assumed to be tilled into the soil, the waste is spread over $200 \mathrm{~m}^{2}$ ( 0.049 acre). In earlier Hanford Site performance assessments, the garden area has been between 500 and $2,500 \mathrm{~m}^{2}$ (0.124 and 0.62 acre). The $200-\mathrm{m}^{2}$ garden was chosen for this performance assessment because the size represents an area large enough to supply a significant portion of a person's vegetable and fruit diet. Household gardens in the vicinity of the Hanford Site range in size from $10 \mathrm{~m}^{2}$ to $1,000 \mathrm{~m}^{2}\left(107 \mathrm{ft}^{2}\right.$ to 0.25 acre) (Napier 1984). The value taken for the depth of the soil mixing is $15 \mathrm{~cm}(5.9 \mathrm{in}$.). This value has been used in other onsite performance assessments and is the typical rooting depth of garden vegetables.

The homesteader is assumed to be exposed for one year. The soil inhalation rate for the homesteader is $573 \mathrm{mg} / \mathrm{yr}$. The incidental ingestion rate is the same as for the driller, 100 $\mathrm{mg} /$ day. The resulting dose factors are displayed in Rittmann (1999).

Table 5.1 Facility Dimensions and Waste Volume Exhumed

\begin{tabular}{|l|l|l|}
\hline & Remote Handled Trench $^{2}$ & Concrete Vault \\
\hline Waste Package Dimensions $(\mathrm{m})^{1}$ & $1.4 \times 1.4 \times 1.2$ & $1.4 \times 1.4 \times 1.2$ \\
\hline Facility Dimensions $(\mathrm{m})$ & $200.0 \times 20.0$ & $18.3 \times 21.0$ \\
\hline Layers of Waste Packages & 4 & 6 \\
\hline Packages per Layer & 1584 & 168 \\
\hline Surface Area $\left(\mathrm{m}^{2}\right)$ & 4000 & 384 \\
\hline Waste Volume $\left(\mathrm{m}^{3}\right)$ & 14900 & 2380 \\
\hline Areal Density $\left(\mathrm{m}^{3} / \mathrm{m}^{2}\right)$ & 3.73 & 6.20 \\
\hline Volume Waste Exhumed $\left(\mathrm{m}^{3}\right)$ & 0.272 & 0.453 \\
\hline
\end{tabular}

1 The waste package is $1.4 \mathrm{~m}$ high but only filled $85 \%$ full so it is treated here as $1.2 \mathrm{~m}$ high.

${ }^{2}$ Only the central portion of the trench is considered. If the fringe regions were averaged in then the areal density and volume exhumed would be lower.

${ }^{3}$ The number of packages in the bottom layer in the trench is used as an approximation for the number of packages above the central region in the upper layers.

\subsection{Inadvertent Intruder Results}

The results of the inadvertent intruder analysis, at the compliance date of 2530 , are shown in Table 5.2. The acute dose (driller scenario) to an inadvertent intruder in the RHT facility is plotted vs. time in Figure 5.1. The chronic dose (homesteader scenario) is shown similarly in Figure 5.2.

Table 5.2 Doses at Compliance Date (500 Years after Facility Closure)

\begin{tabular}{|l|l|l|}
\hline & RHT & Vault \\
\hline Acute Dose (mrem) & $8.8 \times 10^{-1}$ & 1.5 \\
\hline Chronic Dose (mrem) & $2.7 \times 10^{!}$ & $4.4 \times 10^{1}$ \\
\hline
\end{tabular}


Figure S.1 Acute Dose at RHT

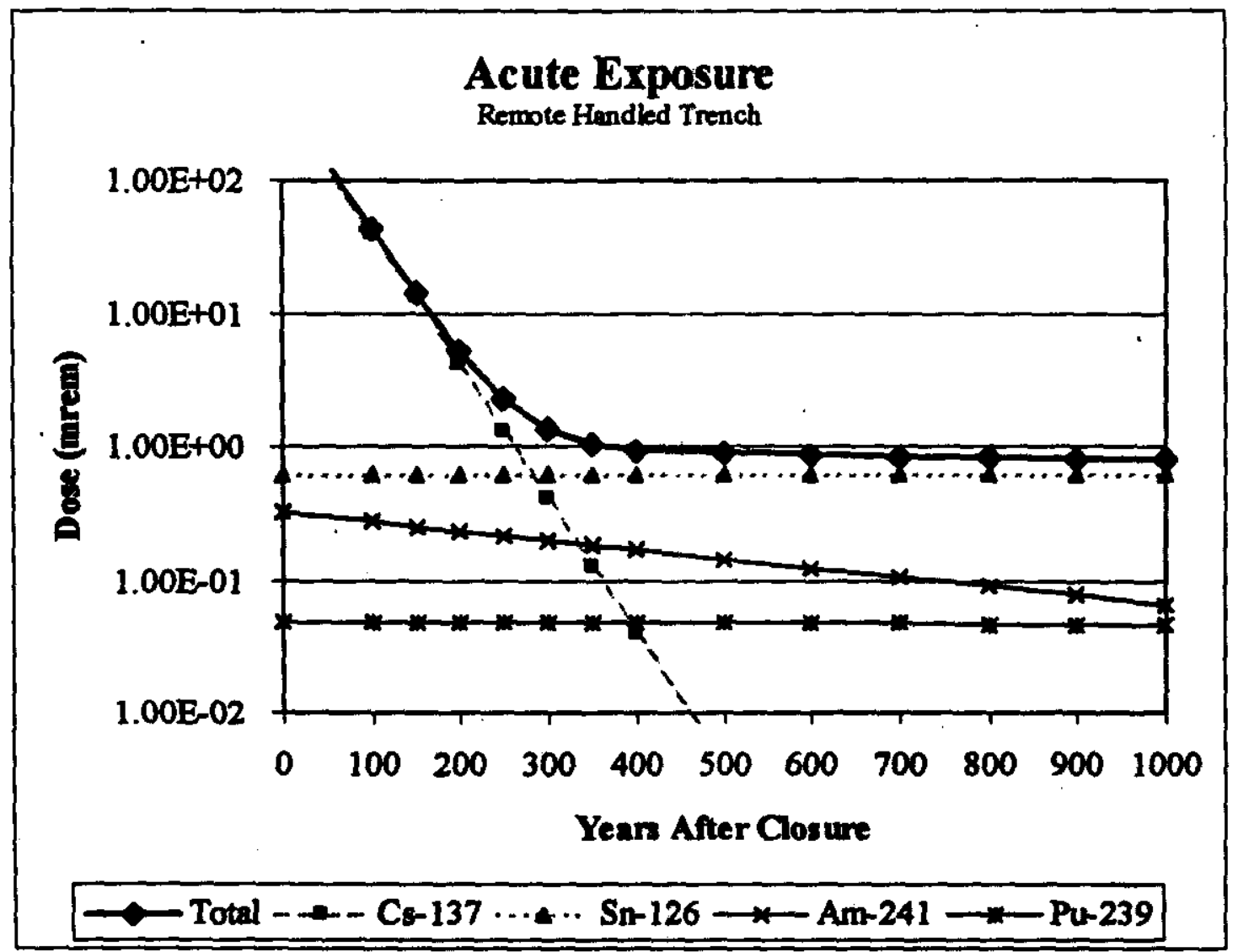

The estimated acute exposure dose at 500 years after facility closure (time of compliance) is 0.9 mrem. The major contributor to the acule dose is ${ }^{126}$. Sn that contributes approximately $71 \%$ of the dose. ${ }^{241} \mathrm{Am}$ and ${ }^{239} \mathrm{Pu}$ provide contributions of 17 and $5 \%$, respectively, to the exposure dose. The estimated contimuous exposure dose at 500 years after ficility cloaure (time of compliance) is 27 mrem in a year. For the continuous exposure scentrio ${ }^{241} \mathrm{Am},{ }^{126} \mathrm{Sn}$ and ${ }^{239} \mathrm{Pu}$ are estimated to provide 39, 26, and 23\%, respectively, to the total dose. As discussed in section 3.2 approximately $36 \%$ of the ${ }^{126} \mathrm{Sn}, 5.5 \%$ of the ${ }^{23 \%} \mathrm{Pu}$, and $10 \%$ of the ${ }^{241} \mathrm{Am}$ of the initial tank inventories remain in the waste affer processing (Kirkbride 1999). These numbers may change when BNFL specific flowsheet information is obtained.

These estimates are sensitive to the perameters assumed for the sconario. For example the new scenario has a garden area of $200 \mathrm{~m}^{2}$ versus the $2500 \mathrm{~m}^{2}$ area used in the last ILAW performance assessment. This increases the dose by a factor of 12.5. Similarly, if the well diameter were decreased to a $0.23 \mathrm{~m}$ ( 9 in) then the corresponding doses would be decreased by approximatley a factor of 2 . 
Figure 5.2 Chronic Dose at RHT

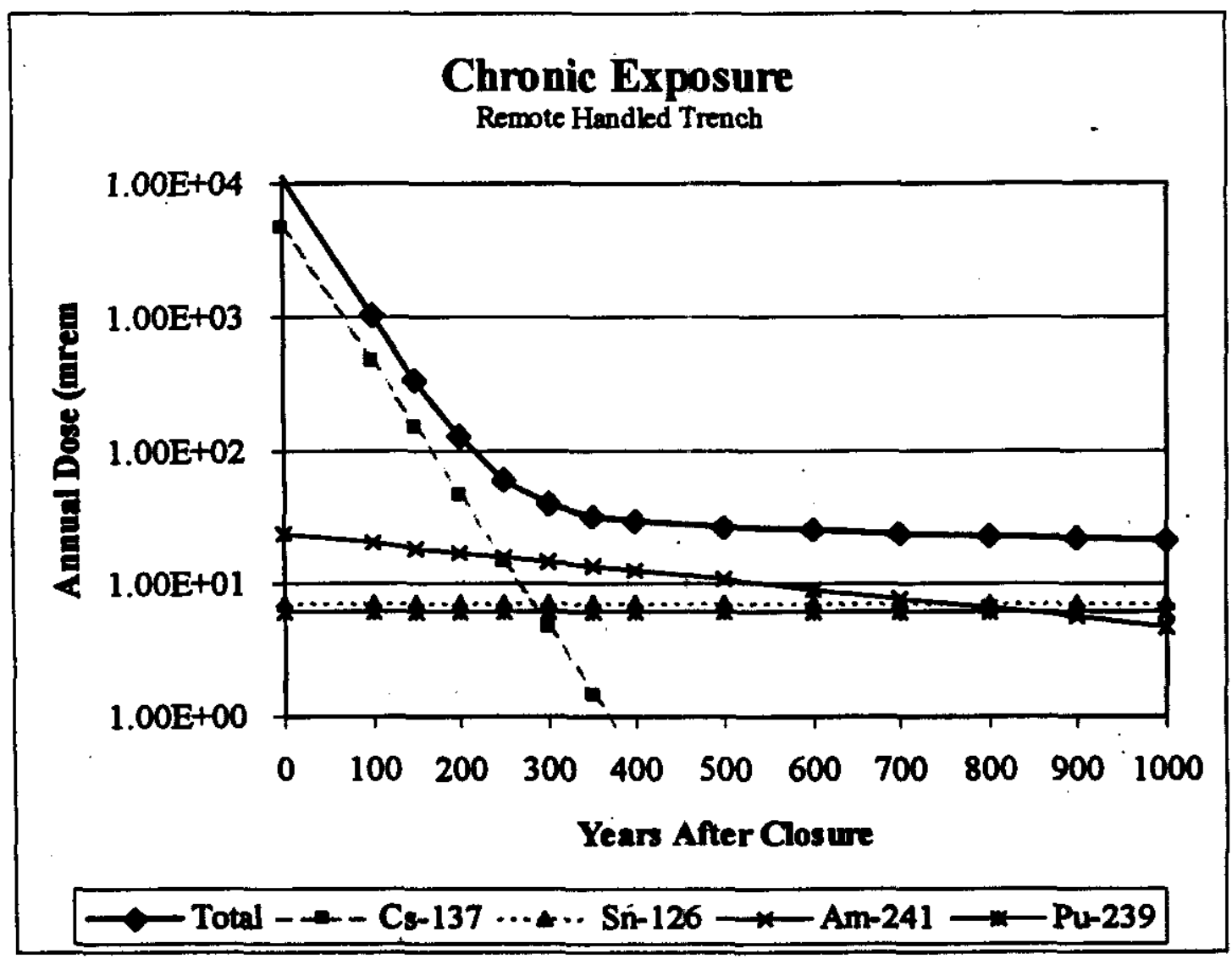

To estimate the uncertainty in the inadvertent intruder estimated dose to uncertainties in the inventory the maximum batch concentrations listed in Table 3.1 were used. Specifically, the maximum batch concentrations for ${ }^{126} \mathrm{Sn},{ }^{239} \mathrm{Pu}_{1}$ and ${ }^{241} \mathrm{Am}$ were used to estimate the impact to the intruder dose estimates. The maximum batch concentration reflects the tank to tank variation in inventory for each radiomuclide. The ratio of the maximum batch concentration to the average batch concentration for ${ }^{126} \mathrm{Sn},{ }^{209} \mathrm{Pu}$, and ${ }^{241} \mathrm{Am}$ are 9.7, 25, and 4.9, respectively.

The RH trench has waste packages stacked 4 layers high. If one of the waste packages in a layer had the maximum batch concentration and the remaining throe packages above and/or below had average batch concentrations, then the estimated acute exposure would be approximately 3 mrem and the estimated continuous exposure would be approximately 105 mrem in a year. This is higher than the performance objective of 100 mrem in a year.

These estimated impacts can be mitigated through operational controls based on projected container inventories. Such operational controls will be better defined as the project matures. 


\subsection{PERFORMANCE EVALUATION}

This chapter compares the estimated impacts covered in Chapters 4 and 5 with the performance objectives established in Chapter 1. Section 6.1 summarizes the comparison of the base case impacts with respect to the performance objectives. Section 6.2 discusses the sensitivity of these results to the key assumptions and uncertainties in these analyses. Finally, section 6.3 provides the conclusions from this white paper analysis.

\subsection{Comparison of Estimated Impacts to Performance}

This section compares the estimated impacts to the performance objectives for each area of protection cited in Section 1.3:

- Protection of the general public

- Protection of the inadvertent intruder

- Protection of groundwater resources

- Protection of surface water resources

- Protection of air resources.

The inadvertent intruder estimated impacts depend on inventory and facility design, and can be mitigated to some extent operationally. The estimated impacts for the other performance objectives (except for air resources) depend on inventory, waste form release, and groundwater flow.

\subsubsection{Protection of General Public}

Table 6.1 compares the performance objectives for protecting the general public with the results from the base analysis case. The estimated all-pathways doses are significantly lower than the performance objectives during the first 10,000 years.

The performance measures (i.e. impacts) over the first 10,000 years after facility closure (2030) are not estimated to exceed the value of the performance objectives at any time.

Table 6.1 Comparison of Estimated Impacts with Performance Objectives for Protecting the Public. The DOE time of compliance is 1,000 years. The point of compliance is a well 100 meters downgradient of the facility

\begin{tabular}{|l|l|l|l|l|}
\hline Performance Measure & $\begin{array}{l}\text { Performance } \\
\text { Objective }\end{array}$ & $\begin{array}{l}\text { Estimated Impact } \\
\text { at 1,000 y }\end{array}$ & $\begin{array}{l}\text { Estimated Impact at 10,000 y } \\
1998 \text { ILAW PA Updated Results }\end{array}$ \\
\hline All-pathways [mrem in a y] & 25.0 & 0.0061 & 6.4 & 0.72 \\
\hline
\end{tabular}

\subsubsection{Protection of Inadvertent Intruders}

Table 6.2 compares the estimated impacts to the performance objectives for protecting the inadvertent intruder. The time of complisnce starts at 500 years after closure. The acute exposure performance objective is met by a fictor greater than 500 for the remote handled 
trench. ${ }^{126} \mathrm{Sn}$ is the most important radionuclide. The continuous exposure performance objective is met by a factor of approximately 4 for the base analysis case. ${ }^{241} \mathrm{Am},{ }^{126} \mathrm{Sn}$ and ${ }^{239} \mathrm{Pu}$ are the major contributors. These results are similar in magnitude as those found in the ILAW PA (Mann 1998a).

Table 6.2 Comparison of Estimated Impacts with Performance Objectives for Protecting the Inadvertent Intruder. The time of compliance starts at 500 years

\begin{tabular}{|l|l|l|l|}
\hline Performance Measure & $\begin{array}{l}\text { Performance } \\
\text { Objective }\end{array}$ & \multicolumn{2}{|l|}{$\begin{array}{l}\text { Estimated Impact } \\
1998 \text { ILAW PA Updated Results }\end{array}$} \\
\hline Acute exposure [mrem] & 500.0 & 5.5 & 0.9 \\
\hline Continuous exposure [mrem in a year] & 100.0 & 27.5 & 27. \\
\hline
\end{tabular}

The estimated impacts for the inadvertent intruder can be mitigated through operational controls based on projected container inventories. Such operational controls will be better defined as the project matures.

\subsubsection{Protection of Groundwater Resources}

Table 6.3 compares the estimated impacts to the performance objectives for protecting the groundwater resources. At the DOE time of compliance (1,000 years) and the point of compliance (at a well 100 meters downgradient of the disposal facility), the groundwater impacts are not significant. At 10,000 years the estimated impact is a factor of 24 less than the performance objectives for beta/photon emitters and a factor of 120 less than the performance objectives for the alpha-emitting radionuclides for the base analysis case. The concentration of radium is insignificant. The most important drivers are the inventories of technetium, iodine, neptunium, and uranium, the release rate from the waste form, and the amount of mixing in the aquifer. Retardation of uranium isotopes as they migrate through the natural vadose zone is important in achieving the alpha-emitting radionuclides performance measure. The anticipated retardation of the uranium isotopes through any concrete associated with the engineered facility has not been included in these estimates.

Table 6.3 Comparison of Estimated Impacts with Performance Objectives for Protecting Groundwater Resources. The DOE time of compliance is 1,000 years. The point of compliance is a well 100 meters downgradient of the facility.

\begin{tabular}{|l|l|l|l|l|}
\hline Performance Measure & $\begin{array}{l}\text { Performance } \\
\text { Objective }\end{array}$ & $\begin{array}{l}\text { Estimnted Impact } \\
\text { at } 1,000 \mathrm{y}\end{array}$ & $\begin{array}{l}\text { Estimated Impact at 10,000 y } \\
1998 \text { ILAW PA Updated Results }\end{array}$ \\
\hline $\begin{array}{l}\text { Beta/Photon Emitters } \\
\text { [mrem in a y] }\end{array}$ & 4. & 0.0017 & 2.0 & 0.17 \\
\hline $\begin{array}{l}\text { Alpha-emitting } \\
\text { radionuclides [pCi/L] }\end{array}$ & 15. & $4.2 \times 10^{-14}$ & 1.7 & 0.13 \\
\hline $\mathrm{Ra}$ [pCi/L] & 5. & 0.0 & $<0.001$ & 0.0 \\
\hline
\end{tabular}




\subsubsection{Protection of Surface Water Resources}

Table 6.4 compares of the estimated impacts to the performance objectives for protecting the surface water resources. The DOE time of compliance is 1,000 years and the point of compliance is at a well intercepting the groundwater just before it mixes with the Columbia River. The estimated impacts are approximately three orders of magnitude lower than the performance objectives. The estimated impacts at a well just before the river are conservative with respect to the quality of the river water. In addition, these estimates do not include dilution due to bank storage effects.

Table 6.4 Comparison of Estimated Impacts with Performance Objectives for Protecting Surface Water Resources. The DOE time of compliance is 1,000 years. The point of compliance is a well intercepting the groundwater prior to entering the Columbia River

\begin{tabular}{|l|l|l|l|l|}
\hline Performance Measure & $\begin{array}{l}\text { Performance } \\
\text { Objective }\end{array}$ & $\begin{array}{l}\text { Estimated Impact } \\
\text { at 1,000 y }\end{array}$ & $\begin{array}{l}\text { Estimated Impact at 10,000 y } \\
1998 \text { ILAW PA Updated Results }\end{array}$ \\
\hline $\begin{array}{l}\text { Beta/Photon Emitters } \\
\text { [mrem in a y] }\end{array}$ & 1.0 & $1.4 \times 10^{-1}$ & 0.070 & 0.014 \\
\hline Alpha Emitters [pCi/L] & 15.0 & $6.8 \times 10^{-16}$ & 0.058 & 0.011 \\
\hline $\mathrm{Ra}[\mathrm{pCi} / \mathrm{L}]$ & 30.3 & 0.0 & $<0.001$ & 0.0 \\
\hline
\end{tabular}

\subsubsection{Protection of Air Resources}

Table 6.5 compares the estimated impacts to the performance objectives for protecting air resources. The DOE time of compliance is 1,000 years and the point of compliance is just above the disposal facility. The estimated impacts are over three orders of magnitude lower than the performance objectives.

Table 6.5 Comparison of Estimated Impacts with Performance Objectives for Protecting Air Resources. The DOE time of compliance is 1,000 years. The point of compliance is just above the disposal facility.

\begin{tabular}{|l|l|l|l|}
\hline Performance Measure & $\begin{array}{l}\text { Performance } \\
\text { Objective }\end{array}$ & $\begin{array}{l}\text { Estimated Impact at l,000 y } \\
1998 \text { ILAW PA }\end{array}$ Updated Results \\
\hline Radon [pCi m $\mathrm{m}^{-2}$ ] & 20.0 & 0.001 & 0.001 \\
\hline $\begin{array}{l}\text { Other radionuclides }{ }^{3} \mathrm{H} \\
\text { and }{ }^{14} \mathrm{C} \text { [mrem in a y] }\end{array}$ & 10.0 & $<10^{-7}$ & 0.0 \\
\hline
\end{tabular}

\subsubsection{Summary}

All of the estimated effects easily meet the performance objectives set out in Section 1.3 for the RH trench base analysis case. The extimated all-pathways dose, beta/photon drinking water dose, and the concentration of alpha-emitting radionuclides in groundwater are more than a factor of 200 lower than the corresponding performance objective at 10,000 years after facility closure (2030). The inadvertent intruder continuous exposure doses are estimated to be a factor of approximately 4 below the performance objective.

$$
\text { A- } 113
$$




\subsection{Performance Sensitivity to Key Parameter Uncertainties}

The key parameters impacting the performance of the disposal system are the inventory, waste form performance, and disposal facility related parameters. The impacts of these uncertainties have been explored to some extent with the calculations provided in this report. Additional insight is provided from the results from the ILAW PA (Mann 1998a).

The inventory report (Wootan 1999) provides an upper bound estimate for the ILAW inventory. Table 3.1 provides the upper bound inventory in a given package. The primary contributors to the groundwater scenarios are radionuclides with assigned values of $K_{d}=0 \mathrm{~mL} / \mathrm{g}$ and $\mathrm{K}_{\delta}=0.6 \mathrm{~mL} / \mathrm{g}$ (see Table 3.4 ). Table 6.6 provides the estimated impacts of inventory uncertainty for selected performance objectives for protection of the groundwater. These impacts are estimated by normalizing the upper bound package concentrations to the base analysis case, $\mathrm{RH}$ trench concept results.

Table 6.6 Impact of Inventory Uncertainty on Groundwater Scenarios at 10,000 Years After Facility Closure

\begin{tabular}{|l|l|l|l|}
\hline Inventory Case & $\begin{array}{l}\text { All Pathways } \\
\text { Dose } \\
\text { (mrem/y) }\end{array}$ & $\begin{array}{l}\text { Beta-Photon } \\
\text { Drinking Water Dose } \\
\text { (mrem/y) }\end{array}$ & $\begin{array}{l}\text { Alpha Emitter } \\
\text { Radionuclide } \\
\text { Concentration (pCi/L) }\end{array}$ \\
\hline Performance Objective & 25.0 & 4 & 15 \\
\hline Base Case & 0.72 & 0.17 & 0.13 \\
\hline Upper Bound Inventory & 3.8 & 0.81 & 0.70 \\
\hline
\end{tabular}

For the intruder scenario, ${ }^{126} \mathrm{Sn}$ is the primary contributor to the dose for the acute exposure scenario. ${ }^{126} \mathrm{Sg},{ }^{239} \mathrm{Pu}$, and ${ }^{241} \mathrm{Am}$ are estimated to have comparable contributions to the dose for the continuous exposire scenario. (Sr and $\mathrm{Cs}$ are limited by the Phase 1 contract and NRC requirements). Using the maximum batch concentration in one waste package layer and the average batch concentration in the waste packages immediately above/below for these three isotopes from Table 3.1 yields the following estimated impacts (see Table 6.7) for the RH.trench.

Table 6.7 Impact of Inventory Uncertainty on Inadvertent Intruder Scenarios

\begin{tabular}{|l|l|l|}
\hline Inventory Case & $\begin{array}{l}\text { Acute Exposure } \\
\text { (mrem) }\end{array}$ & $\begin{array}{l}\text { Continuous Exposure } \\
\text { (mrem in a year) }\end{array}$ \\
\hline Performance Objective & 500 & 100 \\
\hline Base Case & 0.9 & 27 \\
\hline Maximum Batch Concentration (in one Layer) & 3 & 105 \\
\hline
\end{tabular}

The acute exposure performance objective is still met for this higher inventory of ${ }^{126} \mathrm{Sn}$, ${ }^{239} \mathrm{Pu}$, and ${ }^{241} \mathrm{Am}$. However, the continuous exposure performance objective would barely be exceeded if one waste package with the maximum batch inventory were stacked vertically with three other packages having the average batch concentrations.

Since ${ }^{126} \mathrm{Sn},{ }^{239} \mathrm{Pu}$, and ${ }^{241} \mathrm{Am}$ are the major contributors to the continuous exposure for the inadvertent intruder, the number of waste packages that can be stacked vertically depend s on the concentrations of these radionuclides in these vertical stack. Table 6.7 provides the impacts

$$
\text { A-114 }
$$


for waste packages stacked 4 high. Based on these results the stacking height is limited to fewer than 4 packages if one waste package has the maximum batch concentration and the remaining packages have average package concentrations. This can be accomplished operationally by placing these packages at the edges of the facility. This condition can also be avoided by appropriate operations planning or additional separations.

The uncertainty in the disposal facility is associated with the different concepts (RH trench versus concrete vault), and the recharge rate. These results for the groundwater scenarios are summarized in Table 6.8.

Table 6.8 Impact of Disposal Facility Uncertainty on Groundwater Scenarios

\begin{tabular}{|l|l|l|l|}
\hline & $\begin{array}{l}\text { All Pathways Dose } \\
(\mathrm{mrem} / \mathrm{y})\end{array}$ & $\begin{array}{l}\text { Beta-Photon } \\
\text { Drinking Water } \\
\text { Dose (mrem/y) }\end{array}$ & $\begin{array}{l}\text { Alphe Emitter } \\
\text { Radionuclide } \\
\text { Concentration (pCi/L) }\end{array}$ \\
\hline Perforal Facility Case & & 4 & 15 \\
\hline Base Case & 25.0 & 0.17 & 0.13 \\
\hline Recharge $=0.9 \mathrm{~mm} / \mathrm{y}$ & 0.042 & 0.012 & $5.7 \times 10^{-14}$ \\
\hline Concrete Vault & 2.7 & 0.29 & 1.9 \\
\hline
\end{tabular}

\subsection{Uncertainties Regarding Glass Performance}

The calculations and long-term performance results discussed in previous sections of this document are based on a detailed analysis of the release behavior of LAWABP1 glass.

However, it is a virtual certainty that BNFL, Inc. will not produce ILAW glasses with this specific composition. Consequently, it is important to asseas the likelihood that the glass waste forms that will be produced by BNFL, Inc. will have long-term durability characteristics approximating that of LAWABP1 glass. Unfortunately, it is impossible to do so quantitatively because 1) specific glass formulations for IIAW disposal have not as yet been selected by BNFL, Inc. for production, and 2) insufficient experimental data are available to perform STORM simulations with the glasses, even if the compositions themselves were available.

As an intermediate step, the relative performance of BNFL, Inc. type glass compositions can be compared in highly accelerated laboratory tests designed to elucidate the long-term behavior of the materials on a practicable time scale (McGrail, et al. 1999b). Two experimental methods are principally used for this purpose (McGrail et al. 1998b), the vapor hydration test (VHT) and the pressurized unsaturated flow (PUF) test. Briefly, in the VHT, monolithic samples are exposed to saturated water vapor at elevated temperatures (typically $100^{\circ} \mathrm{C}$ to $300^{\circ} \mathrm{C}$ ) in a sealed vessel. This environment greatly accelerates the progression of glass corrosion by water and can result in the formation of alteration phases. The principal uses of the test are 1) as a screening tool to quickly determine if a glass is likely to corrode at an extreme rate, 2) as a convenient means of generating alteration phases for analysis within a short period, and 3) for a measure of the alteration rate at elevated temperatures. In contrast, the patented PUF test is an open-system test where water flows through a bed of coarsely-ground glass under conditions of partial hydraulic saturation (McGrail et al. 1997). A computer control syatem stores test data to disk from several thermocouples, pressure sensors, inline sensors for effluent $\mathrm{pH}$ and conductivity, and column weight from an electronic strain gauge to accurately track water mass

\footnotetext{
"Patent *5974859, "Method and Apparatus for Measuring Couplod Flow and Reaction Proceases," 1999. $A-115$
} 
balance and saturation level. Experience in running PUF tests with a number of different ILAW glass compositions has proven the method to be highly effective in 1) accelerating the progression of the glass corrosion process into the so-called "Stage 3" regime representative of longer-term corrosion behavior, and 2) detecting glasses that are unstable with respect to secondary phases that form as a result of the glass/water reaction processes during the test.

Figure 6.1 Radial Distribution Plot of $200^{\circ} \mathrm{C}$ VHT Corrosion Rates for HLP Series of ILAW Glasses. Radial coordinates are $\log _{10}$ corrosion rate, $g /\left(\mathrm{m}^{2} \cdot \mathrm{d}\right)$

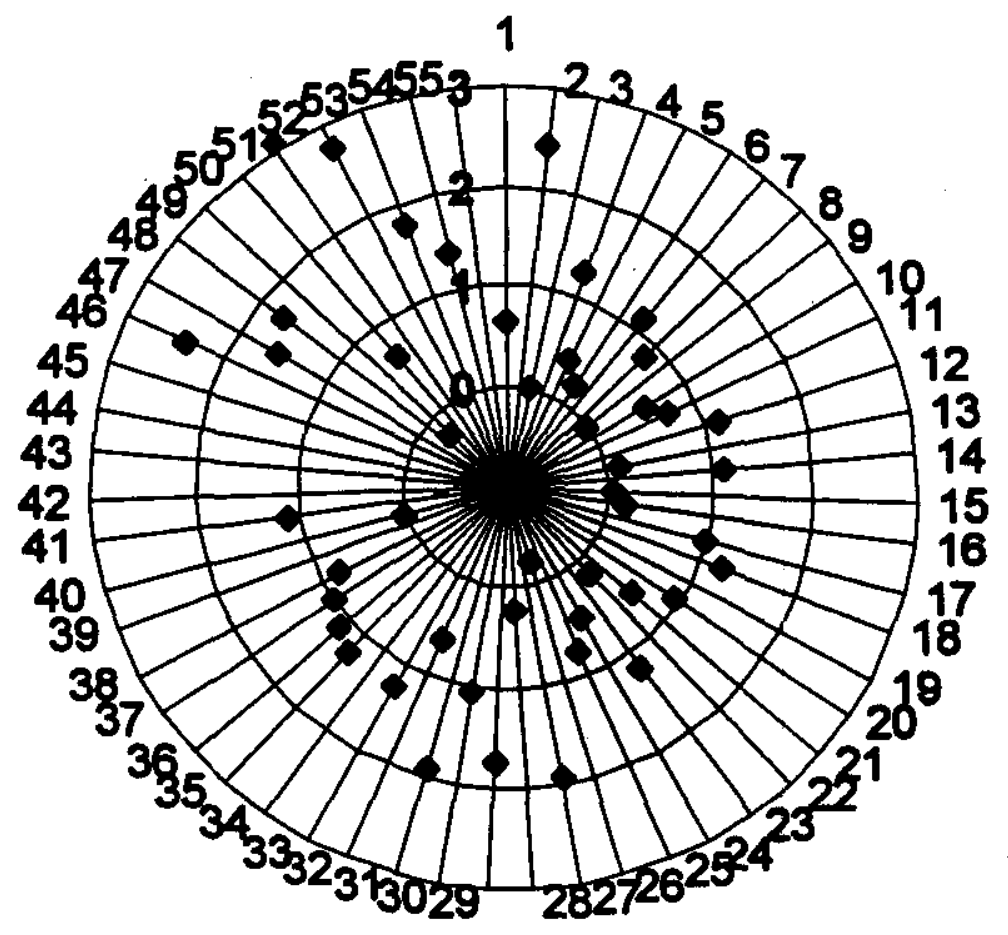

A matrix of 56 glass compositions was subjected to VHTs at $200^{\circ} \mathrm{C}$ for sufficiently long periods of time to obtain a statistically meaningful measure of the glass corrosion rate (Vienna et al. 2000). The glasses varied the concentrations of $\mathrm{SiO}_{2}, \mathrm{Al}_{2} \mathrm{O}_{3}, \mathrm{~B}_{2} \mathrm{O}_{3}, \mathrm{Fe}_{2} \mathrm{O}_{3}, \mathrm{TiO}_{2}, \mathrm{ZnO}, \mathrm{ZrO}$, $\mathrm{MgO}$, and $\mathrm{Na}_{2} \mathrm{O}$ across a wide composition range that covers, with high probability, the expected processing composition range of BNFL, Inc. The test matrix was designed in collaboration with staff at the Catholic University of America who is principally responsible for ILAW waste form development to ensure that the selected components and ranges were relevant to glasses that are under current development. For details on the specific glass compositions involved, please see Vienna et al. (2000). In Figure 6.1, we plot the logarithm of the measured VHT corrosion rate for 50 of the glasses (note that results for 6 of the test glasses were not yet available). Immediately obvious from the plot is that a large fraction of the test glasses have corrosion rates less than $10 \mathrm{~g} /\left(\mathrm{m}^{2} \mathrm{~d}\right)$. This result was quite upexpected because the aggressive, high-temperature conditions of the VHT were anticipated to produce high corrosion rates for a significantly larger fraction of the test glasses.

To more quantitatively analyze the results, the VHT corrosion rate data have been replotted in the form of a cumulative distribution function as shown in the Figure 6.2 for glasses studied under the Tank Focus Area (TFA). The measured $200^{\circ} \mathrm{C} \mathrm{VHT} \mathrm{corrosion} \mathrm{rate} \mathrm{for}$ LAWABP1 glass is $4.4 \mathrm{~g} /\left(\mathrm{m}^{2} \mathrm{~d}\right)$ and the corresponding data point is highlighted in Figure 6.2.

$$
\text { A- } 116
$$


This glass is near the midpoint of the distribution (half of the data set have higher rate and half lower) of $7.2 \mathrm{~g} /\left(\mathrm{m}^{2} \mathrm{~d}\right)$. A full $80 \%$ of the tested glasses have $200^{\circ} \mathrm{C}$ VHT corrosion rates less than $30 \mathrm{~g} /\left(\mathrm{m}^{2} \mathrm{~d}\right)$. This is about 8 times faster than the VHT rate for LAWABP1 glass. However, a glass reacting 8 times faster than LAWABP1 would still fall well within the margin of safety available to meet groundwater pathway performance objectives, based on the data in Table 6.8.

Figure 6.2 Cumulative Distribution Plot of $200^{\circ} \mathrm{C}$ VHT Corrosion Rates for HILP Series of ILAW Glasses.

Approximately $80 \%$ of the test glasses have VHT corrosion rates at $200^{\circ} \mathrm{C}$ less than $30 \mathrm{~g} /\left(\mathrm{m}^{2} \mathrm{~d}\right)$. The data were fit to a 3-parameter logistic function of the form $y=a /\left[1+\left(x / x_{0}\right)^{b}\right]$.

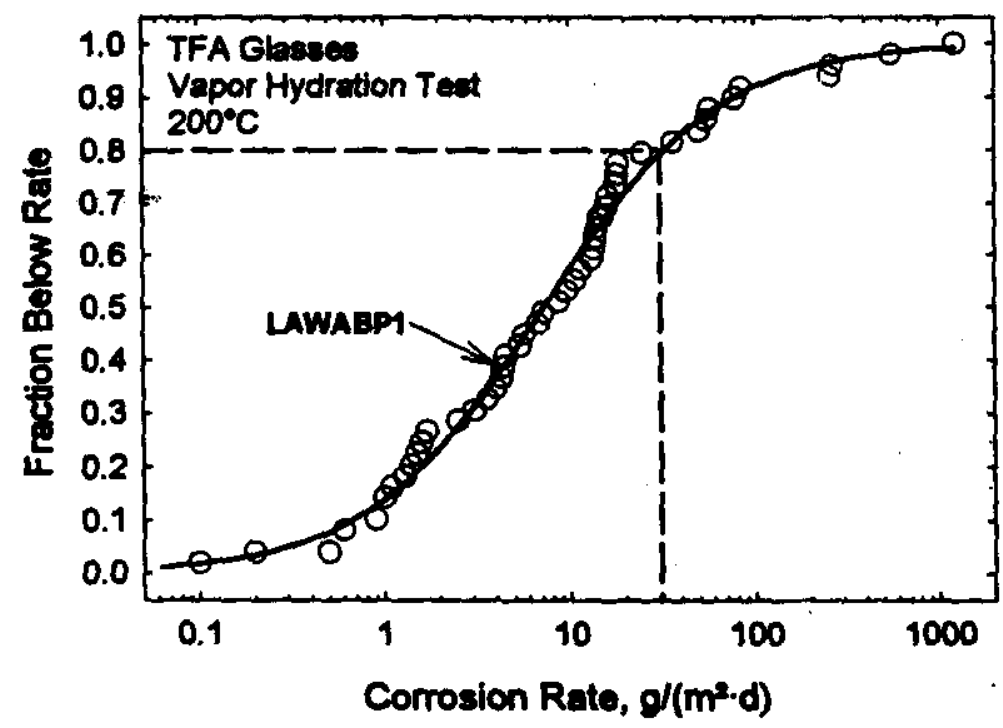

Figure 6.3 Comparison of Glass Corrosion Rate in PUF Tests at $99^{\circ} \mathrm{C}$ and $2 \mathrm{~mL} / \mathrm{d}$

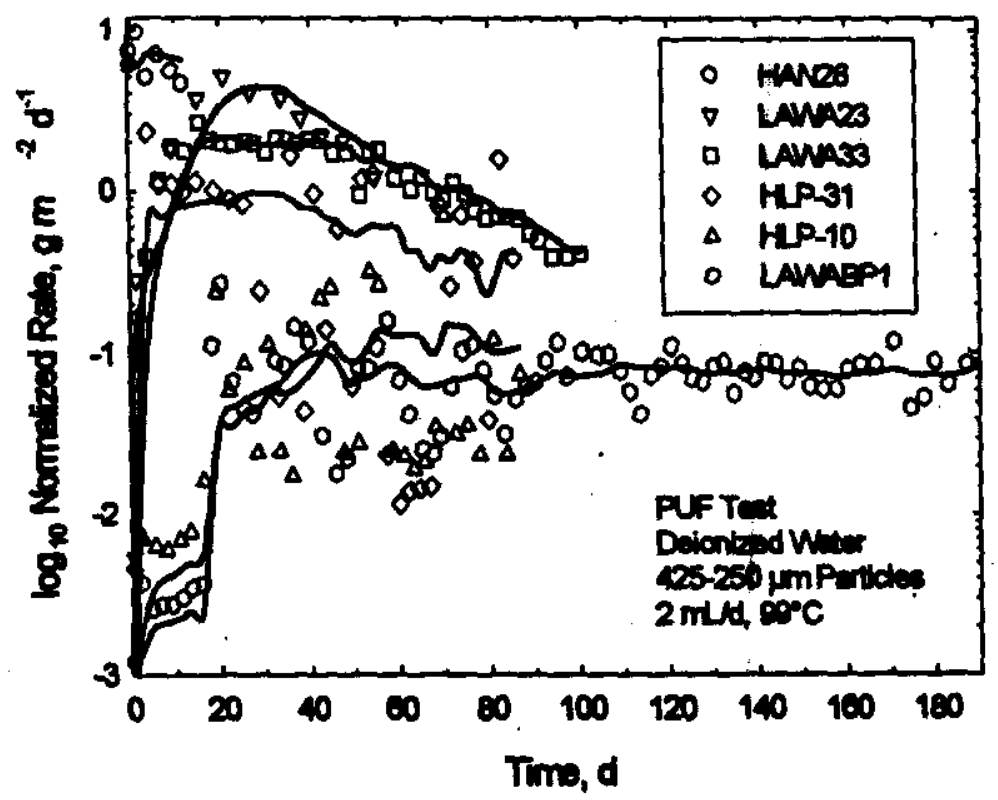




\section{DOE/ORP-2000-19, REV. 0 \\ Reference: DOE/ORP-2000-07, REV. 0}

Because of the much greater complexity of the hardware and support equipment, fewer experimental data exist in terms of compositions tested via the PUF system. The latest available data relevant to BNFL, Inc. compositions are shown in Figure 6.3. The lines on the figure were computed by using a 4-point moving average for the HAN28, LAWA23, and LAWA33 glasses and a 10-point moving average for the HLP-10, HLP-31, and LAWABP1 glasses. A comparison of the peak dissolution rate observed in PUF tests versus the dissolution rate estimated in VHTs at $200^{\circ} \mathrm{C}$ is plotted in Figure 6.4. The peak dissolution rate was used from the PUF tests because for the glasses with high dissolution rates, the apparent corrosion decreases with time as the total unreacted glass surface area decreases, and this is not taken into account in the corrosion rate calculation. The results suggest a good correlation between the VHT and PUF test results $\left(\mathbf{R}^{2}=\right.$ 0.91 ). Similar secondary phases formed in both types of tests, which is probably why a correlation exists between the results. Although the available data are obviously still very limited, the VHT appears to provide a good indicator of glass performance in the PUF test, and both accelerated tests are providing a consistent picture about the long-term performance of ILAW glasses as a function of glass composition. Pending confirmation of these results as additional PUF test data are developed on more ILAW glasses, it appears to be a virtual certainty that glasses can be formulated and manufactured that will meet performance objectives for disposal of low-activity tank wastes.

Figure 6.4 Comparison of Glass Corrosion Rate in PUF Tests at $99^{\circ} \mathrm{C}$ and VHT Tests at $200^{\circ} \mathrm{C}$. Solid line is the regressed fit and the dashed lines are the $95 \%$ confidence interval.

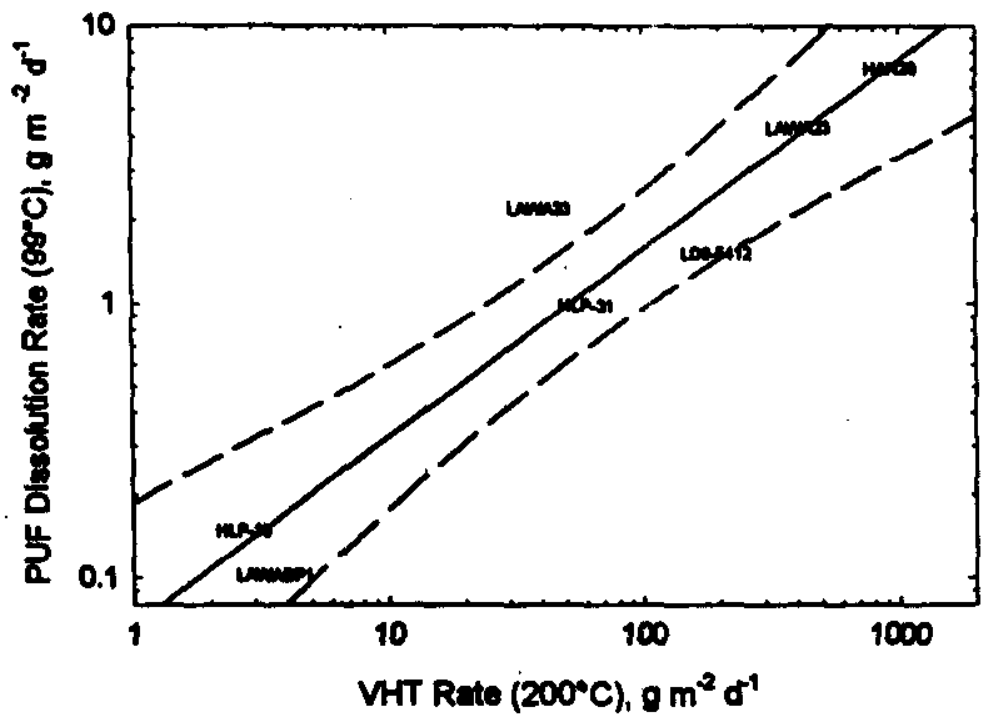




\subsection{Summary of the Impact of Differences Between the 1998 I.AW PA and This Document}

Of the three types of scenarios (groundwater, air, and inadvertent intruder) studied in the 1998 ILAW PA (Mann 1998) and this document, only the results for the groundwater scenario are significantly different. There are five major differences in inputs between the 1998 ILAW PA and this document that affect the peak values of impact parameters for scenarios that contaminate groundwater:

Time of compliance

Inventory of mobile constituents

Disposal facility design

Waste Form performance

Groundwater dilution

Other new data (such as recharge rates, geochemistry, and hydrology) affect the time that the peak occurs or affect the impact parameters through one of the last four inputs cited above.

The 1998 IIAW PA used 10,000 years as the time of compliance. Because of new DOE guidance, the present time of compliance is 1,000 years. However, because of the low travel time in the vadose zone, even the mobile constituents do not reach the groundwater in any significant quantity in only 1,000 years.

To make comparisons with the 1998 ILAW PA easier, Table 6.9 summarizes the differences in impact parameters at 10,000 years.

Table 6.9 Effect of Updated Model Inputs on the Estimated Beta/Gamma Drinking Water Dose at 10,000 Years. (1998 ILAW PA estimated this dose as $2.0 \mathrm{mrem} / \mathrm{yr}$.)

\begin{tabular}{|l|r|r|}
\hline Updated Model Input & \multicolumn{3}{|c|}{ Beta/Gamma Drinking Water Dose } \\
\cline { 2 - 3 } & White Pagt (mrem/yr) & Ratio to 1998 ILAW PA \\
\hline Facility Design & 1.18 & 0.59 \\
\hline Tc Inventory & 0.52 & 0.26 \\
\hline Other Mobile Contaminants (1) & 3.16 & 1.58 \\
\hline Waste Form Release Rate & 7.20 & 3.6 \\
\hline Groundwater Dilution & 0.196 & 0.098 \\
\hline All Inputs & 0.170 & 0.085 \\
\hline
\end{tabular}

(1) based on updated $\mathrm{K}_{d}$ values for $\mathrm{Se}, \mathrm{I}$, and $\mathrm{Np}$.

The impact at 10,000 years of changing the inventory of the mobile constituents is a factor of 0.41 . This results because of two chinges, the change in the inventory of ${ }^{99} \mathrm{Tc}$ (the most important radionuclides in either analysis) and the change of inventories of other mobile radiomuclides. The 1998 ILAW PA assumed that $80 \%$ of the Tc in tanks would end up in ILAW, while the present documents assumes based on the contract between BNFL, Inc. and DOE (DOE/BNFL 1998) that only $20 \%$ of the Tc in tanks will go into IIAW. The remaining slight different in Tc inventory results from a small change in tank inventory. 


\section{DOE/ORP-2000-19, REV. 0 \\ Refenc: DOE/ORP-2000-07, REV. 0}

contaminant. In the 1998 ILAW PA, ${ }^{79}$ Se was seen as the only important radionuclide because of its relatively short half-life and because there was no Hanford Site-specific data indicating that selenium is not mobile. Since then it has been learned that the half-life of ${ }^{79} \mathrm{Se}$ is longer than believed and disposal-site specific information has shown that Se is retarded. However, other elements (iodine and neptunium) which were treated as relatively immobile in the 1998 ILAW PA, are now known through disposal-site specific information to be more mobile. Thus, whereas ${ }^{99}$ TC was $75 \%$ of the drinking water dose in the 1998 ILAW PA, it is only $50 \%$ in this document. Combining the two effects means that the change in mobile inventory cuts the groundwater impacts by about a factor of 2 .

As noted in Section 4.3.4, release from the trench design is about a factor of two less than the corresponding vault design. Although the vault design in this document is somewhat different than that used in the 1998 ILAW PA, the factor of 2 should be approximately correct for the difference for this effect between the 1998 ILAW PA and this document.

In the 1998 ILAW PA, the release from the vaults was assumed to be that given in the request for proposal for treatment services (DOE/RL 1996). In this document, the release from the vault is calculated by calculating the forward rate of release from a BNFL, Inc.-type glass and performing the transport of contaminants through the vault. This results in a slight increase from the 1998 ILAW PA values. It is expected that once the calculations take account of glassin-water saturation effects the calculated values will drop by a factor of ten or more.

As noted in Section 4.4, the disposal site is now realized to be over the old channel of the Columbia River. Thus, the hydraulic conductivity of the unconfined aquifer is higher, resulting in greater dilution, by about a factor of 10 .

Combining these factors (inventory of mobile constituents, disposal facility design, waste form performance, and groundwater dilution), the overall effect is a reduction by about an order of magnitude from the 1998 ILAW PA.

\subsection{Conservatisms and Caveats}

\subsubsection{Overview}

This document is not intended to be a full performance assessment. Many more sensitivity cases will be run for the next version of the ILAW PA which is expected to be issued in 2001. Also, this next PA will have more sophisticated analyses, building on the experience of calculations made for this document. Finally, more data will be collected in the next few years that will improve the quality of future ILAW performance assessments.

\subsubsection{Conservatisms}

The major conservatisms in this analysis revolve around calculational simplifications in the areas of moisture infiltration rates into the facility, the rates at which the waste form releases its constituents, and facility placement for groundwater flow.

The surface barrier and capillary break that are part of facility designed were not modeled in this analysis, resulting in greater moisture fow into the facility. Based on the results contained in the 1998 II.AW PA and because of the relative short life of the surface barrier, the A- 120 
omission of modeling the surface barrier should not significantly affect the results. However, the capillary break is expected to reduce moisture flow into the facility, and based on the 1998 ILAW PA results, a lower rate of waste form dissolution and hence of environmental impacts are expected. The effect of both the surface barrier and the capillary break will be presented in the next version of the ILAW PA.

The calculations of waste form dissolution and contaminant transport in the disposal facility are very complex. This document performed one-dimensional calculations and only used the forward rate of dissolution (which depends on $\mathrm{pH}$ and surface area). Two important effects (treating glass saturation in the pore water and performing two dimensional calculations) are expected to significantly reduce the calculated dissolution rate.

The calculations presented in this white paper only including the forward rate of dissolution. As noted in the section on glass dissolution, as the main components of the glass (especially silica) enter the pore water, the rate of dissolution slows, usually by many orders of magnitude. There is also some evidence, although not yet sufficient to include in long-term analyses, that important contaminants are trapped in secondary glass phases. Thus, these calculations surely overestimate the amount of dissolution that will occur.

Waste form calculations show that the $\mathrm{pH}$ of the pore water and the surface area of the waste form exposed to water greatly affect the rate at which the glass degrades. Onodimensional calculations forces all water to past through the glass and the buffering effect of soil is underpredicted. Twa-dimensional calculations will allow the water to flow around the glass (and stay in the backfill soil), reducing the amount of surface area seen by the water as well as effectively increasing the buffering effect of the soil.

The present disposal site overlies the old channel of the Columbia River. In the present calculations, the disposal facility is placed in the southeast comer of the site. However, because of logistic reasons, the present plans are to place the facility in the northeast comer which is more centered over the old channel. Thus, the effect of the old channel of the Columbia River is underestimated in the calculations reported in this document.

\subsubsection{Caveats}

This effort, as is true for the rest of the ILAW PA effort, is being performed before all decisions concerning ILAW have been made. BNFL, Inc. still must decide on the waste form composition that will be used. Although the BNFL, Inc. flow sheet is becoming finalized, its details still must be transmitted to the ILAW PA activity. Similarly, the detail design for the disposal facility does not yet exist. Finally, although the amount of disposal site-specific information has increased, there is still more data needed.

This analysis is based on a waste form composition in the composition space that BNFL, Inc. has chosen. However, BNFL, Inc. will not select their glass waste form composition for some months. Similarly, the treatment flow sheets used here are those developed by the Hanford Site contractor, rather than BNFL, Inc. BNFt, Inc. will provide to DOE their flow sheets as part of the Phase $1 \mathrm{~b}$ deliverables in April 2000. Nthough the effects of these BNFL, Inc. docisions are expected to be small, the effects must be investigated to determine the size of the change in the environmental impacts. In particular, once the waste form composition is know, significant waste form testing (similarly to that performed for LAWABP1) will be conducted.

$$
\text { A- } 121
$$


The present design for the disposal facility is based on conceptual designs of the existing mixed waste trench at the Hanford Site. As detailed design occurs, it is expected that dimensions will change and materials will be more closely specified. Again, the impacts of these changes are expected to be small.

Finally, more geotechnical data (both from the ILAW disposal site as well as for the Hanford Site as part of the Hanford Site Groundwater / vadose Zone Integration Project) will be obtained. These data will be incorporated to better define conceptual models and the parameters used to implement those models. Based on the 1998 ILAW PA, the effect of the new data will be a better understanding of the flow and transport, but relatively little change in values are expected.

\subsection{Conclusions}

Limited analyses have been conducted based on new data and programmatic changes that have occurred since the ILAW PA was issued (Mann 1998a). New site specific data have been collected, the estimate for the IIAW inventory has been revised, waste form data have been collected for relevant glass formulations, and the groundwater model for the Hanford Site local to the ILAW disposal site have been improved. Programmatic changes include the selection of a waste form composition and fabrication process provided by BNFL, Inc. and the selection of a new remote handled trench concept for the ILAW disposal facility.

The results from these analyses have shown that the peak release rate $(7 \mathrm{ppm} / \mathrm{y})$ from the RH trench facility at 10,000 years is approximately $60 \%$ greater than the release rate (4.4 ppm/y) used in the last ILAW performance assessment. Also, the groundwater flow beneath the current ILAW disposal site is higher than estimated in the last performance assessment. These estimates have lead to estimated impacts that are a factor of approximately 24 or more below the performance objectives for the groundwater related scenarios. The results for the inadvertent intruder are comparable to the results provided in the last performance assessment.

Finally, selected sensitivity calculations were performed for key assumptions associated with inventory, facility design, and waste form performance. The estimated impact for the continuous exposure scenario is closest to the performance objectives in this analysis update. This estimated impact is based on four packages having average inventories of the IIAW radionuclides. These estimated impacts can be mitigated through operational controls based on projected container inventories. Such operational controls will be better defined as the project matures. The results from these analyses togeher with the results from the last ILAW PA (Mann 1998a) provide reasonable assurance that the current disposal system will adequately protect the public and the environment. 


\subsection{REFERENCES}

10 CFR 61, "Licensing Requirements for Land Disposal of Radioactive Waste," Nuclear Regulatory Commission, Code of Federal Regulations, as amended.

40 CFR 61H, Subpart H, "National Emission Standards for Emissions of Radionuclides Other than Radon from Department of Energy Facilities," Code of Federal Regulations, Volume 40, Part 61, Subpart H, Section 92, U.S. Environmental Protection Agency, Washington, D.C., December 15, 1989.

40 CFR 61Q, Subpart Q "National Emission Standards for Radon Emissions from Department of Energy Facilities, " Code of Federal Regulations, Volume 40, Part 61, Subpart Q, Section 192, U.S. Environmental Protection Agency, Washington, D.C.,

40 CFR 141, "National Primary Drinking Water Regulations, "Code of Federal Regulations, Volume 40, Part 141, Sections 15 and 16, U.S. Environmental Protection Agency, Washington, D.C., December 24, 1975.

40 CFR 268, "Land disposal restrictions" (40 CFR 268), Code of Federal Regulations, Volume 40, Parts 268, U.S. Environmental Protection Agency, May 19, 1980 and as amended.

Bacon 2000, D.H. Bacon, M.D. White, and B.P. McGrail, Subsurface Transport Over Reactive Multiphases (STORM): A General, Coupled Nonisothermal Multiphase Flow, Reactive Transport, and Porous Medium Alteration Simulator, Version2., User's Guide, PNNL13108, Pacific Northwest National Laboratory, Febriary 2000.

BNFL 1998, Waste Products and Secondary Waste Plan, Tank Waste Remediation System Privatization Project, BNFL-5193-01, Revision 0, British Nuclear Fuels, Limited, Incorporated, Richland, Washington, January 1998.

BNFL, 1999, TWRS-P Project Dangerous Waste Permit Application, BNFL-5193-RCRA-01, Rev. OA

Brodzinski 1998; R.L. Brodzinski, e-mail to F.M. Mann, October 19, 1998.

Cloke 1997, P.L. Cloke, D.M. Jolley, and D.H. Lester, Waste Package Development Design Analysis, BBA000000-01717-0200-0050 Rev. 00, CRWMS/M\&O, Las Vegas, Nevada, 1997.

Cole 1997, Cole, C. R., S. K. Wurstner, M. P. Bergeron, M. D. Williams, P. D. Thorne Threedimensional Analysis of Future Groundwater Flow Conditions and Cortaminant Plume Transport in the Hanford Site Unconfihed Aquifer System: FY 1997 Status Report. PNNL-11801, Pacific Northwest Laboratory, Richland, Washington, December 1997.

DOE 1988, Radioactive Waste Management, DOE Order 5820.2A, U.S. Department of Energy, Washington D.C., September 26; 1988. 
DOE 1993, "Radiation Protection of the Public and the Environment", DOE Order 5400.5, U.S. Department of Energy, Washington, D.C., January 7, 1993.

DOE 1994, Remedial Investigation and Feasibility Study Report for the Environmental Restoration Disposal Facility. DOE/RL-93-99, Rev. 1, U.S. Department of Energy, Richland, Washington, 1994.

DOE 1997a, Record of Decision for the Tank Waste Remediation System, Hanford Site, Richland, Washington, Federal Register, Volume 62, page 8693, February 26, 1997.

DOE 1997b, Final Waste Management Progranmatic Environmental Impact Statement For Managing Treatment, Storage, and Disposal of Radioactive and Hazardous Waste, DOE/EIS-0200-, U.S. Department of Energy, Washington, D.C., May 1997.

[Note that this EIS does not separate the Hanford tank waste into low- and high-level components.]

DOE 1999a, "Radioactive Waste Management", DOE 0 435.1, U.S. Department of Energy, Washington, D.C., July 9, 1999.

DOE 1999b, Mamual for DOE O 435.I", DOE M 435.1, U.S. Department of Energy, Washington, D.C., July 9, 1999.

1. Performance assessment requirements are presented in Chapter IV (Low-Level Waste), section P (disposal).

DOE 1999c, Final Hanford Comprehensive Land-Use Plan Environmental Impact Statement, DOE/EIS-0222-F, U.S. Department of Energy, Richland, Washington, September 1999. The Record of Decision was published in the Federal Register on November 12, 1999 (Vol. 64, pages 61615-61625).

DOE 1999d, Conditional Acceptance of the Immobilized Low-Activity Tank Waste Disposal Facility Performance Assessment and the Hanford Site 200 Plateau Composite Analysis, Memorandum from James J. Fiore and Mark W. Frei to Richard French and Keith A. Klein, U.S. Department of Energy, Washington, D.C., October 20, 1999.

DOE/BNFL 1998, TWRS Privatization Contract No. DE-AC06-96RL13308, Contract with British Nuclear Fuels, Ltd., U.S. Department of Energy, Richland Operations Office, September 1998, Richland, Washington.

- Modification 12 (January 24, 2000) - see web reference http://www.hanford.gov/doe/contracts/de-ac06-96r113308/index.html

DOE/RL 1991, Hanford Site Risk Assessment Methodology, DOE/RL-91-45, Revision 3, U.S. Department of Energy, Richland, Washington, 1991.

DOE/RI 1996a, Request for Proposals (RFP) No. DE-RP06-96RL13308, letter from J.D. Wagoner to Prospective Offerors, Department of Energy, Richland, Washington, February 20, 1996. 
DOE/RL 1997, Screening Assessment and Requinements for a Comprehensive Assessment: Columbia River Comprehensive Impact Assessment, DOE/RL-96-16, Revision 0, U.S. Department of Energy, Richland, Washington, 1997.

DOE/RL 1999, 200-BP-1Prototype Barrier Treatability Test Report, DOE/RL-99-11, Revision O, U.S. Department of Energy, Richland, Washington, 1997.

Ecology 1998, Washington State Department of Ecology, United States Environmental Protection Agency, United States Department of Energy, Hanford Facility Agreement and Consent Order, as amended through December 31, 1998, 89-10, Rev. 6. This document is available from any of the parties.

[1. Appendix D lists the activities and associated milestones. Activities 45 (closure of single-shell tanks), 50 (pretreatment processing), 60 (vitrification of Hanford low-level waste), and 90 (disposal of the immobilized low-activity waste) cover areas of concern for this performance assessment.]

Fayer and Walters 1995, M. J. Fayer and T. B. Walters, Estimated Recharge Rates at the Hanford Site. PNL-10285, Pacific Northwest Laboratory, Richland, Washington, 1995.

Fayer 1999, M.J. Fayer; Recharge Data Package for the Immobilized Low-Activity Waste 2001 Performance Assessment, PNNL-13033, , Pacific Northwest National Laboratory, Richland, Washington, December 1999. Also Appendix J of Mann/Puigh 2000.

French 1999, RT. French, "Disposal Authorization for the Hanford Site Low-Level Waste Disposal Facilities," memorandum to M.W. Frei (Deputy Assistant Secretary, Office of Project Completion), Office of River Protection, U.S. Department of Energy, December 29, 1999.

Gupta 1987, Gupta, S. K., C. R Cole, C. T. Kincaid, and A. M. Monti, Coupled Fluid, Energy, and Solute Transport (CFEST) Model: Formulation and User's Mamual. BMI/ONWI660, Battelle Memorial Institute, Columbus, Ohio, October 1987.

Harris 1992, A. W. Harris, A. Atkinson, and P. A. Claisse, "Transport of Gases in Concrete Barriers," Waste Management, 12:155-178, 1992.

Hendrickson 1999, D. W. Hendrickson, D. E. Place, G. T. MacLean, S. L. Lambert, Best-Basis Wash and Leach Factor Analysis, HNF-3157, Rev. OA, COGEMA Engineering, Richland, Washington, January 1999.

HFSUWG 1992, The Future for Hanford: Uses and Cleamp, Summary of the Final Report of the Hanford Future Site Uses Working Group, Document number 0026618, December 1992. This report is available through the Environmental Data Management Center, Lockheed Martin Services, Incorporated, Richland, Washington.

[1. Page 9 discusses use the central plateau wisely for waste management.]

Huyakon and Panday 1999, P.S. Huyakon and S Panday, VAM3DF - Variably Saturated Analysis Model in Three Dimensions for the Data Fussion System: Documentation and User's Guide, Version 2.0, HydroGoologic, Inc., Herndon, Virginie, 1999. 
Kaplan 1999, D.L. Kaplan And R.J. Serne, Geochemical Data Package For The Immobilized Low-Activity Waste Performance Assessment, PNNL - 13037, Pacific Northwest National Laboratory, Richland, Washington, December 1999. Also Appendix N of Mann/Puigh 2000.

Khaleel 1999, R. Khaleel, , Far-Field Hydrology Data Package For The Immobilized LowActivity Waste Performance Assessment, HNF-4769, Rev. 2, Fluor Federal Services, Richland, Washington, December 1999. Also Appendix M of Mann/Puigh 2000.

Kincaid 1995, C.T. Kincaid, J.W. Shade, G.A. Whyatt, M.G. Piepho, K. Rhoads, J.A. Voogd, J.H. Westsik, Jr., K.A. Blanchard, and B.G. Lauzon, Pefformance Assessment of Grouted Double-Shell Tank Waste Disposal at Hanford, WHC-SD-WM-EE-004, Revision 1, Westinghouse Hanford Company, Richland, Washington, May 1995.

[1. Section 3.3.6.6 on page 3.62 describes the effective diffusion constant for the vadose zone.]

Kincaid 1998, C. T. Kincaid,., M. P. Bergeron, C. R. Cole, M. D. Freshley, N. L. Hassig, V. G. Johnson, D. I. Kaplan, R. J. Serne, G. P. Streile, D. L. Strenge, P. D. Thorne, L. W. Vail, G. A. Whyatt, S. K. Wurstner, Compasite Analysis for Low-Level Waste Dispasal in the 200-Area Plateau of the Hanford Site. PNNL-11800, Pacific Northwest National Laboratory, Richland, Washington, March 1998.

Kirkbride 1999, R. A. Kirkbridge, Tank Waste Remediation System Operational Uttlization Plan, HNF-SD-WM-SP-012, Rev. 1, Volume I and II, Numatec Hanford Company, Richland, Washington, May 1999.

Kupfer 1999, M. J. Kupfer., AL. Boldt, B.A. Higley, K.M. Hodgson, L.W. Shelton, B.C. Simpson, R.A. Watrous, M.D. LeClair G.L. Borsheim, R.T. Winward, R.M. Orme, N.G. Colton, S.L. Lambert, D.E. Place, and W.W. Schuln, 1999, Standard Inventories of Chemicals and Radionuclides in Hanford Site Tank Wastes, HNF-SD-WM-TI-740, Rev. OC, Lockheed Martin Hanford Corporation, Richland, Washington, February 1999.

Law 1996, A. Law, S. Panday, C. Denslow, K. Fetch, A. Knepp, Hanford Sitewide Groundwater Flow and Transport Model Calibration Report, BHI-00608, Rev. 0, Bechtel Hanford Inc., Richland, Washington, April 19\%. Further work on calibration has been done and has been documented as Rev. 1, issued in September 1997.

Lindsey 1995, K. A. Lindsey, Miocene-to Pllocene-Aged Suprabasalt Sediments of the Hanford Site, South-Central Washington. BHI-00184, Rev. 0, Bechtel Hanford, Inc., Richland, Washington, 1995.

Lu 1996, A H. Lu, Contaminant Transport in the Unconfined Aquifer, Input to the Low Level Tank Waste Interim PA, WHC-SD-WM-RPT-241, Westinghouse Hanford Company, Richland, Washington, June 1996.

Mann 1995, F. M. Mann, Data Packages for the Hanford Low-Level Tank Waste Interim Performance Assessment, WHC-SD-WM-RPT-166, Revision 0, Westinghouse Hanford Company, Richland, Washington, July 1995. 
Mann 1996a, F. M. Mann, C. R. Eiholzer, A. H. Lu, P. D. Rittmann, N. W. Kline, Y. Chen, B. P. MoGrail, Performance Assessment, WHC-EP-0884, Rev. 0, Westinghouse Hanford Company, Richland G.F. Williamson, and N. R. Brown, Hanford Low-Level Tank Waste Interim, Washington, September 1996.

Mann 1996b, F. M. Mann, INTEG: A Program to Calculate Groundwater Contamination and Human Doses, WHC-SD-WM-RPT-219, Westinghouse Hanford Company, Richland, Washington, June 1996.

Mann 1998a, F. M. Mann, R. J. Puigh II, P. D. Rittmann, N. W. Kline, J. A. Voogd, Y. Chen, C. R. Eiholzer, C. T. Kincaid, B. P. McGrail, A.H. Lu, G.F. Williamson, N. R. Brown, and P. E. LaMont, Hanford Immobilized Low-Acttvity Tank Waste Performance Assessment, DOE/RL-97-69, Rev. 0, U.S. Department of Energy, Richland, Washington, March 1998.

Mann 1998b, F. M. Mann, and D. A. Myers, Computer Code Selection Criteria for Flow and Transport Code(s) To be Used in Undisturbed Vadose Zone Calculations for TWRS Environmental Analyses, HNF-1839, Lockheed Martin Hanford Corporation, Richland, Washington, January 1998.

Mann 1999a, F. M. Mann, Performance Objectives for the Hanford Immobilized Low-Activity Waste (ILAW) Performance Assessment, HNF-EP-0826, Revision 3, Fluor Daniel Northwest, Inc. , Richland, Washington August 1999. Also Appendix A of Mann/Puigh 2000.

Mann 1999b, Scenarios for the Hanford Immobilized Low-Activity Waste (ILAW) Performance Assessment, HNF-EP-0828, Rev. 3, Lodkheed Martin Hanford Company, Richland, Washington, August 1999. Also Appendix B of Mann/Puigh 2000.

'Mann/Puigh 2000, F. M. Mann and R. J. Puigh II, Data Packages for the Hanford Immobilized Low-Activity Tank Waste Performance Assessment: 2001 Version, HNF-5636, Fluor Federal Services, Richland, Washingtos, February 2000.

McGrail, 1997, B. P. McGrail, P. F. Martin, and C. W. Lindenmeier. "Accelerated Testing of Waste Forms Using a Novel Pressurized Unsaturated Flow (PUF) Method." Mat. Res. Soc. Symp. Proc. 465:253-260.

McGrail 1998a, B. P. McGrail and D. H. Bacom, Selection Of A Computer Code For Hanford Low-Level Waste Engineered-System Performance Assessment, PNNL-10830 Rev. 1, Pacific Northwest National Laboratory, Richland, Washington, March 1998.

MoGrail, 1998b, B. P. MoGrail, W. L. Ebert, D. H. Bacon, and D. M. Strachan. A Strategy to Conchuct an Analysils of the Long-Term Performance of Low-Activity Waste Glass in a Shallow Subsurface Disposal System a Hanford, PNNL-11834, Pacific Northwest National Laboratory, Richland, Washington. 
McGrail 1999, B. P. McGrail, D. H. Bacon, J. P. Icenhower, W. L. Ebert, P. F. Martin, H. T.

Schaef, and E. A. Rodriguez, Waste Form Release Data Package for the 2001

Immobilized Low-Activity Waste Performance Assessment, PNNL-13043, Pacific

Northwest National Laboratory, Richland, Washington, December 1999. Also Appendix

K of Mann/Puigh 2000.

McGrail, 2000, B. P. McGrail, J. P. Icenhower, D. K. Shuh, J. G. Darab, D. R. Baer, S.

Thevuthasen, V. Shutthanandan, and M. H. Englehard. 2000. "The Structure of $\mathrm{Na}_{2} \mathrm{O}$ $\mathrm{Al}_{2} \mathrm{O}_{3}-\mathrm{SiO}_{2}$ Glasses and Its Impact on Sodium Ion Exchange in $\mathrm{H}_{2} \mathrm{O}, \mathrm{D}_{2} \mathrm{O}$, and $\mathrm{D}_{2}{ }^{18} \mathrm{O}$. Submitted to J. Non-Cryst. Solids.

Meyer 1999, P. D. Meyer and R. J. Serne, Near Field Hydrology Data Package for the Immobilized Low-Activity Waste 2001 Performance Assessment, PNNL-13035, Revision 1, Pacific Northwest National Laboratory, Richland, Washington, December 1999. Also Appendix L of Mann/Puigh 2000.

Millington-Quirk 1961, R. J. Millington and J. P. Quirk, "Permeability of Porous Solids," Trans Faraday Soc., 57:1200-1207, 1961.

Napier 1984, B. A. Napier, R. A. Peloquin, W. E. Kennedy Jr., and S. M. Neuder, Intruder Dose Pathway Analysis for the Onsite Disposal of Radioactive Waste: The ONSITEMAXII Computer Program, NUREG/CR-3620, U.S. Nuclear Regulatory Commission, Washington, D.C., 1984.

Nozaki 2000, A. Nozaki, B. P. McGrail, M. J. Fayer, and K. P. Saripalli. 1999. “A Coupled Mechanical-Chemical Stability Analysis for a Low Activity Waste Disposal Facility at the Hanford Site." Computers \& Structures (submitted).

NRC 1988, Standard Review Plan For The Review Of A License Application For A Low-Level Radioactive Waste Disposal Facility, NUREG-1200, Rev. 1, U.S. Nuclear Regulatory Commission, Washington, D.C. January 1988.

NRC 1997, Branch Technical Position on a Penformance Assessment Methodology for LowLevel Radioactive Waste Disposal Facilities (draft for public comment). NUREG-1573. Low-Level Waste Management Branch, U.S. Nuclear Regulatory Commission, Washington, D.C., May 1997.

Paperiello 1997, C. J. Paperiello (Director of Office of Nuclear Material Safety and Safeguards), letter dated June 1997 to Jackson Kinzer (assistant Manager, Office of Tank Waste Remediation Systems), "Classification of Hanford Low-Activity Tank Waste Fraction," U.S. Nuclear Regulatory Commission, Washington, D.C. \{ see Mann 1998b - Appendix F.2.3\}.

Patello 1999, G. K. Patello, M. J. Truex, and K. D. Wiemers, Low-Activity Waste and High-Level Waste Feed Processing Data Quality Objecttves, PNNL-121163, Rev. 0, Pacific Northwest National Laboratory, Richland, Washington, April 1999. 
Pickett 1998, W. W. Pickett, Immobilized Low-Activity Waste Interim Storage Facility, Project W-520 Conceptual Design Report [DRAFT], HNF-3013, Rev. B, Fluor Daniel Northwest Company, Richland, Washington, September 1998.

Puigh 1999, R. J. Puigh II, Disposal Facility Data for the Hanford Immobilized Low-Activity Tank Waste, HNF-4950, Rev. 1, Fluor Federal Services, Richland, Washington, December 1999. Also Appendix I of Mann/Puigh 2000.

Rawlins 1994, J. A. Rawlins, R. A Karnesky, R. Khaleel, A. H. Lu, F. M. Mann, B. P. McGrail, W. J. McMahon, M. G. Piepho, P. D. Rittmann, and F. A. Schmittroth, Impacts of Disposal System Design Options on Low-Level Glass Waste Disposal System Performance, WHC-EP-0810, Revision 0, Richland, Washington, September 1994.

Reidel 1997, S. P. Reidel, Characterization Plan for the Immobilized Low-Activity Borehole, PNNL-1 1800, Pacific Northwest National Laboratory, Richland, Washington, December 1997.

Reidel 1999, S. P. Reidel and D. G. Horton, Geologic Data Packages for $200 \mathrm{I}$ Immobilized Low-Activity Waste Performance Assesiment, PNNL-12257, Rev. 2, Pacific Northwest National Laboratory, Richland, Washington, December 1999. Also Appendix G of Mann/Puigh 2000.

Rittmann 1993, P. D. Rittmann, GRTPA - A Program to Calculate Human Dase from PORFLOW Output, WHC-SD-WM-UM-018, Westinghouse Hanford Company, Richland, Washington, November 1993.

Rittmann 1999, P. D. Rittmann, Expasure Scenarios And Unit Dase Factors For The Hanford Immobilized Low-Activity Tank Waste Performance Assessment, HNF-SD-WM-TI-707, Rev. 1, Fluor Federal Services, Richland, Washington, December 1999. Also Appendix O of Mann/Puigh 2000.

Rutherford 1997, W. A. Rutherford (Director, Site Infrastructure Division), letter 97-SID-285 to H.J. Hatch (President of Fluor Daniel Hanford, Inc.), "Contract DE-AC06-96RL113200 Approval of Tank Waste Remediation System Complex Site Evaluation Report", dated July 10, 1997, Department of Energy, Richland, Washington.

Schmittroth 1995, F. A. Schmittroth and T. H. DeLorenzo, Consequence Raniting of Radionuclides in Hanford Tanks Waste, WHC-SD-WM-RPT-163, Revision 0, Westinghouse Hanford Company, Richland, Washington, September 1995.

Taylor 1999a, W. J. Taylor, Contract No. DE-AC06-99RL14047 - Decision to Change the Immobilized Low-Activity Waste (ILAW) Disposal Baseline to Proceed with the RemoteHandled Trench Alternative, letter 99-DPD-066 (correspondence control number 9958849), Department of Energy, Richland, Washingtom, December 1, 1999. 
Taylor 1999b, W. J. Taylor, Contract N0. DE-AC06-96RL13200 Planning Guidance revisions for Development of Contract Deliverable Required by Performance Agreement TWR1.3.5, letter 99-AMPD-006 (correspondence control no. 9952261A), Department of Energy, Richland, Washington.

Thome 1992, P. D. Thome, P. D., and M. A. Chamness, Status Report on the Development of a Three-Dimensional Conceptual Model for the Hanford Site Unconfined Aquifer System. PNL_8332, Pacific Northwest Laboratory, Richland, Washington, 1992.

Thome 1993, P. D. Thorne, M. A. Chamness, F. A. Spane Jr., V. R. Vermeul, and W. D. Webber, Three-Dimensional Conceptual Model for the Hanford Site Unconfined Aquifer System, FY 93 Status Report. PNL-8971, Pacific Northwest Laboratory, Richland, Washington, 1993.

Thome 1994, P. D. Thome, M. A. Chamness, V. R. Vermeul, Q. C. MacDonald, and S. E. Schubert, Three-Dimensional Conceptual Model for the Hanford Site Unconfined Aquifer System, FY 1994 Status Report. PNL-10195, Pacific Northwest Laboratory, Richland, Washington, 1994.

Vienna 2000, J. D. Vienna, A. Jiricka, B. P. McGrail, B. M. Jorgensen, D. E. Smith, B. R. Allen, J. C. Marra, D. K. Peeler, K. G. Brown, I. A. Reamer, and W. L. Ebert. 2000. Hanford Immobilized LAW Product Acceptance Testing: Initial Data Package. PNNL-13101, Pacific Northwest National Laboratory, Richland, Washington.

Voogd 1999, J. A. Voogd, F. M. Mann, and A. J. Knepp, Recommendations for Computer Code Selection of a Flow and Transport Code to be Used in Undisturbed Vadase Zone Calculations for TWRS Immobilized Wastes, HNF-4356, Lockheed Martin Hanford Corporation, Inc., April 1999.

WAC 173-201A, "Water Quality Standards for Surface Waters of the State of Washington," Washington State Administrative Code 173-201A, Washington State Department of Ecology, Olympia, Washington, December 22, 1992.

WAC 173-303-140, "Washington State Dangenous Waste Regulations," Washington State Administrative Code 173-303, Washington State Department of Ecology, Olympia, Washington, December 1992.

Wagoner 1996, J. D. Wagoner (Manager, Richland Operations), letter to contractors, Richland, Washington, re: “Single 'Groundwater Project' for the Hanford Site', Department of Energy, Richland, Washington, September 5, 1996.

Walters 1994, W. H. Walters, M. C. Richmond, and B. G. Gilmore, Reconstruction of Radiomuclide Concentrations in the Columbia Rtuer from Hanford, Washington to Portland, Oregon, Jamuany 1950 - Janyary 1971. BNWD-2225 HEDR, Pacific Northwest Laboratory, Richland, Washington, 1994.

Wiemers 1998, K. D. Wiemers, M. E. Lerchen, M. Miller, K. Meier, Regulatory Data Quality Objectives Supporting Tank Waste Reriediation System Privatization Project, PNNL 12040, Rev. 0., Pacific Northwest National Laboratory, Richland, Washington.

$$
A-130
$$


Wood 1994, M. I. Wood, R. Khaleel, P. D. Rittmann, A. H. Lu, S. H. Finfrock, R. J. Serne, and K. J. Cantrell, Performance Assessment for the Disposal of Low-Level Waste in the 200 West Area Burial Grounds, WHC-EP-0645, Westinghouse Hanford Company, Richland, Washington, November 1994.

[1. Section 4.3.1 provides the calculation of the release of contaminants to air]

Wood 1996, M. I. Wood, Performance Assessment for the Disposal of Low-Level Waste in the 200 East Area Burial Grounds, WHC-EP-0875, Westinghouse Hanford Company, Richland, Washington, September 1996.

Wootan 1999, D. W. Wootan, Immobilized Low Activity Tank Waste Imventory Data Package, HNF-4921, Rev. 0, Fluor Daniel Northwest, Inc., September 1999. Also appendix H of Mann/Puigh 2000.

Wurstner 1995, S. K. Wurstner, P. D. Thorne, M. A. Chamnes, M. D. Freshley, and M. D. Williams, Development of a Three-Dimensional Ground-Water Model of the Hanford Site Unconfined Aquifer System: FY 1995 Status Report, PNL-10886, Pacific Northwest National Laboratory, Richland, Washington, December 1995.

Wurstner 1997, Wurstner, S. K., P. D. Thorne, M. A. Chamness, M. D. Freshley, and M. D. Williams. Development of a Three-dimensional Groundwater Model of the Hanford Site Unconfined Aquifer System: FY 1995 Status Report. PNL-10886, Pacific Northwest Laboratory, Richland; Washington, December 1997. 


\subsection{PEER REVIEW}

Each of the individual data packages on which this assessment is based was reviewed by Hanford Site technical staff, Department of Energy personnel, and outside technical peer reviewers.

This document was reviewed by the Immobilized Low-Activity Waste performance assessment team, as well as by program management of the Immobilized Waste Storage and Disposal Program (R.W. Root) and of the Department of Energy's Office of River Protection (N.R. Brown, P.E. LaMont, and others). In addition, the lead authors of other Hanford Site performance assessments (C.T. Kincaid [Grout Performance Assessment and Hanford Site Composite Analysis] and M.I. Wood [200 East Area Solid Waste Performance Assessment and 200 West Area Solid Waste Performance Assessment]) performed an overall technical review of this report. 


\subsection{PREPARERS AND MAJOR REVIEWERS}

DIANA H, BACON, Senior Research Scientist, Hydrology Group, Pacific Northwest National Laboratory

B.S. Geology, George Mason University

M.S. Hydrology, New Mexico Institute of Mining \& Technology 1986

Ph.D. Geology, Washington State University

Dr. Bacon has over 15 years of experience in vadose zone hydrology and geochemistry and numerical simulations of subsurface flow and transport. As a part of her doctoral studies, Dr. Bacon developed an inverse multiphase reactive transport code to simulate the effect of heterogeneous soil properties and transient changes in transport parameters on fractionation between $\mathrm{CO}_{2}$ and the source of $\mathrm{CO}_{2}$ in the vadose zone. In support of the Hanford Tank Lowactivity Waste Glass Performance Assessment Project and the Yucca Mountain Project, Dr. Bacon is currently developing the coupled nonisothermal, multiphase flow and transport code, STORM. She performed the waste form release calculations.

MARCEL P. BERGERON, Program Manager, Hydrology Group, Pacific Northwest National Laboratory

B.A. Geology, University of Vermont

Mr. Bergeron joined Battelle, Pacific Northwest Laboratories in May 1985 as a Research Hydrogeologist and has 21 years experience in a wide variety of ground-water investigations and studies at hazardous waste and contaminated ground-water sites. Since joining Battelle, Mr. Bergeron has devoted his attention to a variety of roles in hydrologic studies and investigations including technical contributions, project and task management, and line management roles. Technically, he has specialped in the area of hydrogeologic inveatigations with specific emphasis on the application of ground-water flow and transport modeling. He performed the regional and local-scale groundwater flow and transport modeling used to support this assessment.He lead and oversaw the groundwater calculations.

NEIL R. BROWN, Project Manager, U.S. Department of Energy, Office of River Protection

B.S. Material Science and Engineering, Rice University

$\mathrm{Ph} . \mathrm{D}$. Material Science and Engineering, Notthwestern University

Before joining DOE, Dr. Brown was a post doctoral fellow at the Argonne National Laboratory where he studied corrosion characteristics of waste glass and soil remediation. At DOE, he has overseen technology development for the Low-Level Waste Program as well as the development of TWRS privatization specifications. Currently Dr. Brown is the DOE Contract Officer for British Nuclear Fuels, Limited's effort as part of TWRS privatization. He reviewed this document. 
SCOTT H, FINFROCK, Nuclear Engineer, Nuclear and Environmental Initiatives, Flour Federal Services

B.S. Engineering, University of Washington

M.S. Nuclear Engineering, University of Washington

M.S. Computer Science, Washington State University

Scott Finfrock has over 15 years of experience in numerical simulations of transport of radiation and radioactive materials. He was a key contributor to the Hanford Site solid waste performance assessments, particularly in the area of modeling transport through the vadose zone and groundwater. For this PA he he was primarily responsible for integrating the results of the various calculations to determine the total impact from the disposal system. He merged the results of the various calculations to determine the total impact from the disposal system.

EUGENE J. FREEMAN, Hydrogeologist, Nuclear and Environmental Initiatives, Flour Federal Services

B.S. Geology, Montana State University

M.S. Hydrology, University of Idaho

Mr. Freeman has ten years of experience in the field of hydrogeology. He has experience as a field hydrogeologist and numerical modeler. Mr. Freeman has performed work for both saturated and unsaturated systems and has spent the past eight years analyzing and modeling moisture and contaminant distribution within the unsaturated sediments beneath Hanford. He performed the vadose zone modeling outside of the waste package area.

RAZIUDDIN KHALEEL, Consulting Engineer, Nuclear and Environmental Initiatives, Flour Federal Services

B.S. Civil Engineering, Bangladesh Univertity of Engineering and Technology

M.S. Water Science and Engineering, Asian University of Technology

Ph.D. Soil and Water Engineering, Texas A\&M University

Dr. Khaleel has over 25 years of experience in groundwater hydrology and numerical simulations of subsurface flow and transport. He was a key contributor to the Hanford Site solid waste performance assessments and immobilized low-activity waste performance assessment, particularly in the area of conceptual model development, direction of modeling, and in writing the document. For this document, he reviewed the approach, models, and results. 
CHARLES T. KINCAID, Staff Scientist, Hydrology Group, Pacific Northwest National Laboratory

B.S. Civil Engineering, Humboldt State College 1970

Ph.D. Engineering (Hydraulics), Utah State University

Dr. Kincaid was the technical manager and key contributor to the Performance Assessment of the Grouted Double-Shell Tank Waste Disposal at Hanford and to the Composite Analysis for the Low-Level Waste Disposal in the 200 Area Platean of the Hanford Site. He has been the Technical Group Leader of the Soil Physics Group and of the Subsurface Transport Group. He was a key contributor in the development of contaminant transport codes and has contributed to various performance assessments. Dr. Kincaid reviewed this document.

PHILIPE. LaMONT, General Engineer, U.S. Department of Energy Office of River Protection

B.S. Chemical Engineering, Washington State University 1965

M.S. Chemical Engineering, University of Idaho

Mr. LaMont is a project director in the Hanford Site Tank Waste Remediation System Office. He has more than 20 years of experience in nuclear waste management. Mr. LaMont reviewed this document as part of his responsibility for managing projects for storage and disposal of the immobilized waste products from the planned treatment of Hanford Site tank waste.

EREDERICK M.MANN, Consulting Scientist, Nuclear and Environmental Initiatives, Flour Federal Services

B.S. Physics, Stanford University

Ph.D. Physics, Califormia Institute of Technology

Dr. Mann is the team leader for the Tank Waste Performance Assessment Activity, which is charged with preparing this white paper. He pras the main author of the Hanford Immobolized Low-Activity Tank Waste Performance Assessitent. He has worked for over 20 years in the field of nuclear data and the application of that data to large energy facilities. He has advised the U.S. Department of Energy and the International Atomic Energy Agency. He is one of the main authors of this document.

B. PETER MCGRAI, Staff Scientist V, Applied Geology and Geochemistry Department, Environmental Technology Division, Pacific Northwest National Laboratory

B.S. Nuclear Engineering, University of Missouri

Ph.D. Environmental Engineering, Columbie Southern University (Magna Cum Laude) 1996

Dr. McGrail has been a staff member at PNNL for over 17 years and is the principal investigator and manager of a diverse range of projects including the DOE's Fissile Materials Disposition Program, Yucca Mountain Project, Hanford Low-Activity Tank Waste Disposal Project, a basic

$$
\text { A-135 }
$$


science (EMSP) project exploring ion-exchange processes in glasses, and a laboratory directed R\&D program exploring carbon sequestration processes in deep geologic formations. He is internationally known for his research on performance assessment of waste disposal systems, coupled diffusion-advection-reaction transport modeling, and corrosion of silicate glasses, with one patent and over 150 publications and presentations on these topics. He has performed hundreds of experiments to evaluate the dissolution kinetics of waste forms and other geologic materials using batch and flow-through techniques, and has invented test equipment for conducting these measurements that operates under both water-saturated and unsaturated conditions. He recently completed development of an inverse reactive transport simulator (INVERTS), which is being used to model elution profiles of solutes and colloids from unsaturated flow experiments, including equilibrium and nonlinear kinetic adsorption processes. He also manages PNNL's new X-ray Microtomography Laboratory and has been exploring application of high-resolution $x$-ray microtomography to develop a better understanding of multiphase flow and mass transport processes in porous media. Dr. McGrail directed the collection and analysis of the laboratory data used in the waste form release calculations discussed in this document.

RAYMOND J. PUIGH II Manager, Nuclear and Environmental Initiatives, Fluor Federal Services

B.S. Physics, Louisiana State University

Dr. Puigh has over 20 years of experience in nuclear fields ranging from nuclear data and testing to the impact of nuclear radiation on material pyoperties. Relevant performance assessment experience includes metallurgy, tank waste inventory support, safety assessment support for selected tank farm operation projects, and management of environmental modeling staff responsible for the Hanford Solid Waste and IIAW performance assessments. He is one of the main authors of this document.

\section{RALPH W. (BILL) ROOT,}

\section{B.S. Chemical Engineering, Oregon State University \\ M.S. Chemical Engineering, University of Arizona}

Mr. Root has more than twenty-five years experience in developing and completing engineering/construction projects for nuclear and coal-fired plants, environmental remediation projects, and waste treatment projects. Relevapt performance assessment experience includes project management for Retrieval, Infrastructure, and Immobilized Waste projects for the Tank Waste Remediation System. Mr. Root was also responsible for the technical development of a $\$ 100$ million analytic and treatment technology deployment facility for mixed and hazardous waste. At Battelle Memorial Institute he was yesponsible for the development of new environmental technology applications. As part of his responsibilities as the manager of the Immobilized Waste Storage and Disposal Program, he reviewed this document. 
MARCUS I. WOOD, .Principal Scientist, Waste Management, Fluor Hanford, Inc.

B.S. Geology, University of North Carolina

Dr. Wood is currently responsible for the development of the PA analyses for the disposal of solid low-level waste at the Hanford Site. He is the coordinating author of this document and has been largely responsible for the integration and the interpretation of the analytical results in this document. He has coordinated similar analyses for the Environmental Restoration Disposal Facility (ERDF), which is planned for disposing of wastes generated in the remediation of Hanford CERCLA sites and the 200 West Area low-level burial grounds. In the past, he has directed numerous projects to quantify the geochemical properties of radionuclides in the Hanford geohydrologic environment. He was also responsible for developing a multifunctional waste package backfill material for isolating spent fuel and high-level waste. He reviewed this document.

SIGNE K. WURSINER, Senior Research Scientist, Hydrology Group, Pacific Northwest National Laboratory

B.S. Geology, Indiana University

M.S. Geology, Indiana University

Ms. Wurstner joined Battelle as a full-time scientist October 1989. Her primary interests include numerical modeling of groundwater flow and transport processes and geographic information systems (GIS). Ms. Wurstner has been primarily involved in modeling groundwater flow and contaminant transport at the Hanford Site in both two and three dimensions, and was a major contributor to the development of an interface between the CFEST groundwater modeling software library and the commercial GIS package, ARC/INFO. She assisted in the regional and local-scale groundwater flow and transport modeling used to support this assessment. 


\section{DISTRIBUTION SHEET}

To

DISTRIBUTION

Project Title $M$ Work Order

Annual Summary of ILAW Performance Assessment

\section{Name}

U.S. Department of Energy, ORP

ORP Correspondence Control

C. A. Babel (20)15

P. E. LaMont

U.S. Department of Energy, RL

R. D. Hildebrand

CH2M HILL Hanford Group, Inc.

D. A. Burbank, Jr.

K. C. Burgard

A. J. Knepp

R. W. Root

J. A. Voodg

Fluor Federal Services

F. M. Mann (2)

R. J. Puigh (3)

Fluor Hanford

M. I. Wood

Pacific Northwest National Laboratory

M. P. Bergeron

Central files

From

SA\&NE

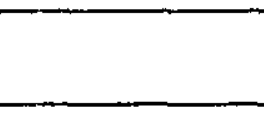

